\title{
Application of Frequency of Detection Methods in Design and Optimization of the INL Site Ambient Air Monitoring Network
}

Arthur S. Rood

A. Jeffrey Sondrup

November 2015

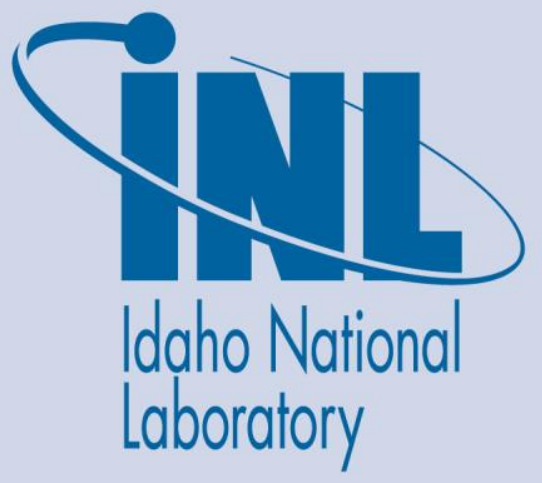

The INL is a U.S. Department of Energy National Laboratory operated by Battelle Energy Alliance 


\section{DISCLAIMER}

This information was prepared as an account of work sponsored by an agency of the U.S. Government. Neither the U.S. Government nor any agency thereof, nor any of their employees, makes any warranty, expressed or implied, or assumes any legal liability or responsibility for the accuracy, completeness, or usefulness, of any information, apparatus, product, or process disclosed, or represents that its use would not infringe privately owned rights. References herein to any specific commercial product, process, or service by trade name, trade mark, manufacturer, or otherwise, does not necessarily constitute or imply its endorsement, recommendation, or favoring by the U.S. Government or any agency thereof. The views and opinions of authors expressed herein do not necessarily state or reflect those of the U.S. Government or any agency thereof. 


\title{
Application of Frequency of Detection Methods in Design and Optimization of the INL Site Ambient Air Monitoring Network
}

\author{
Arthur S. Rood \\ A. Jeffrey Sondrup \\ November 2015 \\ Idaho National Laboratory \\ Idaho Falls, Idaho 83415 \\ http://www.inl.gov \\ Prepared for the \\ U.S. Department of Energy \\ DOE Idaho Operations Office
}





\title{
Application of Frequency of Detection Methods in Design and Optimization of the INL Site Ambient Air Monitoring Network
}

\author{
INL/EXT-15-36544
}

November 2015

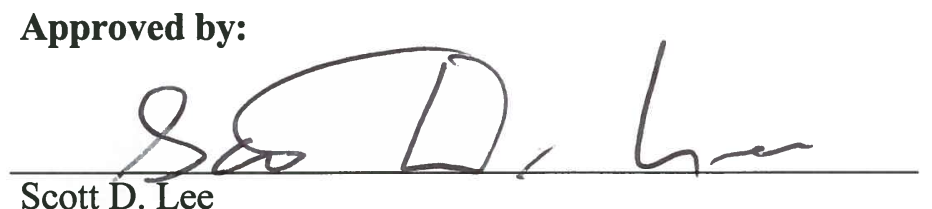

Scott D. Lee

Manager, Regulatory and Monitoring Services









\section{EXECUTIVE SUMMARY}

The Idaho National Laboratory (INL) maintains a network of ambient air samplers consisting of 37 low-volume air samplers at 31 locations that monitor atmospheric levels of radioactive particulates and radioiodine. Samples are analyzed for the purposes of (1) determining whether radiation doses to the public are within the limits established by U.S. Department of Energy (DOE) Order 458.1 (DOE 2011a), (2) evaluating background and INL Site contributions of radioactive material to the environment, and (3) providing documentation of ambient air concentrations in the event of a non-routine or unplanned release. The number and location of samplers that make up the ambient air monitoring network has evolved considerably since routine air monitoring began in the 1950s. Currently, samplers are located near each major onsite facility, at locations several miles from the facilities in the predominant wind directions, and in several distant locations, including the towns of Idaho Falls, Rexburg, and Blackfoot, Idaho; Jackson, Wyoming; and Craters of the Moon National Monument. Sampler placement is based on expert judgment, evaluation of meteorological data, and practical considerations such as the availability of power. The INL Site ambient air monitoring network conforms to the most recent DOE guidance (DOE 2015) and includes sampling stations beyond the minimum number required. However, guidance documents do not provide a means for evaluating the effectiveness of a network and there is no generally accepted method for quantitatively defining and evaluating the effectiveness of a surveillance network for a single source, let alone a network that covers multiple facilities (sources) and offsite sampler locations distributed over a large area and for releases that are not constant throughout the year.

This report presents an evaluation of a hypothetical INL Site monitoring network and the existing INL air monitoring network using frequency of detection methods. The hypothetical network was designed to address the requirement in 40 CFR Part 61, Subpart H (2006) that "emissions of radionuclides to ambient air from U.S. DOE facilities shall not exceed those amounts that would cause any member of the public to receive in any year an effective dose equivalent exceeding $10 \mathrm{mrem} /$ year." To meet the requirement for monitoring only, "radionuclide releases that would result in an effective dose of $10 \%$ of the standard shall be readily detectable and distinguishable from background." Thus, the hypothetical network consists of air samplers placed at residence locations that surround INL and at other locations where onsite livestock grazing takes place. Two exposure scenarios were used in this evaluation: a resident scenario and a shepherd/rancher scenario. The resident was assumed to be continuously present at their residence while the shepherd/rancher was assumed to be present 24-hours at a fixed location on the grazing allotment. Important radionuclides were identified from annual INL radionuclide National Emission Standards for Hazardous Pollutants reports. Important radionuclides were defined as those that potentially contribute $1 \%$ or greater to the annual total dose at the radionuclide National Emission Standards for Hazardous Pollutants maximally exposed individual location and include $\mathrm{H}-3, \mathrm{Am}-241, \mathrm{Pu}-238$, $\mathrm{Pu}-239$, Cs-137, Sr-90, and I-131. Release quantities of important radionuclides were determined so the maximum dose a resident would receive over a 1-week period (i.e., the sampling time) would be no greater than $0.0192 \mathrm{mrem}$ ( $1 \mathrm{mrem}$ if continuous over a year), and the maximum dose a shepherd/rancher would 
receive over a 24-hour period would be no greater than $1 \mathrm{mrem}$. Ninety-eight potential residence locations were identified near the INL Site boundary. Because many of the locations were relatively close to one another, this number was reduced to 27 unique locations. For the resident scenario, the hypothetical network assumed an air sampler at each of the 27 locations. The shepherd/rancher was assumed to be present on the grazing allotment boundary nearest to each INL facility (i.e., source). The hypothetical network for the shepherd/rancher scenario consisted of 16 air samplers distributed along 22.5-degree arcs surrounding each INL source at a radial distance equal to the minimum distance from the INL source to the grazing allotment boundary. Using release quantities determined for the hypothetical network, the existing INL network was also evaluated.

The frequency of detection methodology is documented in Rood and Sondrup (2014). Frequency of detection is defined as the fraction of "events" that result in detection at either a single sampler or network of samplers. An "event" is defined as a release of finite duration that begins on a given day and hour of the year. The frequency of detection ranges from zero (no detections) to 1.0 (100\% detection). For example, a network frequency of detection of 0.9 means that, during $90 \%$ of the time period simulated, the release will be detected by a sampler in the network and $10 \%$ of the time the release will go undetected in the network. Frequency of detection can use any length time of meteorological data, but at least 1-year of meteorological data is recommended and was used for this assessment. The methodology also requires an atmospheric transport model to calculate unit time-integrated concentrations at sampler locations from source releases. Two atmospheric transport models were used in this assessment. The CALPUFF Lagrangian puff model was used to evaluate the hypothetical network for the resident scenario and the existing INL monitoring network. A Gaussian plume model was used to evaluate the hypothetical network for the shepherd/rancher scenario. The Gaussian plume model was used for the shepherd/rancher scenario because transport distances from INL sources to the receptor locations (i.e., nearest grazing allotment boundary) were less than $10 \mathrm{~km}$.

For this evaluation, the network performance objective was set at achieving a frequency of detection greater than or equal to $95 \%$. Results indicated that the hypothetical network for the resident scenario met all performance objectives for H-3 and I-131 and most performance objectives for Cs-137 and Sr-90. However, all actinides failed to meet the performance objectives for most sources. The shepherd/rancher scenario showed that air samplers placed around the facilities every 22.5 degrees were very effective in detecting releases, but this arrangement is not practical or cost effective. However, it was shown that a few air samplers placed in the prevailing wind direction around each facility could achieve the performance objective of a frequency of detection greater than or equal to $95 \%$ for the shepherd/rancher scenario.

Using the release quantities determined for the hypothetical sampling network for the resident and shepherd/rancher scenario, performance of the existing INL air monitoring network was evaluated. Performance objectives were met for all sources for the resident scenario. Performance objectives were met for the shepherd/rancher scenario for all sources except the Materials and Fuels Complex source (i.e., MFC-764 stack), because the sampler near the Materials and Fuels Complex facility is not located in the prevailing wind direction from 
the facility. The results also indicate some of the current sampler locations have little or no impact on the network frequency of detection and could be removed from the network with no appreciable deterioration of performance. Results show that with some slight modifications to the existing network (i.e., additional samplers added north and south of the Materials and Fuels Complex and ineffective samplers removed), the network would achieve performance objectives for all sources for both the resident and shepherd/rancher scenario. 


\section{CONTENTS}

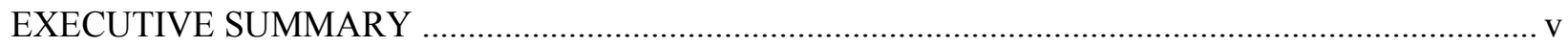

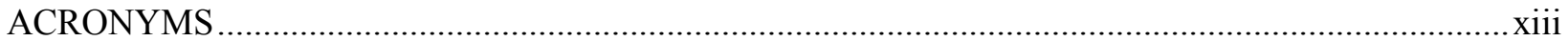

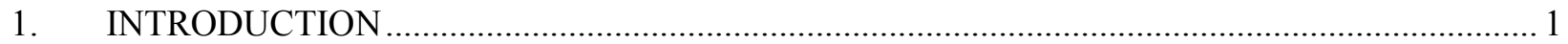

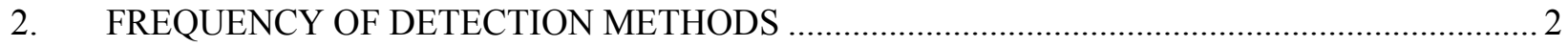

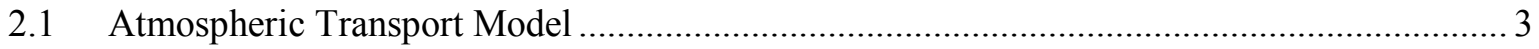

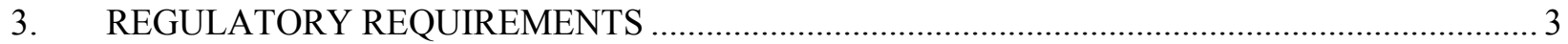

4. EXISTING IDAHO NATIONAL LABORATORY SITE AMBIENT AIR

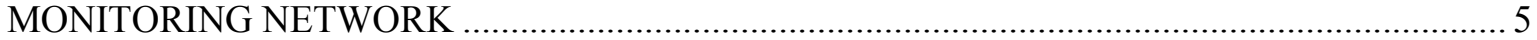

5. IDAHO NATIONAL LABORATORY EMISSION SOURCES ............................................... 7

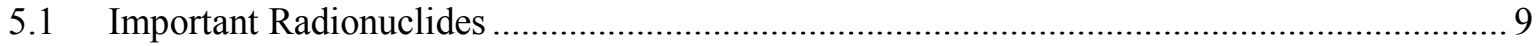

6. DESIGN OF AN AIR MONITORING NETWORK ......................................................... 10

6.1 Idaho National Laboratory Receptor/Exposure Scenarios .............................................. 10



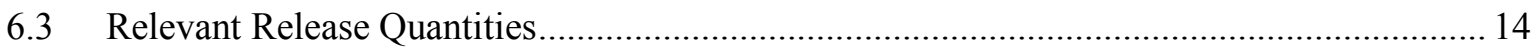

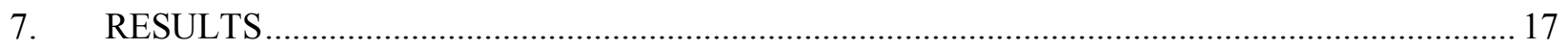

7.1 Frequency of Detection Results for Hypothetical Network ............................................. 17

7.2 Frequency of Detection Results for the Existing Network ............................................. 19

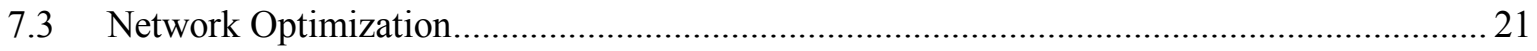

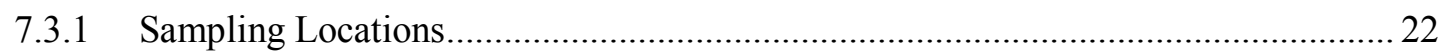

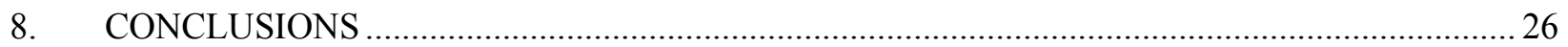

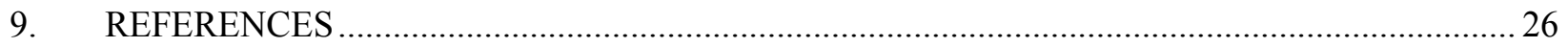

\section{FIGURES}

1. INL Site ambient air monitoring network sampler locations …….......................................

2. INL major facility source locations. TRA-770, CPP-708, and MFC-764 are stack release locations. All other sources are modeled as ground-level releases. 
3. The 98 resident receptor locations identified by ESER (i.e., black dots) and the 27 resident receptor locations used in the model (yellow circles that are numbered 1 through 27)

4. FD for a hypothetical network consisting of 16 samplers encircling the facility for the shepherd/rancher scenario

5. Contour plot of the annual average dispersion factor (or $\mathrm{X} / \mathrm{Q}$ in $\mathrm{s} / \mathrm{m}^{3}$ ) for a steady-state release from the MFC-764 stack.

6. FD versus azimuth for Am-241 released from the MFC-764 stack over a 24-hour period

\section{TABLES}

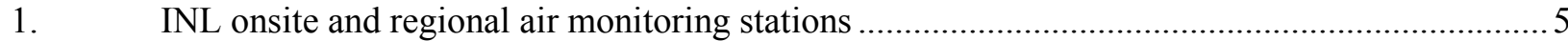

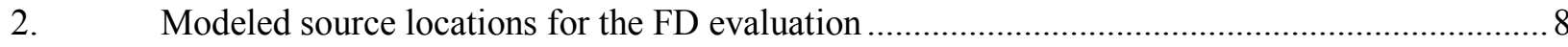

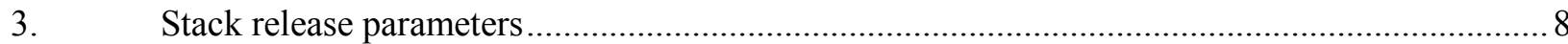

4. Radionuclides important in terms of radiological dose based on the 2007 to 2013 INL

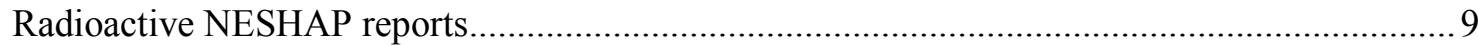

5. UTM coordinates of the 27 potential resident receptor locations used in the model................. 11

6. Distance from each INL facility to the nearest grazing allotment boundary for the shepherd/rancher scenario

7. Unit dose factors, APDCs, and inhalation dose coefficients for the important radionuclides at the INL Site

8. Radionuclide MDA values, TIC values that yield dose limits, and activity accumulated on filters for the given TIC value

9. Release quantities (pCi) that would result in a maximum weekly dose of 0.0192 mrem (equivalent to $1 \mathrm{mrem} /$ year if continuous over a year) at a residence location

10. Release quantities (pCi) that would result in a maximum 24-hour dose of 1.0 mrem at the nearest distance to a grazing allotment from an INL Site facility

11. Location of reference resident for a 168-hour release (i.e., 1-week) that results in $0.0192 \mathrm{mrem}$ (1.0 mrem/year)

12. Azimuth and distance from INL Site facilities that results in a maximum dose of 1mrem for a 24-hour release (i.e., 1-day) for the shepherd/rancher scenario

13. Network FD and intensity for a hypothetical sampling network consisting of samplers at each of the 27 resident locations for the resident scenario 
14. Network FD and intensity for the 16 hypothetical samplers surrounding the facility at a distance equal to the nearest grazing allotment boundary for the shepherd/rancher scenario

15. Network FD and intensity for the existing INL Site sampling network consisting of 36 samplers for the resident scenario.

16. Network FD and intensity for the existing INL Site sampling network consisting of 36 samplers for the shepherd/rancher scenario

17. Network FD and intensity for the optimized INL Site sampling network and the shepherd/rancher scenario for a 24 -hour release .

18. Percent change in network FD and intensity from the optimized and existing network 


\section{ACRONYMS}

ASER Annual Site Environmental Report

APDC all-pathway dose coefficient

ATR

Advanced Test Reactor

BEA

Battelle Energy Alliance, LLC

CFA Central Facilities Area

cfm cubic feet per minute

CITRC Critical Infrastructure Test Range Complex

DOE U.S. Department of Energy

DOE-ID U.S. Department of Energy, Idaho Operations Office

ESER Environmental Surveillance, Education, and Research (Program)

FAA Federal Aviation Administration

FD frequency of detection

INL Idaho National Laboratory

INTEC Idaho Nuclear Technology and Engineering Center

MDA minimum detectable activity

MEI maximally exposed individual

MFC Material and Fuels Complex

NESHAP National Emission Standards for Hazardous Air Pollutants

NRF Naval Reactors Facility

RWMC Radioactive Waste Management Complex

SMC Specific Manufacturing Capability

TAN Test Area North

TIC time-integrated concentration

UTM Universal Transverse Mercator 


\section{Application of Frequency of Detection Methods in Design and Optimization of the INL Site Ambient Air Monitoring Network}

\section{INTRODUCTION}

Airborne radionuclide emissions at the Idaho National Laboratory (INL) Site are generated from various facilities during operations and scientific research activities. Engineering and administrative controls are implemented to prevent, reduce, and/or eliminate these emissions from the environment. The INL Site performs facility emissions and ambient air surveillance monitoring to assess the adequacy of these controls in protecting human health and determining environmental impacts. The basis for INL Site air monitoring activities is documented in the report Technical Basis for Environmental Monitoring and Surveillance at the Idaho National Laboratory (DOE-ID 2014a), which summarizes ambient air and other monitoring conducted at the INL Site and surrounding area to meet the requirements and criteria set forth in U.S. Department of Energy (DOE) Order 458.1, "Radiation Protection of the Public and the Environment," (DOE 2011a) and the DOE Handbook-Environmental Regulatory Guide for Radiological Effluent Monitoring and Environmental Surveillance (DOE 2015), as well as address environmental risks and stakeholder concerns.

A primary component of the INL Site ambient air monitoring program is a network of low-volume air samplers that monitor atmospheric levels of radioactive particulates and radioiodine released from INL Site facilities, natural radioactivity (i.e., radon and daughters), and fallout from worldwide nuclear detonations or nuclear accidents. Samples are analyzed for the purposes of (1) determining whether radiation doses to the public are within the limits established in DOE Order 458.1 (DOE 2011a), (2) evaluating background and INL Site contributions of radioactive material to the environment, and (3) providing documentation of ambient air concentrations in the event of a non-routine or unplanned release. The number and location of samplers that make up the ambient air monitoring network has evolved considerably since routine air monitoring began in the 1950s. Air samplers have typically been placed at facilities with significant radiological sources, at offsite locations most likely to be most impacted by emissions, background locations, and at locations chosen to help characterize ground-level concentrations between the source and populated areas. Currently, samplers are located near each major onsite facility, at locations in the predominant wind directions several miles from the facilities, and in several distant locations, including the towns of Idaho Falls, Rexburg, and Blackfoot, Idaho; Jackson, Wyoming; and Craters of the Moon National Monument west of Arco, Idaho. These sampler locations meet program goals and are based on expert judgment that includes evaluation of meteorological data, air dispersion modeling, and practical considerations such as the availability of power. DOE-ID (2014a) provides a complete description of the air monitoring program.

Although several of the current sampler locations were selected before the first guidance document (EPA 1972) was released, the INL Site's ambient air monitoring network conforms to the most recent guidance (DOE 2015) and includes sampling stations beyond the minimum number required. Nevertheless, guidance documents do not provide a means for evaluating the effectiveness of a network and there is no generally accepted method for quantitatively defining and evaluating the effectiveness of a surveillance network for a single source, let alone a network that covers facilities and offsite locations distributed over a large area.

This report documents application of frequency of detection (FD) methods in the design and optimization of the INL Site ambient air monitoring network. Optimization here means identifying a set of samplers that achieves FD performance objectives and identifying samplers that have low FD or are redundant. FD methods described and demonstrated in Rood and Sondrup (2014) are summarized first, followed by a discussion of regulatory requirements for air monitoring networks, presentation of the 
existing INL Site air monitoring network, and an inventory of INL Site radioactive release sources. Next, a hypothetical air monitoring network design that addresses the regulatory requirements is presented. Identification of important radionuclides and calculation of release quantities that would result in regulatory dose constraints being met are presented. Using these calculated release quantities, a conceptual network and the existing INL Site air monitoring network are evaluated in terms of FD. Finally, changes that could be made to the existing air monitoring network to improve performance are evaluated and presented.

\section{FREQUENCY OF DETECTION METHODS}

Rood and Sondrup (2014) developed a methodology and modeling tool that can be used to objectively and quantitatively assess an air monitoring network design against established performance metrics and objectives. The methodology utilizes an atmospheric transport model to simulate hypothetical releases of radionuclides from major INL facilities and calculate time-integrated concentrations at potential receptor locations.

The performance metric is the FD, which is defined as the fraction of "events" that result in detection at either a single sampler or network of samplers. An "event" is defined as a release of finite duration that begins on a given day and hour of the year. Assuming a single source is emitting radionuclides into the atmosphere, FD is defined as:

$F D_{r, s}=\frac{\sum_{k=1}^{N} f\left(D_{r, s, k}\right)}{N}$

where

$$
\begin{aligned}
& f\left(D_{r, s, k}\right)=\text { a binary function that returns } 1 \text { if the detection }\left(D_{r, s, k}\right) \text { is true and } 0 \text { if it is false for } \\
& \text { radionuclide } r \text { at sampler } s \text { and event } k, \\
& N=\text { the number of "events." }
\end{aligned}
$$

The number of events is the number of release periods simulated in the assessment and depends on the number of hours of meteorological data present. For example, 8,761 hours of meteorological data are needed to model 8,760 1-hour events. Likewise, 8,784 hours of meteorological data are needed to model 8,760 24-hour events. A "detection" $\left(D_{r, s, k}\right)$ is defined in terms of the radionuclide $(r)$, the sampler $(s)$, and the event $(k)$. Detection is either true or false (i.e., either the sampler can detect the activity collected from airborne sampling or it cannot detect the activity). Detection is assigned a true value if the following condition is met:

$$
T I C_{r, s, Q, T r} \times F \geq M D A_{r}
$$

where

$$
\begin{aligned}
& T I C_{r, S, Q, T r}=\text { time-integrated concentration for radionuclide } r \text { at sampler } s \text { for release quantity } Q, \\
& \text { release duration } T r \text {, and sampling time } T s\left(\mathrm{Ci}-\mathrm{hr} \mathrm{m}^{-3}\right) \\
& F=\text { the sampler flow rate }\left(\mathrm{m}^{3} \mathrm{hr}^{-1}\right) \\
& M D A_{r}=\text { minimum detectable activity for radionuclide } r(\mathrm{Ci}) .
\end{aligned}
$$

An atmospheric transport model is used to compute the time-integrated concentrations (TICs) at each of the samplers for radionuclide $r$, release quantity $Q$, and release duration $T r$. The TIC is calculated by integrating the concentration at the sampler over the sampling time (Ts). 


$$
T I C_{r, s, Q, T r}=\int_{0}^{T s} C_{r, s, Q, T r}(t) d t
$$

where

$$
\begin{aligned}
& C_{r, s, Q, T r}(t)=\text { concentration as a function of time for radionuclide } r \text { at sampler } s \text {, release quantity } Q \text {, } \\
& \text { and release duration } \operatorname{Tr}\left(\mathrm{Ci} \mathrm{m}^{-3}\right) \text {. }
\end{aligned}
$$

Input to the FD model includes unit-activity TICs at discrete sampler locations (either real or hypothetical), sampler flow rates, sampling times, release quantities, release durations, and minimum detectable activity (MDA) levels. The unit-activity TICs are the time-integrated concentrations divided by the release quantities $\left(\mathrm{hr} \mathrm{m}^{-3}\right)$ and are determined from the atmospheric transport model discussed in the next subsection. Using these data, the model calculates the FD for each sampler location and the network as a whole. The model steps through each hour of the year (i.e., each event), releasing the activity over the release time and calculating the FD for both individual samplers and the network of samplers.

The FD ranges from zero (i.e., no detections) to 1.0 (i.e., 100\% detection). For example, a network FD of 0.9 means that, during $90 \%$ of the period simulated, the release will be detected by the network and $10 \%$ of the time the release will go undetected in the network. Performance objectives of the network or an individual sampler are defined by an acceptable FD.

Another quantity of interest is network intensity. Network intensity is the fraction of samplers in the network that would have positive detection. For example, if all detections from a release originate from a single sampler in the network, then intensity will be low. However, if the release is detected by multiple samplers in the network, then network intensity will be relatively high. A high intensity could indicate unnecessary redundancy in the network. Intensity is given by

$$
I_{r, n w}=\frac{\sum_{k=1}^{N} \sum_{s=1}^{n w} f\left(D_{r, s, k}\right)}{N \times n w}
$$

where

$$
\begin{aligned}
& \mathrm{f}(\mathrm{Dr}, \mathrm{s}, \mathrm{k})=\quad \text { a binary function that returns } 1 \text { if the detection }(\mathrm{Dr}, \mathrm{s}, \mathrm{k}) \text { is true and } 0 \text { if it is false for } \\
& \text { radionuclide } \mathrm{r} \text { at sampler s and event } \mathrm{k}
\end{aligned}
$$

\subsection{Atmospheric Transport Model}

The FD methodology requires an atmospheric transport model to calculate TICs at samplers for releases from individual sources. Two atmospheric transport models were used in this assessment. The primary model used in the FD calculations was the CALPUFF model (Scire et al. 2000a, 2000b). Details of the CALPUFF model simulation, including meteorological data, input parameter selection, and model verification and validation, are provided in Rood and Sondrup (2014). This model was used to calculate FD values at INL network samplers and residential receptor locations for releases from INL Site sources. The second model was a straight-line Gaussian plume model (Appendix A). This model was used to calculate FD values for hypothetical samplers near INL Site sources.

\section{REGULATORY REQUIREMENTS}

Because radiological releases from INL Site operations and scientific research activities have the potential to impact human health and the environment, DOE Order 458.1 (DOE 2011) states the following: 
Environmental monitoring must be conducted to characterize routine and non-routine releases of radioactive material from radiological activities, estimate the dispersal pattern in the environs, characterize the pathway(s) of exposure to members of the public, and estimate the doses to individuals and populations in the vicinity of the site or operation commensurate with the nature of the DOE radiological activities and the risk to the public and the environment.

The DOE Handbook-Environmental Radiological Effluent Monitoring and Environmental Surveillance (DOE 2015) was developed to assist in establishment and maintenance of effective environmental monitoring activities, which includes effluent monitoring, environmental surveillance, meteorological monitoring, and pre-operational monitoring. In the case of environmental surveillance, the DOE Handbook assists in characterization of the environs around DOE activities and supports assessment of potential public exposure through available pathways (e.g., air, water, soil, and biota).

The minimum criteria for determining the need for environmental surveillance is provided in Table 6-1 of the DOE Handbook (DOE 2015). According to these criteria, measurements or provisions for detection should be made for the following:

- Unplanned releases of radionuclides to the environment

- Characterization of background

- Pathway measurements (i.e., actual measurements on two media for each critical radionuclide/pathway combination)

- Routine surveillance of all pathways (i.e., ingestion, inhalation, and immersion doses) -or-

- Periodic confirmation of potential doses.

The criteria state that routine surveillance of all pathways should be conducted if the annual dose at the site of the hypothetical maximally exposed individual (MEI) might exceed 5-mrem effective dose or 100 person-rem collective effective dose with a radius of $80 \mathrm{~km}$ in a year. Periodic measurements are recommended at $20 \%$ of the reference dose (e.g., 1 mrem per year) or if biota screening levels are challenged.

Recent dose calculations for the INL Site resulted in a dose to the MEI less than $0.1 \mathrm{mrem} / \mathrm{year}$ and less than 0.5 person-rem for the 50-mile population (DOE-ID 2014b). Moreover, biota screening levels have not been exceeded based on recent calculations (DOE-ID 2014b).

Other requirements outlined in 40 CFR Part 61, Subpart H, "National Emission Standards for Emissions of Radionuclides Other than Radon from Department of Energy Facilities," (2006) state that "emissions of radionuclides to ambient air from U.S. Department of Energy facilities shall not exceed those amounts that would cause any member of the public to receive in any year an effective dose equivalent exceeding $10 \mathrm{mrem} /$ year." To meet the requirement for monitoring only, "radionuclide releases that would result in an effective dose of $10 \%$ of the standard shall be readily detectable and distinguishable from background." Therefore, radionuclide concentrations at receptor locations that would result in $1 \mathrm{mrem} /$ year would need to be readily detectable and distinguishable from background.

In the interest of adhering to the As Low As Reasonably Achievable safety principles and to ensure detection of INL Site releases well before dose standards are approached, the objective of the INL Site monitoring program is to determine whether the air surveillance network meets the requirements of being able to detect radioactive air emissions resulting in a dose to the MEI of greater than or equal to $1.0 \mathrm{mrem} /$ year or $10 \%$ of the 40 CFR Part 61, Subpart H (2010) dose limit. This ensures protection of the public and the environment. 


\section{EXISTING IDAHO NATIONAL LABORATORY SITE AMBIENT AIR MONITORING NETWORK}

The INL Site ambient air monitoring network (see Table 1 and Figure 1) consists of 37 low-volume air samplers in 31 different locations. Twenty-one samplers with the Battelle Energy Alliance (BEA) prefix are maintained and sampled by the INL Site contractor, BEA, and 16 samplers with the Environmental Surveillance, Education, and Research (ESER) prefix are maintained and sampled by Gonzales-Stoller Surveillance for the ESER Program. The network does not include miscellaneous air samplers maintained and sampled by the INL Site cleanup contractor CH2M-WG Idaho, LLC. BEA and Gonzales-Stoller Surveillance have collocated samplers at Craters of the Moon National Park, Sugar City, Blackfoot, Idaho Falls, Van Buren Avenue (near Highway 20/26), and the Experimental Field Station, which is located northeast of the Idaho Nuclear Technology and Engineering Center (INTEC).

FRENCHCBN (Frenchman's Cabin) is not a sampler location, but it is included because it is the MEI location for the INL radionuclide National Emission Standard for Hazardous Air Pollutants (NESHAP) analysis and it is used to determine appropriate source release quantities for this assessment. Table 1 also indicates whether the sampler is located within the INL Site boundary.

The low-volume air samplers are configured with particulate filters for collection of particulate radionuclides and charcoal filter cartridges for collection of I-131. The samplers run continuously (i.e., 24/7) and particulate filters are collected weekly and analyzed for gross-alpha and gross-beta activity. The filters are also composited quarterly (every 13 weeks) and analyzed for gamma-emitting radionuclides. Selected ESER sample composites are analyzed for Sr-90, Cs-137, and actinides (i.e., $\mathrm{Pu}-238, \mathrm{Pu}-239 / 240$, and $\mathrm{Am}-241$ ) each quarter on a rotating basis. BEA screens for these radionuclides using gross-alpha/beta activity and gamma analyses and requests additional radionuclide-specific analyses if results are anomalous. The average flow rate of the samplers between weekly collections is approximately $2 \mathrm{cfm}$.

Tritium is monitored at five of the locations identified in Table 1 . The sampler flow is $19 \mathrm{~L} /$ hour. The sampler is run until about $50 \mathrm{~mL}$ of water is collected from moisture in the air. Based on an annual average absolute humidity of $3.45 \mathrm{mg} / \mathrm{L}$, a 27 -day sampler run time is necessary to collect $50 \mathrm{~mL}$ of water. A 9-mL aliquot is analyzed for tritium.

Air monitoring network parameters needed for the FD analysis include the sampler flow rate, sampler run time, and radionuclide MDA. Other parameters not specific to the air monitors include release time, release duration, and release quantity.

Table 1. INL onsite and regional air monitoring stations.

\begin{tabular}{|c|c|c|c|c|c|}
\hline Sampler ID ${ }^{\mathrm{a}}$ & Location/Description & $\begin{array}{l}\text { Easting }^{\mathrm{b}} \\
(\mathrm{m})\end{array}$ & $\begin{array}{l}\text { Northing }{ }^{\mathrm{b}} \\
(\mathrm{m})\end{array}$ & $\begin{array}{c}\text { INL } \\
\text { Onsite }\end{array}$ & Tritium? \\
\hline BEA-ARA & Auxiliary Reactor Area & 352512 & 4820236 & Yes & \\
\hline BEA-BLKFT & Blackfoot & 391668 & 4782760 & No & Yes \\
\hline BEA-CFA & Central Facilities Area (CFA) & 342602 & 4821788 & Yes & \\
\hline BEA-CPP & INTEC & 343508 & 4825928 & Yes & \\
\hline BEA-CRATERS & Craters of the Moon National Park & 292750 & 4815337 & No & \\
\hline BEA-EBR-I & Experimental Breeder Reactor-I & 337858 & 4819578 & Yes & \\
\hline BEA-EFS & Experimental Field Station & 346110 & 4829754 & Yes & \\
\hline BEA-GATE 4 & Gate 4 entrance near Test Area North & 358520 & 4848895 & Yes & \\
\hline BEA-IF & Idaho Falls & 414380 & 4818193 & No & \\
\hline BEA-INTEC & INTEC & 344158 & 4826806 & Yes & \\
\hline BEA-IRC & INL Research Center (Idaho Falls) & 416371 & 4818572 & No & \\
\hline BEA-MFC & Materials and Fuels Complex (MFC) & 366673 & 4828121 & Yes & \\
\hline
\end{tabular}




\begin{tabular}{|c|c|c|c|c|c|}
\hline Sampler ID ${ }^{\mathrm{a}}$ & Location/Description & $\begin{array}{l}\text { Easting }^{\mathrm{b}} \\
(\mathrm{m})\end{array}$ & $\begin{array}{l}\text { Northing }{ }^{\mathrm{b}} \\
(\mathrm{m})\end{array}$ & $\begin{array}{l}\text { INL } \\
\text { Onsite }\end{array}$ & Tritium? \\
\hline BEA-NRF & Naval Reactors Facility (NRF) & 345564 & 4834400 & Yes & \\
\hline BEA-PBF & $\begin{array}{l}\text { Critical Infrastructure Test Range Complex } \\
\text { (CITRC) }\end{array}$ & 348964 & 4823313 & Yes & \\
\hline BEA-REST & Rest Stop on Highway 20 & 337640 & 4823710 & Yes & \\
\hline BEA-RTC & Advanced Test Reactor (ATR) Complex & 341727 & 4828168 & Yes & \\
\hline BEA-RWMC & Radioactive Waste Management Complex (RWMC) & 335063 & 4818552 & Yes & \\
\hline BEA-SMC & Specific Manufacturing Capability (SMC) Facility & 360950 & 4857753 & Yes & \\
\hline BEA-SUGAR & Sugar City, Rexburg & 440759 & 4860651 & No & \\
\hline BEA-TRA & ATR Complex & 341316 & 4827516 & Yes & \\
\hline BEA-VAN B & Van Buren Boulevard & 339762 & 4822063 & Yes & \\
\hline ESER-ARC & Arco & 314683 & 4832742 & No & \\
\hline ESER-ATO & Atomic City & 353080 & 4811691 & No & Yes \\
\hline ESER-BLU & Blue Dome & 352495 & 4881840 & No & \\
\hline ESER-CRA & Craters of the Moon National Park & 292751 & 4815337 & No & Yes \\
\hline ESER-DUB & Dubois & 401640 & 4892296 & No & \\
\hline ESER-EFS & Experimental Field Station & 346114 & 4829752 & Yes & Yes \\
\hline ESER-FAA & $\begin{array}{l}\text { Federal Aviation Administration (FAA) Tower near } \\
\text { east boundary of INL }\end{array}$ & 375764 & 4823554 & Yes & \\
\hline ESER-HOW & Howe & 340891 & 4849795 & No & \\
\hline ESER-IDA & Idaho Falls & 414376 & 4818192 & No & Yes \\
\hline ESER-JAC & Jackson Hole (outside domain) & 519314 & 4813939 & No & \\
\hline ESER-MAI & INL Main Gate & 346614 & 4819341 & Yes & \\
\hline ESER-MON & Monteview & 376885 & 4874727 & No & \\
\hline ESER-MOU & Mountain View Middle School, Blackfoot & 391668 & 4782752 & No & \\
\hline ESER-SUG & Sugar City/Rexburg & 440759 & 4860651 & No & \\
\hline ESER-TER & Terreton/Mud Lake & 381307 & 4855032 & No & \\
\hline ESER-VAN & Van Buren Boulevard & 339764 & 4822062 & Yes & \\
\hline FRENCHCBN $^{\mathrm{c}}$ & Frenchman's Cabin (INL MEI location) & 333548 & 4810289 & No & \\
\hline
\end{tabular}

a. Samplers with the BEA prefix are sampled and maintained by BEA. Samplers with the ESER prefix are sampled and maintained by the ESER Program.

b. Universal Transverse Mercator (UTM) coordinate system (Zone 12).

c. Frenchman's Cabin is not a sampler location, but it is the MEI location for 40 CFR 61, Subpart H (NESHAP) compliance. 


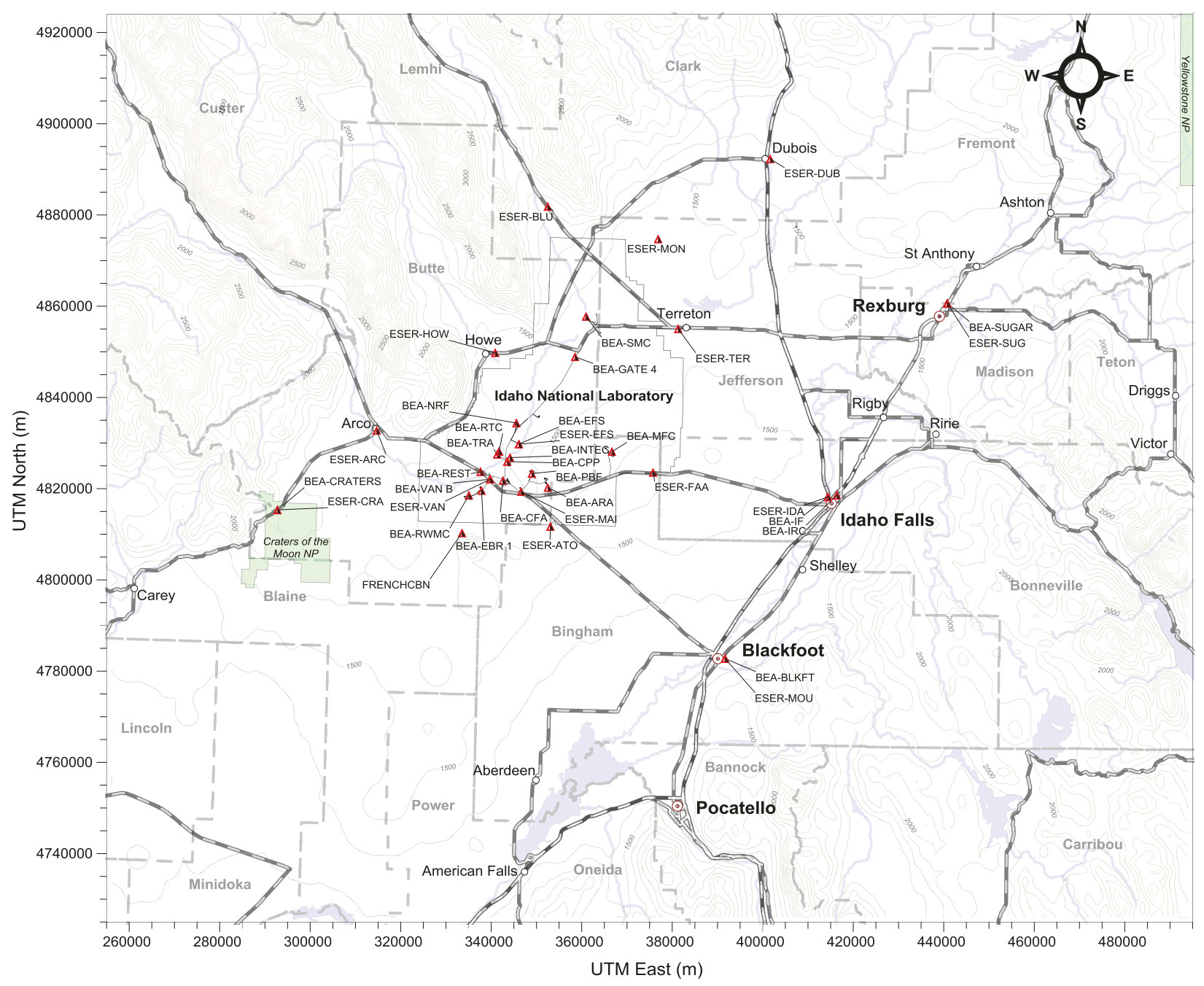

Figure 1. INL Site ambient air monitoring network sampler locations. There is no sampler located at FRENCHCBN (Frenchman's Cabin), but it is included because it is the MEI for the INL NESHAPs analysis. The ESER-JAC sampler in Jackson, Wyoming is not shown. The entire area is also the atmospheric transport model domain discussed in Section 2.1.

\section{IDAHO NATIONAL LABORATORY EMISSION SOURCES}

For the preliminary assessment of the INL Site monitoring network and demonstration of the FD methodology (Rood and Sondrup 2014), sources were defined at each of the major INL Site facilities (Table 2Error! Reference source not found.). The 2013 INL NESHAPs evaluation (DOE-ID 2014b) reported potential radionuclide releases from more than 60 source locations at the INL Site. However, many of the sources resulted in doses that were insignificant and many sources are located relatively close together such that the sampling network response from a release would be the same for all nearby sources. Therefore, insignificant sources were not explicitly modeled and some sources were consolidated with nearby sources. The large operating stacks were modeled explicitly and included the ATR main stack (TRA-770), the INTEC main stack (CPP-708), and the Experimental Breeder Reactor-II main stack (MFC-764). The materials test reactor stack (TRA-710) was not modeled due to its close proximity to the ATR main stack and because releases from the materials test reactor stack are significantly less than the ATR stack. Stack parameters are provided in Table 3. All other releases within a facility were assigned as ground-level releases from a single location within the facility. These other releases include other non- 
fugitive releases from ducts and vents and fugitive releases from ponds, soil, or other. The ground-level release location for a facility was assigned to the most significant source (in terms of activity released) based on the 2013 NESHAPs evaluation (DOE-ID 2014b) or, if there were multiple significant sources, it was assigned to a location near the center of the facility. Figure 2 shows the location of all sources modeled in this study.

Table 2. Modeled source locations for the FD evaluation.

\begin{tabular}{|c|c|c|c|c|c|}
\hline Facility & Source & $\begin{array}{l}\text { Release } \\
\text { Type }\end{array}$ & Source Description & $\begin{array}{l}\text { Easting }^{\mathrm{a}} \\
(\mathrm{m})\end{array}$ & $\begin{array}{l}\text { Northing }{ }^{a} \\
(\mathrm{~m})\end{array}$ \\
\hline $\begin{array}{l}\text { ATR } \\
\text { Complex }\end{array}$ & TRA-770 & Stack & ATR Stack & 341206 & 4828106 \\
\hline INTEC & СРP-708 & Stack & INTEC Main Stack & 343862 & 4826156 \\
\hline MFC & MFC-764 & Stack & $\begin{array}{l}\text { Experimental Breeder Reactor-II } \\
\text { Main Stack }\end{array}$ & 366326 & 4828209 \\
\hline $\begin{array}{l}\text { ATR } \\
\text { Complex }\end{array}$ & Center & Ground & Near center of ATR Complex & 341401 & 4827855 \\
\hline CFA & CFA-625 & Ground & Lab fume hoods (near center of CFA) & 343271 & 4821432 \\
\hline CITRC & PBF-632 & Ground & $\begin{array}{l}\text { Waste Reduction Operations Complex } \\
\text { support building vent }\end{array}$ & 349099 & 4823351 \\
\hline INTEC & CPP-1774 & Ground & $\begin{array}{l}\text { Three Mile Island- } 2 \text { Spent Fuel } \\
\text { Storage Installation (near center of } \\
\text { INTEC) }\end{array}$ & 343831 & 4825808 \\
\hline MFC & MFC-774 & Ground & $\begin{array}{l}\text { Zero Power Physics Reactor Support } \\
\text { Wing (south center of MFC) }\end{array}$ & 366389 & 4828004 \\
\hline NRF & Center & Ground & Near center of NRF & 345498 & 4834667 \\
\hline RWMC & Center & Ground & Near center of RWMC & 334818 & 4818274 \\
\hline SMC/TAN & TAN-679 & Ground & $\begin{array}{l}\text { SMC Manufacturing and Assembly } \\
\text { Building }\end{array}$ & 360856 & 4857565 \\
\hline
\end{tabular}

a. UTM coordinate system, North American Datum 1983.

Table 3. Stack release parameters.

\begin{tabular}{llcccc}
\hline \multicolumn{1}{c}{ Facility } & Source Stack & $\begin{array}{c}\text { Stack Height } \\
(\mathrm{m})\end{array}$ & $\begin{array}{c}\text { Exit Diameter } \\
(\mathrm{m})\end{array}$ & $\begin{array}{c}\text { Exit Velocity }^{\mathrm{a}} \\
\left(\mathrm{m} \mathrm{s}^{-1}\right)\end{array}$ & $\begin{array}{c}\text { Flow Rate }^{\mathrm{a}} \\
(\mathrm{cfm})\end{array}$ \\
\hline ATR Complex & TRA-770 & 76.2 & 1.524 & 10.03 & 38,776 \\
INTEC & CPP-708 & 76.2 & 1.83 & 10.65 & 59,370 \\
MFC & MFC-764 & 60 & 1.524 & 9.081 & 35,100 \\
\hline
\end{tabular}

a. Flow rates and exit velocities based on average 2013 values. 


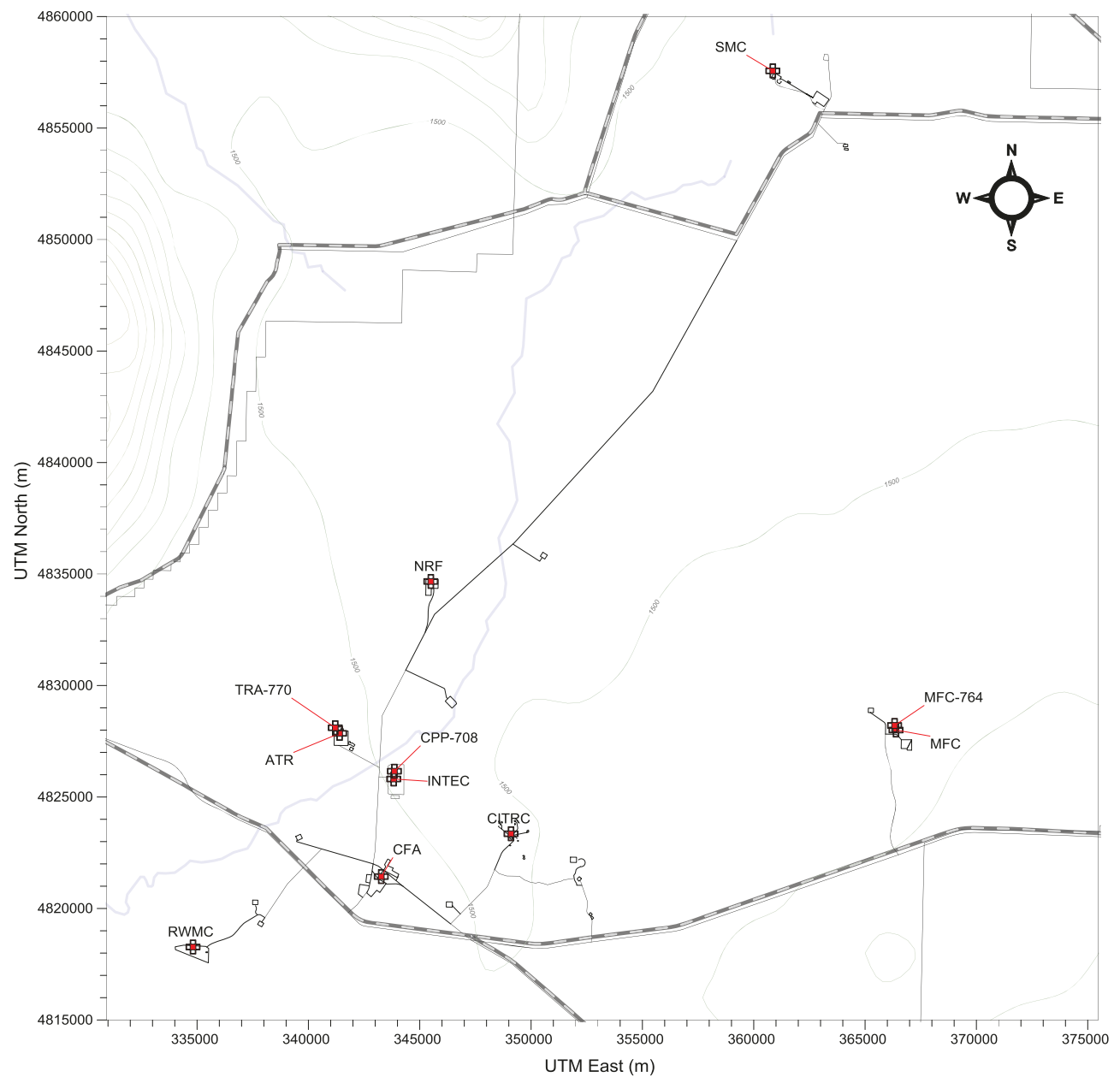

Figure 2. INL major facility source locations. TRA-770, CPP-708, and MFC-764 are stack release locations. All other sources are modeled as ground-level releases.

\subsection{Important Radionuclides}

Radionuclides used for calculating FD and intensity values were determined by their dose potential based on recent INL radionuclide NESHAPs analyses. Radionuclide-specific estimated doses from the 2007 to 2013 annual INL radionuclide NESHAPs reports were compiled. Eight radionuclides that contributed at least $1 \%$ or greater to the total dose were identified (Table 4). Argon-41 represented 7.22\% of the total dose, but it is not monitored for because it is a noble gas. Iodine- 129 represented $4.54 \%$ of the total dose, but it is also not monitored for because it is difficult to detect. For these reasons, I-129 and Ar-41 are not included in the list of important radionuclides. Although I-131 represented only $0.03 \%$ of the total dose, it is routinely monitored for and can be an important radionuclide in reactor effluent, especially during accidents. For these reasons, I-131 was included in the list of important radionuclides. Thus, the important radionuclides are H-3, Pu-239/240, Pu-238, Cs-137, Sr-90, Am-241, and I-131.

Table 1. Radionuclides important in terms of radiological dose based on the 2007 to 2013 INL Radioactive NESHAP reports.

\begin{tabular}{cc}
\hline Radionuclide $^{\mathrm{a}}$ & Percent of Total Dose 2007 through 2013 \\
\hline H-3 (vapor) & $25.22 \%$ \\
Pu-239/240 & $19.78 \%$ \\
Cs-137 & $18.13 \%$
\end{tabular}




\begin{tabular}{cc}
\hline Radionuclide $^{\mathrm{a}}$ & Percent of Total Dose 2007 through 2013 \\
\hline Sr-90 & $12.49 \%$ \\
Am-241 & $8.20 \%$ \\
Ar-41 (gas) & $7.22 \%$ \\
I-129 & $4.54 \%$ \\
Pu-238 & $1.51 \%$ \\
C-14 & $0.59 \%$ \\
Co-60 & $0.58 \%$ \\
Am-243 & $0.45 \%$ \\
Pu-241 & $0.42 \%$ \\
Kr-88 (gas) & $0.19 \%$ \\
Xe-138 (gas) & $0.18 \%$ \\
Kr-85 (gas) & $0.11 \%$ \\
Kr-87 (gas) & $0.06 \%$ \\
Cm-244 & $0.05 \%$ \\
Cf-252 & $0.04 \%$ \\
Eu-152 & $0.04 \%$ \\
Eu-154 & $0.03 \%$ \\
I-131 & $0.03 \%$ \\
Ni-63 & $0.03 \%$ \\
U-234 & $0.02 \%$ \\
U-233 & $0.01 \%$ \\
\hline Total & $99.93 \%$ \\
\hline
\end{tabular}

a. Unless otherwise indicated, radionuclides are assumed to be in a particulate form.

\section{DESIGN OF AN AIR MONITORING NETWORK}

In the following subsections, determination of receptor/exposure scenarios, performance objectives, and relevant release quantities that can be used to design a hypothetical network or evaluate an existing network are presented.

\subsection{Idaho National Laboratory Receptor/Exposure Scenarios}

A survey conducted in 2013 by ESER (DOE-ID 2014c) identified 98 potential residences within approximately 5 miles of the INL Site boundary. The residences are qualified as potential because not all locations have a real full-time resident, but they have showed evidence of past habitation. Many of the potential residences were close to one another and could be represented by a single point. For this assessment, the 98 potential residences were reduced to 27 locations where receptor dose would be evaluated. Figure 3 shows the locations of the 27 potential residential receptors (i.e., yellow circles) and the locations of the 98 potential residences identified by ESER (i.e., black dots). Coordinates of the 27 potential residential receptors are presented in Table 5. The exposure scenario for potential residents will be referred to as the resident scenario. 


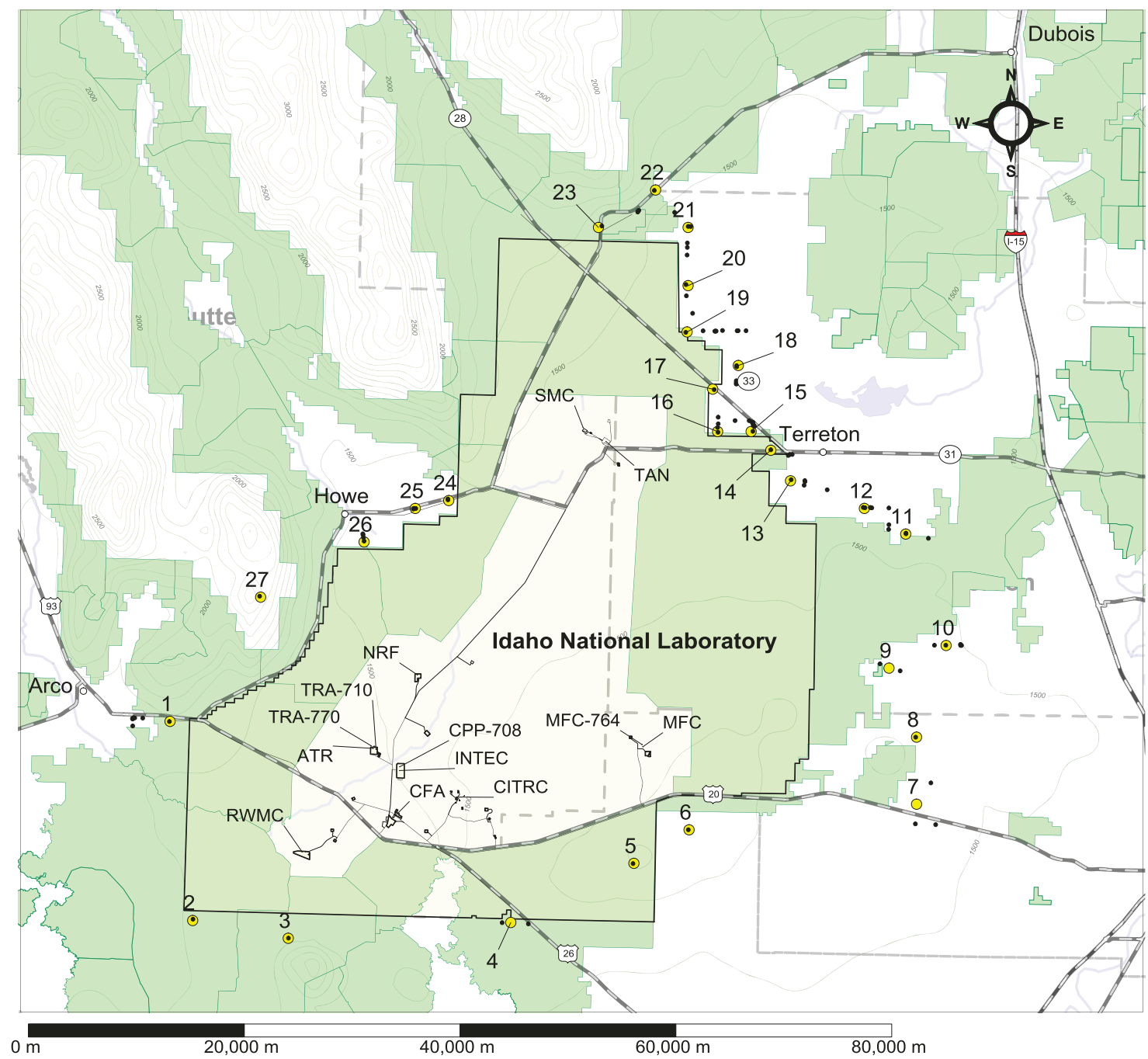

Figure 3. The 98 resident receptor locations identified by ESER (i.e., black dots) and the 27 resident receptor locations used in the model (yellow circles that are numbered 1 through 27). The figure also shows the grazing allotment boundaries (i.e., green-shaded regions) that extend off INL Site property.

Table 5. UTM coordinates of the 27 potential resident receptor locations used in the model. These receptors are treated as full-time residents.

\begin{tabular}{ccc}
\hline Receptor ID & UTM Easting $(\mathrm{m})$ & UTM Northing $(\mathrm{m})$ \\
\hline 1 & 322575 & 4830358 \\
2 & 324674 & 4811920 \\
3 & 333528 & 4810277 \\
4 & 354156 & 4811738 \\
5 & 365566 & 4817214 \\
6 & 370677 & 4820318 \\
7 & 391762 & 4822691 \\
8 & 391762 & 4828898 \\
9 & 389206 & 4835287 \\
\hline
\end{tabular}




\begin{tabular}{ccc}
\hline Receptor ID & UTM Easting $(\mathrm{m})$ & UTM Northing $(\mathrm{m})$ \\
\hline 10 & 394500 & 4837386 \\
11 & 390758 & 4847700 \\
12 & 386924 & 4850074 \\
13 & 380078 & 4852629 \\
14 & 378253 & 4855459 \\
15 & 376427 & 4857193 \\
16 & 373324 & 4857193 \\
17 & 372868 & 4861118 \\
18 & 375241 & 4863309 \\
19 & 370494 & 4866412 \\
20 & 370586 & 4870702 \\
21 & 370586 & 4876087 \\
22 & 367574 & 4879556 \\
23 & 362280 & 4876087 \\
24 & 348406 & 4850804 \\
25 & 345302 & 4850074 \\
26 & 340556 & 4846970 \\
27 & 330972 & 4841859 \\
\hline
\end{tabular}

a. UTM coordinate system, North American Datum 1983.

Also shown in Figure 3 are the grazing allotments on the INL Site where livestock are allowed to graze during summer months. Persons who tend the livestock (i.e., a shepherd or rancher) are not permanent residents because they do not reside on INL property, but are still members of the public; therefore, dose constraints to the public apply. For evaluation of the air monitoring network, the dose was evaluated for a person along the grazing allotment boundary nearest an INL Site source (Table 6). The exposure scenario for these receptors is referred to as the shepherd/rancher scenario.

The 27 potential residential receptor locations surrounding the INL Site are treated as full-time residents in the model. Doses were calculated for all potential exposure pathways using the parameters for the representative individual as described in Appendix B of the INL Annual Site Environmental Report (ASER) (DOE-ID 2014c). A simple means for implementing the all-pathway doses was to derive an all-pathway dose coefficient (APDC). The APDC is calculated using a unit dose factor from the ASER and an annual breathing rate $\left(\mathrm{m}^{3} /\right.$ year$)$ :

$$
A P D C=\frac{U D F}{B R}
$$

where

$U D F=$ unit dose factor derived from the ASER report (mrem/year per $\left.\mathrm{pCi} / \mathrm{m}^{3}\right)$

$B R=$ annual breathing rate for the reference individual $\left(8,033 \mathrm{~m}^{3}\right.$ year $\left.^{-1}\right)$.

Unit dose factors and APDCs were derived using information from the 2013 ASER report (DOE-ID 2014c) for releases from ATR. Because doses are normalized to the air concentration, the APDCs are independent of source location, source strength, and dispersion conditions; therefore, they only reflect the parameters of the dose calculation. 
Table 6. Distance from each INL facility to the nearest grazing allotment boundary for the shepherd/rancher scenario. These receptors are treated as transitory receptors.

\begin{tabular}{lcc}
\hline \multicolumn{1}{c}{ Facility } & Distance $(\mathrm{m})$ & Approximate Direction \\
\hline MFC-774 and MFC-764 & 3,800 & NNE \\
RWMC & 1,500 & SW \\
ATR and TRA-770 & 5,100 & NW \\
CPP-1777 and CPP-708 & 6,400 & SSW \\
NRF & 3,500 & NE \\
CFA-625 & 2,000 & SW \\
CITRC & 4,800 & SSW \\
TAN-625 & 3,400 & N \\
\hline
\end{tabular}

For the shepherd/rancher scenario, inhalation was the only exposure pathway considered because these persons are not residents but transient members of the public. The most conservative inhalation dose coefficients for a reference individual as provided in DOE-STD-1196-2011 (DOE 2011b) were used in the calculation. The breathing rate used in all dose calculations $\left(8,033 \mathrm{~m}^{3}\right.$ year $\left.^{-1}\right)$ is the breathing rate used for the reference individual's dose calculation in the ASER report (DOE-ID 2014c). APDCs and inhalation dose coefficient from DOE-STD-1196-2011 (DOE 2011b) are presented in Table 7.

Table 7. Unit dose factors, APDCs, and inhalation dose coefficients for the important radionuclides at the INL Site. All dose coefficients are for effective dose.

\begin{tabular}{lccc}
\hline \multicolumn{1}{c}{ Radionuclide $^{\mathrm{a}}$} & $\begin{array}{c}\text { Unit Dose Factor }^{\mathrm{b}} \\
\left(\mathrm{mrem} / \text { year per pCi } / \mathrm{m}^{3}\right)\end{array}$ & APDC $^{\mathrm{c}}\left(\mathrm{mrem} \mathrm{pCi}^{-1}\right)$ & $\begin{array}{c}\text { Inhalation Dose }_{\text {Coefficient }^{\mathrm{d}}} \\
\left(\mathrm{mrem} \mathrm{pCi}^{-1}\right)\end{array}$ \\
\hline $\mathrm{Am}-241$ & $3.01 \mathrm{E}+03$ & $3.74 \mathrm{E}-01$ & $3.63 \mathrm{E}-01$ \\
$\mathrm{Cs}-137$ & $3.44 \mathrm{E}+01$ & $4.29 \mathrm{E}-03$ & $8.21 \mathrm{E}-05$ \\
$\mathrm{H}-3$ (HTO $\left.^{\mathrm{e}}\right)$ & $7.14 \mathrm{E}-03$ & $8.89 \mathrm{E}-07$ & $7.14 \mathrm{E}-08$ \\
$\mathrm{I}-131$ (vapor) & $1.35 \mathrm{E}+01$ & $1.68 \mathrm{E}-03$ & $9.66 \mathrm{E}-05$ \\
$\mathrm{Pu}-238$ & $3.37 \mathrm{E}+03$ & $4.20 \mathrm{E}-01$ & $4.07 \mathrm{E}-01$ \\
$\mathrm{Pu}-239$ & $3.71 \mathrm{E}+03$ & $4.62 \mathrm{E}-01$ & $4.48 \mathrm{E}-01$ \\
Sr-90 & $9.00 \mathrm{E}+01$ & $1.12 \mathrm{E}-02$ & $6.07 \mathrm{E}-04$ \\
\hline
\end{tabular}

a. Unless otherwise indicated, radionuclides are in a particulate form.

b. Unit dose factors from 2013 ASER (DOE-ID 2014c).

c. APDC equation from Section 4.4.

d. DOE-STD-1196-2011 (DOE 2011b).

e. HTO is tritiated water vapor.

\subsection{Performance Objectives and Metrics}

In this analysis, performance objectives and metrics for the network are defined in terms of the network's ability to detect releases that would result in the dose constraint being met for a given receptor/exposure scenario. As stated in the DOE Handbook (2015), radionuclide concentrations that would cause an effective dose of $10 \%$ of the 10 -mrem/year effective dose standard (i.e., $1 \mathrm{mrem} /$ year) shall be readily detectable and distinguishable from background. To demonstrate compliance with this requirement, the residential and shepherd/rancher scenarios were established to correspond to persons at residences near the INL Site boundary (resident) and those grazing livestock on INL Site lands 
(shepherd/rancher), respectively. To address network performance in terms of meeting the aforementioned dose standards, the following performance objectives were established for the network:

1. A network FD of $95 \%$ or greater for a 1-week sampling time that results in a maximum dose of $0.0192 \mathrm{mrem}$ (or $1 \mathrm{mrem} /$ year if continuous over a year; $0.0192=1 / 52$ ) at a resident receptor location.

2. A network FD of $95 \%$ or greater for a 1-mrem dose from a 24 -hour release at the nearest distance to an INL grazing allotment.

Objective A is applicable to the resident scenario and doses are calculated using the all-pathway dose coefficients given in Table 7. Objective B is applicable to the shepherd/rancher scenario and uses the inhalation dose coefficients from DOE (2011b). Both exposure scenarios use an inhalation rate of $8,033 \mathrm{~m}^{3} /$ year and nominal values of sampler parameters that include a flow rate of $2 \mathrm{cfm}$ $\left(3.368 \mathrm{~m}^{3}\right.$ /hour), a sampling time of 168 hours (i.e., 1-week), and MDA values that are requested by ESER and routinely achieved by BEA for particulate and iodine sampling. For tritium releases, a flow rate of $0.019 \mathrm{~m}^{3} /$ hour, a sampling time of 648 hours (i.e., 27 days), and the ESER MDA were used (see Appendix B for details on tritium monitoring). Table 8 provides the radionuclide MDA, the TIC that corresponds to a dose of $0.0192 \mathrm{mrem}$ for the resident scenario and $1.0 \mathrm{mrem}$ for the shepherd/rancher scenario, and the corresponding amount of activity that would have accumulated on the filter. The amount of activity that accumulates on the filter is the product of TIC and the sampler flow rate. In all cases, the activity that would accumulate on the filter is significantly greater than the MDA. Thus, the sampling and analysis apparatus used by the INL Site is more than adequate to detect air concentrations that could result in the dose constraint being met. If the network fails to detect a release, then it is a result of sampler placement and not sampler performance.

Table 8. Radionuclide MDA values, TIC values that yield dose limits, and activity accumulated on filters for the given TIC value.

\begin{tabular}{|c|c|c|c|c|c|}
\hline \multirow[b]{2}{*}{ Radionuclide } & \multirow[b]{2}{*}{$\begin{array}{l}\text { MDA } \\
(\mathrm{pCi})\end{array}$} & \multicolumn{2}{|c|}{ Resident Scenario } & \multicolumn{2}{|c|}{ Shepherd/Rancher Scenario } \\
\hline & & $\begin{array}{l}\text { TIC for 0.0192-mrem } \\
\text { Dose }\left(\mathrm{pCi}^{-} \mathrm{hr} \mathrm{m}^{-3}\right)^{\mathrm{a}}\end{array}$ & $\begin{array}{c}\text { Activity } \\
\text { Accumulated on } \\
\text { Filter for Given } \\
\text { TIC (pCi) } \\
\end{array}$ & $\begin{array}{c}\text { TIC for } \\
\text { 1.0-mrem Dose } \\
\left(\mathrm{pCi}-\mathrm{hr} \mathrm{m}^{-1}\right)^{\mathrm{b}}\end{array}$ & $\begin{array}{c}\text { Activity } \\
\text { Accumulated on } \\
\text { Filter for Given } \\
\text { TIC (pCi) }\end{array}$ \\
\hline Am-241 & 0.029 & $5.60 \mathrm{E}-02$ & 0.188 & $3.01 \mathrm{E}+00$ & 10.1 \\
\hline Cs-137 & 0.700 & $4.88 \mathrm{E}+00$ & 16.4 & $1.33 \mathrm{E}+04$ & 44,727 \\
\hline $\mathrm{H}-3^{\mathrm{c}}$ & 0.752 & $2.36 \mathrm{E}+04$ & 448 & $1.53 \mathrm{E}+07$ & 290,130 \\
\hline $\mathrm{I}-131$ & 0.189 & $1.25 \mathrm{E}+01$ & 42.0 & $1.13 \mathrm{E}+04$ & 38,025 \\
\hline $\mathrm{Pu}-238$ & 0.022 & 4.99E-02 & 0.168 & $2.68 \mathrm{E}+00$ & 9.03 \\
\hline $\mathrm{Pu}-239$ & 0.022 & $4.53 \mathrm{E}-02$ & 0.153 & $2.43 \mathrm{E}+00$ & 8.19 \\
\hline Sr-90 & 0.215 & $1.87 \mathrm{E}+00$ & 6.29 & $1.80 \mathrm{E}+03$ & 6,049 \\
\hline
\end{tabular}

a. The dose that corresponds to this TIC is calculated using APDCs.

b. The dose that corresponds to this TIC is calculated using inhalation dose coefficients only.

c. In the case of tritium, the activity is accumulated in atmospheric moisture and based on a flow rate of $19 \mathrm{~L} / \mathrm{hour}$.

\subsection{Relevant Release Quantities}

The relevant radionuclide release quantity is the activity released from an INL Site facility that will not result in a stated effective dose constraint being exceeded for the applicable receptor scenario. Thus, the relevant release quantity is different for each INL Site emission source, each radionuclide, and each receptor scenario. The relevant release quantity for the resident scenario is the minimum activity of a radionuclide released from an INL facility that will result in a dose of 0.0192 mrem during a 1-week period at a resident location. The relevant release quantity for the shepherd/rancher scenario is the 
minimum activity of a radionuclide released from an INL facility that will result in dose of 1 mrem during a 24-hour period at a grazing allotment boundary.

For the resident scenario, relevant release quantities were calculated using the CALPUFF model described in Rood and Sondrup (2014), the resident receptors illustrated in Figure 3, and the all-pathway dose coefficients from Table 9. A similar procedure was applied to the shepherd/rancher scenario. However, a Gaussian plume model (see Appendix A) was used to calculate time-integrated concentrations for the shepherd/rancher scenario instead of the CALPUFF model. For evaluation of the shepherd/rancher scenario, 16 receptors spaced 22.5 degrees apart were situated around each INL source. The radial distance was the minimum distance from the source to the nearest grazing boundary (see Table 6). Because the person is not a resident, but is transitory, release quantities were based on inhalation only (Table 10). If a significant release did occur at the INL Site such that a 1-mrem dose would be incurred, then the person grazing livestock on INL Site property could be evacuated prior to their dose limit being exceeded. The procedure for determining the relevant release quantity for a shepherd/rancher is conservative for several reasons. First, the azimuth is not restricted to an azimuth that is on a grazing allotment boundary. Second, an entire year of meteorological data is considered even though grazing only occurs on the site during the late spring, summer, and early fall months.

Table 9. Release quantities (pCi) that would result in a maximum weekly dose of $0.0192 \mathrm{mrem}$ (equivalent to $1 \mathrm{mrem} /$ year if continuous over a year) at a residence location.

\begin{tabular}{lccccccc}
\hline \multicolumn{1}{c}{ Facility } & Am-241 & Cs-137 & H-3 & I-131 & Pu-238 & Pu-239 & Sr-90 \\
\hline ATR & $1.17 \mathrm{E}+09$ & $1.02 \mathrm{E}+11$ & & $2.62 \mathrm{E}+11$ & $1.05 \mathrm{E}+09$ & $9.51 \mathrm{E}+08$ & $3.92 \mathrm{E}+10$ \\
CFA-625 & $6.39 \mathrm{E}+08$ & $5.57 \mathrm{E}+10$ & & $1.42 \mathrm{E}+11$ & $5.69 \mathrm{E}+08$ & $5.17 \mathrm{E}+08$ & $2.13 \mathrm{E}+10$ \\
CITRC & $7.05 \mathrm{E}+08$ & $6.15 \mathrm{E}+10$ & & $1.57 \mathrm{E}+11$ & $6.28 \mathrm{E}+08$ & $5.71 \mathrm{E}+08$ & $2.36 \mathrm{E}+10$ \\
CPP-1774 & $1.02 \mathrm{E}+09$ & $8.93 \mathrm{E}+10$ & $4.31 \mathrm{E}+14$ & $2.28 \mathrm{E}+11$ & $9.12 \mathrm{E}+08$ & $8.29 \mathrm{E}+08$ & $3.42 \mathrm{E}+10$ \\
CPP-708 & $9.58 \mathrm{E}+08$ & $8.36 \mathrm{E}+10$ & & $2.13 \mathrm{E}+11$ & $8.53 \mathrm{E}+08$ & $7.76 \mathrm{E}+08$ & $3.20 \mathrm{E}+10$ \\
MFC-764 & $3.23 \mathrm{E}+09$ & $2.81 \mathrm{E}+11$ & & $7.19 \mathrm{E}+11$ & $2.88 \mathrm{E}+09$ & $2.61 \mathrm{E}+09$ & $1.08 \mathrm{E}+11$ \\
MFC-774 & $3.18 \mathrm{E}+08$ & $2.77 \mathrm{E}+10$ & & $7.07 \mathrm{E}+10$ & $2.83 \mathrm{E}+08$ & $2.57 \mathrm{E}+08$ & $1.06 \mathrm{E}+10$ \\
NRF & $1.68 \mathrm{E}+09$ & $1.47 \mathrm{E}+11$ & & $3.74 \mathrm{E}+11$ & $1.50 \mathrm{E}+09$ & $1.36 \mathrm{E}+09$ & $5.61 \mathrm{E}+10$ \\
RWMC & $4.29 \mathrm{E}+08$ & $3.74 \mathrm{E}+10$ & $1.81 \mathrm{E}+14$ & $9.56 \mathrm{E}+10$ & $3.82 \mathrm{E}+08$ & $3.48 \mathrm{E}+08$ & $1.43 \mathrm{E}+10$ \\
TAN-679 & $5.99 \mathrm{E}+08$ & $5.22 \mathrm{E}+10$ & & $1.33 \mathrm{E}+11$ & $5.33 \mathrm{E}+08$ & $4.85 \mathrm{E}+08$ & $2.00 \mathrm{E}+10$ \\
TRA-770 & $7.96 \mathrm{E}+08$ & $6.94 \mathrm{E}+10$ & $3.35 \mathrm{E}+14$ & $1.77 \mathrm{E}+11$ & $7.09 \mathrm{E}+08$ & $6.45 \mathrm{E}+08$ & $2.66 \mathrm{E}+10$ \\
\hline
\end{tabular}

Table 10. Release quantities (pCi) that would result in a maximum 24-hour dose of 1.0 mrem at the nearest distance to a grazing allotment from an INL Site facility.

\begin{tabular}{lccccccc}
\hline \multicolumn{1}{c}{ Facility } & Am-241 & Cs-137 & H-3 & I-131 & Pu-238 & Pu-239 & Sr-90 \\
\hline ATR & $3.99 \mathrm{E}+09$ & $9.410 \mathrm{E}+12$ & & $1.50 \mathrm{E}+13$ & $3.56 \mathrm{E}+09$ & $3.23 \mathrm{E}+09$ & $2.39 \mathrm{E}+12$ \\
CFA-625 & $1.43 \mathrm{E}+09$ & $3.378 \mathrm{E}+12$ & & $5.39 \mathrm{E}+12$ & $1.28 \mathrm{E}+09$ & $1.16 \mathrm{E}+09$ & $8.57 \mathrm{E}+11$ \\
CITRC & $3.74 \mathrm{E}+09$ & $8.802 \mathrm{E}+12$ & & $1.40 \mathrm{E}+13$ & $3.33 \mathrm{E}+09$ & $3.03 \mathrm{E}+09$ & $2.23 \mathrm{E}+12$ \\
CPP-1774 & $5.17 \mathrm{E}+09$ & $1.218 \mathrm{E}+13$ & $2.63 \mathrm{E}+16$ & $1.94 \mathrm{E}+13$ & $4.61 \mathrm{E}+09$ & $4.19 \mathrm{E}+09$ & $3.09 \mathrm{E}+12$ \\
CPP-708 & $1.18 \mathrm{E}+10$ & $2.784 \mathrm{E}+13$ & & $4.44 \mathrm{E}+13$ & $1.05 \mathrm{E}+10$ & $9.57 \mathrm{E}+09$ & $7.07 \mathrm{E}+12$ \\
MFC-764 & $4.08 \mathrm{E}+09$ & $9.628 \mathrm{E}+12$ & & $1.54 \mathrm{E}+13$ & $3.64 \mathrm{E}+09$ & $3.31 \mathrm{E}+09$ & $2.44 \mathrm{E}+12$ \\
MFC-774 & $2.44 \mathrm{E}+09$ & $5.742 \mathrm{E}+12$ & & $9.15 \mathrm{E}+12$ & $2.17 \mathrm{E}+09$ & $1.97 \mathrm{E}+09$ & $1.46 \mathrm{E}+12$ \\
\hline
\end{tabular}




\begin{tabular}{lccccccc}
\hline \multicolumn{1}{c}{ Facility } & Am-241 & Cs-137 & H-3 & I-131 & Pu-238 & Pu-239 & Sr-90 \\
\hline NRF & $3.63 \mathrm{E}+09$ & $8.551 \mathrm{E}+12$ & & $1.36 \mathrm{E}+13$ & $3.24 \mathrm{E}+09$ & $2.94 \mathrm{E}+09$ & $2.17 \mathrm{E}+12$ \\
RWMC & $8.88 \mathrm{E}+08$ & $2.094 \mathrm{E}+12$ & $4.52 \mathrm{E}+15$ & $3.34 \mathrm{E}+12$ & $7.92 \mathrm{E}+08$ & $7.20 \mathrm{E}+08$ & $5.31 \mathrm{E}+11$ \\
TAN-679 & $1.50 \mathrm{E}+09$ & $3.545 \mathrm{E}+12$ & & $5.65 \mathrm{E}+12$ & $1.34 \mathrm{E}+09$ & $1.22 \mathrm{E}+09$ & $9.00 \mathrm{E}+11$ \\
TRA-770 & $9.93 \mathrm{E}+09$ & $2.340 \mathrm{E}+13$ & $5.05 \mathrm{E}+16$ & $3.73 \mathrm{E}+13$ & $8.86 \mathrm{E}+09$ & $8.04 \mathrm{E}+09$ & $5.94 \mathrm{E}+12$ \\
\hline
\end{tabular}

The location of the highest dose for the resident receptor and shepherd/rancher scenarios are presented in Table 11 and Table 12, respectively. Note that the distance and azimuths listed in Table 12 for the shepherd/ rancher scenario do not necessarily correspond to a location within the grazing boundary. This procedure results in a conservative estimate of the minimum release quantity required to produce a 1-mrem dose, in addition to providing insight into the optimum locations for placing samplers.

Tritium for both receptor scenarios is treated differently because it involves sampling for water vapor instead of particulates. Moreover, tritium is only released in significant quantities from three facilities: ATR Complex, INTEC, and RWMC. For these reasons, tritium was only evaluated for these three facilities. Tritium release quantities and a description of the tritium samplers are provided in Appendix B.

Table 11. Location of reference resident for a 168-hour release (i.e., 1-week) that results in $0.0192 \mathrm{mrem}$ (1.0 mrem/year). See Figure 3 for a map of reference resident locations.

\begin{tabular}{cc}
\hline Facility & Reference Resident Location Number \\
\hline ATR & 3 \\
CFA-625 & 3 \\
CITRC & 4 \\
CPP-1774 & 3 \\
CPP-708 & 3 \\
MFC-764 & 5 \\
MFC-774 & 6 \\
NRF & 24 \\
RWMC & 3 \\
TAN-679 & 17 \\
TRA-770 & 3 \\
\hline
\end{tabular}

Table 12. Azimuth and distance from INL Site facilities that results in a maximum dose of 1-mrem for a 24-hour release (i.e., 1-day) for the shepherd/rancher scenario.

\begin{tabular}{ccc}
\hline Facility & Distance from Facility $(\mathrm{m})$ & Azimuth $^{\mathrm{b}, \mathrm{c}}($ degrees$)$ \\
\hline ATR & 1,500 & 67.5 \\
CFA-625 & 2,000 & 67.5 \\
CITRC & 4,800 & 67.5 \\
CPP-1774 & 6,400 & 67.5 \\
CPP-708 & 6,400 & 22.5 \\
MFC-764 & 3,800 & 270 \\
MFC-774 & 3,800 & 270 \\
NRF & 3,500 & 180 \\
RWMC & 1,500 & 90 \\
\hline
\end{tabular}




\begin{tabular}{ccc}
\hline Facility & Distance from Facility $^{\mathrm{a}}(\mathrm{m})$ & Azimuth $^{\mathrm{b}, \mathrm{c}}($ degrees $)$ \\
\hline TAN-679 & 3,400 & 180 \\
TRA-770 & 1,500 & 22.5 \\
\hline
\end{tabular}

a. Actual minimum distance from facility to nearest grazing allotment boundary.

b. Measured clockwise from north.

c. Direction does not necessarily correspond to direction of minimum distance to nearest grazing allotment.

\section{RESULTS}

FD and network intensity results are presented first for the hypothetical sampling network and then for the existing INL network. For the resident scenario, the hypothetical network assumes there is a sampler at each of the 27 resident locations near the INL boundary. For the shepherd/rancher scenario, 16 samplers are assumed to be placed 22.5 degrees apart and at a radial distance equal to the minimum distance from the INL Site emission source to the nearest grazing allotment boundary. Note that each INL Site emission source would have 16 samplers surrounding it.

\subsection{Frequency of Detection Results for Hypothetical Network}

FD and intensity results are presented in Table 13 for the resident scenario and Table 14 for the shepherd/rancher scenario. The resident scenario failed to achieve the performance objective of FD greater than or equal to $95 \%$. All actinides failed to meet the FD performance objective except $\mathrm{Pu}-238$ and $\mathrm{Pu}-239$ releases from NRF. However, fission and activation products and tritium met the performance objective for all INL Site emission sources. FD for actinides ranged from 38.6\% for Am-241 released from MFC 774 to $96.2 \%$ for $\mathrm{Pu}-238$ released from NRF.

Table 13. Network FD and intensity for a hypothetical sampling network consisting of samplers at each of the 27 resident locations for the resident scenario.

\begin{tabular}{|c|c|c|c|c|c|c|c|}
\hline \multirow[b]{2}{*}{ Facility } & \multicolumn{7}{|c|}{ Network FD } \\
\hline & Am-241 & Cs-137 & $\mathrm{Pu}-238$ & $\mathrm{Pu}-239$ & Sr-90 & $\mathrm{I}-131$ & $\mathrm{H}-3$ \\
\hline ATR & $87.93 \%$ & $100.00 \%$ & $91.69 \%$ & $89.55 \%$ & $100.00 \%$ & $100.00 \%$ & \\
\hline CFA-625 & $79.10 \%$ & $99.73 \%$ & $85.66 \%$ & $82.16 \%$ & $100.00 \%$ & $100.00 \%$ & \\
\hline CITRC & $72.51 \%$ & $100.00 \%$ & $79.70 \%$ & $75.47 \%$ & $100.00 \%$ & $100.00 \%$ & \\
\hline CPP-1774 & $85.22 \%$ & $100.00 \%$ & $90.42 \%$ & $87.60 \%$ & $100.00 \%$ & $100.00 \%$ & $100.00 \%$ \\
\hline CPP-708 & $56.76 \%$ & $90.82 \%$ & $64.31 \%$ & $58.90 \%$ & $95.82 \%$ & $100.00 \%$ & \\
\hline MFC-764 & $84.88 \%$ & $100.00 \%$ & $92.67 \%$ & $88.10 \%$ & $100.00 \%$ & $100.00 \%$ & \\
\hline MFC-774 & $38.63 \%$ & $98.56 \%$ & $49.33 \%$ & $42.65 \%$ & $100.00 \%$ & $100.00 \%$ & \\
\hline NRF & $93.54 \%$ & $100.00 \%$ & $96.23 \%$ & $95.04 \%$ & $100.00 \%$ & $100.00 \%$ & \\
\hline RWMC & $74.74 \%$ & $95.61 \%$ & $79.37 \%$ & $76.92 \%$ & $97.65 \%$ & $100.00 \%$ & $100.00 \%$ \\
\hline TAN-679 & $72.12 \%$ & $100.00 \%$ & $80.35 \%$ & $76.37 \%$ & $100.00 \%$ & $100.00 \%$ & \\
\hline \multirow[t]{2}{*}{ TRA-770 } & $48.67 \%$ & $90.37 \%$ & $55.52 \%$ & $51.23 \%$ & $94.25 \%$ & $100.00 \%$ & $100.00 \%$ \\
\hline & \multicolumn{7}{|c|}{ Network Intensity } \\
\hline Facility & Am-241 & Cs-137 & $\mathrm{Pu}-238$ & $\mathrm{Pu}-239$ & Sr-90 & $\mathrm{I}-131$ & $\mathrm{H}-3$ \\
\hline ATR & $8.27 \%$ & $37.67 \%$ & $10.18 \%$ & $9.02 \%$ & $44.19 \%$ & $91.69 \%$ & \\
\hline CFA-625 & $4.03 \%$ & $15.04 \%$ & $4.58 \%$ & $4.26 \%$ & $20.40 \%$ & $77.16 \%$ & \\
\hline CITRC & $3.32 \%$ & $21.62 \%$ & $4.17 \%$ & $3.60 \%$ & $28.34 \%$ & $81.84 \%$ & \\
\hline CPP-1774 & $5.77 \%$ & $34.42 \%$ & $7.39 \%$ & $6.39 \%$ & $41.07 \%$ & $89.95 \%$ & $99.76 \%$ \\
\hline CPP-708 & $2.24 \%$ & $9.40 \%$ & $2.66 \%$ & $2.34 \%$ & $13.30 \%$ & $70.55 \%$ & \\
\hline MFC-764 & $9.49 \%$ & $46.36 \%$ & $12.68 \%$ & $10.87 \%$ & $52.65 \%$ & $87.02 \%$ & \\
\hline
\end{tabular}




\begin{tabular}{|l|c|c|c|c|c|c|c|}
\hline MFC-774 & $2.07 \%$ & $14.38 \%$ & $2.92 \%$ & $2.38 \%$ & $18.01 \%$ & $55.70 \%$ & \\
\hline NRF & $19.24 \%$ & $55.40 \%$ & $22.94 \%$ & $20.84 \%$ & $62.55 \%$ & $95.76 \%$ & \\
\hline RWMC & $4.12 \%$ & $8.89 \%$ & $4.86 \%$ & $4.39 \%$ & $10.93 \%$ & $60.88 \%$ & $99.84 \%$ \\
\hline TAN-679 & $13.31 \%$ & $43.42 \%$ & $16.24 \%$ & $14.42 \%$ & $50.08 \%$ & $88.04 \%$ & \\
\hline TRA-770 & $1.85 \%$ & $7.96 \%$ & $2.22 \%$ & $1.98 \%$ & $11.04 \%$ & $67.57 \%$ & $99.66 \%$ \\
\hline
\end{tabular}

Table 14. Network FD and intensity for the 16 hypothetical samplers surrounding the facility at a distance equal to the nearest grazing allotment boundary for the shepherd/rancher scenario.

\begin{tabular}{|l|c|c|c|c|c|c|c|}
\hline & \multicolumn{7}{|c|}{ Network FD } \\
\hline \multicolumn{1}{|c|}{ Facility } & Am-241 & Cs-137 & Pu-238 & Pu-239 & Sr-90 & I-131 & H-3 \\
\hline ATR & $100 \%$ & $100 \%$ & $100 \%$ & $100 \%$ & $100 \%$ & $100 \%$ & \\
\hline CFA-625 & $100 \%$ & $100 \%$ & $100 \%$ & $100 \%$ & $100 \%$ & $100 \%$ & \\
\hline CITRC & $100 \%$ & $100 \%$ & $100 \%$ & $100 \%$ & $100 \%$ & $100 \%$ & \\
\hline CPP-1774 & $100 \%$ & $100 \%$ & $100 \%$ & $100 \%$ & $100 \%$ & $100 \%$ & $100 \%$ \\
\hline CPP-708 & $97.7 \%$ & $98.1 \%$ & $97.7 \%$ & $97.7 \%$ & $98.1 \%$ & $98.3 \%$ & \\
\hline MFC-764 & $97.0 \%$ & $98.0 \%$ & $97.1 \%$ & $97.0 \%$ & $98.0 \%$ & $98.0 \%$ & \\
\hline NRF & $100 \%$ & $100 \%$ & $100 \%$ & $100 \%$ & $100 \%$ & $100 \%$ & \\
\hline RWMC & $100 \%$ & $100 \%$ & $100 \%$ & $100 \%$ & $100 \%$ & $100 \%$ & \\
\hline TAN-679 & $100 \%$ & $100 \%$ & $100 \%$ & $100 \%$ & $100 \%$ & $100 \%$ & $100 \%$ \\
\hline TRA-770 & $97.4 \%$ & $98.2 \%$ & $97.7 \%$ & $97.4 \%$ & $98.1 \%$ & $98.5 \%$ & $98.5 \%$ \\
\hline & & $100 \%$ & $100 \%$ & $100 \%$ & $100 \%$ & $100 \%$ & \\
\hline Facility & Am-241 & Cs- 137 & Pu-238 & Pu- $\%$ & Sr-90 & I-131 & H-3 \\
\hline ATR & $51.1 \%$ & $62.1 \%$ & $52.0 \%$ & $51.4 \%$ & $61.4 \%$ & $63.2 \%$ & \\
\hline CFA-625 & $56.2 \%$ & $65.7 \%$ & $56.9 \%$ & $56.4 \%$ & $64.9 \%$ & $66.4 \%$ & \\
\hline CITRC & $51.5 \%$ & $62.4 \%$ & $52.4 \%$ & $51.9 \%$ & $61.7 \%$ & $63.5 \%$ & \\
\hline CPP-1774 & $49.9 \%$ & $61.2 \%$ & $50.6 \%$ & $50.1 \%$ & $60.3 \%$ & $62.1 \%$ & $62.7 \%$ \\
\hline CPP-708 & $39.3 \%$ & $47.7 \%$ & $40.0 \%$ & $39.5 \%$ & $47.1 \%$ & $48.5 \%$ & \\
\hline MFC-764 & $38.1 \%$ & $47.1 \%$ & $38.7 \%$ & $38.4 \%$ & $46.3 \%$ & $47.8 \%$ & \\
\hline MFC-774 & $50.7 \%$ & $62.1 \%$ & $51.4 \%$ & $51.1 \%$ & $61.3 \%$ & $63.1 \%$ & \\
\hline NRF & $54.9 \%$ & $65.7 \%$ & $55.7 \%$ & $55.3 \%$ & $64.6 \%$ & $66.9 \%$ & \\
\hline RWMC & $54.8 \%$ & $64.0 \%$ & $55.4 \%$ & $55.0 \%$ & $63.5 \%$ & $64.6 \%$ & $64.9 \%$ \\
\hline TAN-679 & $54.1 \%$ & $68.7 \%$ & $55.4 \%$ & $54.7 \%$ & $67.7 \%$ & $69.9 \%$ & \\
\hline TRA-770 & $40.2 \%$ & $48.0 \%$ & $40.6 \%$ & $40.4 \%$ & $47.4 \%$ & $48.9 \%$ & $49.3 \%$ \\
\hline
\end{tabular}

For the shepherd/rancher scenario, the performance objectives were met for all radionuclides and sources. This is not surprising because the hypothetical network had samplers placed in every principal azimuth location, thereby making it unlikely any release would go undetected. Individual sampler FD plots for Am-241 released from the TRA-770 stack, RWMC, MFC-764 stack, and TAN-679 facility are shown in Figure 4. The TRA-770 plot is characteristic of releases at INTEC, CFA, and CITRC. These plots illustrate that the FD varies with azimuth angle away from the facility and the magnitude is higher for ground-level releases compared to stack releases. In general, FD values were highest for samplers placed northeast and south-southwest of the facility. This is not surprising given these are the principal 
wind directions. Network performance that meets the performance criteria of FD greater than or equal to $95 \%$ could be achieved by a few samplers placed at strategic locations that are likely to capture releases.
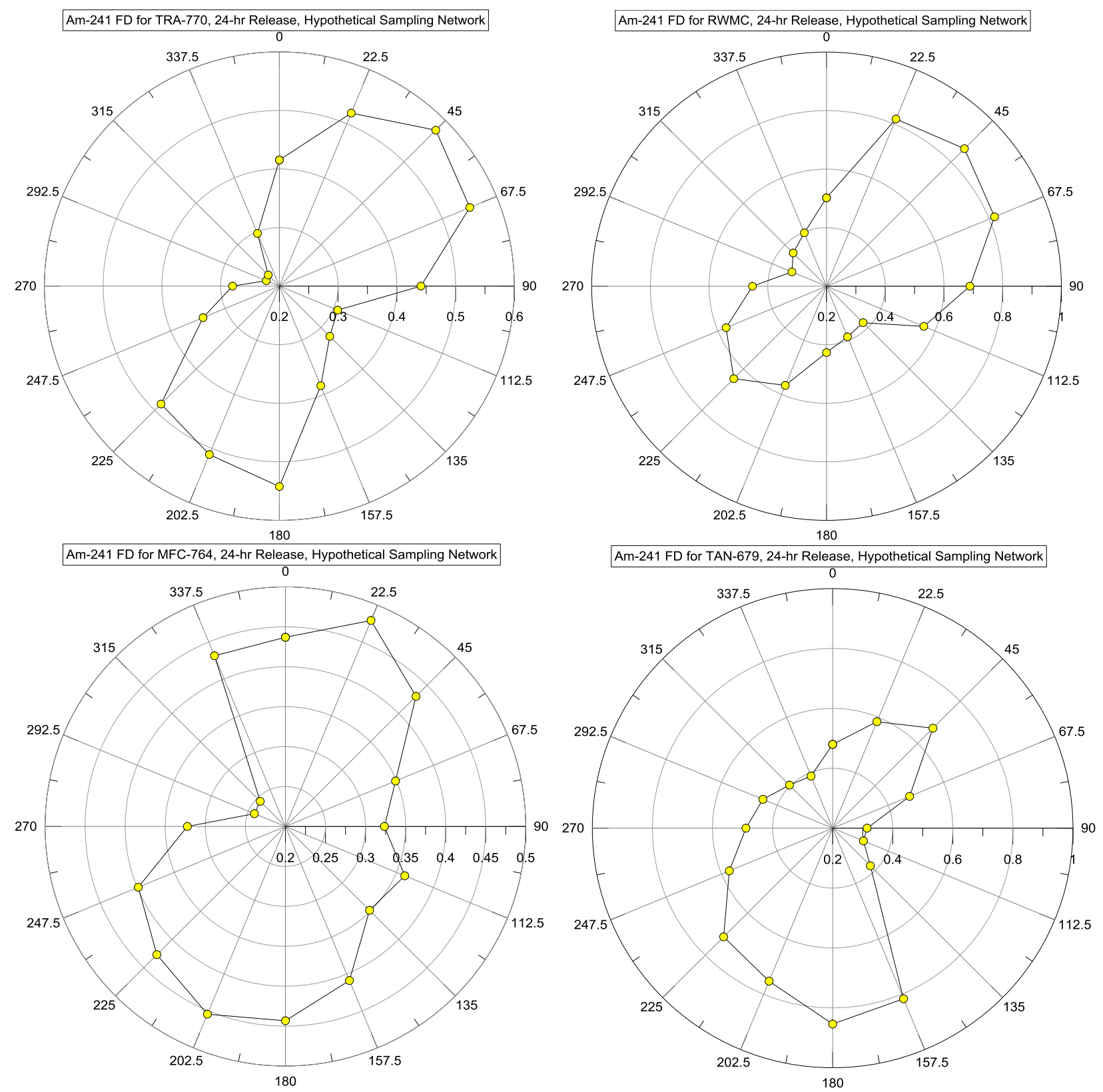

Figure 4. FD for a hypothetical network consisting of 16 samplers encircling the facility for the shepherd/rancher scenario. Plots are for 24-hour Am-241 releases from the TRA-770 stack, RWMC ground level, MFC-764 stack, and TAN-679 ground level.

\subsection{Frequency of Detection Results for the Existing Network}

Using the same release quantities for the resident scenario, the existing sampler network was evaluated (Table 15). For the resident scenario, the existing sampler network achieves the performance objectives for all radionuclides and facilities, meaning the current sampling network has a FD of greater than $95 \%$ for a fixed quantity of a radionuclide released over 168 hours from an INL Site facility. Again, the release quantity is such that the dose to a person at a resident location near the INL Site boundary 
from the activity released over 168 hours will be no greater than 0.0192 mrem. Network intensities generally ranged from 30 to $80 \%$, depending on the radionuclide, except for sources at MFC, where intensities were overall considerably lower. These results indicate that the current monitoring network can achieve the performance objectives for the resident scenario. However, overall performance of the sampling network can be improved by more efficient sampler placement, which is discussed in Section 7.3.

Table 15. Network FD and intensity for the existing INL Site sampling network consisting of 36 samplers for the resident scenario.

\begin{tabular}{|c|c|c|c|c|c|c|c|}
\hline \multirow[b]{2}{*}{ Facility } & \multicolumn{7}{|c|}{ Network FD } \\
\hline & Am-241 & Cs-137 & $\mathrm{Pu}-238$ & Pu-239 & Sr-90 & $\mathrm{I}-131$ & $\mathrm{H}-3$ \\
\hline ATR & $100 \%$ & $100 \%$ & $100 \%$ & $100 \%$ & $100 \%$ & $100 \%$ & \\
\hline CFA-625 & $100 \%$ & $100 \%$ & $100 \%$ & $100 \%$ & $100 \%$ & $100 \%$ & \\
\hline CITRC & $100 \%$ & $100 \%$ & $100 \%$ & $100 \%$ & $100 \%$ & $100 \%$ & \\
\hline CPP-1774 & $100 \%$ & $100 \%$ & $100 \%$ & $100 \%$ & $100 \%$ & $100 \%$ & $100 \%$ \\
\hline CPP-708 & $100 \%$ & $100 \%$ & $100 \%$ & $100 \%$ & $100 \%$ & $100 \%$ & \\
\hline MFC-764 & $100 \%$ & $100 \%$ & $100 \%$ & $100 \%$ & $100 \%$ & $100 \%$ & \\
\hline MFC-774 & $100 \%$ & $100 \%$ & $100 \%$ & $100 \%$ & $100 \%$ & $100 \%$ & \\
\hline $\mathrm{NRF}$ & $100 \%$ & $100 \%$ & $100 \%$ & $100 \%$ & $100 \%$ & $100 \%$ & \\
\hline RWMC & $100 \%$ & $100 \%$ & $100 \%$ & $100 \%$ & $100 \%$ & $100 \%$ & $100 \%$ \\
\hline TAN-679 & $100 \%$ & $100 \%$ & $100 \%$ & $100 \%$ & $100 \%$ & $100 \%$ & \\
\hline \multirow[t]{2}{*}{ TRA-770 } & $97.5 \%$ & $100 \%$ & $99.3 \%$ & $98.3 \%$ & $100 \%$ & $100 \%$ & $100 \%$ \\
\hline & \multicolumn{7}{|c|}{ Network Intensity } \\
\hline Facility & Am-241 & Cs-137 & $\mathrm{Pu}-238$ & Pu-239 & Sr-90 & $\mathrm{I}-131$ & H-3 \\
\hline ATR & $44.65 \%$ & $56.04 \%$ & $46.06 \%$ & $45.28 \%$ & $58.34 \%$ & $80.89 \%$ & \\
\hline CFA-625 & $37.98 \%$ & $49.48 \%$ & $40.01 \%$ & $38.77 \%$ & $51.36 \%$ & $70.15 \%$ & \\
\hline CITRC & $28.01 \%$ & $49.60 \%$ & $31.03 \%$ & $29.21 \%$ & $52.11 \%$ & $71.82 \%$ & \\
\hline СРP-1774 & $44.64 \%$ & $55.54 \%$ & $45.98 \%$ & $45.19 \%$ & $57.59 \%$ & $78.71 \%$ & $85.50 \%$ \\
\hline СРР-708 & $11.26 \%$ & $31.70 \%$ & $13.38 \%$ & $12.13 \%$ & $35.43 \%$ & $70.59 \%$ & \\
\hline MFC-764 & $5.05 \%$ & $33.42 \%$ & $6.51 \%$ & $5.56 \%$ & $40.87 \%$ & $82.39 \%$ & \\
\hline MFC-774 & $3.75 \%$ & $10.54 \%$ & $4.22 \%$ & $3.92 \%$ & $12.22 \%$ & $45.88 \%$ & \\
\hline $\mathrm{NRF}$ & $49.13 \%$ & $60.50 \%$ & $50.76 \%$ & $49.81 \%$ & $62.67 \%$ & $85.38 \%$ & \\
\hline RWMC & $32.12 \%$ & $45.03 \%$ & $34.63 \%$ & $33.26 \%$ & $46.57 \%$ & $64.25 \%$ & $69.05 \%$ \\
\hline TAN-679 & $8.22 \%$ & $41.11 \%$ & $10.48 \%$ & $9.14 \%$ & $46.74 \%$ & $72.13 \%$ & \\
\hline TRA-770 & $6.19 \%$ & $24.96 \%$ & $7.30 \%$ & $6.67 \%$ & $29.21 \%$ & $66.65 \%$ & $79.24 \%$ \\
\hline
\end{tabular}

Existing network FD results for the shepherd-rancher scenario are presented in Table 16. The FD was greater than $95 \%$ for all radionuclides and sources, except the actinide releases from MFC-764 stack, where FD values ranged from 92 to $94 \%$. For most of the facilities, samplers are in the major northeast and south-southwest wind directions from each facility. This is not true for MFC and RWMC, where there are gaps in the sampler network based on wind direction. These two sources had the lowest FD values.

It is also noteworthy to mention that more activity was released in the shepherd/rancher scenario compared to the resident scenario, yet FD values for the shepherd/rancher scenario were less than the resident scenario. This apparent contradictory result is because in the shepherd/rancher scenario, the activity is released over 24-hours instead of 1-week for the resident scenario. Releasing the activity over a 
shorter time interval limits the number of samplers that may be impacted by the release. And in the case of MFC, very few samplers are in locations that are likely to be impacted by the release.

This analysis shows that performance objectives were achieved for all facilities except MFC. Rearrangement of existing samplers, as discussed in a later section, will address this deficiency in the current network.

Table 16. Network FD and intensity for the existing INL Site sampling network consisting of 36 samplers for the shepherd/rancher scenario.

\begin{tabular}{|c|c|c|c|c|c|c|c|}
\hline & \multicolumn{7}{|c|}{ Network FD } \\
\hline Facility & Am-241 & Cs-137 & $\mathrm{Pu}-238$ & Pu-239 & Sr-90 & $\mathrm{I}-131$ & $\mathrm{H}-3$ \\
\hline ATR & $100 \%$ & $100 \%$ & $100 \%$ & $100 \%$ & $100 \%$ & $100 \%$ & \\
\hline CFA-625 & $99 \%$ & $100 \%$ & $98.8 \%$ & $98.7 \%$ & $99.5 \%$ & $100 \%$ & \\
\hline CITRC & $100 \%$ & $100 \%$ & $100 \%$ & $100 \%$ & $100 \%$ & $100 \%$ & \\
\hline CPP-1774 & $100 \%$ & $100 \%$ & $100 \%$ & $100 \%$ & $100 \%$ & $100 \%$ & $100 \%$ \\
\hline СРP-708 & $100 \%$ & $100 \%$ & $100 \%$ & $100 \%$ & $100 \%$ & $100 \%$ & \\
\hline MFC-764 & $92 \%$ & $100 \%$ & $94.2 \%$ & $93.0 \%$ & $100 \%$ & $100 \%$ & \\
\hline MFC-774 & $99 \%$ & $100 \%$ & $99.4 \%$ & $99.3 \%$ & $100 \%$ & $100 \%$ & \\
\hline NRF & $100 \%$ & $100 \%$ & $100 \%$ & $100 \%$ & $100 \%$ & $100 \%$ & \\
\hline RWMC & $96.9 \%$ & $98.7 \%$ & $96.9 \%$ & $96.9 \%$ & $98.6 \%$ & $99.1 \%$ & $98.7 \%$ \\
\hline TAN-679 & $100 \%$ & $100 \%$ & $100 \%$ & $100 \%$ & $100 \%$ & $100 \%$ & \\
\hline \multirow[t]{2}{*}{ TRA-770 } & $100 \%$ & $100 \%$ & $100 \%$ & $100 \%$ & $100 \%$ & $100 \%$ & $97.8 \%$ \\
\hline & \multicolumn{7}{|c|}{ Network Intensity } \\
\hline Facility & Am-241 & Cs-137 & $\mathrm{Pu}-238$ & Pu-239 & Sr-90 & $\mathrm{I}-131$ & H-3 \\
\hline ATR & $44.4 \%$ & $79.9 \%$ & $45.7 \%$ & $44.9 \%$ & $77.5 \%$ & $82.3 \%$ & \\
\hline CFA-625 & $32.2 \%$ & $75.9 \%$ & $33.5 \%$ & $32.8 \%$ & $71.7 \%$ & $79.6 \%$ & \\
\hline CITRC & $37.7 \%$ & $76.8 \%$ & $39.4 \%$ & $38.4 \%$ & $74.0 \%$ & $79.2 \%$ & \\
\hline CPP-1774 & $46.6 \%$ & $80.3 \%$ & $48.0 \%$ & $47.2 \%$ & $77.9 \%$ & $82.6 \%$ & $78.4 \%$ \\
\hline СРP-708 & $38.7 \%$ & $74.3 \%$ & $40.8 \%$ & $39.5 \%$ & $72.0 \%$ & $76.4 \%$ & \\
\hline MFC-764 & $10.3 \%$ & $62.6 \%$ & $12.0 \%$ & $10.9 \%$ & $58.9 \%$ & $66.1 \%$ & \\
\hline MFC-774 & $16.9 \%$ & $69.2 \%$ & $18.7 \%$ & $17.6 \%$ & $65.3 \%$ & $72.7 \%$ & \\
\hline NRF & $42.5 \%$ & $78.3 \%$ & $43.8 \%$ & $43.0 \%$ & $75.8 \%$ & $80.8 \%$ & \\
\hline RWMC & $31.6 \%$ & $76.3 \%$ & $32.9 \%$ & $32.2 \%$ & $71.3 \%$ & $80.8 \%$ & $75.0 \%$ \\
\hline TAN-679 & $25.5 \%$ & $71.3 \%$ & $27.4 \%$ & $26.3 \%$ & $67.1 \%$ & $74.8 \%$ & \\
\hline TRA-770 & $35.2 \%$ & $74.7 \%$ & $37.5 \%$ & $36.2 \%$ & $72.3 \%$ & $76.9 \%$ & $73.2 \%$ \\
\hline
\end{tabular}

\subsection{Network Optimization}

The FD methodology was used to evaluate the existing INL Site monitoring network to determine if it meets the performance objective of greater than or equal to 95\% FD (see Section 6.2). The FD values for the resident scenario showed that the existing sampler network achieved the performance objectives for all radionuclides and facilities. The shepherd/rancher scenario met performance objectives for all radionuclides and facilities except actinides released from the MFC-764 stack. Inadequate sampler coverage around the facility was identified as the cause for not meeting the performance objective. Thus, addition or rearrangement of individual samplers to locations that are more effective in terms of detecting releases was considered as the first step of network optimization. The second step was to evaluate removal of samplers that have little effect on sampler network performance. 


\subsubsection{Sampling Locations}

Based on the FD analysis reported in Section 6, several recommendations are proposed concerning placement of samplers that will result in overall better system performance. The FD plots as a function of azimuth location that are shown in Figure 4 provide a general guide to where samplers should be placed relative to a facility to improve FD. In general, samplers should be placed northeast and south-southwest of the release points; although there is some leeway in actual sampler placement as illustrated in Figure 4. For example, consider the FD values for the TRA-770 stack. Samplers placed at 22.5 and 67.5 degrees have only a slightly less FD than the sampler placed at 45 degrees. The current sampling network has samplers placed in these directions for sources at ATR and INTEC. Samplers are also placed in the principal wind directions for TAN and NRF. However, the RWMC and MFC facilities are lacking samplers in the principal wind direction or, if a sampler is present, it is too far from the source to detect a release. Releases from RWMC that travel northeast from the facility will impact the dense sampler network at CFA, INTEC, and ATR. However, no samplers are present for plumes that travel southwest from RWMC. For MFC, a sampler is situated north-northeast of the facility at Terreton. However, this sampler is too distant and dilution and dispersion reduces air concentrations below the sampler detection limit. The sampler at Atomic City (ESER-ATO) is well placed and has the highest FD apart from the sampler at MFC. However, an additional sampler placed closer to the facility in a south-southwest direction would improve FD. Overall observations and recommendations are as follows:

- The BEA-ARA sampler is not a very effective location. For example, removing it from the network for a 24-hour release from CITRC would result in an inconsequential reduction of the FD (the FD for Am-241 is reduced to $99.44 \%$ from $99.58 \%$ ). It would be better to move it south-southwest of MFC, if possible, to improve detection of releases from MFC.

- Adding a sampler south-southwest and northeast of MFC would achieve the performance objective of 95\% FD for actinides. Placing a sampler at Location 5 (i.e., south-southwest of MFC) and

Location 11 (northeast of MFC) would result in FD values of over 95\% for all actinides for a 24-hour release.

- The sampler FAA-ESER could also be removed or moved to south-southwest of MFC. Removing the sampler from the network does not appreciably change the FD for an 8 or 24-hour release.

- Adding a sampler southwest of RWMC would improve overall detection frequencies. For a 24-hour release from RWMC it was shown that a 95\% FD could be achieved with only two samplers placed northeast and southwest of RWMC.

- Removing samplers BEA-PBF, BEA-ARA, ESER-FAI, and ESER-MAI would not result in FD values for the CPP-708 stack or releases from CITRC from dropping below 95\% for all radionuclides considered.

A contour plot of the annual average dispersion factor for the MFC-764 stack (Figure 5) shows that resident locations 11 and 5 lay within the principal path of the simulated plume from the stack; therefore, FD would improve if samplers are placed near these locations. Also note that the ESER-FAA and BEA-ARA samplers are outside the 0.0002 contours. A plot of the FD versus azimuth for all existing samplers and resident receptors (Figure 6) shows that adding samplers south-southwest and northeast of the MFC facility would enhance FD. The rather large FD at 100 degrees is from the onsite MFC sampler. Also note that samplers east and west of MFC add little or nothing to the overall FD.

To test the proposed changes in the network, sampler locations where power is accessible were identified at locations north and south of MFC and south of RWMC. The proposed southern sampler at MFC would be located at the guard shack on the main access road. These sampler locations were added to the existing network and samplers at BEA-PBF, BEA-ARA, ESER-FAA, and ESEF-MAI were removed because these samplers were shown to not change the overall FD for release from the CPP-708 stack. The results of the optimization runs are presented in Table 17 for the shepherd/rancher scenario. Tritium is not 
reported because no changes to the tritium monitoring network are proposed. The results demonstrate that with the proposed changed to the monitoring network, the performance objective of greater than or equal to $95 \%$ FD for the shepherd/rancher scenario is achieved. FREQD output files for the resident scenario using the optimized network are presented in Appendix C.

Table 18presents the percent change in FD and intensity from the optimized network to the existing network. Percent change was calculated using

$\% C=\frac{X_{o}-X_{e}}{X_{o}}$

where $X_{o}=$ the FD or intensity of the modified network and $X_{e}=$ the existing FD or intensity. A negative percent change indicates the performance measure (i.e., $F D$ or intensity) for the optimized network decreased from the existing network. A positive percent change indicates the performance measure for the optimized network increased from the existing network.

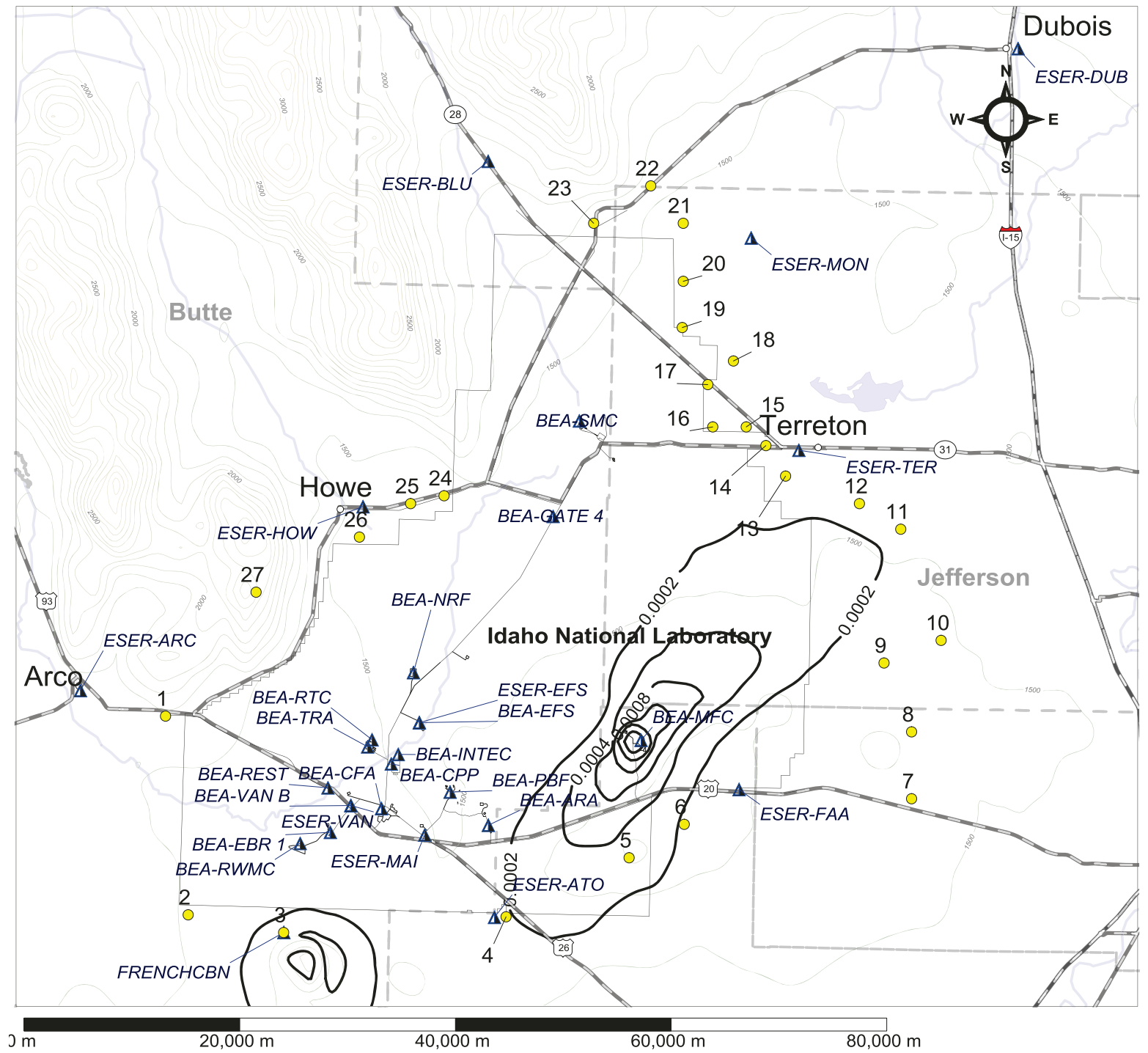

Figure 5. Contour plot of the annual average dispersion factor (or $\mathrm{X} / \mathrm{Q}$ in $\mathrm{s} / \mathrm{m}^{3}$ ) for a steady-state release from MFC-764 stack. 


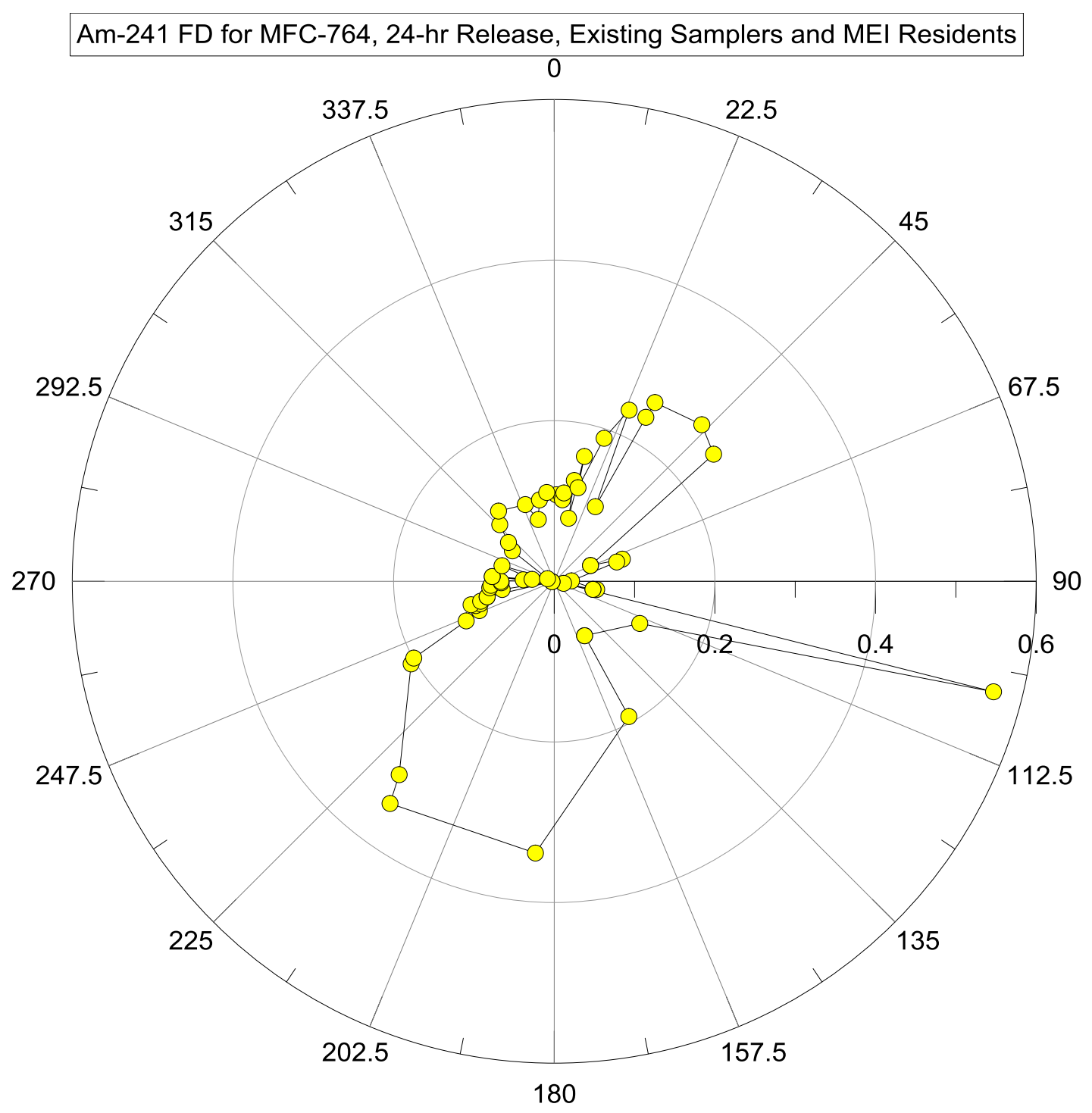

Figure 6. FD versus azimuth for Am-241 released from the MFC-764 stack over a 24-hour period. The rather large FD at azimuth 100 degrees is from the onsite MFC sampler.

Removing the four samplers previously mentioned results in a small decrease in FD (less than 1.5\%) for sources at CFA, CITRC, and TAN, and decreases in network intensity for sources at ATR, CITRC, CFA, RWMC, and TAN. However, all sources meet the performance objective of greater than or equal to $95 \%$ FD. Adding samplers at MFC and RWMC improved the FD by up to $6.95 \%$ for the MFC-764 stack source and $3.08 \%$ for the RWMC sources. If only the samplers at ESER-FAA and BEA-ARA are removed, there is no appreciable change in network FD and intensity.

Individual sampler FDs for a 24-hour release of Am-241 from the MFC-764 stack were $78.2 \%$ for the proposed MFC north sampler and $65.5 \%$ for the proposed sampler at the MFC guard shack. The existing MFC sampler had an FD of 59.4\%. Moving the existing MFC sampler to the MFC parking lot had no appreciable change on FD. Individual sampler FDs for 24-hour Am-241 releases from RWMC were $79.9 \%$ for the proposed RWMC south sampler and $96.8 \%$ for the existing RWMC sampler. 
Table 17. Network FD and intensity for the optimized INL Site sampling network and the shepherd/rancher scenario for a 24-hour release.

\begin{tabular}{|l|c|c|c|c|c|c|}
\hline & \multicolumn{7}{|c|}{ Optimized Network Frequency of Detection } \\
\hline Facility & Am-241 & Cs-137 & Pu-238 & Pu-239 & Sr-90 & I-131 \\
\hline ATR & $100.0 \%$ & $100.0 \%$ & $100.0 \%$ & $100.0 \%$ & $100.0 \%$ & $100.0 \%$ \\
\hline CFA-625 & $98.0 \%$ & $99.9 \%$ & $98.6 \%$ & $98.3 \%$ & $99.9 \%$ & $99.9 \%$ \\
\hline CITRC & $98.3 \%$ & $99.8 \%$ & $98.4 \%$ & $98.3 \%$ & $99.8 \%$ & $99.8 \%$ \\
\hline CPP-1774 & $100.0 \%$ & $100.0 \%$ & $100.0 \%$ & $100.0 \%$ & $100.0 \%$ & $100.0 \%$ \\
\hline CPP-708 & $100.0 \%$ & $100.0 \%$ & $100.0 \%$ & $100.0 \%$ & $100.0 \%$ & $100.0 \%$ \\
\hline MFC-764 & $98.7 \%$ & $100.0 \%$ & $99.0 \%$ & $98.9 \%$ & $100.0 \%$ & $100.0 \%$ \\
\hline MFC-774 & $100.0 \%$ & $100.0 \%$ & $100.0 \%$ & $100.0 \%$ & $100.0 \%$ & $100.0 \%$ \\
\hline NRF & $99.8 \%$ & $100.0 \%$ & $99.8 \%$ & $99.8 \%$ & $100.0 \%$ & $100.0 \%$ \\
\hline RWMC & $100.0 \%$ & $100.0 \%$ & $100.0 \%$ & $100.0 \%$ & $100.0 \%$ & $100.0 \%$ \\
\hline TAN-679 & $99.3 \%$ & $100.0 \%$ & $99.5 \%$ & $99.4 \%$ & $100.0 \%$ & $100.0 \%$ \\
\hline TRA-770 & $99.8 \%$ & $100.0 \%$ & $99.8 \%$ & $99.8 \%$ & $100.0 \%$ & $100.0 \%$ \\
\hline & & & Optimized Network Intensity & & \\
\hline Facility & Am-241 & Cs-137 & Pu-238 & Pu-239 & Sr-90 & I-131 \\
\hline ATR & $43.8 \%$ & $77.9 \%$ & $45.2 \%$ & $44.4 \%$ & $77.2 \%$ & $82.2 \%$ \\
\hline CFA-625 & $30.2 \%$ & $72.2 \%$ & $31.6 \%$ & $30.8 \%$ & $71.0 \%$ & $79.1 \%$ \\
\hline CITRC & $35.5 \%$ & $76.4 \%$ & $37.2 \%$ & $36.2 \%$ & $73.6 \%$ & $79.0 \%$ \\
\hline CPP-1774 & $45.7 \%$ & $78.3 \%$ & $47.1 \%$ & $46.3 \%$ & $77.7 \%$ & $82.4 \%$ \\
\hline CPP-708 & $39.3 \%$ & $74.4 \%$ & $41.3 \%$ & $40.1 \%$ & $72.0 \%$ & $76.4 \%$ \\
\hline MFC-764 & $13.4 \%$ & $63.0 \%$ & $14.9 \%$ & $14.0 \%$ & $59.2 \%$ & $66.5 \%$ \\
\hline MFC-774 & $17.4 \%$ & $66.7 \%$ & $19.1 \%$ & $18.1 \%$ & $65.6 \%$ & $73.1 \%$ \\
\hline NRF & $42.5 \%$ & $76.6 \%$ & $43.8 \%$ & $43.0 \%$ & $75.8 \%$ & $80.8 \%$ \\
\hline RWMC & $31.3 \%$ & $72.0 \%$ & $32.6 \%$ & $31.9 \%$ & $70.8 \%$ & $80.5 \%$ \\
\hline TAN-679 & $24.9 \%$ & $68.1 \%$ & $26.8 \%$ & $25.7 \%$ & $67.1 \%$ & $74.8 \%$ \\
\hline TRA-770 & $36.2 \%$ & $73.0 \%$ & $38.4 \%$ & $37.2 \%$ & $72.4 \%$ & $77.0 \%$ \\
\hline
\end{tabular}

Table 18. Percent change in network FD and intensity from the optimized and existing network.

\begin{tabular}{|l|c|c|c|c|c|c|}
\hline & \multicolumn{6}{|c|}{ Percent Change for Frequency of Detection } \\
\hline \multicolumn{1}{|c|}{ Facility } & Am-241 & Cs-137 & Pu-238 & Pu-239 & Sr-90 & I-131 \\
\hline ATR & $0.00 \%$ & $0.00 \%$ & $0.00 \%$ & $0.00 \%$ & $0.00 \%$ & $0.00 \%$ \\
\hline CFA-625 & $-0.66 \%$ & $0.39 \%$ & $-0.20 \%$ & $-0.36 \%$ & $0.39 \%$ & $0.36 \%$ \\
\hline CITRC & $-1.34 \%$ & $-0.16 \%$ & $-1.30 \%$ & $-1.30 \%$ & $-0.16 \%$ & $-0.16 \%$ \\
\hline CPP-1774 & $0.00 \%$ & $0.00 \%$ & $0.00 \%$ & $0.00 \%$ & $0.00 \%$ & $0.00 \%$ \\
\hline CPP-708 & $0.00 \%$ & $0.00 \%$ & $0.00 \%$ & $0.00 \%$ & $0.00 \%$ & $0.00 \%$ \\
\hline MFC-764 & $6.95 \%$ & $0.10 \%$ & $4.79 \%$ & $5.97 \%$ & $0.10 \%$ & $0.07 \%$ \\
\hline MFC-774 & $0.74 \%$ & $0.10 \%$ & $0.61 \%$ & $0.70 \%$ & $0.01 \%$ & $0.01 \%$ \\
\hline NRF & $0.00 \%$ & $0.00 \%$ & $0.00 \%$ & $0.00 \%$ & $0.00 \%$ & $0.00 \%$ \\
\hline RWMC & $3.08 \%$ & $1.40 \%$ & $3.08 \%$ & $3.08 \%$ & $1.37 \%$ & $0.93 \%$ \\
\hline TAN-679 & $-0.34 \%$ & $0.00 \%$ & $-0.37 \%$ & $-0.44 \%$ & $0.00 \%$ & $0.00 \%$ \\
\hline TRA-770 & $0.00 \%$ & $0.00 \%$ & $0.00 \%$ & $0.00 \%$ & $0.00 \%$ & $0.00 \%$ \\
\hline
\end{tabular}




\begin{tabular}{|l|c|c|c|c|c|c|}
\hline & \multicolumn{7}{|c|}{ Percent Change for Intensity } \\
\hline \multicolumn{1}{|c|}{ Facility } & Am-241 & Cs-137 & Pu-238 & Pu-239 & Sr-90 & I-131 \\
\hline ATR & $-1.23 \%$ & $-0.26 \%$ & $-1.22 \%$ & $-1.26 \%$ & $-0.30 \%$ & $-0.09 \%$ \\
\hline CFA-625 & $-6.52 \%$ & $-0.93 \%$ & $-6.11 \%$ & $-6.33 \%$ & $-1.03 \%$ & $-0.61 \%$ \\
\hline CITRC & $-6.32 \%$ & $2.30 \%$ & $-5.72 \%$ & $-6.03 \%$ & $-0.56 \%$ & $-0.34 \%$ \\
\hline CPP-1774 & $-2.03 \%$ & $-0.31 \%$ & $-1.91 \%$ & $-1.94 \%$ & $-0.33 \%$ & $-0.18 \%$ \\
\hline CPP-708 & $1.50 \%$ & $2.49 \%$ & $1.28 \%$ & $1.45 \%$ & $0.11 \%$ & $0.05 \%$ \\
\hline MFC-764 & $23.34 \%$ & $4.96 \%$ & $19.45 \%$ & $21.94 \%$ & $0.57 \%$ & $0.60 \%$ \\
\hline MFC-774 & $2.87 \%$ & $0.45 \%$ & $1.89 \%$ & $2.49 \%$ & $0.44 \%$ & $0.51 \%$ \\
\hline NRF & $0.00 \%$ & $0.00 \%$ & $0.00 \%$ & $0.00 \%$ & $0.00 \%$ & $0.00 \%$ \\
\hline RWMC & $-0.93 \%$ & $-0.65 \%$ & $-1.10 \%$ & $-1.00 \%$ & $-0.69 \%$ & $-0.37 \%$ \\
\hline TAN-679 & $-2.25 \%$ & $-0.07 \%$ & $-2.16 \%$ & $-2.29 \%$ & $-0.06 \%$ & $0.00 \%$ \\
\hline TRA-770 & $2.79 \%$ & $0.16 \%$ & $2.34 \%$ & $2.58 \%$ & $0.17 \%$ & $0.09 \%$ \\
\hline
\end{tabular}

\section{CONCLUSIONS}

The existing INL air monitoring network was shown to be more than adequate for detection of radionuclide releases capable of delivering a dose of $1 \mathrm{mrem}$ for all INL Site emission sources except those at MFC. Performance of individual samplers revealed that samplers at BEA-PBF, BEA-ARA, ESER-FAA, and ESEF-MAI were not effective in detecting releases from MFC emission sources. Although these air monitoring stations have good detection (FD approximately greater than or equal to $50 \%$ ) from other INL Site emission sources, removing these samplers from the network was shown to not seriously impact the network FD. Adding samplers northeast and southwest of MFC and a sampler southwest of RWMC substantially improved the FD for MFC and RWMC emission sources. Thus, a network that meets the performance objective of FD greater than or equal to $95 \%$ can be achieved by actually reducing the total number of samplers in the existing network. It is more important that samplers are placed at locations that are likely to detect releases, meaning the placement of samplers is as or more important than the total number of samplers. Although annual average dispersion patterns, which roughly follow the patterns of the wind rose, provide a good first cut of where to initially place samplers, FD methods provide a quantitative measure of the overall effectiveness of a sampler and the network as a whole.

\section{REFERENCES}

40 CFR 61, Subpart H, 2006, "National Emission Standards for Emissions of Radionuclides Other than Radon from Department of Energy Facilities," Code of Federal Regulations, Office of the Federal Register, July 2006.

DOE, 2011a, DOE Order 458.1, "Radiation Protection of the Public and Environment," February 2011.

DOE, 2011b, "U.S. Derived Concentration Technical Standard, Department of Energy Standard," DOE-STD-1196-2011, April 2011.

DOE-ID, 2014a, Technical Basis for Environmental Monitoring and Surveillance at the Idaho National Laboratory, DOE/ID-11485, U.S. Department of Energy, Idaho Operations Office.

DOE-ID, 2014b, National Emissions Standards for Hazardous Air Pollutants-Calendar Year 2013 INL Report for Radionuclides, DOE/ID-11441, U.S. Department of Energy, Idaho Operations Office. 
DOE-ID, 2014c, Idaho National Laboratory Site Environmental Report Calendar Year 2013, DOE/ID-12082 (13), U.S. Department of Energy, Idaho Operations Office, Environmental Surveillance, Education, and Research Program.

DOE, 2015, DOE Handbook-Environmental Radiological Effluent Monitoring and Environmental Surveillance, DOE-HDBK-1216-2015, U.S. Department of Energy.

EPA, 1972, Environmental Radioactivity Surveillance Guide, EPA Office of Radiation Programs, ORP/SID 72-2.

Rood, A.S., and A.J. Sondrup, 2014, Development and Demonstration of a Methodology to Quantitatively Assess the INL Site Ambient Air Monitoring Network, INL/EXT-14-33194, Idaho National Laboratory.

Scire, J. S., D. G. Strimaitis, and R. J. Yamartino, 2000a, A User's Guide for the CALPUFF Dispersion Model Version 5, Earth Tech Inc., Concord, Massachusetts.

Scire, J. S., F. R. Robe, M. E. Fernau, and R. J. Yamartino, 2000b, A User's Guide for the CALMET Meteorological Model Version 5, Earth Tech Inc., Concord, Massachusetts. 


\section{Appendix A \\ Gaussian Plume Model}

This appendix contains a description of the Gaussian plume model and its implementation in a Perl script for generation of TICs for use in FD analysis.

\section{A-1. GAUSSIAN PLUME FORMULATION}

The Gaussian plume model for a conservative tracer with no deposition or depletion is given by (Turner 1994):

$$
\begin{aligned}
& \chi(x, y, z, u, H, Q)=\frac{Q}{2 \pi u \sigma_{y} \sigma_{z}} \exp \left\lfloor-\frac{y^{2}}{2 \sigma_{y}^{2}}\right\rfloor G(z) \\
& G(z)=\sum_{n=-\infty}^{\infty}\left\{\exp \left[-\frac{1}{2}\left(\frac{2 n H-z_{h}-z}{\sigma_{z}}\right)^{2}\right]+\exp \left[-\frac{1}{2}\left(\frac{2 n H+z_{h}-z}{\sigma_{z}}\right)^{2}\right]\right\}
\end{aligned}
$$

where

$$
\begin{array}{ll}
x & =\text { downwind distance }(\mathrm{m}) \\
y & =\text { crosswind distance }(\mathrm{m}) \\
z & =\text { height above ground }(\mathrm{m}) \\
u & =\text { wind speed }\left(\mathrm{m} \mathrm{s}^{-1}\right) \\
z_{h} & =\text { plume height }(\text { stack height plus plume rise })(\mathrm{m}) \\
H & =\text { mixing height }(\mathrm{m}) \\
\sigma_{y}, \sigma_{z} & =\text { diffusion coefficients in the } y \text { and } z \text { direction, respectively } \\
Q & =\text { continuous release rate }\left(\mathrm{Ci} \mathrm{s}^{-1}\right) .
\end{array}
$$

For a release of finite duration, the TIC is found by integrating Equation (A-1). Because there are no time terms in Equation (A-1), the TIC is simply $\chi$ times the integration time. Assuming transport time from source to receptor is short relative to release time, then the TIC is simply Equation (A-1) replacing the release rate $(\mathrm{Q})$ with the quantity released over the integration time $(\mathrm{q}$, in $\mathrm{Ci})$.

\section{A-1.1 Release Height}

The release height is the physical height of the release plus plume rise due to momentum or buoyant rise. Both momentum and buoyant rise are calculated and the higher of the two is used in the calculations.

Buoyancy flux (F) is given by Equation 3.3 in Turner (1994):

$$
F=\frac{g v d^{2} \Delta T}{4 T_{s}}
$$

where

$$
\begin{aligned}
& g=\text { acceleration due to gravity }\left(9.8 \mathrm{~m} \mathrm{~s}^{-2}\right) \\
& v=\text { stack-gas exit velocity }\left(\mathrm{m} \mathrm{s}^{-1}\right)
\end{aligned}
$$


$d=$ inside stack diameter at top of stack (m)

$\Delta \mathrm{T}=$ stack gas temperature minus ambient temperature $(\mathrm{K})$

$T_{s}=$ stack gas exit temperature $(\mathrm{K})$.

For unstable or neutral conditions, the buoyant rise is given by

$$
\begin{gathered}
\Delta H=\frac{21.425 F^{3 / 4}}{u_{h}}, \quad F<55 \\
\Delta H=\frac{38.71 F^{3 / 5}}{u_{h}}, \quad F \geq 55
\end{gathered}
$$

where $u_{h}=$ the wind speed at the top of the stack $\left(\mathrm{m} \mathrm{s}^{-1}\right)$.

For unstable or neutral conditions, the momentum rise is given by

$$
\Delta H=\frac{3 d v}{u_{h}} \text {. }
$$

For stable conditions, the buoyant rise is a function of the stability parameter (s).

$$
\begin{gathered}
s=\frac{g \frac{d \theta}{d z}}{T} \\
\frac{d \theta}{d z}=\frac{d T}{d z}+\Gamma
\end{gathered}
$$

where $\Gamma$ is the adiabatic lapse rate $(0.0098 \mathrm{~K} / \mathrm{m})$. The final buoyant rise is given by two equations where the lower of the two values is used

$$
\begin{aligned}
& \Delta H=2.6\left[\frac{F}{u_{h} S}\right]^{1 / 3} \\
& \Delta H=4 F^{1 / 4} s^{-3 / 8} .
\end{aligned}
$$

Momentum rise in stable conditions is

$$
\Delta H=1.5\left[\frac{v^{2} d^{2} T}{4 T_{s} u_{h}}\right]^{1 / 3} s^{-1 / 6} .
$$

Momentum rise under stable conditions is also calculated using Equation A-4 and the lower of the two values is used.

\section{A-1.2 Diffusion Coefficients}

The diffusion coefficients used in this assessment were the Briggs Urban coefficients described in Turner (1994). Both the Pasquill-Gifford and Briggs dispersion coefficients were run in the model and compared with results from CALPUFF. The Briggs dispersion coefficients produced doses much closer to those of CALPUFF compared to the Pasquill-Gifford dispersion coefficients (Table A-1). For these reasons, the Briggs dispersion coefficients were used. 
Table A-1. Am-241 inhalation dose and TIC for a release of 6.907E+07 pCi from CPP-1774 with a 1hour release time.

\begin{tabular}{|c|c|c|c|c|c|c|}
\hline Sampler & Distance & Bearing & $\begin{array}{c}\text { Gaussian } \\
\text { Plume Dose } \\
\text { (mrem) }\end{array}$ & $\begin{array}{l}\text { CALPUFF } \\
\text { Dose } \\
\text { (mrem) }\end{array}$ & $\begin{array}{c}\text { Gaussian } \\
\text { Plume TIC } \\
\left(\text { pCi-hour } / \mathrm{m}^{3}\right)\end{array}$ & $\begin{array}{c}\text { CALPUFF TIC } \\
\left(\mathrm{pCi}-\text { hour } / \mathrm{m}^{3}\right)\end{array}$ \\
\hline \multicolumn{7}{|c|}{ Briggs Dispersion Coefficients } \\
\hline BEA-TRA & 3,040 & 304 & 0.182 & 0.165 & 0.661 & 0.5993 \\
\hline BEA-CPP & 343 & 290 & 3.945 & 2.511 & 14.3 & 9.124 \\
\hline BEA-INTEC & 1,050 & 18 & 0.736 & 0.5738 & 2.67 & 2.09 \\
\hline BEA-RTC & 3,161 & 318 & 0.1417 & 0.184 & 0.515 & 0.669 \\
\hline \multicolumn{7}{|c|}{ Pasquill-Gifford Dispersion Coefficients } \\
\hline BEA-TRA & 3,040 & 304 & 0.409 & 0.165 & 1.49 & 0.5993 \\
\hline BEA-CPP & 343 & 290 & 6.25 & 2.511 & 22.7 & 9.124 \\
\hline BEA-INTEC & 1,050 & 18 & 6.47 & 0.5738 & 23.5 & 2.09 \\
\hline BEA-RTC & 3,161 & 318 & 0.6129 & 184 & 2.23 & 0.669 \\
\hline
\end{tabular}

\section{A-1.3 Stability Class}

Stability class was determined using the solar radiation-delta-temperature method described in EPA (2000).

\section{A-1.4 Coordinate Transformations}

The coordinates of each of the receptors $\left(x_{r e c}, y_{\text {rec }}\right)$ located at distance $r$ and azimuth $\phi$ from the source were calculated as follows:

$$
\begin{aligned}
& x_{\text {rec }}=\sin (\phi) r+x_{\text {source }} \\
& y_{\text {rec }}=\cos (\phi) r+y_{\text {source }}
\end{aligned}
$$

where $x_{\text {source }}$ and $y_{\text {source }}$ are the Cartesian coordinates of the source. In most cases, the wind does not blow at the same azimuth direction as the receptor is from the source. The downwind distance $x$ and crosswind distance $y$ of the receptor located at azimuth $\phi$ and a wind vector $\psi$ is given by (see Figure A-1)

$$
\begin{aligned}
& x=r-a b s\left(x_{\text {rec }}-x_{\text {wind }}\right) \\
& y=r \sin (\phi-\psi) \\
& x_{\text {wind }}=\sin (\psi) r+x_{\text {source }} .
\end{aligned}
$$






Figure A-1. Diagram showing downwind distance and crosswind distance for a receptor located at azimuth 45 degrees and wind vector azimuth of 58 degrees.

\section{A-1.5 References}

EPA, 2000, Meteorological Monitoring Guidance for Regulatory Modeling Applications, EPA-454/R-99005, U.S. Environmental Protection Agency, Office of Air Quality and Planning Standards.

Turner, D. B., 1994, Workbook of Atmospheric Dispersion Estimates, CRC Press, Boca Raton, Florida. 


\section{Appendix B Tritium Sampling and Analysis}

This appendix contains a description of tritium sampling methods and how the MDA and sampler flow rates are determined. Tritium detection is reported in terms of the minimum detectable concentration in atmospheric water. The tritium sampler collects atmospheric water, which involves a 9-mL sample of collected water being taken and analyzed for tritium. Parameters needed for the FD analysis are sampler flow rate, sample time, and MDA. Average flow rates, water collection volumes, sampling time, and MDA are derived from the data in Table B-1. Other assumptions and data are as follows:

Data:

Sampler flow rate for atmospheric moisture:

$0.019 \mathrm{~m}^{3} /$ hour $=19 \mathrm{~L} /$ hour

Water collection amount during sampling period:

$50 \mathrm{~mL}(0.05 \mathrm{~L})$

Sampling time:

27 days (648 hours)

Absolute humidity:

$0.00345 \mathrm{~g} / \mathrm{L}$

Amount of water analyzed:

$9 \mathrm{~mL}$

Collection efficiency of water vapor:

$100 \%$

Minimum detectable concentration for tritium in water: $83.9 \mathrm{pCi} / \mathrm{L}$.

Table B-1. Tritium sampler data from Atomic City for sampling during 2014.

\begin{tabular}{cccccccc}
\hline Date On & Date Off & $\begin{array}{c}\text { Water } \\
\text { Collected }(\mathbf{m L})\end{array}$ & $\begin{array}{c}\text { Flow Meter } \\
\text { On }\end{array}$ & $\begin{array}{c}\text { Flow Meter } \\
\text { Off }\end{array}$ & $\begin{array}{c}\text { Air Volume } \\
\left(\mathbf{m}^{\mathbf{3}}\right)\end{array}$ & $\begin{array}{c}\text { Days } \\
\text { Sampled }\end{array}$ & $\begin{array}{c}\text { Flow Rate } \\
\left(\mathbf{m}^{\mathbf{3}} / \mathbf{h r}\right)\end{array}$ \\
\hline $12 / 31 / 13$ & $2 / 12 / 14$ & 52.1 & 672.167 & 691.913 & 19.746 & 43 & 0.01913 \\
$2 / 12 / 14$ & $3 / 12 / 14$ & 56 & 691.913 & 706.214 & 14.301 & 28 & 0.02128 \\
$3 / 12 / 14$ & $4 / 17 / 14$ & 43 & 706.214 & 722.245 & 16.031 & 36 & 0.01855 \\
$4 / 17 / 14$ & $5 / 14 / 14$ & 43.9 & 722.245 & 734.092 & 11.847 & 27 & 0.01828 \\
$5 / 14 / 14$ & $6 / 11 / 14$ & 47.8 & 734.092 & 745.802 & 11.71 & 28 & 0.01743 \\
$6 / 11 / 14$ & $7 / 9 / 14$ & 42.4 & 745.802 & 754.139 & 8.337 & 28 & 0.01241 \\
$7 / 9 / 14$ & $7 / 30 / 14$ & 52.2 & 754.139 & 763.47 & 9.331 & 21 & 0.01851 \\
$7 / 30 / 14$ & $8 / 13 / 14$ & 52.7 & 763.47 & 769.756 & 6.286 & 14 & 0.01871 \\
$8 / 13 / 14$ & $8 / 27 / 14$ & 53.1 & 769.756 & 776.34 & 6.584 & 14 & 0.01960 \\
$8 / 27 / 14$ & $9 / 17 / 14$ & 43.5 & 776.34 & 785.597 & 9.257 & 21 & 0.01837 \\
$9 / 17 / 14$ & $10 / 1 / 14$ & 51.5 & 785.597 & 792.841 & 7.244 & 14 & 0.02156 \\
$10 / 1 / 14$ & $10 / 29 / 14$ & 53.9 & 792.841 & 808.369 & 15.528 & 28 & 0.02311 \\
$10 / 29 / 14$ & $12 / 10 / 14$ & 57.2 & 808.369 & 828.696 & 20.327 & 42 & 0.02017 \\
$12 / 10 / 14$ & $1 / 14 / 15$ & 47.3 & 828.696 & 849.113 & 20.417 & 35 & 0.02431 \\
& Average & 49.75 & & & & 27 & 0.01939 \\
\hline
\end{tabular}

For a 9-mL sample taken for analysis, the MDA can be calculated as follows:

$83.6 \mathrm{pCi} / \mathrm{L} \times 1 \mathrm{~L} / 1000 \mathrm{~mL} \times 9 \mathrm{~mL}=0.752 \mathrm{pCi}$. 


\section{Appendix C Frequency of Detection Output}

This appendix contains the FREQD program output for the resident scenario using the optimized existing network.

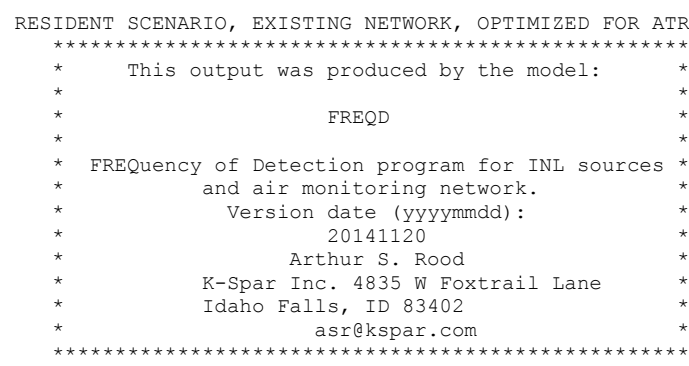

Date: 05/16/2015 Time: 21:21:58.905

Input File: freqd.par

\begin{tabular}{|c|c|c|c|c|c|c|c|c|c|}
\hline \multicolumn{10}{|c|}{$\begin{array}{l}\text { FreqD.f95 - Evaluation of existing network for } 168 \text {-hr release yielding } 1 \mathrm{mrem} / \mathrm{yr} \\
\text { Data File:../././TICSALL/ATR_combine.txt } \\
67\end{array}$} \\
\hline BEA-TRA & 3.398 & 168 & 1 & 1 & sampname, & , flowr, & , rtime, & , onsite, & incsamp \\
\hline $\mathrm{BEA}-\mathrm{CPP}$ & 3.398 & 168 & 1 & 1 & sampname, & , flowr, & , rtime, & , onsite, & incsamp \\
\hline BEA-RWMC & 3.39 & 168 & 1 & 1 & sampname, & , flowr, & , rtime, & , onsite, & incsamp \\
\hline BEA-VAN & 3.398 & 168 & 1 & 1 & sampname, & , flowr, & , rtime, & , onsite, & incsamp \\
\hline$B E A-I R C$ & 3.398 & 168 & 1 & 1 & sampname, & , flowr, & , rtime, & , onsite, & incsamp \\
\hline BEA-BLKFT & 3.3 & 168 & 1 & 1 & sampname, & , flowr, & , rtime, & , onsite, & incsamp \\
\hline BEA-SMC & 3.398 & 168 & 1 & 1 & sampname, & , flowr, & , rtime, & , onsite, & incsamp \\
\hline BEA-GATE & 3.39 & 168 & 1 & 1 & sampname, & , flowr, & , rtime, & , onsite, & incsamp \\
\hline BEA-ARA & 3.398 & 168 & 1 & 0 & sampname, & , flowr, & , rtime, & , onsite, & incsamp \\
\hline BEA-REST & 3.39 & 168 & 1 & 1 & sampname, & , flowr, & , rtime, & , onsite, & incsamp \\
\hline $\mathrm{BEA}-\mathrm{IF}$ & 3.398 & 168 & 1 & 1 & sampname, & , flowr, & , rtime, & , onsite, & incsamp \\
\hline BEA-NRF & 3.398 & 168 & 1 & 1 & sampname, & , flowr, & , rtime, & , onsite, & incsamp \\
\hline BEA-RTC & 3.398 & 168 & 1 & 1 & sampname, & , flowr, & , rtime, & , onsite, & incsamp \\
\hline $\mathrm{BEA}-\mathrm{EBR}$ & 3.398 & 168 & 1 & 1 & sampname, & , flowr, & , rtime, & , onsite, & incsamp \\
\hline BEA-MFC & 3.398 & 168 & 1 & 1 & sampname, & , flowr, & , rtime, & , onsite, & incsamp \\
\hline BEA-SUGAR & 3.3 & 168 & 1 & 1 & sampname, & , flowr, & , rtime, & , onsite, & incsamp \\
\hline $\mathrm{BEA}-\mathrm{PBF}$ & 3.398 & 168 & 1 & 0 & sampname, & , flowr, & , rtime, & , onsite, & incsamp \\
\hline BEA-INTEC & 3.3 & 168 & 1 & 1 & sampname, & , flowr, & , rtime, & , onsite, & incsamp \\
\hline $\mathrm{BEA}-\mathrm{CFA}$ & 3.398 & 168 & 1 & 1 & sampname, & , flowr, & , rtime, & , onsite, & incsamp \\
\hline BEA-EFS & 3.398 & 168 & 1 & 1 & sampname, & , flowr, & , rtime, & , onsite, & incsamp \\
\hline BEA-CRATEF & 3. & 168 & 1 & 1 & sampname, & , flowr, & , rtime, & , onsite, & incsamp \\
\hline ESER-VAN & 3.39 & 168 & 1 & 1 & sampname, & , flowr, & , rtime, & , onsite, & incsamp \\
\hline ESER-CRA & 3.39 & 168 & 1 & 1 & sampname, & , flowr, & , rtime, & , onsite, & incsamp \\
\hline ESER-ARC & 3.39 & 168 & 1 & 1 & sampname, & , flowr, & , rtime, & , onsite, & incsamp \\
\hline ESER-SUG & 3.39 & 168 & 1 & 1 & sampname, & , flowr, & , rtime, & , onsite, & incsamp \\
\hline ESER-IDA & 3.39 & 168 & 1 & 1 & sampname, & , flowr, & , rtime, & , onsite, & incsamp \\
\hline ESER-DUB & 3.39 & 168 & 1 & 1 & sampname, & flowr, & , rtime, & , onsite, & incsamp \\
\hline ESER-MON & 3.39 & 168 & 1 & 1 & sampname, & , flowr, & , rtime, & , onsite, & incsamp \\
\hline ESER-FAA & 3.39 & 168 & 1 & 0 & sampname, & , flowr, & , rtime, & , onsite, & incsamp \\
\hline ESER-MAI & 3.39 & 168 & 1 & 0 & sampname, & , flowr, & , rtime, & , onsite, & incsamp \\
\hline ESER-EFS & 3.39 & 168 & 1 & 1 & sampname, & , flowr, & , rtime, & , onsite, & incsamp \\
\hline ESER-ATO & 3.39 & 168 & 1 & 1 & sampname, & , flowr, & , rtime, & , onsite, & incsamp \\
\hline ESER-MOU & 3.39 & 168 & 1 & 1 & sampname, & , flowr, & , rtime, & , onsite, & incsamp \\
\hline ESER-BLU & 3.39 & 168 & 1 & 1 & sampname, & , flowr, & , rtime, & , onsite, & incsamp \\
\hline ESER-TER & 3.39 & 168 & 1 & 1 & sampname, & , flowr, & , rtime, & , onsite, & incsamp \\
\hline ESER-HOW & 3.39 & 168 & 1 & 1 & sampname, & , flowr, & , rtime, & , onsite, & incsamp \\
\hline MEI01 & 3998 & 168 & 1 & 0 & ampname, $f$ & flowr, $r$ & rtime, & onsite, & hcsamp \\
\hline MEI02 & .398 & 168 & 1 & 0 & sampname, $f$ & flowr, $r$ & rtime, & onsite, & ncsamp \\
\hline MEI03 & 398 & 168 & 1 & 0 & sampname, $f$ & flowr, $r$ & rtime, & onsite, & ncsamp \\
\hline MEIO 4 & 398 & 168 & 1 & 0 & sampname, $f$ & flowr, $r$ & rtime, & onsite, & incsamp \\
\hline MEI05 & 398 & 168 & 1 & 0 & sampname, $f$ & flowr, $r$ & rtime, & onsite, i & incsamp \\
\hline MEI0 6 & 398 & 168 & 1 & 0 & sampname, $f$ & flowr, $r$ & rtime, & onsite, i & incsamp \\
\hline MEI07 & 398 & 168 & 1 & 0 & sampname, $f$ & flowr, $r$ & rtime, & onsite, i & incsamp \\
\hline MEI08 & 398 & 168 & 1 & 0 & sampname, & flowr, $r$ & rtime, & onsite, i & incsamp \\
\hline MEI09 & .398 & 168 & 1 & 0 & sampname, $f$ & flowr, $r$ & rtime, & onsite, i & incsamp \\
\hline MEI 10 & 398 & 168 & 1 & 0 & sampname, $f$ & flowr, $r$ & rtime, & onsite, i & incsamp \\
\hline MEI11 & .398 & 168 & 1 & 0 & sampname, & flowr, $r$ & rtime, & onsite, i & incsamp \\
\hline $\operatorname{MEI} 12$ & 398 & 168 & 1 & 0 & sampname, $f$ & flowr, $r$ & rtime, & onsite, i & incsamp \\
\hline MEI13 & 398 & 168 & 1 & 0 & sampname, $f$ & flowr, $r$ & rtime, & onsite, i & incsamp \\
\hline $\operatorname{MEI} 14$ & .398 & 168 & 1 & 0 & sampname, $f$ & flowr, $r$ & rtime, & onsite, i & incsamp \\
\hline MEI15 & .398 & 168 & 1 & 0 & sampname, $f$ & flowr, $r$ & rtime, & onsite, i & incsamp \\
\hline MEI16 & 3.398 & 168 & 1 & 0 & sampname, $f$ & flowr, $r$ & rtime, & onsite, i & incsamp \\
\hline MEI17 & 398 & 168 & 1 & 0 & sampname, $f$ & flowr, $r$ & rtime, & onsite, i & incsamp \\
\hline $\operatorname{MEI} 18$ & .398 & 168 & 1 & 0 & sampname, $f$ & flowr, $r$ & rtime, & onsite, i & incsamp \\
\hline MEI19 & .398 & 168 & 1 & 0 & sampname, $f$ & flowr, $r$ & rtime, & onsite, i & incsamp \\
\hline MEI20 & .398 & 168 & 1 & 0 & sampname, $f$ & flowr, $r$ & rtime, & onsite, i & incsamp \\
\hline MEI21 & 398 & 168 & 1 & 0 & sampname, $f$ & flowr, $r$ & rtime, & onsite, i & incsamp \\
\hline MEI22 & .398 & 168 & 1 & 0 & sampname, $f$ & flowr, $r$ & rtime, & onsite, i & incsamp \\
\hline MEI23 & 398 & 168 & 1 & 0 & sampname, $f$ & flowr, $r$ & rtime, & onsite, i & incsamp \\
\hline $\operatorname{MEI} 24$ & 398 & 168 & 1 & 0 & sampname, $f$ & flowr, $r$ & rtime, & onsite, i & incsamp \\
\hline
\end{tabular}




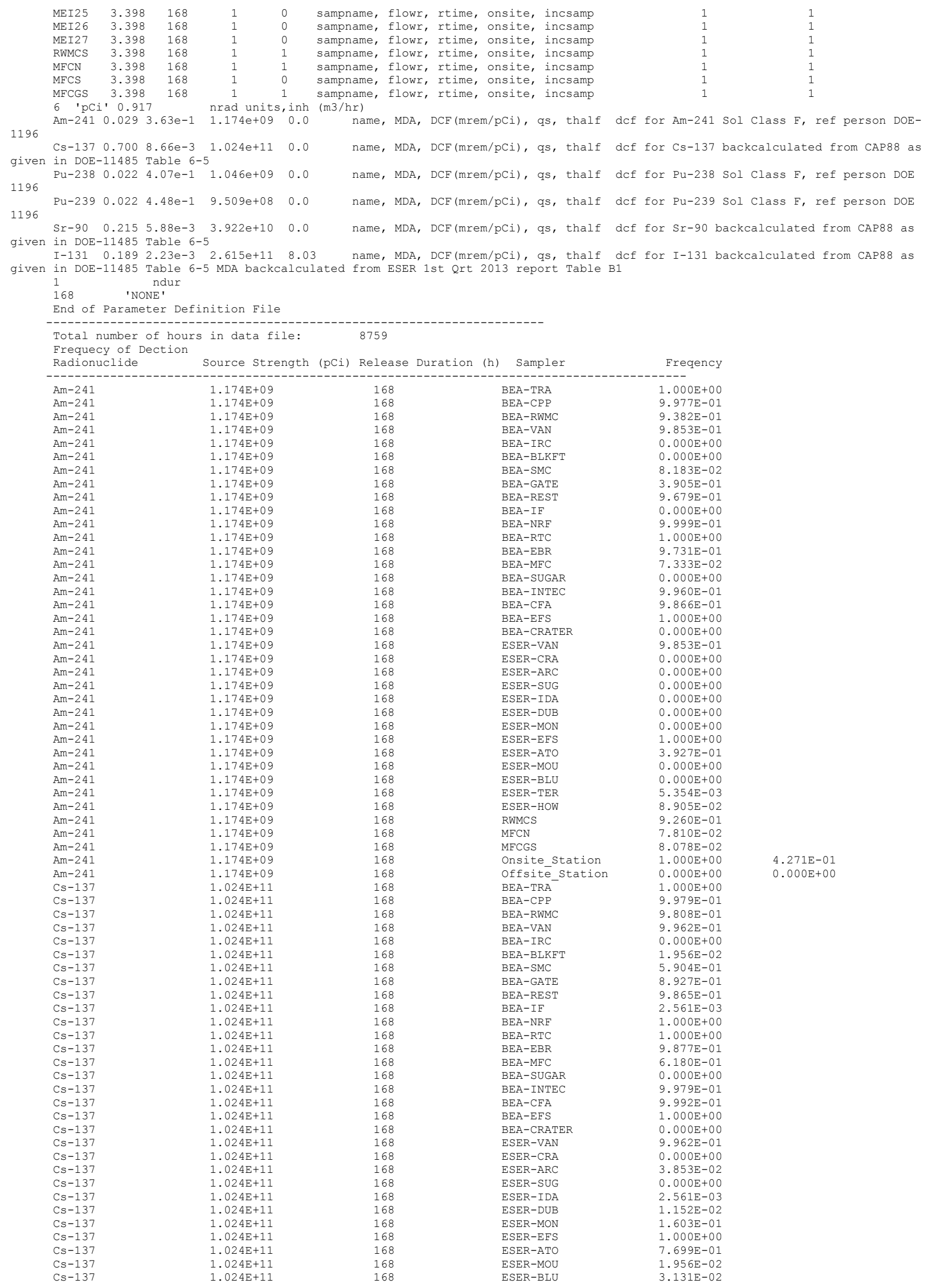




\begin{tabular}{|c|c|c|c|}
\hline Cs -137 & $1.024 \mathrm{E}+11$ & 168 & ESER-TER \\
\hline Cs -137 & $1.024 \mathrm{E}+11$ & 168 & ESER-HOW \\
\hline $\mathrm{Cs}-137$ & $1.024 \mathrm{E}+11$ & 168 & RWMCS \\
\hline Cs -137 & $1.024 \mathrm{E}+11$ & 168 & $\mathrm{MFCN}$ \\
\hline Cs -137 & $1.024 \mathrm{E}+11$ & 168 & MFCGS \\
\hline Cs -137 & $1.024 \mathrm{E}+11$ & 168 & Onsite Station \\
\hline Cs -137 & $1.024 \mathrm{E}+11$ & 168 & Offsitéstation \\
\hline $\mathrm{Pu}-238$ & $1.046 \mathrm{E}+09$ & 168 & BEA-TRA \\
\hline $\mathrm{Pu}-238$ & $1.046 \mathrm{E}+09$ & 168 & $\mathrm{BEA}-\mathrm{CPP}$ \\
\hline $\mathrm{Pu}-238$ & $1.046 \mathrm{E}+09$ & 168 & BEA-RWMC \\
\hline Pu-238 & $1.046 \mathrm{E}+09$ & 168 & BEA-VAN \\
\hline Pu-238 & $1.046 \mathrm{E}+09$ & 168 & $B E A-I R C$ \\
\hline Pu-238 & $1.046 \mathrm{E}+09$ & 168 & BEA-BLKFT \\
\hline $\mathrm{Pu}-238$ & $1.046 \mathrm{E}+09$ & 168 & BEA-SMC \\
\hline $\mathrm{Pu}-238$ & $1.046 \mathrm{E}+09$ & 168 & BEA-GATE \\
\hline $\mathrm{Pu}-238$ & $1.046 \mathrm{E}+09$ & 168 & BEA-REST \\
\hline Pu-238 & $1.046 \mathrm{E}+09$ & 168 & $B E A-I F$ \\
\hline Pu-238 & $1.046 \mathrm{E}+09$ & 168 & BEA-NRF \\
\hline Pu -238 & $1.046 \mathrm{E}+09$ & 168 & BEA-RTC \\
\hline $\mathrm{Pu}-238$ & $1.046 \mathrm{E}+09$ & 168 & $\mathrm{BEA}-\mathrm{EBR}$ \\
\hline $\mathrm{Pu}-238$ & $1.046 \mathrm{E}+09$ & 168 & BEA-MFC \\
\hline $\mathrm{Pu}-238$ & $1.046 \mathrm{E}+09$ & 168 & BEA-SUGAR \\
\hline $\mathrm{Pu}-238$ & $1.046 \mathrm{E}+09$ & 168 & BEA-INTEC \\
\hline Pu-238 & $1.046 \mathrm{E}+09$ & 168 & $\mathrm{BEA}-\mathrm{CFA}$ \\
\hline $\mathrm{Pu}-238$ & $1.046 \mathrm{E}+09$ & 168 & BEA-EFS \\
\hline $\mathrm{Pu}-238$ & $1.046 \mathrm{E}+09$ & 168 & BEA-CRATER \\
\hline $\mathrm{Pu}-238$ & $1.046 \mathrm{E}+09$ & 168 & ESER-VAN \\
\hline $\mathrm{Pu}-238$ & $1.046 \mathrm{E}+09$ & 168 & ESER-CRA \\
\hline Pu-238 & $1.046 \mathrm{E}+09$ & 168 & ESER-ARC \\
\hline Pu-238 & $1.046 \mathrm{E}+09$ & 168 & ESER-SUG \\
\hline Pu-238 & $1.046 \mathrm{E}+09$ & 168 & ESER-IDA \\
\hline Pu-238 & $1.046 \mathrm{E}+09$ & 168 & ESER-DUB \\
\hline Pu-238 & $1.046 \mathrm{E}+09$ & 168 & ESER-MON \\
\hline $\mathrm{Pu}-238$ & $1.046 \mathrm{E}+09$ & 168 & ESER-EFS \\
\hline Pu-238 & $1.046 \mathrm{E}+09$ & 168 & ESER-ATO \\
\hline $\mathrm{Pu}-238$ & $1.046 \mathrm{E}+09$ & 168 & ESER-MOU \\
\hline $\mathrm{Pu}-238$ & $1.046 \mathrm{E}+09$ & 168 & ESER-BLU \\
\hline $\mathrm{Pu}-238$ & $1.046 \mathrm{E}+09$ & 168 & ESER-TER \\
\hline Pu-238 & $1.046 \mathrm{E}+09$ & 168 & ESER-HOW \\
\hline $\mathrm{Pu}-238$ & $1.046 \mathrm{E}+09$ & 168 & RWMCS \\
\hline $\mathrm{Pu}-238$ & $1.046 \mathrm{E}+09$ & 168 & MFCN \\
\hline $\mathrm{Pu}-238$ & $1.046 \mathrm{E}+09$ & 168 & MFCGS \\
\hline $\mathrm{Pu}-238$ & $1.046 \mathrm{E}+09$ & 168 & Onsite Station \\
\hline Pu-238 & $1.046 \mathrm{E}+09$ & 168 & offsitè Station \\
\hline $\mathrm{Pu}-239$ & $9.509 \mathrm{E}+08$ & 168 & BEA-TRA \\
\hline Pu-239 & $9.509 \mathrm{E}+08$ & 168 & $\mathrm{BEA}-\mathrm{CPP}$ \\
\hline $\mathrm{Pu}-239$ & $9.509 \mathrm{E}+08$ & 168 & $\mathrm{BEA}-\mathrm{RWMC}$ \\
\hline $\mathrm{Pu}-239$ & $9.509 \mathrm{E}+08$ & 168 & BEA-VAN \\
\hline Pu-239 & $9.509 \mathrm{E}+08$ & 168 & BEA-IRC \\
\hline Pu-239 & $9.509 \mathrm{E}+08$ & 168 & BEA-BLKFT \\
\hline Pu-239 & $9.509 \mathrm{E}+08$ & 168 & $\mathrm{BEA}-\mathrm{SMC}$ \\
\hline $\mathrm{Pu}-239$ & $9.509 \mathrm{E}+08$ & 168 & BEA-GATE \\
\hline Pu-239 & $9.509 \mathrm{E}+08$ & 168 & BEA-REST \\
\hline Pu-239 & $9.509 \mathrm{E}+08$ & 168 & $\mathrm{BEA}-\mathrm{IF}$ \\
\hline $\mathrm{Pu}-239$ & $9.509 \mathrm{E}+08$ & 168 & $\mathrm{BEA}-\mathrm{NRF}$ \\
\hline $\mathrm{Pu}-239$ & $9.509 \mathrm{E}+08$ & 168 & BEA-RTC \\
\hline Pu-239 & $9.509 \mathrm{E}+08$ & 168 & BEA-EBR \\
\hline $\mathrm{Pu}-239$ & $9.509 \mathrm{E}+08$ & 168 & BEA-MFC \\
\hline Pu-239 & $9.509 \mathrm{E}+08$ & 168 & BEA-SUGAR \\
\hline Pu-239 & $9.509 \mathrm{E}+08$ & 168 & BEA-INTEC \\
\hline $\mathrm{Pu}-239$ & $9.509 \mathrm{E}+08$ & 168 & $\mathrm{BEA}-\mathrm{CFA}$ \\
\hline Pu-239 & $9.509 \mathrm{E}+08$ & 168 & BEA-EFS \\
\hline Pu-239 & $9.509 \mathrm{E}+08$ & 168 & BEA-CRATER \\
\hline Pu-239 & $9.509 \mathrm{E}+08$ & 168 & ESER-VAN \\
\hline $\mathrm{Pu}-239$ & $9.509 \mathrm{E}+08$ & 168 & ESER-CRA \\
\hline $\mathrm{Pu}-239$ & $9.509 \mathrm{E}+08$ & 168 & ESER-ARC \\
\hline $\mathrm{Pu}-239$ & $9.509 \mathrm{E}+08$ & 168 & ESER-SUG \\
\hline Pu-239 & $9.509 \mathrm{E}+08$ & 168 & ESER-IDA \\
\hline $\mathrm{Pu}-239$ & $9.509 \mathrm{E}+08$ & 168 & ESER-DUB \\
\hline Pu-239 & $9.509 \mathrm{E}+08$ & 168 & ESER-MON \\
\hline Pu-239 & $9.509 \mathrm{E}+08$ & 168 & ESER-EFS \\
\hline $\mathrm{Pu}-239$ & $9.509 \mathrm{E}+08$ & 168 & ESER-ATO \\
\hline Pu-239 & $9.509 \mathrm{E}+08$ & 168 & ESER-MOU \\
\hline Pu-239 & $9.509 \mathrm{E}+08$ & 168 & ESER-BLU \\
\hline Pu-239 & $9.509 \mathrm{E}+08$ & 168 & ESER-TER \\
\hline $\mathrm{Pu}-239$ & $9.509 \mathrm{E}+08$ & 168 & ESER-HOW \\
\hline Pu-239 & $9.509 \mathrm{E}+08$ & 168 & RWMCS \\
\hline Pu-239 & $9.509 \mathrm{E}+08$ & 168 & $\mathrm{MFCN}$ \\
\hline Pu-239 & $9.509 \mathrm{E}+08$ & 168 & MFCGS \\
\hline $\mathrm{Pu}-239$ & $9.509 \mathrm{E}+08$ & 168 & Onsite Station \\
\hline Pu-239 & $9.509 \mathrm{E}+08$ & 168 & Offsite Station \\
\hline $\mathrm{Sr}-90$ & $3.922 \mathrm{E}+10$ & 168 & BEA-TRA \\
\hline $\mathrm{Sr}-90$ & $3.922 \mathrm{E}+10$ & 168 & $\mathrm{BEA}-\mathrm{CPP}$ \\
\hline $\mathrm{Sr}-90$ & $3.922 \mathrm{E}+10$ & 168 & BEA-RWMC \\
\hline $\mathrm{Sr}-90$ & $3.922 \mathrm{E}+10$ & 168 & BEA-VAN \\
\hline $\mathrm{Sr}-90$ & $3.922 \mathrm{E}+10$ & 168 & BEA-IRC \\
\hline $\mathrm{Sr}-90$ & $3.922 \mathrm{E}+10$ & 168 & BEA-BLKFT \\
\hline $\mathrm{Sr}-90$ & $3.922 \mathrm{E}+10$ & 168 & BEA-SMC \\
\hline $\mathrm{Sr}-90$ & $3.922 \mathrm{E}+10$ & 168 & BEA-GATE \\
\hline $\mathrm{Sr}-90$ & $3.922 \mathrm{E}+10$ & 168 & BEA-REST \\
\hline $\mathrm{Sr}-90$ & $3.922 \mathrm{E}+10$ & 168 & $\mathrm{BEA}-\mathrm{IF}$ \\
\hline $\mathrm{Sr}-90$ & $3.922 \mathrm{E}+10$ & 168 & BEA-NRF \\
\hline $\mathrm{Sr}-90$ & $3.922 E+10$ & 168 & BEA-RTC \\
\hline $\mathrm{Sr}-90$ & $3.922 \mathrm{E}+10$ & 168 & BEA-EBR \\
\hline $\mathrm{Sr}-90$ & $3.922 \mathrm{E}+10$ & 168 & BEA-MFC \\
\hline
\end{tabular}




\begin{tabular}{|c|c|c|c|c|c|}
\hline Sr -90 & $3.922 \mathrm{E}+10$ & 168 & BEA-SUGAR & $0.000 \mathrm{E}+00$ & \\
\hline Sr-90 & $3.922 \mathrm{E}+10$ & 168 & BEA-INTEC & $9.979 \mathrm{E}-01$ & \\
\hline Sr -90 & $3.922 \mathrm{E}+10$ & 168 & $\mathrm{BEA}-\mathrm{CFA}$ & $9.993 \mathrm{E}-01$ & \\
\hline $\mathrm{Sr}-90$ & $3.922 \mathrm{E}+10$ & 168 & BEA-EFS & $1.000 \mathrm{E}+00$ & \\
\hline $\mathrm{Sr}-90$ & $3.922 \mathrm{E}+10$ & 168 & BEA-CRATER & $0.000 \mathrm{E}+00$ & \\
\hline $\mathrm{Sr}-90$ & $3.922 \mathrm{E}+10$ & 168 & ESER-VAN & $9.966 \mathrm{E}-01$ & \\
\hline $\mathrm{Sr}-90$ & $3.922 \mathrm{E}+10$ & 168 & ESER-CRA & $0.000 \mathrm{E}+00$ & \\
\hline $\mathrm{Sr}-90$ & $3.922 \mathrm{E}+10$ & 168 & ESER-ARC & $4.353 \mathrm{E}-02$ & \\
\hline $\mathrm{Sr}-90$ & $3.922 \mathrm{E}+10$ & 168 & ESER-SUG & $0.000 \mathrm{E}+00$ & \\
\hline $\mathrm{Sr}-90$ & $3.922 \mathrm{E}+10$ & 168 & ESER-IDA & $1.141 \mathrm{E}-02$ & \\
\hline $\mathrm{Sr}-90$ & $3.922 \mathrm{E}+10$ & 168 & ESER-DUB & $2.794 \mathrm{E}-02$ & \\
\hline $\mathrm{Sr}-90$ & $3.922 \mathrm{E}+10$ & 168 & ESER-MON & $2.326 \mathrm{E}-01$ & \\
\hline$S r-90$ & $3.922 \mathrm{E}+10$ & 168 & ESER-EFS & $1.000 \mathrm{E}+00$ & \\
\hline $\mathrm{Sr}-90$ & $3.922 \mathrm{E}+10$ & 168 & ESER-ATO & $8.248 \mathrm{E}-01$ & \\
\hline $\mathrm{Sr}-90$ & $3.922 \mathrm{E}+10$ & 168 & ESER-MOU & $4.295 \mathrm{E}-02$ & \\
\hline $\mathrm{Sr}-90$ & $3.922 \mathrm{E}+10$ & 168 & ESER-BLU & $6.635 \mathrm{E}-02$ & \\
\hline $\mathrm{Sr}-90$ & $3.922 \mathrm{E}+10$ & 168 & ESER-TER & $4.502 \mathrm{E}-01$ & \\
\hline Sr -90 & $3.922 \mathrm{E}+10$ & 168 & ESER-HOW & $6.738 \mathrm{E}-01$ & \\
\hline $\mathrm{Sr}-90$ & $3.922 \mathrm{E}+10$ & 168 & RWMCS & $9.810 \mathrm{E}-01$ & \\
\hline $\mathrm{Sr}-90$ & $3.922 \mathrm{E}+10$ & 168 & $\mathrm{MFCN}$ & $6.970 \mathrm{E}-01$ & \\
\hline $\mathrm{Sr}-90$ & $3.922 \mathrm{E}+10$ & 168 & MFCGS & $7.006 \mathrm{E}-01$ & \\
\hline $\mathrm{Sr}-90$ & $3.922 \mathrm{E}+10$ & 168 & Onsite Station & $1.000 \mathrm{E}+00$ & $5.739 \mathrm{E}-01$ \\
\hline Sr -90 & $3.922 \mathrm{E}+10$ & 168 & Offsité-Station & $0.000 \mathrm{E}+00$ & $0.000 \mathrm{E}+00$ \\
\hline$I-131$ & $2.615 \mathrm{E}+11$ & 168 & BEA-TRA & $1.000 \mathrm{E}+00$ & \\
\hline$I-131$ & $2.615 \mathrm{E}+11$ & 168 & $\mathrm{BEA}-\mathrm{CPP}$ & $1.000 \mathrm{E}+00$ & \\
\hline I-131 & $2.615 \mathrm{E}+11$ & 168 & $\mathrm{BEA}-\mathrm{RWMC}$ & $9.885 \mathrm{E}-01$ & \\
\hline I-131 & $2.615 \mathrm{E}+11$ & 168 & BEA-VAN & $1.000 \mathrm{E}+00$ & \\
\hline I-131 & $2.615 \mathrm{E}+11$ & 168 & BEA-IRC & $3.797 \mathrm{E}-01$ & \\
\hline I-131 & $2.615 \mathrm{E}+11$ & 168 & BEA-BLKFT & $5.047 \mathrm{E}-01$ & \\
\hline I-131 & $2.615 \mathrm{E}+11$ & 168 & BEA-SMC & $9.875 \mathrm{E}-01$ & \\
\hline I-131 & $2.615 \mathrm{E}+11$ & 168 & $\mathrm{BEA}-\mathrm{GATE}$ & $1.000 \mathrm{E}+00$ & \\
\hline I-131 & $2.615 \mathrm{E}+11$ & 168 & BEA-REST & $9.973 \mathrm{E}-01$ & \\
\hline I-131 & $2.615 \mathrm{E}+11$ & 168 & $\mathrm{BEA}-\mathrm{IF}$ & $4.030 \mathrm{E}-01$ & \\
\hline$I-131$ & $2.615 \mathrm{E}+11$ & 168 & $\mathrm{BEA}-\mathrm{NRF}$ & $1.000 \mathrm{E}+00$ & \\
\hline I-131 & $2.615 \mathrm{E}+11$ & 168 & $\mathrm{BEA}-\mathrm{RTC}$ & $1.000 \mathrm{E}+00$ & \\
\hline$I-131$ & $2.615 \mathrm{E}+11$ & 168 & $\mathrm{BEA}-\mathrm{EBR}$ & $9.970 \mathrm{E}-01$ & \\
\hline$I-131$ & $2.615 \mathrm{E}+11$ & 168 & BEA-MFC & $9.787 \mathrm{E}-01$ & \\
\hline I-131 & $2.615 \mathrm{E}+11$ & 168 & BEA-SUGAR & $2.299 \mathrm{E}-01$ & \\
\hline$I-131$ & $2.615 \mathrm{E}+11$ & 168 & BEA-INTEC & $1.000 \mathrm{E}+00$ & \\
\hline I-131 & $2.615 \mathrm{E}+11$ & 168 & $\mathrm{BEA}-\mathrm{CFA}$ & $1.000 \mathrm{E}+00$ & \\
\hline$I-131$ & $2.615 \mathrm{E}+11$ & 168 & BEA-EFS & $1.000 \mathrm{E}+00$ & \\
\hline I-131 & $2.615 \mathrm{E}+11$ & 168 & BEA-CRATER & $3.650 \mathrm{E}-01$ & \\
\hline I-131 & $2.615 \mathrm{E}+11$ & 168 & ESER-VAN & $1.000 \mathrm{E}+00$ & \\
\hline I-131 & $2.615 \mathrm{E}+11$ & 168 & ESER-CRA & $3.650 \mathrm{E}-01$ & \\
\hline I-131 & $2.615 \mathrm{E}+11$ & 168 & ESER-ARC & $7.288 \mathrm{E}-01$ & \\
\hline I-131 & $2.615 \mathrm{E}+11$ & 168 & ESER-SUG & $2.299 \mathrm{E}-01$ & \\
\hline$I-131$ & $2.615 \mathrm{E}+11$ & 168 & ESER-IDA & $4.030 \mathrm{E}-01$ & \\
\hline I-131 & $2.615 \mathrm{E}+11$ & 168 & ESER-DUB & $6.851 \mathrm{E}-01$ & \\
\hline I-131 & $2.615 \mathrm{E}+11$ & 168 & ESER-MON & $9.080 \mathrm{E}-01$ & \\
\hline I-131 & $2.615 \mathrm{E}+11$ & 168 & ESER-EFS & $1.000 \mathrm{E}+00$ & \\
\hline$I-131$ & $2.615 \mathrm{E}+11$ & 168 & ESER-ATO & $9.848 \mathrm{E}-01$ & \\
\hline I-131 & $2.615 \mathrm{E}+11$ & 168 & ESER-MOU & $5.046 \mathrm{E}-01$ & \\
\hline$I-131$ & $2.615 \mathrm{E}+11$ & 168 & ESER-BLU & $6.633 \mathrm{E}-01$ & \\
\hline I-131 & $2.615 \mathrm{E}+11$ & 168 & ESER-TER & $9.531 \mathrm{E}-01$ & \\
\hline$I-131$ & $2.615 \mathrm{E}+11$ & 168 & ESER-HOW & $9.591 \mathrm{E}-01$ & \\
\hline$I-131$ & $2.615 \mathrm{E}+11$ & 168 & RWMCS & $9.884 \mathrm{E}-01$ & \\
\hline I-131 & $2.615 \mathrm{E}+11$ & 168 & $\mathrm{MFCN}$ & $9.792 \mathrm{E}-01$ & \\
\hline I-131 & $2.615 \mathrm{E}+11$ & 168 & MFCGS & $9.750 \mathrm{E}-01$ & \\
\hline I-131 & $2.615 \mathrm{E}+11$ & 168 & Onsite_Station & $1.000 \mathrm{E}+00$ & $8.045 E-01$ \\
\hline$I-131$ & $2.615 \mathrm{E}+11$ & 168 & Offsite_station & $0.000 \mathrm{E}+00$ & $0.000 \mathrm{E}+00$ \\
\hline
\end{tabular}

RESIDENT SCENARIO, EXISTING NETWORK, OPTIMIZED FOR CFA-625

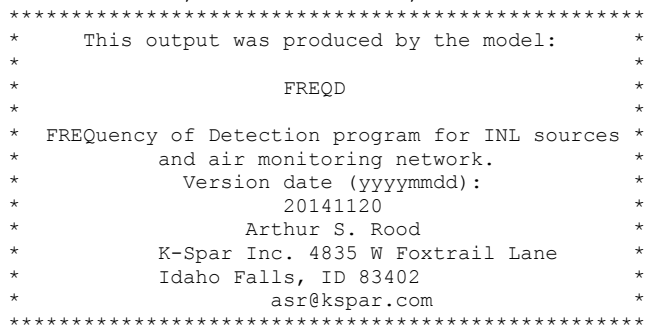

Date: 05/16/2015 Time: $21: 22: 28.223$

Input File: freqd.par

START OF PARAMETER DEFINITION FILE

FreqD.f95 - Evaluation of existing network for 168-hr release yielding $1 \mathrm{mrem} / \mathrm{yr}$ Data File:../.././TICSALL/CFA-625 combine.txt

67

$\begin{array}{lcccccc}\text { BEA-TRA } & 3.398 & 168 & 1 & 1 & \text { sampname, flowr, rtime, onsite, incsamp } \\ \text { BEA-CPP } & 3.398 & 168 & 1 & 1 & \text { sampname, flowr, rtime, onsite, incsamp } \\ \text { BEA-RWMC } & 3.398 & 168 & 1 & 1 & \text { sampname, flowr, rtime, onsite, incsamp } \\ \text { BEA-VAN } & 3.398 & 168 & 1 & 1 & \text { sampname, flowr, rtime, onsite, incsamp } \\ \text { BEA-IRC } & 3.398 & 168 & 1 & 1 & \text { sampname, flowr, rtime, onsite, incsamp } \\ \text { BEA-BLKFT } & 3.398 & 168 & 1 & 1 & \text { sampname, flowr, rtime, onsite, incsamp } \\ \text { BEA-SMC } & 3.398 & 168 & 1 & 1 & \text { sampname, flowr, rtime, onsite, incsamp } \\ \text { BEA-GATE } & 3.398 & 168 & 1 & 1 & \text { sampname, flowr, rtime, onsite, incsamp } \\ \text { BEA-ARA } & 3.398 & 168 & 1 & 0 & \text { sampname, flowr, rtime, onsite, incsamp } \\ \text { BEA-REST } & 3.398 & 168 & 1 & 1 & \text { sampname, flowr, rtime, onsite, incsamp } \\ \text { BEA-IF } & 3.398 & 168 & 1 & 1 & \text { sampname, flowr, rtime, onsite, incsamp }\end{array}$




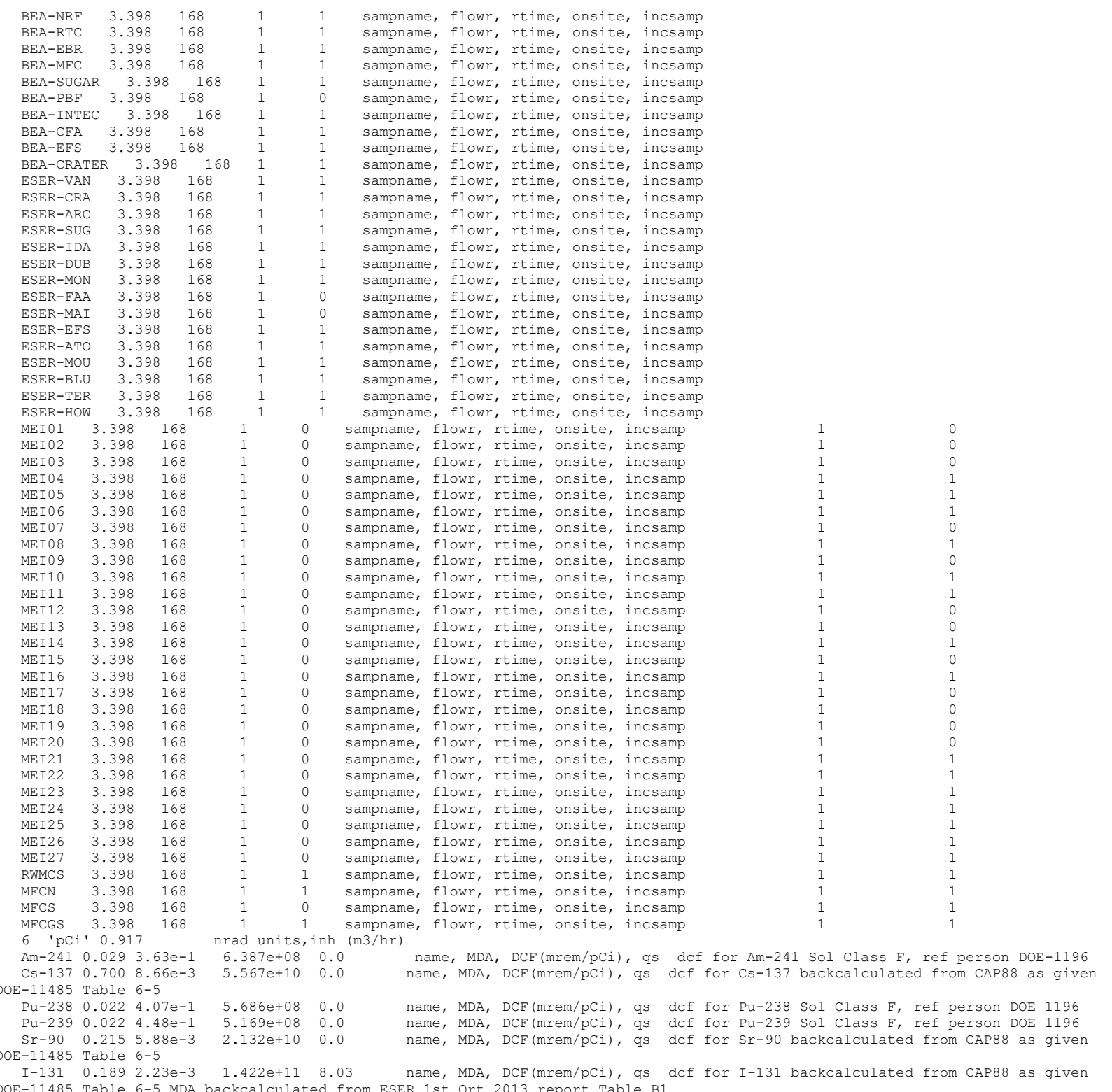

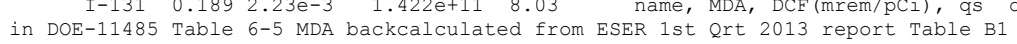
168 ndur

End of Parameter Definition File

Total number of hours in data file:

Frequecy of Dection

Radionuclide Source Strength (pCi) Release Duration (h) Sampler

Freqency

\begin{tabular}{|c|c|c|c|c|}
\hline$A m-241$ & $6.387 E+08$ & 168 & $\mathrm{BEA}-\mathrm{TRA}$ & $7.823 \mathrm{E}-01$ \\
\hline$A m-241$ & $6.387 \mathrm{E}+08$ & 168 & $\mathrm{BEA}-\mathrm{CPP}$ & $9.859 \mathrm{E}-01$ \\
\hline$A m-241$ & $6.387 E+08$ & 168 & BEA-RWMC & $6.173 \mathrm{E}-01$ \\
\hline$A m-241$ & $6.387 \mathrm{E}+08$ & 168 & BEA-VAN & $8.814 \mathrm{E}-01$ \\
\hline $\mathrm{Am}-241$ & $6.387 \mathrm{E}+08$ & 168 & BEA-IRC & $0.000 \mathrm{E}+00$ \\
\hline$A m-241$ & $6.387 \mathrm{E}+08$ & 168 & BEA-BLKFT & $0.000 \mathrm{E}+00$ \\
\hline$A m-241$ & $6.387 \mathrm{E}+08$ & 168 & BEA-SMC & $0.000 \mathrm{E}+00$ \\
\hline$A m-241$ & $6.387 \mathrm{E}+08$ & 168 & BEA-GATE & $2.212 \mathrm{E}-03$ \\
\hline $\mathrm{Am}-241$ & $6.387 \mathrm{E}+08$ & 168 & BEA-REST & $5.428 \mathrm{E}-01$ \\
\hline$A m-241$ & $6.387 \mathrm{E}+08$ & 168 & $B E A-I F$ & $0.000 \mathrm{E}+00$ \\
\hline$A m-241$ & $6.387 E+08$ & 168 & BEA-NRF & $4.502 \mathrm{E}-01$ \\
\hline $\mathrm{Am}-241$ & $6.387 \mathrm{E}+08$ & 168 & BEA-RTC & $7.787 \mathrm{E}-01$ \\
\hline$A m-241$ & $6.387 \mathrm{E}+08$ & 168 & $\mathrm{BEA}-\mathrm{EBR}$ & $8.487 \mathrm{E}-01$ \\
\hline$A m-241$ & $6.387 \mathrm{E}+08$ & 168 & $\mathrm{BEA}-\mathrm{MFC}$ & $6.402 \mathrm{E}-02$ \\
\hline$A m-241$ & $6.387 \mathrm{E}+08$ & 168 & BEA-SUGAR & $0.000 \mathrm{E}+00$ \\
\hline $\mathrm{Am}-241$ & $6.387 \mathrm{E}+08$ & 168 & BEA-INTEC & $9.743 E-01$ \\
\hline$A m-241$ & $6.387 \mathrm{E}+08$ & 168 & $\mathrm{BEA}-\mathrm{CFA}$ & $9.887 \mathrm{E}-01$ \\
\hline $\mathrm{Am}-241$ & $6.387 \mathrm{E}+08$ & 168 & BEA-EFS & $8.807 \mathrm{E}-01$ \\
\hline$A m-241$ & $6.387 E+08$ & 168 & BEA-CRATER & $0.000 \mathrm{E}+00$ \\
\hline$A m-241$ & $6.387 \mathrm{E}+08$ & 168 & ESER-VAN & $8.815 \mathrm{E}-01$ \\
\hline$A m-241$ & $6.387 \mathrm{E}+08$ & 168 & ESER-CRA & $0.000 \mathrm{E}+00$ \\
\hline
\end{tabular}




\begin{tabular}{|c|c|c|c|}
\hline$A m-241$ & $6.387 \mathrm{E}+08$ & 168 & ESER-ARC \\
\hline$A m-241$ & $6.387 \mathrm{E}+08$ & 168 & ESER-SUG \\
\hline$A m-241$ & $6.387 \mathrm{E}+08$ & 168 & ESER-IDA \\
\hline$A m-241$ & $6.387 \mathrm{E}+08$ & 168 & ESER-DUB \\
\hline$A m-241$ & $6.387 \mathrm{E}+08$ & 168 & ESER-MON \\
\hline $\mathrm{Am}-241$ & $6.387 \mathrm{E}+08$ & 168 & ESER-EFS \\
\hline Am-241 & $6.387 \mathrm{E}+08$ & 168 & ESER-ATO \\
\hline$A m-241$ & $6.387 \mathrm{E}+08$ & 168 & ESER-MOU \\
\hline$A m-241$ & $6.387 \mathrm{E}+08$ & 168 & ESER-BLU \\
\hline$A m-241$ & $6.387 \mathrm{E}+08$ & 168 & ESER-TER \\
\hline $\mathrm{Am}-241$ & $6.387 \mathrm{E}+08$ & 168 & ESER-HOW \\
\hline$A m-241$ & $6.387 \mathrm{E}+08$ & 168 & RWMCS \\
\hline$A m-241$ & $6.387 \mathrm{E}+08$ & 168 & $\mathrm{MFCN}$ \\
\hline Am-241 & $6.387 \mathrm{E}+08$ & 168 & MFCGS \\
\hline $\mathrm{Am}-241$ & $6.387 \mathrm{E}+08$ & 168 & Onsite_Station \\
\hline Am-241 & $6.387 \mathrm{E}+08$ & 168 & Offsite Station \\
\hline $\mathrm{Cs}-137$ & $5.567 \mathrm{E}+10$ & 168 & $\mathrm{BEA}-\mathrm{TRA}{ }^{-}$ \\
\hline Cs -137 & $5.567 \mathrm{E}+10$ & 168 & $\mathrm{BEA}-\mathrm{CPP}$ \\
\hline Cs -137 & $5.567 \mathrm{E}+10$ & 168 & BEA-RWMC \\
\hline Cs -137 & $5.567 \mathrm{E}+10$ & 168 & BEA-VAN \\
\hline Cs -137 & $5.567 \mathrm{E}+10$ & 168 & $\mathrm{BEA}-\mathrm{IRC}$ \\
\hline Cs -137 & $5.567 \mathrm{E}+10$ & 168 & BEA-BLKFT \\
\hline $\mathrm{Cs}-137$ & $5.567 \mathrm{E}+10$ & 168 & $\mathrm{BEA}-\mathrm{SMC}$ \\
\hline Cs -137 & $5.567 \mathrm{E}+10$ & 168 & BEA-GATE \\
\hline Cs -137 & $5.567 \mathrm{E}+10$ & 168 & BEA-REST \\
\hline $\mathrm{Cs}-137$ & $5.567 \mathrm{E}+10$ & 168 & $\mathrm{BEA}-\mathrm{IF}$ \\
\hline $\mathrm{Cs}-137$ & $5.567 \mathrm{E}+10$ & 168 & $\mathrm{BEA}-\mathrm{NRF}$ \\
\hline Cs -137 & $5.567 \mathrm{E}+10$ & 168 & BEA-RTC \\
\hline Cs -137 & $5.567 \mathrm{E}+10$ & 168 & $\mathrm{BEA}-\mathrm{EBR}$ \\
\hline $\mathrm{Cs}-137$ & $5.567 \mathrm{E}+10$ & 168 & BEA-MFC \\
\hline Cs -137 & $5.567 \mathrm{E}+10$ & 168 & BEA-SUGAR \\
\hline Cs -137 & $5.567 \mathrm{E}+10$ & 168 & BEA-INTEC \\
\hline Cs -137 & $5.567 \mathrm{E}+10$ & 168 & $\mathrm{BEA}-\mathrm{CFA}$ \\
\hline $\mathrm{Cs}-137$ & $5.567 \mathrm{E}+10$ & 168 & $\mathrm{BEA}-\mathrm{EFS}$ \\
\hline Cs -137 & $5.567 \mathrm{E}+10$ & 168 & BEA-CRATER \\
\hline Cs -137 & $5.567 \mathrm{E}+10$ & 168 & ESER-VAN \\
\hline Cs -137 & $5.567 \mathrm{E}+10$ & 168 & ESER-CRA \\
\hline $\mathrm{Cs}-137$ & $5.567 \mathrm{E}+10$ & 168 & ESER-ARC \\
\hline $\mathrm{Cs}-137$ & $5.567 \mathrm{E}+10$ & 168 & ESER-SUG \\
\hline $\mathrm{Cs}-137$ & $5.567 \mathrm{E}+10$ & 168 & ESER-IDA \\
\hline Cs -137 & $5.567 \mathrm{E}+10$ & 168 & ESER-DUB \\
\hline Cs -137 & $5.567 \mathrm{E}+10$ & 168 & ESER-MON \\
\hline $\mathrm{Cs}-137$ & $5.567 \mathrm{E}+10$ & 168 & ESER-EFS \\
\hline Cs -137 & $5.567 \mathrm{E}+10$ & 168 & ESER-ATO \\
\hline $\mathrm{Cs}-137$ & $5.567 \mathrm{E}+10$ & 168 & ESER-MOU \\
\hline Cs -137 & $5.567 \mathrm{E}+10$ & 168 & ESER-BLU \\
\hline $\mathrm{Cs}-137$ & $5.567 \mathrm{E}+10$ & 168 & ESER-TER \\
\hline $\mathrm{Cs}-137$ & $5.567 \mathrm{E}+10$ & 168 & ESER-HOW \\
\hline Cs -137 & $5.567 \mathrm{E}+10$ & 168 & RWMCS \\
\hline Cs -137 & $5.567 \mathrm{E}+10$ & 168 & MFCN \\
\hline Cs -137 & $5.567 \mathrm{E}+10$ & 168 & MFCGS \\
\hline $\mathrm{Cs}-137$ & $5.567 \mathrm{E}+10$ & 168 & Onsite_Station \\
\hline $\mathrm{Cs}-137$ & $5.567 \mathrm{E}+10$ & 168 & offsitē_Station \\
\hline Pu-238 & $5.686 \mathrm{E}+08$ & 168 & BEA-TRA \\
\hline Pu-238 & $5.686 \mathrm{E}+08$ & 168 & $\mathrm{BEA}-\mathrm{CPP}$ \\
\hline Pu-238 & $5.686 \mathrm{E}+08$ & 168 & BEA-RWMC \\
\hline $\mathrm{Pu}-238$ & $5.686 \mathrm{E}+08$ & 168 & $\mathrm{BEA}-\mathrm{VAN}$ \\
\hline Pu-238 & $5.686 \mathrm{E}+08$ & 168 & $\mathrm{BEA}-\mathrm{IRC}$ \\
\hline Pu-238 & $5.686 \mathrm{E}+08$ & 168 & BEA-BLKFT \\
\hline $\mathrm{Pu}-238$ & $5.686 \mathrm{E}+08$ & 168 & BEA-SMC \\
\hline $\mathrm{Pu}-238$ & $5.686 \mathrm{E}+08$ & 168 & BEA-GATE \\
\hline Pu-238 & $5.686 \mathrm{E}+08$ & 168 & BEA-REST \\
\hline Pu-238 & $5.686 \mathrm{E}+08$ & 168 & $\mathrm{BEA}-\mathrm{IF}$ \\
\hline Pu-238 & $5.686 \mathrm{E}+08$ & 168 & $\mathrm{BEA}-\mathrm{NRF}$ \\
\hline Pu-238 & $5.686 \mathrm{E}+08$ & 168 & $\mathrm{BEA}-\mathrm{RTC}$ \\
\hline Pu-238 & $5.686 \mathrm{E}+08$ & 168 & $\mathrm{BEA}-\mathrm{EBR}$ \\
\hline $\mathrm{Pu}-238$ & $5.686 \mathrm{E}+08$ & 168 & $\mathrm{BEA}-\mathrm{MFC}$ \\
\hline $\mathrm{Pu}-238$ & $5.686 \mathrm{E}+08$ & 168 & BEA-SUGAR \\
\hline Pu-238 & $5.686 \mathrm{E}+08$ & 168 & BEA-INTEC \\
\hline $\mathrm{Pu}-238$ & $5.686 \mathrm{E}+08$ & 168 & $\mathrm{BEA}-\mathrm{CFA}$ \\
\hline Pu-238 & $5.686 \mathrm{E}+08$ & 168 & $\mathrm{BEA}-\mathrm{EFS}$ \\
\hline Pu-238 & $5.686 \mathrm{E}+08$ & 168 & BEA-CRATER \\
\hline Pu-238 & $5.686 \mathrm{E}+08$ & 168 & ESER-VAN \\
\hline $\mathrm{Pu}-238$ & $5.686 \mathrm{E}+08$ & 168 & ESER-CRA \\
\hline Pu-238 & $5.686 \mathrm{E}+08$ & 168 & ESER-ARC \\
\hline Pu-238 & $5.686 \mathrm{E}+08$ & 168 & ESER-SUG \\
\hline $\mathrm{Pu}-238$ & $5.686 \mathrm{E}+08$ & 168 & ESER-IDA \\
\hline Pu-238 & $5.686 \mathrm{E}+08$ & 168 & ESER-DUB \\
\hline Pu-238 & $5.686 \mathrm{E}+08$ & 168 & ESER-MON \\
\hline $\mathrm{Pu}-238$ & $5.686 \mathrm{E}+08$ & 168 & ESER-EFS \\
\hline Pu-238 & $5.686 \mathrm{E}+08$ & 168 & ESER-ATO \\
\hline Pu-238 & $5.686 \mathrm{E}+08$ & 168 & ESER-MOU \\
\hline $\mathrm{Pu}-238$ & $5.686 \mathrm{E}+08$ & 168 & ESER-BLU \\
\hline Pu-238 & $5.686 \mathrm{E}+08$ & 168 & ESER-TER \\
\hline Pu-238 & $5.686 \mathrm{E}+08$ & 168 & ESER-HOW \\
\hline Pu-238 & $5.686 \mathrm{E}+08$ & 168 & RWMCS \\
\hline $\mathrm{Pu}-238$ & $5.686 \mathrm{E}+08$ & 168 & $\mathrm{MFCN}$ \\
\hline $\mathrm{Pu}-238$ & $5.686 \mathrm{E}+08$ & 168 & MFCGS \\
\hline Pu-238 & $5.686 \mathrm{E}+08$ & 168 & Onsite_Station \\
\hline Pu-238 & $5.686 \mathrm{E}+08$ & 168 & Offsitē_Station \\
\hline Pu-239 & $5.169 \mathrm{E}+08$ & 168 & BEA-TRA \\
\hline Pu-239 & $5.169 \mathrm{E}+08$ & 168 & $\mathrm{BEA}-\mathrm{CPP}$ \\
\hline $\mathrm{Pu}-239$ & $5.169 \mathrm{E}+08$ & 168 & BEA-RWMC \\
\hline $\mathrm{Pu}-239$ & $5.169 \mathrm{E}+08$ & 168 & BEA-VAN \\
\hline Pu-239 & $5.169 \mathrm{E}+08$ & 168 & $\mathrm{BEA}-\mathrm{IRC}$ \\
\hline
\end{tabular}




\begin{tabular}{|c|c|c|c|}
\hline Pu-239 & $5.169 \mathrm{E}+08$ & 168 & BEA-BLKFT \\
\hline Pu-239 & $5.169 \mathrm{E}+08$ & 168 & $\mathrm{BEA}-\mathrm{SMC}$ \\
\hline Pu-239 & $5.169 \mathrm{E}+08$ & 168 & BEA-GATE \\
\hline Pu-239 & $5.169 \mathrm{E}+08$ & 168 & BEA-REST \\
\hline Pu-239 & $5.169 \mathrm{E}+08$ & 168 & $\mathrm{BEA}-\mathrm{IF}$ \\
\hline $\mathrm{Pu}-239$ & $5.169 \mathrm{E}+08$ & 168 & $\mathrm{BEA}-\mathrm{NRF}$ \\
\hline $\mathrm{Pu}-239$ & $5.169 \mathrm{E}+08$ & 168 & $\mathrm{BEA}-\mathrm{RTC}$ \\
\hline Pu-239 & $5.169 \mathrm{E}+08$ & 168 & $B E A-E B R$ \\
\hline Pu-239 & $5.169 \mathrm{E}+08$ & 168 & BEA-MFC \\
\hline Pu-239 & $5.169 \mathrm{E}+08$ & 168 & BEA-SUGAR \\
\hline Pu-239 & $5.169 \mathrm{E}+08$ & 168 & BEA-INTEC \\
\hline Pu-239 & $5.169 \mathrm{E}+08$ & 168 & $\mathrm{BEA}-\mathrm{CFA}$ \\
\hline Pu-239 & $5.169 \mathrm{E}+08$ & 168 & BEA-EFS \\
\hline Pu-239 & $5.169 \mathrm{E}+08$ & 168 & BEA-CRATER \\
\hline Pu-239 & $5.169 \mathrm{E}+08$ & 168 & ESER-VAN \\
\hline $\mathrm{Pu}-239$ & $5.169 \mathrm{E}+08$ & 168 & ESER-CRA \\
\hline Pu-239 & $5.169 \mathrm{E}+08$ & 168 & ESER-ARC \\
\hline Pu-239 & $5.169 \mathrm{E}+08$ & 168 & ESER-SUG \\
\hline Pu-239 & $5.169 \mathrm{E}+08$ & 168 & ESER-IDA \\
\hline Pu-239 & $5.169 \mathrm{E}+08$ & 168 & ESER-DUB \\
\hline $\mathrm{Pu}-239$ & $5.169 \mathrm{E}+08$ & 168 & ESER-MON \\
\hline Pu-239 & $5.169 \mathrm{E}+08$ & 168 & ESER-EFS \\
\hline $\mathrm{Pu}-239$ & $5.169 \mathrm{E}+08$ & 168 & ESER-ATO \\
\hline $\mathrm{Pu}-239$ & $5.169 \mathrm{E}+08$ & 168 & ESER-MOU \\
\hline $\mathrm{Pu}-239$ & $5.169 \mathrm{E}+08$ & 168 & ESER-BLU \\
\hline Pu-239 & $5.169 \mathrm{E}+08$ & 168 & ESER-TER \\
\hline $\mathrm{Pu}-239$ & $5.169 \mathrm{E}+08$ & 168 & ESER-HOW \\
\hline $\mathrm{Pu}-239$ & $5.169 \mathrm{E}+08$ & 168 & RWMCS \\
\hline Pu-239 & $5.169 \mathrm{E}+08$ & 168 & $\mathrm{MFCN}$ \\
\hline Pu-239 & $5.169 \mathrm{E}+08$ & 168 & MFCGS \\
\hline Pu-239 & $5.169 \mathrm{E}+08$ & 168 & Onsite station \\
\hline Pu-239 & $5.169 \mathrm{E}+08$ & 168 & Offsite Station \\
\hline Sr -90 & $2.132 \mathrm{E}+10$ & 168 & $\mathrm{BEA}-\mathrm{TRA}$ \\
\hline $\mathrm{Sr}-90$ & $2.132 \mathrm{E}+10$ & 168 & BEA-CPP \\
\hline $\mathrm{Sr}-90$ & $2.132 \mathrm{E}+10$ & 168 & BEA-RWMC \\
\hline $\mathrm{Sr}-90$ & $2.132 \mathrm{E}+10$ & 168 & BEA-VAN \\
\hline $\mathrm{Sr}-90$ & $2.132 \mathrm{E}+10$ & 168 & BEA-IRC \\
\hline $\mathrm{Sr}-90$ & $2.132 \mathrm{E}+10$ & 168 & BEA-BLKFT \\
\hline $\mathrm{Sr}-90$ & $2.132 \mathrm{E}+10$ & 168 & BEA-SMC \\
\hline $\mathrm{Sr}-90$ & $2.132 \mathrm{E}+10$ & 168 & $\mathrm{BEA}-\mathrm{GATE}$ \\
\hline $\mathrm{Sr}-90$ & $2.132 \mathrm{E}+10$ & 168 & BEA-REST \\
\hline $\mathrm{Sr}-90$ & $2.132 \mathrm{E}+10$ & 168 & $\mathrm{BEA}-\mathrm{IF}$ \\
\hline $\mathrm{Sr}-90$ & $2.132 \mathrm{E}+10$ & 168 & BEA-NRF \\
\hline $\mathrm{Sr}-90$ & $2.132 \mathrm{E}+10$ & 168 & BEA-RTC \\
\hline $\mathrm{Sr}-90$ & $2.132 \mathrm{E}+10$ & 168 & $\mathrm{BEA}-\mathrm{EBR}$ \\
\hline $\mathrm{Sr}-90$ & $2.132 \mathrm{E}+10$ & 168 & BEA-MFC \\
\hline $\mathrm{Sr}-90$ & $2.132 \mathrm{E}+10$ & 168 & BEA-SUGAR \\
\hline $\mathrm{Sr}-90$ & $2.132 \mathrm{E}+10$ & 168 & BEA-INTEC \\
\hline $\mathrm{Sr}-90$ & $2.132 \mathrm{E}+10$ & 168 & BEA-CFA \\
\hline $\mathrm{Sr}-90$ & $2.132 \mathrm{E}+10$ & 168 & BEA-EFS \\
\hline $\mathrm{Sr}-90$ & $2.132 \mathrm{E}+10$ & 168 & BEA-CRATER \\
\hline $\mathrm{Sr}-90$ & $2.132 \mathrm{E}+10$ & 168 & ESER-VAN \\
\hline $\mathrm{Sr}-90$ & $2.132 \mathrm{E}+10$ & 168 & ESER-CRA \\
\hline $\mathrm{Sr}-90$ & $2.132 \mathrm{E}+10$ & 168 & ESER-ARC \\
\hline $\mathrm{Sr}-90$ & $2.132 \mathrm{E}+10$ & 168 & ESER-SUG \\
\hline $\mathrm{Sr}-90$ & $2.132 \mathrm{E}+10$ & 168 & ESER-IDA \\
\hline $\mathrm{Sr}-90$ & $2.132 \mathrm{E}+10$ & 168 & ESER-DUB \\
\hline $\mathrm{Sr}-90$ & $2.132 \mathrm{E}+10$ & 168 & ESER-MON \\
\hline $\mathrm{Sr}-90$ & $2.132 \mathrm{E}+10$ & 168 & ESER-EFS \\
\hline $\mathrm{Sr}-90$ & $2.132 \mathrm{E}+10$ & 168 & ESER-ATO \\
\hline $\mathrm{Sr}-90$ & $2.132 \mathrm{E}+10$ & 168 & ESER-MOU \\
\hline $\mathrm{Sr}-90$ & $2.132 \mathrm{E}+10$ & 168 & ESER-BLU \\
\hline $\mathrm{Sr}-90$ & $2.132 \mathrm{E}+10$ & 168 & ESER-TER \\
\hline $\mathrm{Sr}-90$ & $2.132 \mathrm{E}+10$ & 168 & ESER-HOW \\
\hline $\mathrm{Sr}-90$ & $2.132 \mathrm{E}+10$ & 168 & RWMCS \\
\hline $\mathrm{Sr}-90$ & $2.132 \mathrm{E}+10$ & 168 & $\mathrm{MFCN}$ \\
\hline $\mathrm{Sr}-90$ & $2.132 \mathrm{E}+10$ & 168 & MFCGS \\
\hline $\mathrm{Sr}-90$ & $2.132 \mathrm{E}+10$ & 168 & Onsite Station \\
\hline $\mathrm{Sr}-90$ & $2.132 \mathrm{E}+10$ & 168 & Offsite Station \\
\hline$I-131$ & $1.422 \mathrm{E}+11$ & 168 & BEA-TRA \\
\hline$I-131$ & $1.422 \mathrm{E}+11$ & 168 & $\mathrm{BEA}-\mathrm{CPP}$ \\
\hline I-131 & $1.422 \mathrm{E}+11$ & 168 & BEA-RWMC \\
\hline$I-131$ & $1.422 \mathrm{E}+11$ & 168 & BEA-VAN \\
\hline$I-131$ & $1.422 \mathrm{E}+11$ & 168 & BEA-IRC \\
\hline I-131 & $1.422 \mathrm{E}+11$ & 168 & BEA-BLKFT \\
\hline$I-131$ & $1.422 \mathrm{E}+11$ & 168 & BEA-SMC \\
\hline I-131 & $1.422 \mathrm{E}+11$ & 168 & BEA-GATE \\
\hline$I-131$ & $1.422 \mathrm{E}+11$ & 168 & BEA-REST \\
\hline$I-131$ & $1.422 \mathrm{E}+11$ & 168 & $\mathrm{BEA}-\mathrm{IF}$ \\
\hline I-131 & $1.422 \mathrm{E}+11$ & 168 & $\mathrm{BEA}-\mathrm{NRF}$ \\
\hline I-131 & $1.422 \mathrm{E}+11$ & 168 & BEA-RTC \\
\hline$I-131$ & $1.422 \mathrm{E}+11$ & 168 & $\mathrm{BEA}-\mathrm{EBR}$ \\
\hline$I-131$ & $1.422 \mathrm{E}+11$ & 168 & BEA-MFC \\
\hline$I-131$ & $1.422 \mathrm{E}+11$ & 168 & BEA-SUGAR \\
\hline I-131 & $1.422 \mathrm{E}+11$ & 168 & BEA-INTEC \\
\hline I-131 & $1.422 \mathrm{E}+11$ & 168 & $\mathrm{BEA}-\mathrm{CFA}$ \\
\hline$I-131$ & $1.422 \mathrm{E}+11$ & 168 & BEA-EFS \\
\hline I-131 & $1.422 \mathrm{E}+11$ & 168 & BEA-CRATER \\
\hline$I-131$ & $1.422 \mathrm{E}+11$ & 168 & ESER-VAN \\
\hline$I-131$ & $1.422 \mathrm{E}+11$ & 168 & ESER-CRA \\
\hline$I-131$ & $1.422 \mathrm{E}+11$ & 168 & ESER-ARC \\
\hline$I-131$ & $1.422 \mathrm{E}+11$ & 168 & ESER-SUG \\
\hline$I-131$ & $1.422 \mathrm{E}+11$ & 168 & ESER-IDA \\
\hline $\mathrm{I}-131$ & $1.422 \mathrm{E}+11$ & 168 & ESER-DUB \\
\hline$I-131$ & $1.422 \mathrm{E}+11$ & 168 & ESER-MON \\
\hline
\end{tabular}




\begin{tabular}{|c|c|c|c|c|c|}
\hline I-131 & $1.422 \mathrm{E}+11$ & 168 & ESER-EFS & $1.000 \mathrm{E}+00$ & \\
\hline $\mathrm{I}-131$ & $1.422 \mathrm{E}+11$ & 168 & ESER-ATO & $9.907 \mathrm{E}-01$ & \\
\hline I-131 & $1.422 \mathrm{E}+11$ & 168 & ESER-MOU & $2.877 \mathrm{E}-01$ & \\
\hline I-131 & $1.422 \mathrm{E}+11$ & 168 & ESER-BLU & $2.758 \mathrm{E}-01$ & \\
\hline$I-131$ & $1.422 \mathrm{E}+11$ & 168 & ESER-TER & $8.851 \mathrm{E}-01$ & \\
\hline I-131 & $1.422 \mathrm{E}+11$ & 168 & ESER-HOW & $7.419 \mathrm{E}-01$ & \\
\hline I-131 & $1.422 \mathrm{E}+11$ & 168 & RWMCS & $9.951 \mathrm{E}-01$ & \\
\hline I-131 & $1.422 \mathrm{E}+11$ & 168 & $\mathrm{MFCN}$ & $9.593 \mathrm{E}-01$ & \\
\hline I-131 & $1.422 \mathrm{E}+11$ & 168 & MFCGS & $9.486 \mathrm{E}-01$ & \\
\hline$I-131$ & $1.422 \mathrm{E}+11$ & 168 & Onsite_station & $1.000 \mathrm{E}+00$ & $6.945 \mathrm{E}-01$ \\
\hline I-131 & $1.422 \mathrm{E}+11$ & 168 & Offsitē_station & $0.000 \mathrm{E}+00$ & $0.000 \mathrm{E}+00$ \\
\hline
\end{tabular}

RESIDENT SCENARIO, EXISTING NETWORK, OPTIMIZED FOR CITRIC

* This output was produced by the model:

FREQD

FREQuency of Detection program for INL sources * and air monitoring network. version date (yyyymmdd) 20141120

Arthur S. Rood

K-Spar Inc. $4835 \mathrm{~W}$ Foxtrail Lane

Idaho Falls, ID 83402

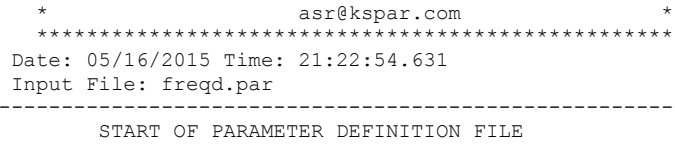

asrekspar.com

te: 05/16/2015 Time: $21: 22: 54.631$

Input File: freqd.par

START OF PARAMETER DEFINITION FILE

FreqD.f95 - Evaluation of existing network for 168-hr release yielding 1 mrem/yr Data File:../././TICSALL/CITRC_combine.tx $\begin{array}{lll}\mathrm{BEA}-\mathrm{CPP} & 3.398 \quad 168\end{array}$ BEA-RWMC $3.398 \quad 168$ BEA-VAN $3.398 \quad 168$ BEA-IRC $\quad 3.398 \quad 168$ BEA-BLKFT $3.398 \quad 168$ BEA-SMC $\quad 3.398 \quad 168$ $\begin{array}{lll}B E A-G A T E & 3.398 \quad 168\end{array}$ $\begin{array}{lll}\text { BEA-ARA } & 3.398 \quad 168\end{array}$ BEA-REST $\quad 3.398 \quad 168$ BEA-IF $\quad 3.398 \quad 168$ BEA-NRF $\quad 3.398 \quad 168$ $\begin{array}{lll}\text { BEA-RTC } & 3.398 & 168\end{array}$ BEA-EBR $\quad 3.398 \quad 168$ BEA-MFC $\quad 3.398 \quad 168$ BEA-SUGAR $3.398 \quad 168$ $\begin{array}{lll}\mathrm{BEA}-\mathrm{PBF} & 3.398 \quad 168\end{array}$ BEA-INTEC $\quad 3.398 \quad 168$

$\begin{array}{lll}B E A-C F A & 3.398 & 168\end{array}$ BEA-EFS $\quad 3.398 \quad 168$ BEA-CRATER $\quad 3.398 \quad 168$ $\begin{array}{lll}\text { ESER-VAN } & 3.398 \quad 168\end{array}$ $\begin{array}{lll}\text { ESER-CRA } & 3.398 & 168\end{array}$ $\begin{array}{lll}\text { ESER-ARC } & 3.398 & 168\end{array}$ ESER-SUG $\quad 3.398 \quad 168$ ESER-IDA $3.398 \quad 168$ ESER-DUB $\quad 3.398 \quad 168$ $\begin{array}{lll}\text { ESER-MON } & 3.398 \quad 168\end{array}$ ESER-FAA $\quad 3.398 \quad 168$ $\begin{array}{lll}\text { ESER-MAI } & 3.398 & 168\end{array}$ $\begin{array}{lll}\text { ESER-MAI } & 3.398 & 168 \\ \text { ESER-EFS } & 3.398 & 168\end{array}$ $\begin{array}{lll}\text { ESER-EFS } & 3.398 & 168 \\ \text { ESER-ATO } & 3.398 & 168\end{array}$ $\begin{array}{lll}\text { ESER-ATO } & 3.398 & 168 \\ \text { ESER-MOU } & 3.398 & 168\end{array}$ $\begin{array}{lll}\text { ESER-MOU } & 3.398 & 168 \\ \text { ESER-BLU } & 3.398 & 168\end{array}$ $\begin{array}{lll}\text { ESER-BLU } & 3.398 & 168 \\ & 3.398 & 168\end{array}$ $\begin{array}{lll}\text { ESER-TER } & 3.398 & 168 \\ \text { ESER-HOW } & 3.398 & 168\end{array}$ $\begin{array}{lll}\text { MEI01 } & 3.398 \quad 168\end{array}$ $\begin{array}{lll}\text { MEIO2 } & 3.398 \quad 168\end{array}$ MEI03 $3.398 \quad 168$ sampname, flowr, rtime, onsite, incsamp sampname, flowr, rtime, onsite, incsamp sampname, flowr, rtime, onsite, incsamp sampname, flowr, rtime, onsite, incsamp sampname, flowr, rtime, onsite, incsamp sampname, flowr, rtime, onsite, incsamp sampname, flowr, rtime, onsite, incsamp sampname, flowr, rtime, onsite, incsamp sampname, flowr, rtime, onsite, incsamp sampname, flowr, rtime, onsite, incsamp sampname, flowr, rtime, onsite, incsamp sampname, flowr, rtime, onsite, incsamp samprame, flowr, rtime, onsite, incsamp sampname, flowr, rtime, onsite, incsamp sampname, flowr, rtime, onsite, incsamp sampname, flowr, rtime, onsite, incsamp sampname, flowr, rtime, onsite, incsamp sampname, flowr, rtime, onsite, incsamp sampname, flowr, rtime, onsite, incsamp sampname, flowr, rtime, onsite, incsamp sampname, flowr, rtime, onsite, incsamp sampname, flowr, rtime, onsite, incsamp sampname, flowr, rtime, onsite, incsamp sampname, flowr, rtime, onsite, incsamp sampname, flowr, rtime, onsite, lncsamp sanphane, flowr, rtime, onsite, incsanp sampname, flowr, rtime, onsite, incsamp sampname, flowr, rtime, onsite, incsamp sampname, flowr, rtime, onsite, incsamp sampname, flowr, rtime, onsite, incsamp sampname, flowr, rtime, onsite, incsamp sampname, flowr, rtime, onsite, incsamp sampname, flowr, rtime, onsite, incsamp sampname, flowr, rtime, onsite, incsamp sampname, flowr, rtime, onsite, incsamp sampname, flowr, rtime, onsite, incsamp sampname, flowr, rtime, onsite, incsamp sampname, flowr, rtime, onsite, incsamp sampname, flowr, rtime, onsite, incsamp sampname, flowr, rtime, onsite, incsamp sampname, flowr, rtime, onsite, incsamp sampname, flowr, rtime, onsite, incsamp sampname, flowr, rtime, onsite, incsamp sampname, flowr, rtime, onsite, incsamp sampname, flowr, rtime, onsite, incsamp sampname, flowr, rtime, onsite, incsamp sampname, flowr, rtime, onsite, incsamp sampname, flowr, rtime, onsite, incsamp sampname, flowr, rtime, onsite, incsamp sampnam, flowr, rtime, onsite, incsamp sampame, flowr, rtime, onsite, incsamp sampname, flowr, rtime, onsite, incsamp sampname, flowr, rtime, onsite, incsamp sampname, flowr, rtime, onsite, incsamp sampname, flowr, rtime, onsite, incsamp sampname, flowr, rtime, onsite, incsamp sampname, flowr, rtime, onsite, incsamp sampname, flowr, rtime, onsite, incsamp sampname, flowr, rtime, onsite, incsamp 


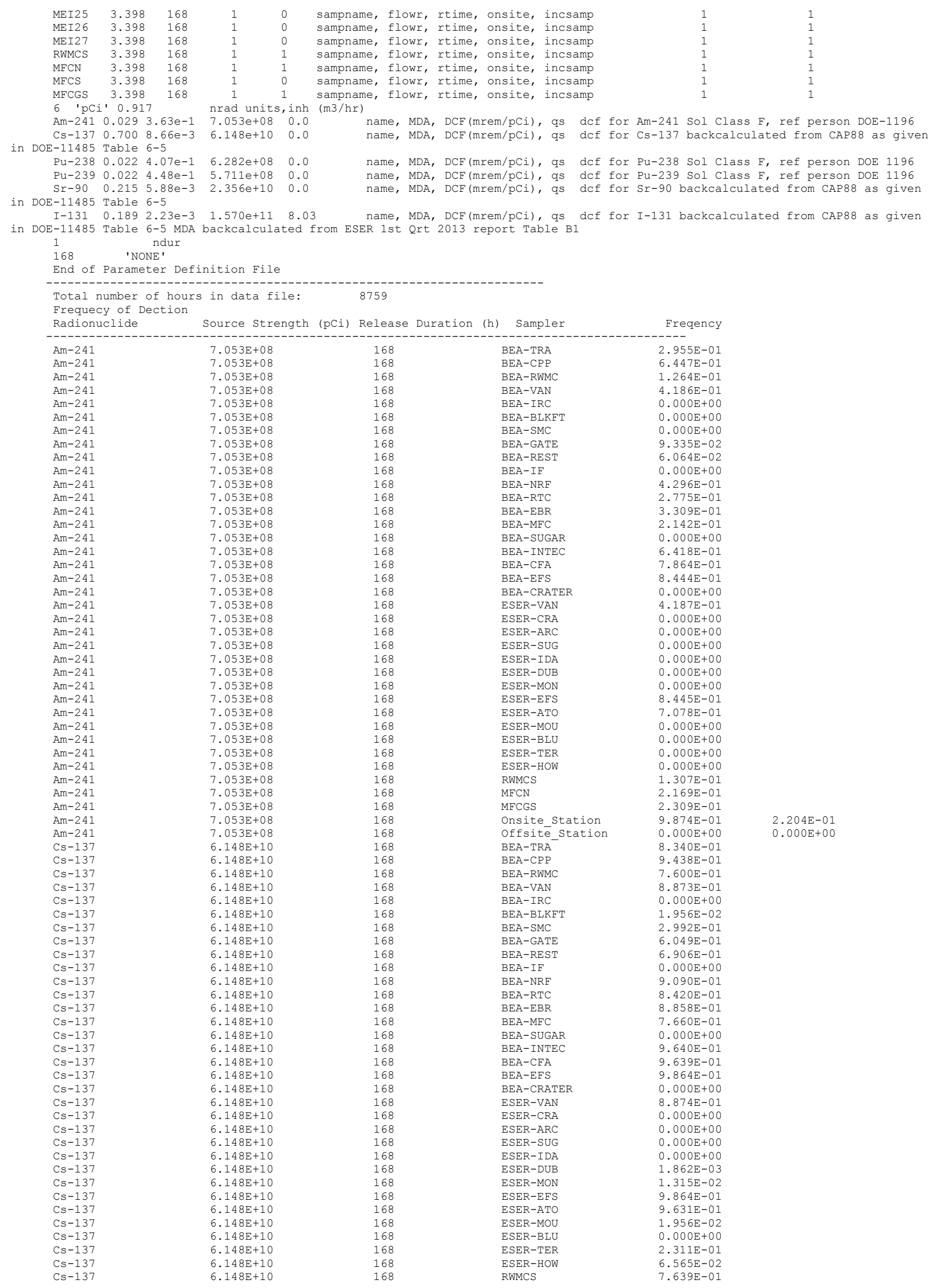




\begin{tabular}{|c|c|c|c|}
\hline Cs -137 & $6.148 \mathrm{E}+10$ & 168 & $\mathrm{MFCN}$ \\
\hline $\mathrm{Cs}-137$ & $6.148 \mathrm{E}+10$ & 168 & MFCGS \\
\hline Cs -137 & $6.148 \mathrm{E}+10$ & 168 & Onsite_Station \\
\hline Cs -137 & $6.148 \mathrm{E}+10$ & 168 & Offsité_Station \\
\hline $\mathrm{Pu}-238$ & $6.282 \mathrm{E}+08$ & 168 & BEA-TRA \\
\hline $\mathrm{Pu}-238$ & $6.282 \mathrm{E}+08$ & 168 & $\mathrm{BEA}-\mathrm{CPP}$ \\
\hline Pu-238 & $6.282 \mathrm{E}+08$ & 168 & BEA-RWMC \\
\hline Pu-238 & $6.282 \mathrm{E}+08$ & 168 & BEA-VAN \\
\hline $\mathrm{Pu}-238$ & $6.282 \mathrm{E}+08$ & 168 & BEA-IRC \\
\hline $\mathrm{Pu}-238$ & $6.282 \mathrm{E}+08$ & 168 & BEA-BLKFT \\
\hline Pu-238 & $6.282 \mathrm{E}+08$ & 168 & BEA-SMC \\
\hline Pu-238 & $6.282 \mathrm{E}+08$ & 168 & BEA-GATE \\
\hline Pu-238 & $6.282 \mathrm{E}+08$ & 168 & BEA-REST \\
\hline $\mathrm{Pu}-238$ & $6.282 \mathrm{E}+08$ & 168 & $\mathrm{BEA}-\mathrm{IF}$ \\
\hline Pu-238 & $6.282 \mathrm{E}+08$ & 168 & $\mathrm{BEA}-\mathrm{NRF}$ \\
\hline $\mathrm{Pu}-238$ & $6.282 \mathrm{E}+08$ & 168 & $\mathrm{BEA}-\mathrm{RTC}$ \\
\hline Pu-238 & $6.282 \mathrm{E}+08$ & 168 & BEA-EBR \\
\hline Pu-238 & $6.282 \mathrm{E}+08$ & 168 & BEA-MFC \\
\hline Pu -238 & $6.282 \mathrm{E}+08$ & 168 & BEA-SUGAR \\
\hline $\mathrm{Pu}-238$ & $6.282 \mathrm{E}+08$ & 168 & BEA-INTEC \\
\hline $\mathrm{Pu}-238$ & $6.282 \mathrm{E}+08$ & 168 & $\mathrm{BEA}-\mathrm{CFA}$ \\
\hline $\mathrm{Pu}-238$ & $6.282 \mathrm{E}+08$ & 168 & BEA-EFS \\
\hline $\mathrm{Pu}-238$ & $6.282 \mathrm{E}+08$ & 168 & BEA-CRATER \\
\hline Pu-238 & $6.282 \mathrm{E}+08$ & 168 & ESER-VAN \\
\hline $\mathrm{Pu}-238$ & $6.282 \mathrm{E}+08$ & 168 & ESER-CRA \\
\hline Pu-238 & $6.282 \mathrm{E}+08$ & 168 & ESER-ARC \\
\hline $\mathrm{Pu}-238$ & $6.282 \mathrm{E}+08$ & 168 & ESER-SUG \\
\hline Pu-238 & $6.282 \mathrm{E}+08$ & 168 & ESER-IDA \\
\hline Pu-238 & $6.282 \mathrm{E}+08$ & 168 & ESER-DUB \\
\hline Pu-238 & $6.282 \mathrm{E}+08$ & 168 & ESER-MON \\
\hline Pu-238 & $6.282 \mathrm{E}+08$ & 168 & ESER-EFS \\
\hline Pu-238 & $6.282 \mathrm{E}+08$ & 168 & ESER-ATO \\
\hline Pu-238 & $6.282 \mathrm{E}+08$ & 168 & ESER-MOU \\
\hline $\mathrm{Pu}-238$ & $6.282 \mathrm{E}+08$ & 168 & ESER-BLU \\
\hline Pu-238 & $6.282 \mathrm{E}+08$ & 168 & ESER-TER \\
\hline $\mathrm{Pu}-238$ & $6.282 \mathrm{E}+08$ & 168 & ESER-HOW \\
\hline $\mathrm{Pu}-238$ & $6.282 \mathrm{E}+08$ & 168 & RWMCS \\
\hline $\mathrm{Pu}-238$ & $6.282 \mathrm{E}+08$ & 168 & MFCN \\
\hline Pu-238 & $6.282 \mathrm{E}+08$ & 168 & MFCGS \\
\hline $\mathrm{Pu}-238$ & $6.282 \mathrm{E}+08$ & 168 & Onsite Station \\
\hline $\mathrm{Pu}-238$ & $6.282 \mathrm{E}+08$ & 168 & Offsite Station \\
\hline Pu-239 & $5.711 \mathrm{E}+08$ & 168 & $\mathrm{BEA}-\mathrm{TRA}$ \\
\hline Pu-239 & $5.711 \mathrm{E}+08$ & 168 & $\mathrm{BEA}-\mathrm{CPP}$ \\
\hline Pu-239 & $5.711 \mathrm{E}+08$ & 168 & BEA-RWMC \\
\hline $\mathrm{Pu}-239$ & $5.711 \mathrm{E}+08$ & 168 & BEA-VAN \\
\hline $\mathrm{Pu}-239$ & $5.711 \mathrm{E}+08$ & 168 & BEA-IRC \\
\hline $\mathrm{Pu}-239$ & $5.711 \mathrm{E}+08$ & 168 & BEA-BLKFT \\
\hline $\mathrm{Pu}-239$ & $5.711 \mathrm{E}+08$ & 168 & $\mathrm{BEA}-\mathrm{SMC}$ \\
\hline Pu-239 & $5.711 \mathrm{E}+08$ & 168 & BEA-GATE \\
\hline Pu-239 & $5.711 \mathrm{E}+08$ & 168 & BEA-REST \\
\hline Pu-239 & $5.711 \mathrm{E}+08$ & 168 & $\mathrm{BEA}-\mathrm{IF}$ \\
\hline $\mathrm{Pu}-239$ & $5.711 \mathrm{E}+08$ & 168 & $\mathrm{BEA}-\mathrm{NRF}$ \\
\hline Pu-239 & $5.711 \mathrm{E}+08$ & 168 & BEA-RTC \\
\hline Pu-239 & $5.711 \mathrm{E}+08$ & 168 & $\mathrm{BEA}-\mathrm{EBR}$ \\
\hline $\mathrm{Pu}-239$ & $5.711 \mathrm{E}+08$ & 168 & $\mathrm{BEA}-\mathrm{MFC}$ \\
\hline $\mathrm{Pu}-239$ & $5.711 \mathrm{E}+08$ & 168 & BEA-SUGAR \\
\hline Pu-239 & $5.711 \mathrm{E}+08$ & 168 & BEA-INTEC \\
\hline $\mathrm{Pu}-239$ & $5.711 \mathrm{E}+08$ & 168 & $\mathrm{BEA}-\mathrm{CFA}$ \\
\hline $\mathrm{Pu}-239$ & $5.711 \mathrm{E}+08$ & 168 & $\mathrm{BEA}-\mathrm{EFS}$ \\
\hline Pu-239 & $5.711 \mathrm{E}+08$ & 168 & BEA-CRATER \\
\hline $\mathrm{Pu}-239$ & $5.711 \mathrm{E}+08$ & 168 & ESER-VAN \\
\hline Pu-239 & $5.711 \mathrm{E}+08$ & 168 & ESER-CRA \\
\hline Pu-239 & $5.711 \mathrm{E}+08$ & 168 & ESER-ARC \\
\hline Pu-239 & $5.711 \mathrm{E}+08$ & 168 & ESER-SUG \\
\hline $\mathrm{Pu}-239$ & $5.711 \mathrm{E}+08$ & 168 & ESER-IDA \\
\hline $\mathrm{Pu}-239$ & $5.711 \mathrm{E}+08$ & 168 & ESER-DUB \\
\hline $\mathrm{Pu}-239$ & $5.711 \mathrm{E}+08$ & 168 & ESER-MON \\
\hline Pu-239 & $5.711 \mathrm{E}+08$ & 168 & ESER-EFS \\
\hline $\mathrm{Pu}-239$ & $5.711 \mathrm{E}+08$ & 168 & ESER-ATO \\
\hline Pu-239 & $5.711 \mathrm{E}+08$ & 168 & ESER-MOU \\
\hline Pu-239 & $5.711 \mathrm{E}+08$ & 168 & ESER-BLU \\
\hline $\mathrm{Pu}-239$ & $5.711 \mathrm{E}+08$ & 168 & ESER-TER \\
\hline Pu-239 & $5.711 \mathrm{E}+08$ & 168 & ESER-HOW \\
\hline Pu-239 & $5.711 \mathrm{E}+08$ & 168 & RWMCS \\
\hline Pu-239 & $5.711 \mathrm{E}+08$ & 168 & $\mathrm{MFCN}$ \\
\hline $\mathrm{Pu}-239$ & $5.711 \mathrm{E}+08$ & 168 & MFCGS \\
\hline Pu-239 & $5.711 \mathrm{E}+08$ & 168 & Onsite Station \\
\hline Pu-239 & $5.711 \mathrm{E}+08$ & 168 & Offsitē Station \\
\hline $\mathrm{Sr}-90$ & $2.356 \mathrm{E}+10$ & 168 & BEA-TRA \\
\hline $\mathrm{Sr}-90$ & $2.356 \mathrm{E}+10$ & 168 & $\mathrm{BEA}-\mathrm{CPP}$ \\
\hline $\mathrm{Sr}-90$ & $2.356 \mathrm{E}+10$ & 168 & BEA-RWMC \\
\hline $\mathrm{Sr}-90$ & $2.356 \mathrm{E}+10$ & 168 & $\mathrm{BEA}-\mathrm{VAN}$ \\
\hline $\mathrm{Sr}-90$ & $2.356 \mathrm{E}+10$ & 168 & BEA-IRC \\
\hline $\mathrm{Sr}-90$ & $2.356 \mathrm{E}+10$ & 168 & BEA-BLKFT \\
\hline $\mathrm{Sr}-90$ & $2.356 \mathrm{E}+10$ & 168 & BEA-SMC \\
\hline $\mathrm{Sr}-90$ & $2.356 \mathrm{E}+10$ & 168 & BEA-GATE \\
\hline $\mathrm{Sr}-90$ & $2.356 \mathrm{E}+10$ & 168 & BEA-REST \\
\hline $\mathrm{Sr}-90$ & $2.356 \mathrm{E}+10$ & 168 & $\mathrm{BEA}-\mathrm{IF}$ \\
\hline $\mathrm{Sr}-90$ & $2.356 \mathrm{E}+10$ & 168 & $\mathrm{BEA}-\mathrm{NRF}$ \\
\hline $\mathrm{Sr}-90$ & $2.356 \mathrm{E}+10$ & 168 & BEA-RTC \\
\hline $\mathrm{Sr}-90$ & $2.356 \mathrm{E}+10$ & 168 & $\mathrm{BEA}-\mathrm{EBR}$ \\
\hline $\mathrm{Sr}-90$ & $2.356 \mathrm{E}+10$ & 168 & BEA-MFC \\
\hline $\mathrm{Sr}-90$ & $2.356 \mathrm{E}+10$ & 168 & BEA-SUGAR \\
\hline $\mathrm{Sr}-90$ & $2.356 \mathrm{E}+10$ & 168 & BEA-INTEC \\
\hline $\mathrm{Sr}-90$ & $2.356 \mathrm{E}+10$ & 168 & $\mathrm{BEA}-\mathrm{CFA}$ \\
\hline
\end{tabular}









$\begin{array}{llcl}\text { BEA-MFC } & 3.398 & 168 & 1 \\ \text { BEA-SUGAR } & 3.398 & 168 & 1 \\ \text { BEA-PBF } & 3.398 & 168 & 1 \\ \text { BEA-INTEC } & 3.398 & 168 & 1 \\ \text { BEA-CFA } & 3.398 & 168 & 1 \\ \text { BEA-EFS } & 3.398 & 168 & 1 \\ \text { BEA-CRATER } & 3.398 & 168 & 1 \\ \text { ESER-VAN } & 3.398 & 168 & 1 \\ \text { ESER-CRA } & 3.398 & 168 & 1 \\ \text { ESER-ARC } & 3.398 & 168 & 1 \\ \text { ESER-SUG } & 3.398 & 168 & 1 \\ \text { ESER-IDA } & 3.398 & 168 & 1 \\ \text { ESER-DUB } & 3.398 & 168 & 1 \\ \text { ESER-MON } & 3.398 & 168 & 1 \\ \text { ESER-FAA } & 3.398 & 168 & 1 \\ \text { ESER-MAI } & 3.398 & 168 & 1 \\ \text { ESER-EFS } & 3.398 & 168 & 1 \\ \text { ESER-ATO } & 3.398 & 168 & 1 \\ \text { ESER-MOU } & 3.398 & 168 & 1 \\ \text { ESER-BLU } & 3.398 & 168 & 1 \\ \text { ESER-TER } & 3.398 & 168 & 1 \\ \text { ESER-HOW } & 3.398 & 168 & 1 \\ \text { MEI01 } & 3.398 & 168 & 1 \\ \text { MEI02 } & 3.398 & 168 & 1 \\ \text { MEI03 } & 3.398 & 168 & 1 \\ \text { MEI04 } & 3.398 & 168 & 1 \\ \text { MEI05 } & 3.398 & 168 & 1 \\ \text { MEI06 } & 3.398 & 168 & 1 \\ \text { MEI07 } & 3.398 & 168 & 1 \\ \text { MEI08 } & 3.398 & 168 & 1 \\ \text { MEI09 } & 3.398 & 168 & 1 \\ \text { MEI10 } & 3.398 & 168 & 1 \\ \text { MEI11 } & 3.398 & 168 & 1 \\ \text { MEI12 } & 3.398 & 168 & 1 \\ \text { MEI13 } & 3.398 & 168 & 1 \\ \text { MEI14 } & 3.398 & 168 & 1 \\ \text { MEI15 } & 3.398 & 168 & 1 \\ \text { MEI16 } & 3.398 & 168 & 1 \\ \text { MEI17 } & 3.398 & 168 & 1 \\ \text { MEI18 } & 3.398 & 168 & 1 \\ \text { MEI19 } & 3.398 & 168 & 1 \\ \text { MEI20 } & 3.398 & 168 & 1 \\ \text { MEI21 } & 3.398 & 168 & 1 \\ \text { MEI22 } & 3.398 & 168 & 1 \\ \text { MEI23 } & 3.398 & 168 & 1 \\ \text { MEI24 } & 3.398 & 168 & 1 \\ \text { MEI25 } & 3.398 & 168 & 1 \\ \text { MEI26 } & 3.398 & 168 & 1 \\ \text { MEI27 } & 3.398 & 168 & 1 \\ \text { RWMCS } & 3.398 & 168 & 1 \\ \text { MFCN } & 3.398 & 168 & 1 \\ \text { MFCS } & 3.398 & 168 & 1 \\ \text { MFCGS } & 3.398 & 168 & 1 \\ \text { E 'PC1 } & 0.917 & & n\end{array}$

1 sampname, flowr, rtime, onsite, incsamp
1 sampname, flowr, rtime, onsite, incsamp
0 sampname, flowr, rtime, onsite, incsamp
1 sampname, flowr, rtime, onsite, incsamp
1 sampname, flowr, rtime, onsite, incsamp
1 sampname, flowr, rtime, onsite, incsamp
1 sampname, flowr, rtime, onsite, incsamp
1 sampname, flowr, rtime, onsite, incsamp
1 sampname, flowr, rtime, onsite, incsamp
1 sampname, flowr, rtime, onsite, incsamp
1 sampname, flowr, rtime, onsite, incsamp
1 sampname, flowr, rtime, onsite, incsamp
1 sampname, flowr, rtime, onsite, incsamp
1 sampname, flowr, rtime, onsite, incsamp
0 sampname, flowr, rtime, onsite, incsamp
0 sampname, flowr, rtime, onsite, incsamp
1 sampname, flowr, rtime, onsite, incsamp
1 sampname, flowr, rtime, onsite, incsamp
1 sampname, flowr, rtime, onsite, incsamp
1 sampname, flowr, rtime, onsite, incsamp
1 sampname, flowr, rtime, onsite, incsamp
1 sampname, flowr, rtime, onsite, incsamp
sampname, flowr, rtime, onsite, incsamp
sampname, flowr, rtime, onsite, incsamp
sampname, flowr, rtime, onsite, incsamp
sampname, flowr, rtime, onsite, incsamp
sampname, flowr, rtime, onsite, incsamp
sampname, flowr, rtime, onsite, incsamp
sampname, flowr, rtime, onsite, incsamp
sampname, flowr, rtime, onsite, incsamp
sampname, flowr, rtime, onsite, incsamp
sampname, flowr, rtime, onsite, incsamp
sampname, flowr, rtime, onsite, incsamp
sampname, flowr, rtime, onsite, incsamp
sampname, flowr, rtime, onsite, incsamp
sampname, flowr, rtime, onsite, incsamp
sampname, flowr, rtime, onsite, incsamp
sampname, flowr, rtime, onsite, incsamp
sampname, flowr, rtime, onsite, incsamp
sampname, flowr, rtime, onsite, incsamp
sampname, flowr, rtime, onsite, incsamp
sampname, flowr, rtime, onsite, incsamp
sampname, flowr, rtime, onsite, incsamp
sampname, flowr, rtime, onsite, incsamp
sampname, flowr, rtime, onsite, incsamp
sampname, flowr, rtime, onsite, incsamp
sampname, flowr, rtime, onsite, incsamp
sampname, flowr, rtime, onsite, incsamp
sampname, flowr, rtime, onsite, incsamp
sampname, flowr, rtime, onsite, incsamp
sampname, flowr, rtime, onsite, incsamp
sampname, flowr, rtime, onsite, incsamp MFCGS $\quad 3.398 \quad 168$ 6 'pCi' 0.917 nrad units, inh (m3/hr

Am-241 $0.0293 .63 \mathrm{e}-1 \quad 9.58 \mathrm{E}+08 \quad 0.0$ name, MDA, DCF (mrem/pCi), qs def for Am-241 Sol Class F, ref person DOE-1196 $\begin{array}{rrr}C s-137 & 0.700 & 8.66 \\ \text { in DOF-11485 }\end{array}$

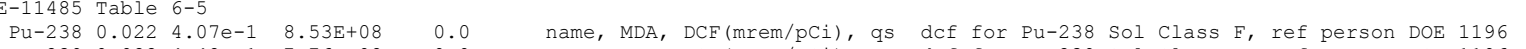
Pu-239 $0.0224 .48 \mathrm{e}-1 \quad 7.76 \mathrm{E}+08$ 0.0 name, MDA, DCF(mrem/pCi), qs def for Pu-239 Sol Class F, ref person DOE 1196 $\mathrm{Sr}-900.2155 .88 \mathrm{e}-3 \quad 3.20 \mathrm{E}+10 \quad 0.0 \quad$ name, MDA, DCF (mrem/pCi), qs def for Sr-90 backcalculated from CAP88 as given in DOE-11485 Table 6-5

I-131 $0.1892 .23 e-3 \quad 2.13 E+11 \quad 8.03$ name, MDA, DCF(mrem/pCi), qs dcf for I-131 backcalculated from CAP88 as given in DOE-11485 Table 6-5 MDA backcalculated from ESER 1st Qrt 2013 report Table B1

168 ndu

End of Parameter Definition File

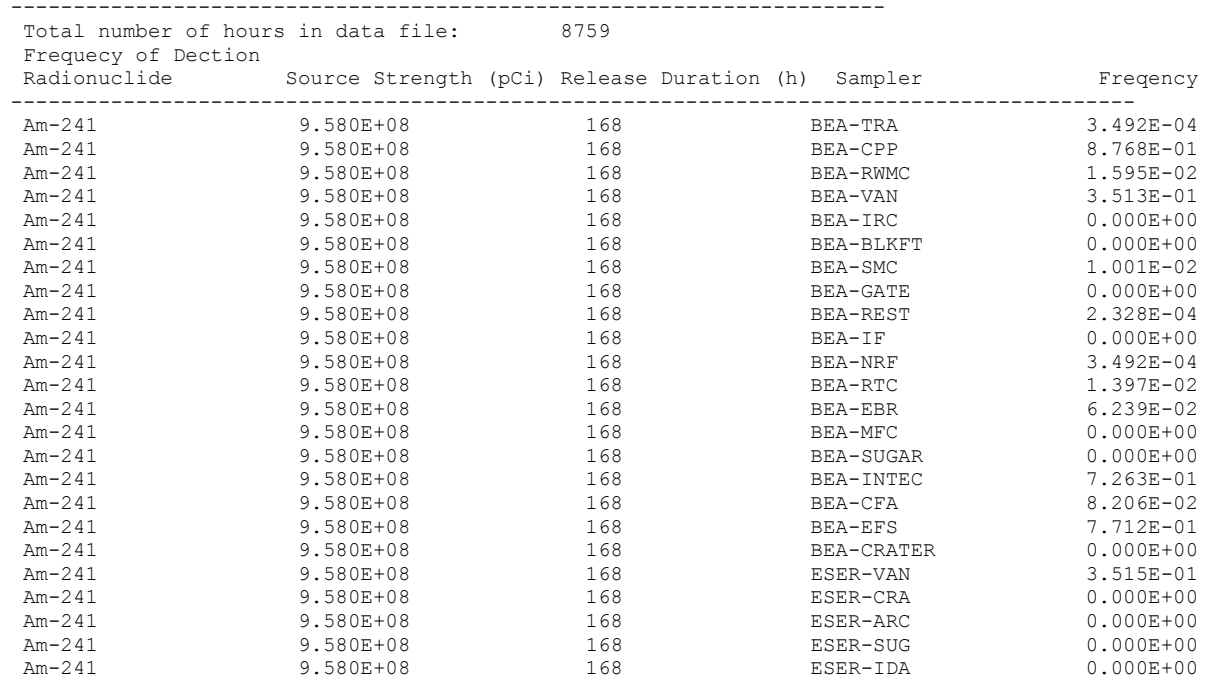




\begin{tabular}{|c|c|c|c|}
\hline$A m-241$ & $9.580 \mathrm{E}+08$ & 168 & ESER-DUB \\
\hline$A m-241$ & $9.580 \mathrm{E}+08$ & 168 & ESER-MON \\
\hline$A m-241$ & $9.580 \mathrm{E}+08$ & 168 & ESER-EFS \\
\hline$A m-241$ & $9.580 \mathrm{E}+08$ & 168 & ESER-ATO \\
\hline$A m-241$ & $9.580 \mathrm{E}+08$ & 168 & ESER-MOU \\
\hline $\mathrm{Am}-241$ & $9.580 \mathrm{E}+08$ & 168 & ESER-BLU \\
\hline Am-241 & $9.580 \mathrm{E}+08$ & 168 & ESER-TER \\
\hline$A m-241$ & $9.580 \mathrm{E}+08$ & 168 & ESER-HOW \\
\hline Am-241 & $9.580 \mathrm{E}+08$ & 168 & RWMCS \\
\hline$A m-241$ & $9.580 \mathrm{E}+08$ & 168 & $\mathrm{MFCN}$ \\
\hline $\mathrm{Am}-241$ & $9.580 \mathrm{E}+08$ & 168 & MFCGS \\
\hline Am-241 & $9.580 \mathrm{E}+08$ & 168 & Onsite_Station \\
\hline$A m-241$ & $9.580 \mathrm{E}+08$ & 168 & offsitē_station \\
\hline $\mathrm{Cs}-137$ & $8.360 \mathrm{E}+10$ & 168 & $\mathrm{BEA}-\mathrm{TRA}^{-}$ \\
\hline $\mathrm{Cs}-137$ & $8.360 \mathrm{E}+10$ & 168 & $\mathrm{BEA}-\mathrm{CPP}$ \\
\hline $\mathrm{Cs}-137$ & $8.360 \mathrm{E}+10$ & 168 & BEA-RWMC \\
\hline Cs -137 & $8.360 \mathrm{E}+10$ & 168 & BEA-VAN \\
\hline Cs -137 & $8.360 \mathrm{E}+10$ & 168 & $\mathrm{BEA}-\mathrm{IRC}$ \\
\hline Cs -137 & $8.360 \mathrm{E}+10$ & 168 & BEA-BLKFT \\
\hline Cs -137 & $8.360 \mathrm{E}+10$ & 168 & $\mathrm{BEA}-\mathrm{SMC}$ \\
\hline Cs -137 & $8.360 E+10$ & 168 & BEA-GATE \\
\hline Cs -137 & $8.360 \mathrm{E}+10$ & 168 & BEA-REST \\
\hline Cs -137 & $8.360 \mathrm{E}+10$ & 168 & $\mathrm{BEA}-\mathrm{IF}$ \\
\hline Cs -137 & $8.360 \mathrm{E}+10$ & 168 & $\mathrm{BEA}-\mathrm{NRF}$ \\
\hline Cs -137 & $8.360 \mathrm{E}+10$ & 168 & $\mathrm{BEA}-\mathrm{RTC}$ \\
\hline Cs -137 & $8.360 \mathrm{E}+10$ & 168 & $\mathrm{BEA}-\mathrm{EBR}$ \\
\hline $\mathrm{Cs}-137$ & $8.360 \mathrm{E}+10$ & 168 & $\mathrm{BEA}-\mathrm{MFC}$ \\
\hline Cs -137 & $8.360 \mathrm{E}+10$ & 168 & BEA-SUGAR \\
\hline Cs -137 & $8.360 \mathrm{E}+10$ & 168 & BEA-INTEC \\
\hline $\mathrm{Cs}-137$ & $8.360 \mathrm{E}+10$ & 168 & $\mathrm{BEA}-\mathrm{CFA}$ \\
\hline Cs -137 & $8.360 \mathrm{E}+10$ & 168 & $\mathrm{BEA}-\mathrm{EFS}$ \\
\hline Cs -137 & $8.360 \mathrm{E}+10$ & 168 & BEA-CRATER \\
\hline Cs -137 & $8.360 E+10$ & 168 & ESER-VAN \\
\hline $\mathrm{Cs}-137$ & $8.360 \mathrm{E}+10$ & 168 & ESER-CRA \\
\hline Cs -137 & $8.360 \mathrm{E}+10$ & 168 & ESER-ARC \\
\hline Cs -137 & $8.360 \mathrm{E}+10$ & 168 & ESER-SUG \\
\hline Cs -137 & $8.360 \mathrm{E}+10$ & 168 & ESER-IDA \\
\hline $\mathrm{Cs}-137$ & $8.360 \mathrm{E}+10$ & 168 & ESER-DUB \\
\hline $\mathrm{Cs}-137$ & $8.360 \mathrm{E}+10$ & 168 & ESER-MON \\
\hline $\mathrm{Cs}-137$ & $8.360 \mathrm{E}+10$ & 168 & ESER-EFS \\
\hline Cs -137 & $8.360 \mathrm{E}+10$ & 168 & ESER-ATO \\
\hline Cs -137 & $8.360 \mathrm{E}+10$ & 168 & ESER-MOU \\
\hline $\mathrm{Cs}-137$ & $8.360 \mathrm{E}+10$ & 168 & ESER-BLU \\
\hline $\mathrm{Cs}-137$ & $8.360 \mathrm{E}+10$ & 168 & ESER-TER \\
\hline $\mathrm{Cs}-137$ & $8.360 \mathrm{E}+10$ & 168 & ESER-HOW \\
\hline Cs -137 & $8.360 \mathrm{E}+10$ & 168 & RWMCS \\
\hline $\mathrm{Cs}-137$ & $8.360 \mathrm{E}+10$ & 168 & $\mathrm{MFCN}$ \\
\hline$C s-137$ & $8.360 \mathrm{E}+10$ & 168 & MFCGS \\
\hline Cs -137 & $8.360 \mathrm{E}+10$ & 168 & Onsite_Station \\
\hline Cs -137 & $8.360 \mathrm{E}+10$ & 168 & Offsitē_Station \\
\hline Pu-238 & $8.530 \mathrm{E}+08$ & 168 & BEA-TRA \\
\hline Pu-238 & $8.530 \mathrm{E}+08$ & 168 & $\mathrm{BEA}-\mathrm{CPP}$ \\
\hline Pu-238 & $8.530 \mathrm{E}+08$ & 168 & BEA-RWMC \\
\hline Pu-238 & $8.530 \mathrm{E}+08$ & 168 & BEA-VAN \\
\hline Pu-238 & $8.530 \mathrm{E}+08$ & 168 & $\mathrm{BEA}-\mathrm{IRC}$ \\
\hline Pu-238 & $8.530 E+08$ & 168 & BEA-BLKFT \\
\hline Pu-238 & $8.530 \mathrm{E}+08$ & 168 & $\mathrm{BEA}-\mathrm{SMC}$ \\
\hline Pu-238 & $8.530 \mathrm{E}+08$ & 168 & BEA-GATE \\
\hline Pu-238 & $8.530 \mathrm{E}+08$ & 168 & BEA-REST \\
\hline $\mathrm{Pu}-238$ & $8.530 E+08$ & 168 & $\mathrm{BEA}-\mathrm{IF}$ \\
\hline $\mathrm{Pu}-238$ & $8.530 \mathrm{E}+08$ & 168 & $\mathrm{BEA}-\mathrm{NRF}$ \\
\hline Pu-238 & $8.530 \mathrm{E}+08$ & 168 & $\mathrm{BEA}-\mathrm{RTC}$ \\
\hline Pu-238 & $8.530 \mathrm{E}+08$ & 168 & $\mathrm{BEA}-\mathrm{EBR}$ \\
\hline Pu-238 & $8.530 \mathrm{E}+08$ & 168 & $\mathrm{BEA}-\mathrm{MFC}$ \\
\hline Pu-238 & $8.530 \mathrm{E}+08$ & 168 & BEA-SUGAR \\
\hline Pu-238 & $8.530 \mathrm{E}+08$ & 168 & BEA-INTEC \\
\hline $\mathrm{Pu}-238$ & $8.530 \mathrm{E}+08$ & 168 & $\mathrm{BEA}-\mathrm{CFA}$ \\
\hline $\mathrm{Pu}-238$ & $8.530 \mathrm{E}+08$ & 168 & $\mathrm{BEA}-\mathrm{EFS}$ \\
\hline Pu-238 & $8.530 \mathrm{E}+08$ & 168 & BEA-CRATER \\
\hline $\mathrm{Pu}-238$ & $8.530 \mathrm{E}+08$ & 168 & ESER-VAN \\
\hline Pu-238 & $8.530 \mathrm{E}+08$ & 168 & ESER-CRA \\
\hline Pu-238 & $8.530 \mathrm{E}+08$ & 168 & ESER-ARC \\
\hline Pu-238 & $8.530 \mathrm{E}+08$ & 168 & ESER-SUG \\
\hline $\mathrm{Pu}-238$ & $8.530 \mathrm{E}+08$ & 168 & ESER-IDA \\
\hline Pu-238 & $8.530 \mathrm{E}+08$ & 168 & ESER-DUB \\
\hline Pu-238 & $8.530 E+08$ & 168 & ESER-MON \\
\hline $\mathrm{Pu}-238$ & $8.530 E+08$ & 168 & ESER-EFS \\
\hline Pu-238 & $8.530 \mathrm{E}+08$ & 168 & ESER-ATO \\
\hline Pu-238 & $8.530 \mathrm{E}+08$ & 168 & ESER-MOU \\
\hline $\mathrm{Pu}-238$ & $8.530 E+08$ & 168 & ESER-BLU \\
\hline Pu-238 & $8.530 \mathrm{E}+08$ & 168 & ESER-TER \\
\hline Pu-238 & $8.530 \mathrm{E}+08$ & 168 & ESER-HOW \\
\hline $\mathrm{Pu}-238$ & $8.530 \mathrm{E}+08$ & 168 & RWMCS \\
\hline Pu-238 & $8.530 \mathrm{E}+08$ & 168 & $\mathrm{MFCN}$ \\
\hline Pu-238 & $8.530 \mathrm{E}+08$ & 168 & MFCGS \\
\hline Pu-238 & $8.530 \mathrm{E}+08$ & 168 & Onsite_station \\
\hline $\mathrm{Pu}-238$ & $8.530 \mathrm{E}+08$ & 168 & Offsite Station \\
\hline $\mathrm{Pu}-239$ & $7.760 \mathrm{E}+08$ & 168 & BEA-TRA- \\
\hline Pu-239 & $7.760 \mathrm{E}+08$ & 168 & $\mathrm{BEA}-\mathrm{CPP}$ \\
\hline Pu-239 & $7.760 \mathrm{E}+08$ & 168 & BEA-RWMC \\
\hline Pu-239 & $7.760 \mathrm{E}+08$ & 168 & BEA-VAN \\
\hline Pu-239 & $7.760 \mathrm{E}+08$ & 168 & $\mathrm{BEA}-\mathrm{IRC}$ \\
\hline $\mathrm{Pu}-239$ & $7.760 \mathrm{E}+08$ & 168 & BEA-BLKFT \\
\hline $\mathrm{Pu}-239$ & $7.760 \mathrm{E}+08$ & 168 & BEA-SMC \\
\hline Pu-239 & $7.760 \mathrm{E}+08$ & 168 & $\mathrm{BEA}-\mathrm{GATE}$ \\
\hline
\end{tabular}




\begin{tabular}{|c|c|c|c|}
\hline Pu-239 & $7.760 \mathrm{E}+08$ & 168 & BEA-REST \\
\hline Pu-239 & $7.760 \mathrm{E}+08$ & 168 & $\mathrm{BEA}-\mathrm{IF}$ \\
\hline Pu-239 & $7.760 \mathrm{E}+08$ & 168 & $\mathrm{BEA}-\mathrm{NRF}$ \\
\hline Pu-239 & $7.760 \mathrm{E}+08$ & 168 & $\mathrm{BEA}-\mathrm{RTC}$ \\
\hline Pu-239 & $7.760 \mathrm{E}+08$ & 168 & $\mathrm{BEA}-\mathrm{EBR}$ \\
\hline Pu-239 & $7.760 \mathrm{E}+08$ & 168 & $\mathrm{BEA}-\mathrm{MFC}$ \\
\hline Pu-239 & $7.760 \mathrm{E}+08$ & 168 & BEA-SUGAR \\
\hline Pu-239 & $7.760 \mathrm{E}+08$ & 168 & BEA-INTEC \\
\hline Pu-239 & $7.760 \mathrm{E}+08$ & 168 & $\mathrm{BEA}-\mathrm{CFA}$ \\
\hline Pu-239 & $7.760 \mathrm{E}+08$ & 168 & $B E A-E F S$ \\
\hline Pu-239 & $7.760 \mathrm{E}+08$ & 168 & BEA-CRATER \\
\hline Pu-239 & $7.760 \mathrm{E}+08$ & 168 & ESER-VAN \\
\hline Pu-239 & $7.760 \mathrm{E}+08$ & 168 & ESER-CRA \\
\hline Pu-239 & $7.760 \mathrm{E}+08$ & 168 & ESER-ARC \\
\hline Pu-239 & $7.760 \mathrm{E}+08$ & 168 & ESER-SUG \\
\hline Pu-239 & $7.760 \mathrm{E}+08$ & 168 & ESER-IDA \\
\hline Pu-239 & $7.760 \mathrm{E}+08$ & 168 & ESER-DUB \\
\hline Pu-239 & $7.760 \mathrm{E}+08$ & 168 & ESER-MON \\
\hline Pu-239 & $7.760 \mathrm{E}+08$ & 168 & ESER-EFS \\
\hline Pu-239 & $7.760 \mathrm{E}+08$ & 168 & ESER-ATO \\
\hline Pu-239 & $7.760 \mathrm{E}+08$ & 168 & ESER-MOU \\
\hline Pu-239 & $7.760 \mathrm{E}+08$ & 168 & ESER-BLU \\
\hline Pu-239 & $7.760 \mathrm{E}+08$ & 168 & ESER-TER \\
\hline Pu-239 & $7.760 \mathrm{E}+08$ & 168 & ESER-HOW \\
\hline Pu-239 & $7.760 \mathrm{E}+08$ & 168 & RWMCS \\
\hline $\mathrm{Pu}-239$ & $7.760 \mathrm{E}+08$ & 168 & $\mathrm{MFCN}$ \\
\hline Pu-239 & $7.760 \mathrm{E}+08$ & 168 & MFCGS \\
\hline Pu-239 & $7.760 \mathrm{E}+08$ & 168 & Onsite_station \\
\hline Pu-239 & $7.760 \mathrm{E}+08$ & 168 & offsité_Station \\
\hline $\mathrm{Sr}-90$ & $3.200 \mathrm{E}+10$ & 168 & $\mathrm{BEA}-\mathrm{TRA}{ }^{-}$ \\
\hline Sr -90 & $3.200 \mathrm{E}+10$ & 168 & $\mathrm{BEA}-\mathrm{CPP}$ \\
\hline $\mathrm{Sr}-90$ & $3.200 \mathrm{E}+10$ & 168 & BEA-RWMC \\
\hline $\mathrm{Sr}-90$ & $3.200 \mathrm{E}+10$ & 168 & BEA-VAN \\
\hline $\mathrm{Sr}-90$ & $3.200 \mathrm{E}+10$ & 168 & BEA-IRC \\
\hline $\mathrm{Sr}-90$ & $3.200 \mathrm{E}+10$ & 168 & BEA-BLKFT \\
\hline Sr -90 & $3.200 \mathrm{E}+10$ & 168 & BEA-SMC \\
\hline $\mathrm{Sr}-90$ & $3.200 \mathrm{E}+10$ & 168 & BEA-GATE \\
\hline $\mathrm{Sr}-90$ & $3.200 \mathrm{E}+10$ & 168 & BEA-REST \\
\hline $\mathrm{Sr}-90$ & $3.200 \mathrm{E}+10$ & 168 & $\mathrm{BEA}-\mathrm{IF}$ \\
\hline $\mathrm{Sr}-90$ & $3.200 \mathrm{E}+10$ & 168 & BEA-NRF \\
\hline $\mathrm{Sr}-90$ & $3.200 \mathrm{E}+10$ & 168 & BEA-RTC \\
\hline Sr-90 & $3.200 \mathrm{E}+10$ & 168 & $\mathrm{BEA}-\mathrm{EBR}$ \\
\hline $\mathrm{Sr}-90$ & $3.200 \mathrm{E}+10$ & 168 & BEA-MFC \\
\hline $\mathrm{Sr}-90$ & $3.200 \mathrm{E}+10$ & 168 & BEA-SUGAR \\
\hline $\mathrm{Sr}-90$ & $3.200 \mathrm{E}+10$ & 168 & BEA-INTEC \\
\hline $\mathrm{Sr}-90$ & $3.200 \mathrm{E}+10$ & 168 & $\mathrm{BEA}-\mathrm{CFA}$ \\
\hline $\mathrm{Sr}-90$ & $3.200 \mathrm{E}+10$ & 168 & BEA-EFS \\
\hline $\mathrm{Sr}-90$ & $3.200 \mathrm{E}+10$ & 168 & BEA-CRATER \\
\hline $\mathrm{Sr}-90$ & $3.200 \mathrm{E}+10$ & 168 & ESER-VAN \\
\hline Sr -90 & $3.200 \mathrm{E}+10$ & 168 & ESER-CRA \\
\hline $\mathrm{Sr}-90$ & $3.200 \mathrm{E}+10$ & 168 & ESER-ARC \\
\hline $\mathrm{Sr}-90$ & $3.200 \mathrm{E}+10$ & 168 & ESER-SUG \\
\hline $\mathrm{Sr}-90$ & $3.200 \mathrm{E}+10$ & 168 & ESER-IDA \\
\hline $\mathrm{Sr}-90$ & $3.200 \mathrm{E}+10$ & 168 & ESER-DUB \\
\hline $\mathrm{Sr}-90$ & $3.200 \mathrm{E}+10$ & 168 & ESER-MON \\
\hline $\mathrm{Sr}-90$ & $3.200 \mathrm{E}+10$ & 168 & ESER-EFS \\
\hline $\mathrm{Sr}-90$ & $3.200 \mathrm{E}+10$ & 168 & ESER-ATO \\
\hline $\mathrm{Sr}-90$ & $3.200 \mathrm{E}+10$ & 168 & ESER-MOU \\
\hline Sr -90 & $3.200 \mathrm{E}+10$ & 168 & ESER-BLU \\
\hline Sr -90 & $3.200 \mathrm{E}+10$ & 168 & ESER-TER \\
\hline $\mathrm{Sr}-90$ & $3.200 \mathrm{E}+10$ & 168 & ESER-HOW \\
\hline $\mathrm{Sr}-90$ & $3.200 \mathrm{E}+10$ & 168 & RWMCS \\
\hline $\mathrm{Sr}-90$ & $3.200 \mathrm{E}+10$ & 168 & $\mathrm{MFCN}$ \\
\hline Sr -90 & $3.200 \mathrm{E}+10$ & 168 & MFCGS \\
\hline $\mathrm{Sr}-90$ & $3.200 \mathrm{E}+10$ & 168 & Onsite Station \\
\hline $\mathrm{Sr}-90$ & $3.200 \mathrm{E}+10$ & 168 & Offsite Station \\
\hline I-131 & $2.130 \mathrm{E}+11$ & 168 & BEA-TRA \\
\hline$I-131$ & $2.130 \mathrm{E}+11$ & 168 & $\mathrm{BEA}-\mathrm{CPP}$ \\
\hline I-131 & $2.130 \mathrm{E}+11$ & 168 & BEA-RWMC \\
\hline I-131 & $2.130 \mathrm{E}+11$ & 168 & BEA-VAN \\
\hline I-131 & $2.130 \mathrm{E}+11$ & 168 & $\mathrm{BEA}-\mathrm{IRC}$ \\
\hline I-131 & $2.130 \mathrm{E}+11$ & 168 & BEA-BLKFT \\
\hline I-131 & $2.130 \mathrm{E}+11$ & 168 & BEA-SMC \\
\hline$I-131$ & $2.130 \mathrm{E}+11$ & 168 & BEA-GATE \\
\hline I-131 & $2.130 \mathrm{E}+11$ & 168 & $\mathrm{BEA}-\mathrm{REST}$ \\
\hline$I-131$ & $2.130 \mathrm{E}+11$ & 168 & $\mathrm{BEA}-\mathrm{IF}$ \\
\hline$I-131$ & $2.130 \mathrm{E}+11$ & 168 & BEA-NRF \\
\hline I-131 & $2.130 \mathrm{E}+11$ & 168 & BEA-RTC \\
\hline I-131 & $2.130 \mathrm{E}+11$ & 168 & $\mathrm{BEA}-\mathrm{EBR}$ \\
\hline$I-131$ & $2.130 \mathrm{E}+11$ & 168 & $\mathrm{BEA}-\mathrm{MFC}$ \\
\hline$I-131$ & $2.130 \mathrm{E}+11$ & 168 & BEA-SUGAR \\
\hline I-131 & $2.130 \mathrm{E}+11$ & 168 & BEA-INTEC \\
\hline I-131 & $2.130 \mathrm{E}+11$ & 168 & $\mathrm{BEA}-\mathrm{CFA}$ \\
\hline I-131 & $2.130 \mathrm{E}+11$ & 168 & BEA-EFS \\
\hline I-131 & $2.130 \mathrm{E}+11$ & 168 & BEA-CRATER \\
\hline I-131 & $2.130 \mathrm{E}+11$ & 168 & ESER-VAN \\
\hline I-131 & $2.130 \mathrm{E}+11$ & 168 & ESER-CRA \\
\hline I-131 & $2.130 \mathrm{E}+11$ & 168 & ESER-ARC \\
\hline I-131 & $2.130 \mathrm{E}+11$ & 168 & ESER-SUG \\
\hline I-131 & $2.130 \mathrm{E}+11$ & 168 & ESER-IDA \\
\hline I-131 & $2.130 \mathrm{E}+11$ & 168 & ESER-DUB \\
\hline$I-131$ & $2.130 \mathrm{E}+11$ & 168 & ESER-MON \\
\hline I-131 & $2.130 \mathrm{E}+11$ & 168 & ESER-EFS \\
\hline I-131 & $2.130 \mathrm{E}+11$ & 168 & ESER-ATO \\
\hline I-131 & $2.130 \mathrm{E}+11$ & 168 & ESER-MOU \\
\hline
\end{tabular}




\begin{tabular}{|c|c|c|c|c|c|}
\hline I-131 & $2.130 \mathrm{E}+11$ & 168 & ESER-BLU & $5.088 \mathrm{E}-01$ & \\
\hline$I-131$ & $2.130 \mathrm{E}+11$ & 168 & ESER-TER & $8.704 \mathrm{E}-01$ & \\
\hline$I-131$ & $2.130 \mathrm{E}+11$ & 168 & ESER-HOW & $7.749 \mathrm{E}-01$ & \\
\hline I-131 & $2.130 \mathrm{E}+11$ & 168 & RWMCS & $9.709 \mathrm{E}-01$ & \\
\hline I-131 & $2.130 \mathrm{E}+11$ & 168 & $\mathrm{MFCN}$ & $6.729 \mathrm{E}-01$ & \\
\hline I-131 & $2.130 \mathrm{E}+11$ & 168 & MFCGS & $6.416 \mathrm{E}-01$ & \\
\hline$I-131$ & $2.130 \mathrm{E}+11$ & 168 & Onsite_Station & $1.000 \mathrm{E}+00$ & $7.049 \mathrm{E}-01$ \\
\hline$I-131$ & $2.130 \mathrm{E}+11$ & 168 & Offsitē_Station & $0.000 \mathrm{E}+00$ & $0.000 \mathrm{E}+00$ \\
\hline
\end{tabular}

RESIDENT SCENARIO, EXISTING NETWORK, OPTIMIZED FOR CPP-1774

\begin{tabular}{|c|c|}
\hline & This output was produced by the model: \\
\hline & FREQD \\
\hline & FREQuency of Detection program for INL sources \\
\hline & and air monitoring network. \\
\hline & Version date (yyyymmdd): \\
\hline & 20141120 \\
\hline & Arthur S. Rood \\
\hline & K-Spar Inc. 4835 W Foxtrail Lane \\
\hline & Idaho Falls, ID 83402 \\
\hline & asr@kspar.com \\
\hline
\end{tabular}

Date: 05/16/2015 Time: 21:23:15.680

Input File: freqd.par

START OF PARAMETER DEFINITION FILE

FreqD.f95 - Evaluation of existing network for 168-hr release yielding $1 \mathrm{mrem} / \mathrm{yr}$ Data File:../././TICSALL/CPP-1774 combine.txt

67

\begin{tabular}{|c|c|c|c|c|c|c|c|c|c|}
\hline \multirow{2}{*}{$\begin{array}{l}\text { BEA-TRA } \\
\text { BEA-CPP }\end{array}$} & 3.398 & 168 & 1 & 1 & sampname, & , flowr, & , rtime, & onsite, & , incsamp \\
\hline & 3.398 & 168 & 1 & 1 & sampname, & , flowr, & , rtime, & onsite, & , incsamp \\
\hline BEA-RWMC & 3.398 & 168 & 1 & 1 & sampname, & , flowr, & , rtime, & onsite, & incsamp \\
\hline BEA-VAN & 3.398 & 168 & 1 & 1 & sampname, & , flowr, & , rtime, & onsite, & , incsamp \\
\hline \multirow{2}{*}{$\begin{array}{l}\text { BEA-IRC } \\
\text { BEA-BLKFT }\end{array}$} & 3.398 & 168 & 1 & 1 & sampname, & , flowr, & , rtime, & onsite, & , incsamp \\
\hline & 3.398 & 168 & 1 & 1 & sampname, & , flowr, & , rtime, & onsite, & , incsamp \\
\hline BEA-SMC & 3.398 & 168 & 1 & 1 & sampname, & , flowr, & , rtime, & onsite, & , incsamp \\
\hline BEA-GATE & 3.398 & 168 & 1 & 1 & sampname, & , flowr, & , rtime, & onsite, & , incsamp \\
\hline BEA-ARA & 3.398 & 168 & 1 & 0 & sampname, & , flowr, & , rtime, & onsite, & , incsamp \\
\hline BEA-REST & 3.398 & 168 & 1 & 1 & sampname, & , flowr, & , rtime, & onsite, & incsamp \\
\hline \multirow{2}{*}{$\begin{array}{l}\text { BEA-IF } \\
\text { BEA-NRF }\end{array}$} & 3.398 & 168 & 1 & 1 & sampname, & , flowr, & , rtime, & onsite, & , incsamp \\
\hline & 3.398 & 168 & 1 & 1 & sampname, & , flowr, & , rtime, & onsite, & , incsamp \\
\hline $\mathrm{BEA}-\mathrm{RTC}$ & 3.398 & 168 & 1 & 1 & sampname, & , flowr, & , rtime, & onsite, & , incsamp \\
\hline \multirow{2}{*}{$\begin{array}{l}\text { BEA-EBR } \\
\text { BEA-MFC }\end{array}$} & 3.398 & 168 & 1 & 1 & sampname, & , flowr, & , rtime, & onsite, & , incsamp \\
\hline & 3.398 & 168 & 1 & 1 & sampname, & , flowr, & , rtime, & onsite, & , incsamp \\
\hline BEA-SUGAR & 3.398 & 168 & 1 & 1 & sampname, & , flowr, & , rtime, & onsite, & , incsamp \\
\hline $\mathrm{BEA}-\mathrm{PBF}$ & 3.398 & 168 & 1 & 0 & sampname, & , flowr, & , rtime, & onsite, & incsamp \\
\hline BEA-INTEC & 3.398 & 168 & 1 & 1 & sampname, & , flowr, & , rtime, & onsite, & , incsamp \\
\hline $\mathrm{BEA}-\mathrm{CFA}$ & 3.398 & 168 & 1 & 1 & sampname, & , flowr, & , rtime, & onsite, & , incsamp \\
\hline $\mathrm{BEA}-\mathrm{EFS}$ & 3.398 & 168 & 1 & 1 & sampname, & , flowr, & , rtime, & onsite, & , incsamp \\
\hline BEA-CRATE & 3.39 & 168 & 1 & 1 & sampname, & , flowr, & , rtime, & onsite, & , incsamp \\
\hline ESER-VAN & 3.398 & 168 & 1 & 1 & sampname, & , flowr, & , rtime, & onsite, & , incsamp \\
\hline ESER-CRA & 3.398 & 168 & 1 & 1 & sampname, & , flowr, & , rtime, & onsite, & incsamp \\
\hline ESER-ARC & 3.398 & 168 & 1 & 1 & sampname, & flowr, & , rtime, & onsite, & incsamp \\
\hline ESER-SUG & 3.398 & 168 & 1 & 1 & sampname, & , flowr, & , rtime, & onsite, & , incsamp \\
\hline ESER-IDA & 3.398 & 168 & 1 & 1 & sampname, & , flowr, & , rtime, & onsite, & , incsamp \\
\hline ESER-DUB & 3.398 & 168 & 1 & 1 & sampname, & , flowr, & , rtime, & onsite, & , incsamp \\
\hline ESER-MON & 3.398 & 168 & 1 & 1 & sampname, & , flowr, & , rtime, & onsite, & incsamp \\
\hline ESER-FAA & 3.398 & 168 & 1 & 0 & sampname, & , flowr, & , rtime, & onsite, & , incsamp \\
\hline ESER-MAI & 3.398 & 168 & 1 & 0 & sampname, & flowr, & , rtime, & onsite, & incsamp \\
\hline ESER-EFS & 3.398 & 168 & 1 & 1 & sampname, & , flowr, & , rtime, & , onsite, & , incsamp \\
\hline ESER-ATO & 3.398 & 168 & 1 & 1 & sampname, & , flowr, & , rtime, & , onsite, & , incsamp \\
\hline ESER-MOU & 3.398 & 168 & 1 & 1 & sampname, & flowr, & rtime, & onsite, & incsamp \\
\hline ESER-BLU & 3.398 & 168 & 1 & 1 & sampname, & , flowr, & , rtime, & , onsite, & , incsamp \\
\hline ESER-TER & 3.398 & 168 & 1 & 1 & sampname, & , flowr, & , rtime, & , onsite, & incsamp \\
\hline ESER-HOW & 3.398 & 168 & 1 & 1 & sampname, & , flowr, & , rtime, & , onsite, & incsamp \\
\hline MEI01 & 3.398 & 168 & 1 & & mpname, $f$ & wr, & ime, & site, & csamp \\
\hline MEI02 & .398 & 168 & 1 & 0 & mpname, & wr, & me, & ite, & samp \\
\hline EI03 & 3.398 & 168 & 1 & 0 & sampname, $f$ & flowr, $r$ & rtime, o & onsite, i & incsamp \\
\hline MEIO 4 & 3998 & 168 & 1 & 0 & ampname, $\mathrm{f}$ & flowr, $r$ & rtime, & onsite, i & incsamp \\
\hline 105 & 3.398 & 168 & 1 & 0 & ampname, $f$ & flowr, $r$ & rtime, & onsite, i & incsamp \\
\hline 106 & .398 & 168 & 1 & 0 & ampname, $f$ & flowr, $r$ & rtime, & onsite, i & incsamp \\
\hline MEI07 & .398 & 168 & 1 & 0 & sampname, f & flowr, $r$ & rtime, & onsite, i & incsamp \\
\hline 108 & 3.398 & 168 & 1 & 0 & sampname, $f$ & flowr, $r$ & rtime, & onsite, i & incsamp \\
\hline MEI09 & .398 & 168 & 1 & 0 & sampname, $f$ & flowr, $r$ & rtime, & onsite, i & incsamp \\
\hline MEI10 & .398 & 168 & 1 & 0 & sampname, $f$ & flowr, $r$ & rtime, & onsite, i & incsamp \\
\hline 717 & 3.398 & 168 & 1 & 0 & sampname, $f$ & flowr, $r$ & rtime, o & onsite, i & incsamp \\
\hline $\operatorname{MEI} 12$ & 3.398 & 168 & 1 & 0 & sampname, $f$ & flowr, $r$ & rtime, & onsite, i & incsamp \\
\hline $\operatorname{MEI} 13$ & 3.398 & 168 & 1 & 0 & sampname, $f$ & flowr, $r$ & rtime, 0 & onsite, i & incsamp \\
\hline 414 & 3.398 & 168 & 1 & 0 & sampname, $f$ & flowr, $r$ & rtime, & onsite, i & incs \\
\hline MEI15 & .398 & 168 & 1 & 0 & sampname, f & flowr, $r$ & rtime, & onsite, i & incsamp \\
\hline MEI16 & 3.398 & 168 & 1 & 0 & sampname, $f$ & flowr, $r$ & rtime, & onsite, i & incsamp \\
\hline MEI17 & 3.398 & 168 & 1 & 0 & sampname, $f$ & flowr, $r$ & rtime, & onsite, i & incsamp \\
\hline MEI18 & 3.398 & 168 & 1 & 0 & sampname, $f$ & flowr, $r$ & rtime, & onsite, i & incsamp \\
\hline MEI19 & 3.398 & 168 & 1 & 0 & sampname, $f$ & flowr, $r$ & rtime, o & onsite, i & incsamp \\
\hline MEI20 & 3.398 & 168 & 1 & 0 & sampname, f & flowr, $r$ & rtime, & onsite, i & incsamp \\
\hline $\operatorname{MEI} 21$ & 3.398 & 168 & 1 & 0 & sampname, $f$ & flowr, $r$ & rtime, & onsite, i & incsamp \\
\hline MEI22 & 3.398 & 168 & 1 & 0 & sampname, $f$ & flowr, $r$ & rtime, & onsite, i & incsamp \\
\hline EI23 & 3.398 & 168 & 1 & 0 & sampname, $f$ & flowr, $r$ & rtime, o & onsite, i & incsamp \\
\hline 124 & 3.398 & 168 & 1 & 0 & sampname, f & flowr, $r$ & rtime, & onsite, i & incsamp \\
\hline & 3.398 & 168 & 1 & 0 & sampname, $f$ & flowr, $r$ & rtime, & onsite, i & incsamp \\
\hline 120 & 398 & 168 & & & sampname, f & & rtime, & onsite, & incsamp \\
\hline
\end{tabular}




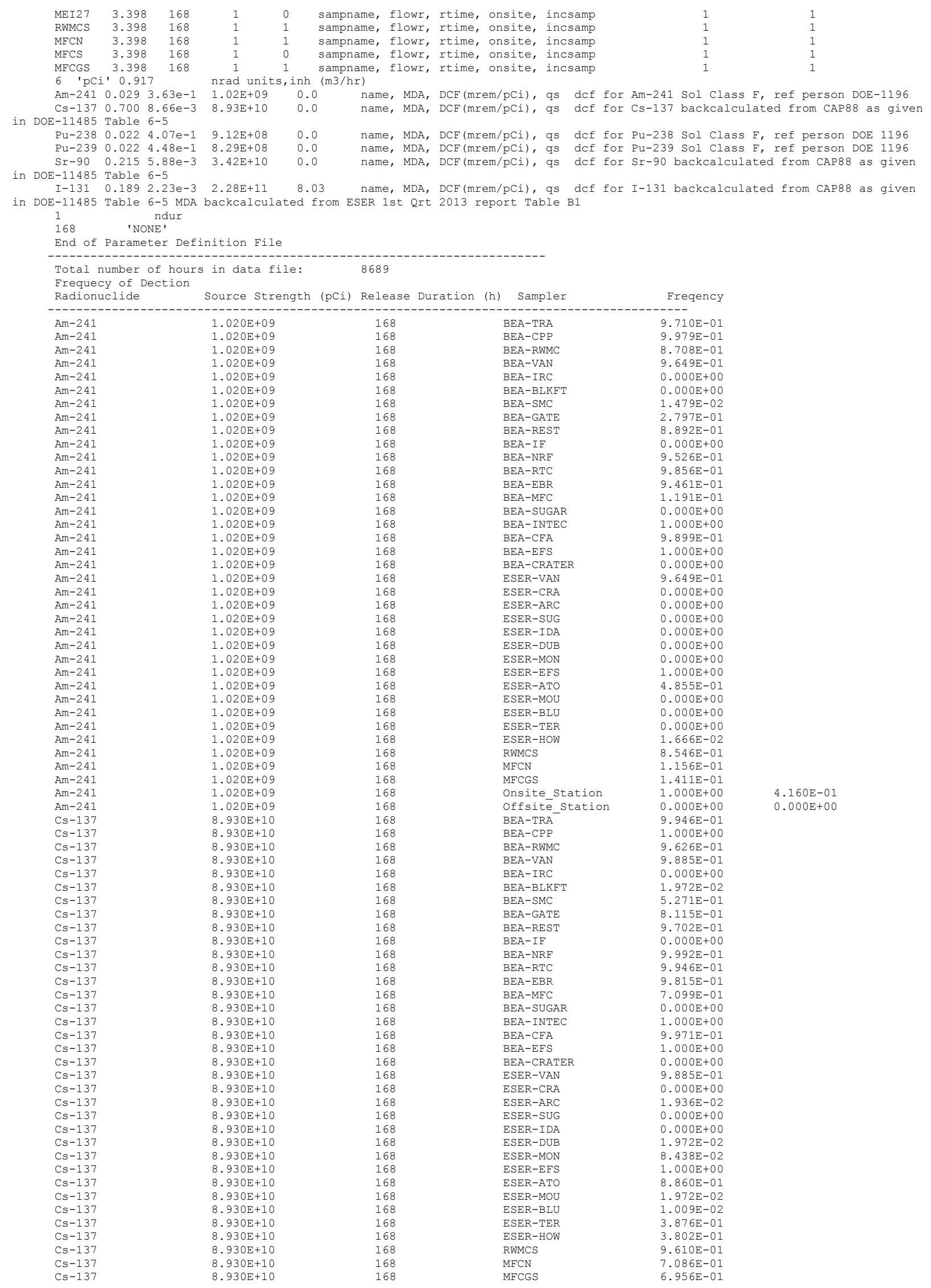




\begin{tabular}{|c|c|c|c|}
\hline Cs -137 & $8.930 E+10$ & 168 & Onsite_Station \\
\hline $\mathrm{Cs}-137$ & $8.930 E+10$ & 168 & Offsite_station \\
\hline $\mathrm{Pu}-238$ & $9.120 \mathrm{E}+08$ & 168 & BEA-TRA ${ }^{-}$ \\
\hline $\mathrm{Pu}-238$ & $9.120 \mathrm{E}+08$ & 168 & $\mathrm{BEA}-\mathrm{CPP}$ \\
\hline Pu-238 & $9.120 \mathrm{E}+08$ & 168 & BEA-RWMC \\
\hline $\mathrm{Pu}-238$ & $9.120 \mathrm{E}+08$ & 168 & BEA-VAN \\
\hline Pu-238 & $9.120 \mathrm{E}+08$ & 168 & $B E A-I R C$ \\
\hline Pu-238 & $9.120 \mathrm{E}+08$ & 168 & BEA-BLKFT \\
\hline $\mathrm{Pu}-238$ & $9.120 \mathrm{E}+08$ & 168 & BEA-SMC \\
\hline Pu-238 & $9.120 \mathrm{E}+08$ & 168 & BEA-GATE \\
\hline Pu-238 & $9.120 \mathrm{E}+08$ & 168 & BEA-REST \\
\hline Pu-238 & $9.120 \mathrm{E}+08$ & 168 & $B E A-I F$ \\
\hline Pu-238 & $9.120 \mathrm{E}+08$ & 168 & BEA-NRF \\
\hline $\mathrm{Pu}-238$ & $9.120 \mathrm{E}+08$ & 168 & BEA-RTC \\
\hline Pu-238 & $9.120 \mathrm{E}+08$ & 168 & $\mathrm{BEA}-\mathrm{EBR}$ \\
\hline $\mathrm{Pu}-238$ & $9.120 \mathrm{E}+08$ & 168 & BEA-MFC \\
\hline Pu-238 & $9.120 \mathrm{E}+08$ & 168 & BEA-SUGAR \\
\hline Pu-238 & $9.120 \mathrm{E}+08$ & 168 & BEA-INTEC \\
\hline Pu -238 & $9.120 \mathrm{E}+08$ & 168 & $\mathrm{BEA}-\mathrm{CFA}$ \\
\hline $\mathrm{Pu}-238$ & $9.120 \mathrm{E}+08$ & 168 & BEA-EFS \\
\hline $\mathrm{Pu}-238$ & $9.120 \mathrm{E}+08$ & 168 & BEA-CRATER \\
\hline $\mathrm{Pu}-238$ & $9.120 \mathrm{E}+08$ & 168 & ESER-VAN \\
\hline $\mathrm{Pu}-238$ & $9.120 \mathrm{E}+08$ & 168 & ESER-CRA \\
\hline $\mathrm{Pu}-238$ & $9.120 \mathrm{E}+08$ & 168 & ESER-ARC \\
\hline $\mathrm{Pu}-238$ & $9.120 \mathrm{E}+08$ & 168 & ESER-SUG \\
\hline Pu-238 & $9.120 \mathrm{E}+08$ & 168 & ESER-IDA \\
\hline $\mathrm{Pu}-238$ & $9.120 \mathrm{E}+08$ & 168 & ESER-DUB \\
\hline $\mathrm{Pu}-238$ & $9.120 \mathrm{E}+08$ & 168 & ESER-MON \\
\hline Pu-238 & $9.120 \mathrm{E}+08$ & 168 & ESER-EFS \\
\hline Pu-238 & $9.120 \mathrm{E}+08$ & 168 & ESER-ATO \\
\hline Pu-238 & $9.120 \mathrm{E}+08$ & 168 & ESER-MOU \\
\hline Pu -238 & $9.120 \mathrm{E}+08$ & 168 & ESER-BLU \\
\hline Pu-238 & $9.120 \mathrm{E}+08$ & 168 & ESER-TER \\
\hline $\mathrm{Pu}-238$ & $9.120 \mathrm{E}+08$ & 168 & ESER-HOW \\
\hline Pu-238 & $9.120 \mathrm{E}+08$ & 168 & RWMCS \\
\hline $\mathrm{Pu}-238$ & $9.120 \mathrm{E}+08$ & 168 & $\mathrm{MFCN}$ \\
\hline $\mathrm{Pu}-238$ & $9.120 \mathrm{E}+08$ & 168 & MFCGS \\
\hline $\mathrm{Pu}-238$ & $9.120 \mathrm{E}+08$ & 168 & Onsite Station \\
\hline Pu-238 & $9.120 \mathrm{E}+08$ & 168 & Offsitéstation \\
\hline $\mathrm{Pu}-239$ & $8.290 \mathrm{E}+08$ & 168 & $\mathrm{BEA}-\mathrm{TRA}$ \\
\hline $\mathrm{Pu}-239$ & $8.290 \mathrm{E}+08$ & 168 & $\mathrm{BEA}-\mathrm{CPP}$ \\
\hline Pu-239 & $8.290 \mathrm{E}+08$ & 168 & BEA-RWMC \\
\hline $\mathrm{Pu}-239$ & $8.290 \mathrm{E}+08$ & 168 & BEA-VAN \\
\hline Pu-239 & $8.290 \mathrm{E}+08$ & 168 & BEA-IRC \\
\hline $\mathrm{Pu}-239$ & $8.290 \mathrm{E}+08$ & 168 & BEA-BLKFT \\
\hline Pu-239 & $8.290 \mathrm{E}+08$ & 168 & $\mathrm{BEA}-\mathrm{SMC}$ \\
\hline $\mathrm{Pu}-239$ & $8.290 \mathrm{E}+08$ & 168 & $\mathrm{BEA}-\mathrm{GATE}$ \\
\hline $\mathrm{Pu}-239$ & $8.290 \mathrm{E}+08$ & 168 & BEA-REST \\
\hline Pu-239 & $8.290 \mathrm{E}+08$ & 168 & $\mathrm{BEA}-\mathrm{IF}$ \\
\hline Pu-239 & $8.290 \mathrm{E}+08$ & 168 & BEA-NRF \\
\hline Pu-239 & $8.290 \mathrm{E}+08$ & 168 & BEA-RTC \\
\hline $\mathrm{Pu}-239$ & $8.290 \mathrm{E}+08$ & 168 & BEA-EBR \\
\hline Pu-239 & $8.290 \mathrm{E}+08$ & 168 & BEA-MFC \\
\hline Pu-239 & $8.290 \mathrm{E}+08$ & 168 & BEA-SUGAR \\
\hline $\mathrm{Pu}-239$ & $8.290 \mathrm{E}+08$ & 168 & BEA-INTEC \\
\hline $\mathrm{Pu}-239$ & $8.290 \mathrm{E}+08$ & 168 & $\mathrm{BEA}-\mathrm{CFA}$ \\
\hline Pu-239 & $8.290 \mathrm{E}+08$ & 168 & BEA-EFS \\
\hline $\mathrm{Pu}-239$ & $8.290 \mathrm{E}+08$ & 168 & BEA-CRATER \\
\hline Pu-239 & $8.290 \mathrm{E}+08$ & 168 & ESER-VAN \\
\hline Pu-239 & $8.290 \mathrm{E}+08$ & 168 & ESER-CRA \\
\hline $\mathrm{Pu}-239$ & $8.290 \mathrm{E}+08$ & 168 & ESER-ARC \\
\hline Pu-239 & $8.290 \mathrm{E}+08$ & 168 & ESER-SUG \\
\hline Pu-239 & $8.290 \mathrm{E}+08$ & 168 & ESER-IDA \\
\hline Pu-239 & $8.290 \mathrm{E}+08$ & 168 & ESER-DUB \\
\hline $\mathrm{Pu}-239$ & $8.290 \mathrm{E}+08$ & 168 & ESER-MON \\
\hline $\mathrm{Pu}-239$ & $8.290 \mathrm{E}+08$ & 168 & ESER-EFS \\
\hline $\mathrm{Pu}-239$ & $8.290 \mathrm{E}+08$ & 168 & ESER-ATO \\
\hline Pu-239 & $8.290 \mathrm{E}+08$ & 168 & ESER-MOU \\
\hline $\mathrm{Pu}-239$ & $8.290 \mathrm{E}+08$ & 168 & ESER-BLU \\
\hline Pu-239 & $8.290 \mathrm{E}+08$ & 168 & ESER-TER \\
\hline Pu-239 & $8.290 \mathrm{E}+08$ & 168 & ESER-HOW \\
\hline $\mathrm{Pu}-239$ & $8.290 \mathrm{E}+08$ & 168 & RWMCS \\
\hline Pu-239 & $8.290 \mathrm{E}+08$ & 168 & $\mathrm{MFCN}$ \\
\hline Pu-239 & $8.290 \mathrm{E}+08$ & 168 & MFCGS \\
\hline Pu-239 & $8.290 \mathrm{E}+08$ & 168 & Onsite Station \\
\hline $\mathrm{Pu}-239$ & $8.290 \mathrm{E}+08$ & 168 & Offsite Station \\
\hline $\mathrm{Sr}-90$ & $3.420 \mathrm{E}+10$ & 168 & BEA-TRA \\
\hline $\mathrm{Sr}-90$ & $3.420 \mathrm{E}+10$ & 168 & $\mathrm{BEA}-\mathrm{CPP}$ \\
\hline $\mathrm{Sr}-90$ & $3.420 \mathrm{E}+10$ & 168 & BEA-RWMC \\
\hline $\mathrm{Sr}-90$ & $3.420 \mathrm{E}+10$ & 168 & $\mathrm{BEA}-\mathrm{VAN}$ \\
\hline $\mathrm{Sr}-90$ & $3.420 \mathrm{E}+10$ & 168 & BEA-IRC \\
\hline $\mathrm{Sr}-90$ & $3.420 \mathrm{E}+10$ & 168 & BEA-BLKFT \\
\hline $\mathrm{Sr}-90$ & $3.420 \mathrm{E}+10$ & 168 & $\mathrm{BEA}-\mathrm{SMC}$ \\
\hline $\mathrm{Sr}-90$ & $3.420 \mathrm{E}+10$ & 168 & BEA-GATE \\
\hline $\mathrm{Sr}-90$ & $3.420 \mathrm{E}+10$ & 168 & BEA-REST \\
\hline $\mathrm{Sr}-90$ & $3.420 \mathrm{E}+10$ & 168 & $\mathrm{BEA}-\mathrm{IF}$ \\
\hline $\mathrm{Sr}-90$ & $3.420 \mathrm{E}+10$ & 168 & $\mathrm{BEA}-\mathrm{NRF}$ \\
\hline $\mathrm{Sr}-90$ & $3.420 \mathrm{E}+10$ & 168 & $\mathrm{BEA}-\mathrm{RTC}$ \\
\hline $\mathrm{Sr}-90$ & $3.420 \mathrm{E}+10$ & 168 & BEA-EBR \\
\hline $\mathrm{Sr}-90$ & $3.420 \mathrm{E}+10$ & 168 & BEA-MFC \\
\hline $\mathrm{Sr}-90$ & $3.420 \mathrm{E}+10$ & 168 & BEA-SUGAR \\
\hline $\mathrm{Sr}-90$ & $3.420 \mathrm{E}+10$ & 168 & BEA-INTEC \\
\hline $\mathrm{Sr}-90$ & $3.420 E+10$ & 168 & BEA-CFA \\
\hline $\mathrm{Sr}-90$ & $3.420 \mathrm{E}+10$ & 168 & BEA-EFS \\
\hline $\mathrm{Sr}-90$ & $3.420 \mathrm{E}+10$ & 168 & BEA-CRATER \\
\hline
\end{tabular}




\begin{tabular}{|c|c|c|c|c|c|}
\hline $\mathrm{Sr}-90$ & $3.420 \mathrm{E}+10$ & 168 & ESER-VAN & $9.969 \mathrm{E}-01$ & \\
\hline $\mathrm{Sr}-90$ & $3.420 \mathrm{E}+10$ & 168 & ESER-CRA & $0.000 \mathrm{E}+00$ & \\
\hline $\mathrm{Sr}-90$ & $3.420 \mathrm{E}+10$ & 168 & ESER-ARC & $3.169 \mathrm{E}-02$ & \\
\hline $\mathrm{Sr}-90$ & $3.420 \mathrm{E}+10$ & 168 & ESER-SUG & $0.000 \mathrm{E}+00$ & \\
\hline $\mathrm{Sr}-90$ & $3.420 \mathrm{E}+10$ & 168 & ESER-IDA & $1.103 \mathrm{E}-02$ & \\
\hline $\mathrm{Sr}-90$ & $3.420 \mathrm{E}+10$ & 168 & ESER-DUB & $3.427 \mathrm{E}-02$ & \\
\hline $\mathrm{Sr}-90$ & $3.420 \mathrm{E}+10$ & 168 & ESER-MON & $1.588 \mathrm{E}-01$ & \\
\hline $\mathrm{Sr}-90$ & $3.420 \mathrm{E}+10$ & 168 & ESER-EFS & $1.000 \mathrm{E}+00$ & \\
\hline $\mathrm{Sr}-90$ & $3.420 \mathrm{E}+10$ & 168 & ESER-ATO & $9.137 \mathrm{E}-01$ & \\
\hline $\mathrm{Sr}-90$ & $3.420 \mathrm{E}+10$ & 168 & ESER-MOU & $2.359 \mathrm{E}-02$ & \\
\hline $\mathrm{Sr}-90$ & $3.420 \mathrm{E}+10$ & 168 & ESER-BLU & $2.476 \mathrm{E}-02$ & \\
\hline $\operatorname{Sr}-90$ & $3.420 \mathrm{E}+10$ & 168 & ESER-TER & $4.673 \mathrm{E}-01$ & \\
\hline $\mathrm{Sr}-90$ & $3.420 \mathrm{E}+10$ & 168 & ESER-HOW & $4.958 \mathrm{E}-01$ & \\
\hline $\mathrm{Sr}-90$ & $3.420 \mathrm{E}+10$ & 168 & RWMCS & $9.642 \mathrm{E}-01$ & \\
\hline $\mathrm{Sr}-90$ & $3.420 \mathrm{E}+10$ & 168 & $\mathrm{MFCN}$ & $7.817 \mathrm{E}-01$ & \\
\hline $\mathrm{Sr}-90$ & $3.420 \mathrm{E}+10$ & 168 & MFCGS & $7.669 \mathrm{E}-01$ & \\
\hline $\mathrm{Sr}-90$ & $3.420 \mathrm{E}+10$ & 168 & Onsite_station & $1.000 \mathrm{E}+00$ & $5.684 \mathrm{E}-01$ \\
\hline $\mathrm{Sr}-90$ & $3.420 \mathrm{E}+10$ & 168 & Offsite Station & $0.000 \mathrm{E}+00$ & $0.000 \mathrm{E}+00$ \\
\hline$I-131$ & $2.280 \mathrm{E}+11$ & 168 & $\mathrm{BEA}-\mathrm{TRA}^{-}$ & $9.979 \mathrm{E}-01$ & \\
\hline$I-131$ & $2.280 \mathrm{E}+11$ & 168 & $\mathrm{BEA}-\mathrm{CPP}$ & $1.000 \mathrm{E}+00$ & \\
\hline$I-131$ & $2.280 \mathrm{E}+11$ & 168 & BEA-RWMC & $9.883 \mathrm{E}-01$ & \\
\hline$I-131$ & $2.280 E+11$ & 168 & BEA-VAN & $9.973 \mathrm{E}-01$ & \\
\hline I-131 & $2.280 \mathrm{E}+11$ & 168 & $B E A-I R C$ & $3.318 \mathrm{E}-01$ & \\
\hline$I-131$ & $2.280 \mathrm{E}+11$ & 168 & BEA-BLKFT & $4.771 \mathrm{E}-01$ & \\
\hline$I-131$ & $2.280 \mathrm{E}+11$ & 168 & $\mathrm{BEA}-\mathrm{SMC}$ & $9.831 \mathrm{E}-01$ & \\
\hline$I-131$ & $2.280 \mathrm{E}+11$ & 168 & $\mathrm{BEA}-\mathrm{GATE}$ & $1.000 \mathrm{E}+00$ & \\
\hline I-131 & $2.280 \mathrm{E}+11$ & 168 & BEA-REST & $9.971 \mathrm{E}-01$ & \\
\hline$I-131$ & $2.280 \mathrm{E}+11$ & 168 & $\mathrm{BEA}-\mathrm{IF}$ & $3.628 \mathrm{E}-01$ & \\
\hline I-131 & $2.280 \mathrm{E}+11$ & 168 & BEA-NRF & $1.000 \mathrm{E}+00$ & \\
\hline$I-131$ & $2.280 \mathrm{E}+11$ & 168 & BEA-RTC & $9.979 \mathrm{E}-01$ & \\
\hline$I-131$ & $2.280 \mathrm{E}+11$ & 168 & BEA-EBR & $9.885 \mathrm{E}-01$ & \\
\hline$I-131$ & $2.280 \mathrm{E}+11$ & 168 & $\mathrm{BEA}-\mathrm{MFC}$ & $9.804 \mathrm{E}-01$ & \\
\hline I-131 & $2.280 \mathrm{E}+11$ & 168 & BEA-SUGAR & $2.301 \mathrm{E}-01$ & \\
\hline$I-131$ & $2.280 \mathrm{E}+11$ & 168 & BEA-INTEC & $1.000 \mathrm{E}+00$ & \\
\hline$I-131$ & $2.280 \mathrm{E}+11$ & 168 & $\mathrm{BEA}-\mathrm{CFA}$ & $1.000 \mathrm{E}+00$ & \\
\hline$I-131$ & $2.280 \mathrm{E}+11$ & 168 & BEA-EFS & $1.000 \mathrm{E}+00$ & \\
\hline$I-131$ & $2.280 \mathrm{E}+11$ & 168 & BEA-CRATER & $2.727 \mathrm{E}-01$ & \\
\hline I-131 & $2.280 \mathrm{E}+11$ & 168 & ESER-VAN & $9.973 \mathrm{E}-01$ & \\
\hline$I-131$ & $2.280 \mathrm{E}+11$ & 168 & ESER-CRA & $2.730 \mathrm{E}-01$ & \\
\hline$I-131$ & $2.280 \mathrm{E}+11$ & 168 & ESER-ARC & $5.362 \mathrm{E}-01$ & \\
\hline $\mathrm{I}-131$ & $2.280 \mathrm{E}+11$ & 168 & ESER-SUG & $2.301 \mathrm{E}-01$ & \\
\hline$I-131$ & $2.280 \mathrm{E}+11$ & 168 & ESER-IDA & $3.629 \mathrm{E}-01$ & \\
\hline$I-131$ & $2.280 \mathrm{E}+11$ & 168 & ESER-DUB & $6.538 \mathrm{E}-01$ & \\
\hline I-131 & $2.280 \mathrm{E}+11$ & 168 & ESER-MON & $8.783 \mathrm{E}-01$ & \\
\hline$I-131$ & $2.280 \mathrm{E}+11$ & 168 & ESER-EFS & $1.000 \mathrm{E}+00$ & \\
\hline$I-131$ & $2.280 \mathrm{E}+11$ & 168 & ESER-ATO & $9.927 \mathrm{E}-01$ & \\
\hline I-131 & $2.280 \mathrm{E}+11$ & 168 & ESER-MOU & $4.769 \mathrm{E}-01$ & \\
\hline$I-131$ & $2.280 \mathrm{E}+11$ & 168 & ESER-BLU & $5.349 \mathrm{E}-01$ & \\
\hline$I-131$ & $2.280 \mathrm{E}+11$ & 168 & ESER-TER & $9.580 \mathrm{E}-01$ & \\
\hline$I-131$ & $2.280 \mathrm{E}+11$ & 168 & ESER-HOW & $9.309 \mathrm{E}-01$ & \\
\hline$I-131$ & $2.280 \mathrm{E}+11$ & 168 & RWMCS & $9.883 \mathrm{E}-01$ & \\
\hline$I-131$ & $2.280 \mathrm{E}+11$ & 168 & $\mathrm{MFCN}$ & $9.850 \mathrm{E}-01$ & \\
\hline$I-131$ & $2.280 \mathrm{E}+11$ & 168 & MFCGS & $9.766 \mathrm{E}-01$ & \\
\hline I-131 & $2.280 \mathrm{E}+11$ & 168 & Onsite Station & $1.000 \mathrm{E}+00$ & $7.823 \mathrm{E}-01$ \\
\hline$I-131$ & $2.280 \mathrm{E}+11$ & 168 & Offsite Station & $0.000 \mathrm{E}+00$ & $0.000 \mathrm{E}+00$ \\
\hline
\end{tabular}

RESIDENT SCENARIO, EXISTING NETWORK, OPTIMIZED FOR MFC-764

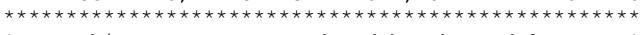

This output was produced by the model:

FREQD

FREQuency of Detection program for INL sources and air monitoring network. Version date (yyyymmdd): 20141120

Arthur S. Rood

K-Spar Inc. 4835 W Foxtrail Lane

Idaho Falls, ID 83402

asrekspar.com



Input File: freqd.par

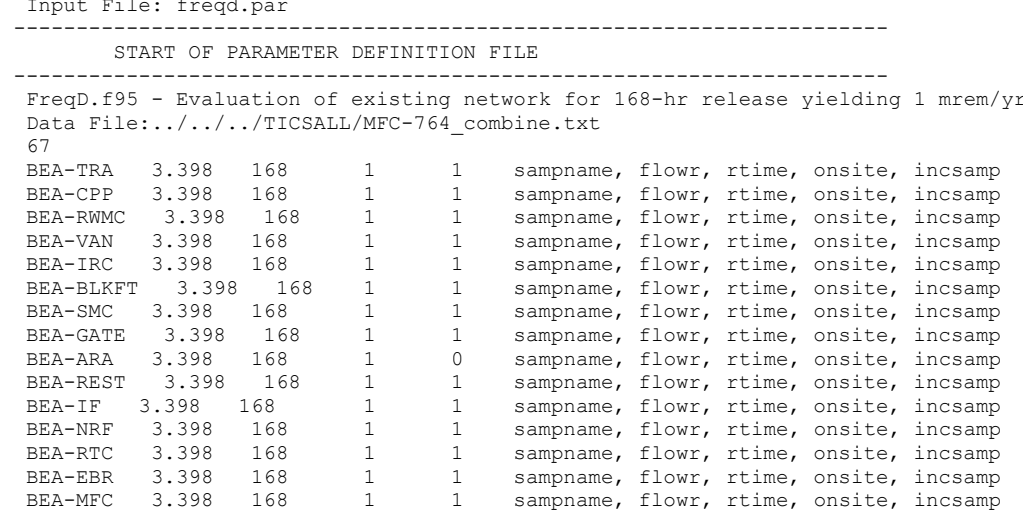




$\begin{array}{llcl}\text { BEA-SUGAR } & 3.398 & 168 & 1 \\ \text { BEA-PBF } & 3.398 & 168 & 1 \\ \text { BEA-INTEC } & 3.398 & 168 & 1 \\ \text { BEA-CFA } & 3.398 & 168 & 1 \\ \text { BEA-EFS } & 3.398 & 168 & 1 \\ \text { BEA-CRATER } & 3.398 & 168 & 1 \\ \text { ESER-VAN } & 3.398 & 168 & 1 \\ \text { ESER-CRA } & 3.398 & 168 & 1 \\ \text { ESER-ARC } & 3.398 & 168 & 1 \\ \text { ESER-SUG } & 3.398 & 168 & 1 \\ \text { ESER-IDA } & 3.398 & 168 & 1 \\ \text { ESER-DUB } & 3.398 & 168 & 1 \\ \text { ESER-MON } & 3.398 & 168 & 1 \\ \text { ESER-FAA } & 3.398 & 168 & 1 \\ \text { ESER-MAI } & 3.398 & 168 & 1 \\ \text { ESER-EFS } & 3.398 & 168 & 1 \\ \text { ESER-ATO } & 3.398 & 168 & 1 \\ \text { ESER-MOU } & 3.398 & 168 & 1 \\ \text { ESER-BLU } & 3.398 & 168 & 1 \\ \text { ESER-TER } & 3.398 & 168 & 1 \\ \text { ESER-HOW } & 3.398 & 168 & 1 \\ \text { MEI01 } & 3.398 & 168 & 1 \\ \text { MEI02 } & 3.398 & 168 & 1 \\ \text { MEI03 } & 3.398 & 168 & 1 \\ \text { MEI04 } & 3.398 & 168 & 1 \\ \text { MEI05 } & 3.398 & 168 & 1 \\ \text { MEI06 } & 3.398 & 168 & 1 \\ \text { MEI07 } & 3.398 & 168 & 1 \\ \text { MEI08 } & 3.398 & 168 & 1 \\ \text { MEI09 } & 3.398 & 168 & 1 \\ \text { MEI10 } & 3.398 & 168 & 1 \\ \text { MEI11 } & 3.398 & 168 & 1 \\ \text { MEI12 } & 3.398 & 168 & 1 \\ \text { MEI13 } & 3.398 & 168 & 1 \\ \text { MEI14 } & 3.398 & 168 & 1 \\ \text { MEI15 } & 3.398 & 168 & 1 \\ \text { MEI16 } & 3.398 & 168 & 1 \\ \text { MEI17 } & 3.398 & 168 & 1 \\ \text { MEI18 } & 3.398 & 168 & 1 \\ \text { MEI19 } & 3.398 & 168 & 1 \\ \text { MEI20 } & 3.398 & 168 & 1 \\ \text { MEI21 } & 3.398 & 168 & 1 \\ \text { MEI22 } & 3.398 & 168 & 1 \\ \text { MEI23 } & 3.398 & 168 & 1 \\ \text { MEI24 } & 3.398 & 168 & 1 \\ \text { MEI25 } & 3.398 & 168 & 1 \\ \text { MEI26 } & 3.398 & 168 & 1 \\ \text { MEI27 } & 3.398 & 168 & 1 \\ \text { RWMCS } & 3.398 & 168 & 1 \\ \text { MFCN } & 3.398 & 168 & 1 \\ \text { MFCS } & 3.398 & 168 & 1 \\ \text { MFCGS } & 3.398 & 168 & 1\end{array}$

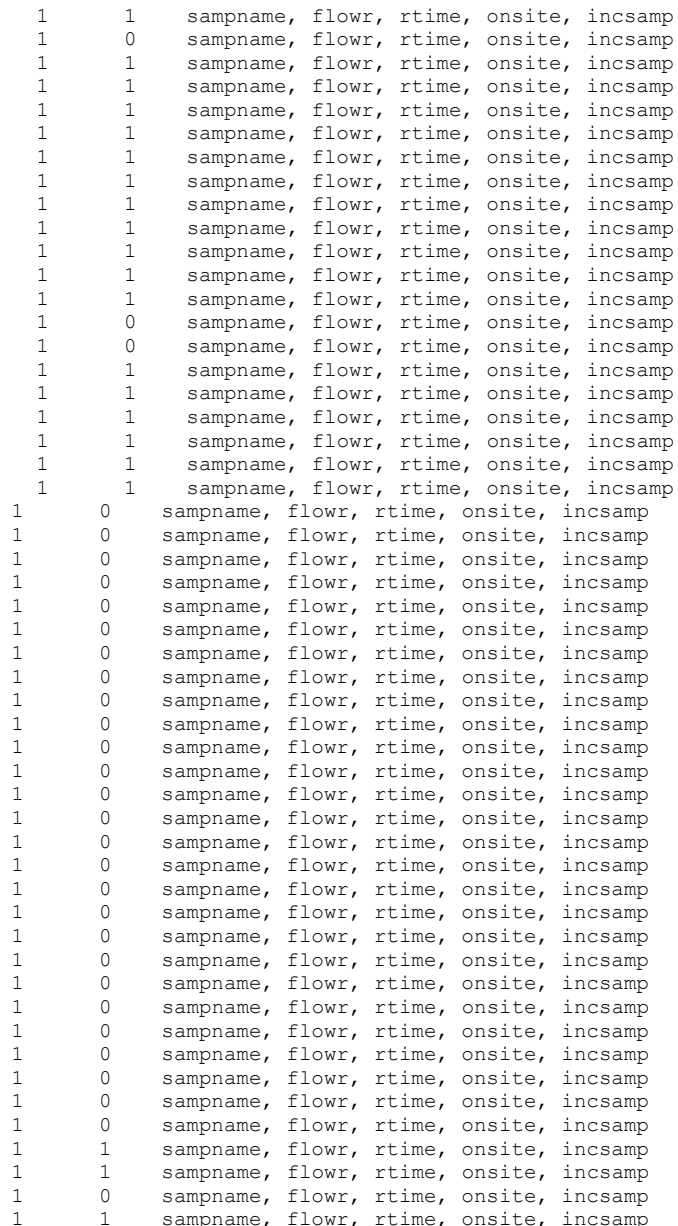
6 'pCi' 0.917 nrad units, inh $(\mathrm{m} 3 / \mathrm{hr})$

Am-241 $0.0293 .63 e-1 \quad 3.229 \mathrm{e}+09 \quad 0.0$ name, MDA, DCF(mrem/pCi), qs def for Am-241 Sol Class F, ref person DOE-1196 in DOE-11485 Table $6-5$

Pu-238 $0.0224 .07 e-1 \quad 2.875 e+09 \quad 0.0$ name, MDA, DCF (mrem/pCi), qs dcf for Pu-238 Sol Class F, ref person DOE 1196 Pu-239 $0.0224 .48 \mathrm{e}-1 \quad 2.614 \mathrm{e}+09 \quad 0.0$ name, MDA, DCF(mrem/pCi), qs dcf for Pu-239 Sol Class F, ref person DOE 1196 Sr-90 $0.2155 .88 \mathrm{e}-3 \quad 1.078 \mathrm{e}+11 \quad 0.0$ name, MDA, DCF(mrem/pCi), qs dcf for Sr-90 backcalculated from CAP88 as given in DOE-11485 Table 6-5

I-131 $0.1892 .23 e-3 \quad 7.187 e+11 \quad 8.03$ name, MDA, DCF(mrem/pCi), qs dcf for I-131 backcalculated from CAP88 as given in DOE-11485 Table 6-5 MDA backcalculated from ESER 1st Qrt 2013 report Table B1

168 'NONE'

End of Parameter Definition File

Total number of hours in data file:

Frequecy of Dection

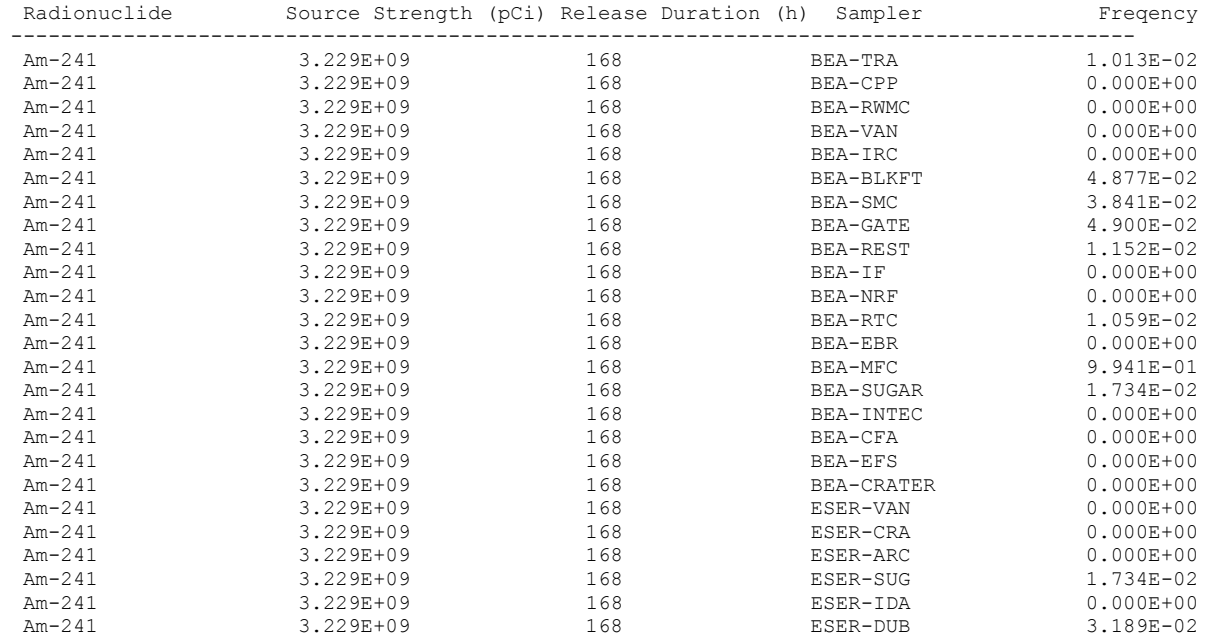




\begin{tabular}{|c|c|c|c|}
\hline Am-241 & $3.229 \mathrm{E}+09$ & 168 & ESER-MON \\
\hline$A m-241$ & $3.229 \mathrm{E}+09$ & 168 & ESER-EFS \\
\hline Am-241 & $3.229 \mathrm{E}+09$ & 168 & ESER-ATO \\
\hline$A m-241$ & $3.229 \mathrm{E}+09$ & 168 & ESER-MOU \\
\hline$A m-241$ & $3.229 \mathrm{E}+09$ & 168 & ESER-BLU \\
\hline$A m-241$ & $3.229 \mathrm{E}+09$ & 168 & ESER-TER \\
\hline $\mathrm{Am}-241$ & $3.229 \mathrm{E}+09$ & 168 & ESER-HOW \\
\hline $\mathrm{Am}-241$ & $3.229 \mathrm{E}+09$ & 168 & RWMCS \\
\hline$A m-241$ & $3.229 \mathrm{E}+09$ & 168 & $\mathrm{MFCN}$ \\
\hline$A m-241$ & $3.229 \mathrm{E}+09$ & 168 & MFCGS \\
\hline Am-241 & $3.229 \mathrm{E}+09$ & 168 & Onsite_Station \\
\hline Am-241 & $3.229 \mathrm{E}+09$ & 168 & offsité_Station \\
\hline Cs -137 & $2.814 \mathrm{E}+11$ & 168 & $\mathrm{BEA}-\mathrm{TRA}{ }^{-}$ \\
\hline Cs -137 & $2.814 \mathrm{E}+11$ & 168 & $\mathrm{BEA}-\mathrm{CPP}$ \\
\hline Cs -137 & $2.814 \mathrm{E}+11$ & 168 & BEA-RWMC \\
\hline Cs -137 & $2.814 \mathrm{E}+11$ & 168 & BEA-VAN \\
\hline Cs -137 & $2.814 \mathrm{E}+11$ & 168 & $\mathrm{BEA}-\mathrm{IRC}$ \\
\hline Cs -137 & $2.814 \mathrm{E}+11$ & 168 & BEA-BLKFT \\
\hline Cs -137 & $2.814 \mathrm{E}+11$ & 168 & $\mathrm{BEA}-\mathrm{SMC}$ \\
\hline Cs -137 & $2.814 \mathrm{E}+11$ & 168 & BEA-GATE \\
\hline Cs -137 & $2.814 \mathrm{E}+11$ & 168 & BEA-REST \\
\hline Cs -137 & $2.814 \mathrm{E}+11$ & 168 & $\mathrm{BEA}-\mathrm{IF}$ \\
\hline Cs -137 & $2.814 \mathrm{E}+11$ & 168 & $\mathrm{BEA}-\mathrm{NRF}$ \\
\hline Cs -137 & $2.814 \mathrm{E}+11$ & 168 & $\mathrm{BEA}-\mathrm{RTC}$ \\
\hline Cs -137 & $2.814 \mathrm{E}+11$ & 168 & $\mathrm{BEA}-\mathrm{EBR}$ \\
\hline Cs -137 & $2.814 \mathrm{E}+11$ & 168 & $\mathrm{BEA}-\mathrm{MFC}$ \\
\hline $\mathrm{Cs}-137$ & $2.814 \mathrm{E}+11$ & 168 & BEA-SUGAR \\
\hline Cs -137 & $2.814 \mathrm{E}+11$ & 168 & BEA-INTEC \\
\hline Cs -137 & $2.814 \mathrm{E}+11$ & 168 & $\mathrm{BEA}-\mathrm{CFA}$ \\
\hline Cs -137 & $2.814 \mathrm{E}+11$ & 168 & BEA-EFS \\
\hline Cs -137 & $2.814 \mathrm{E}+11$ & 168 & BEA-CRATER \\
\hline Cs -137 & $2.814 \mathrm{E}+11$ & 168 & ESER-VAN \\
\hline Cs -137 & $2.814 \mathrm{E}+11$ & 168 & ESER-CRA \\
\hline $\mathrm{Cs}-137$ & $2.814 \mathrm{E}+11$ & 168 & ESER-ARC \\
\hline Cs -137 & $2.814 \mathrm{E}+11$ & 168 & ESER-SUG \\
\hline Cs -137 & $2.814 \mathrm{E}+11$ & 168 & ESER-IDA \\
\hline Cs -137 & $2.814 \mathrm{E}+11$ & 168 & ESER-DUB \\
\hline $\mathrm{Cs}-137$ & $2.814 \mathrm{E}+11$ & 168 & ESER-MON \\
\hline $\mathrm{Cs}-137$ & $2.814 \mathrm{E}+11$ & 168 & ESER-EFS \\
\hline $\mathrm{Cs}-137$ & $2.814 \mathrm{E}+11$ & 168 & ESER-ATO \\
\hline Cs -137 & $2.814 \mathrm{E}+11$ & 168 & ESER-MOU \\
\hline Cs -137 & $2.814 \mathrm{E}+11$ & 168 & ESER-BLU \\
\hline $\mathrm{Cs}-137$ & $2.814 \mathrm{E}+11$ & 168 & ESER-TER \\
\hline $\mathrm{Cs}-137$ & $2.814 \mathrm{E}+11$ & 168 & ESER-HOW \\
\hline Cs -137 & $2.814 \mathrm{E}+11$ & 168 & RWMCS \\
\hline Cs -137 & $2.814 \mathrm{E}+11$ & 168 & $\mathrm{MFCN}$ \\
\hline $\mathrm{Cs}-137$ & $2.814 \mathrm{E}+11$ & 168 & MFCGS \\
\hline $\mathrm{Cs}-137$ & $2.814 \mathrm{E}+11$ & 168 & Onsite Station \\
\hline Cs -137 & $2.814 \mathrm{E}+11$ & 168 & Offsité_Station \\
\hline Pu-238 & $2.875 E+09$ & 168 & $\mathrm{BEA}-\mathrm{TRA}^{-}$ \\
\hline $\mathrm{Pu}-238$ & $2.875 \mathrm{E}+09$ & 168 & $\mathrm{BEA}-\mathrm{CPP}$ \\
\hline Pu-238 & $2.875 E+09$ & 168 & BEA-RWMC \\
\hline Pu-238 & $2.875 E+09$ & 168 & BEA-VAN \\
\hline $\mathrm{Pu}-238$ & $2.875 E+09$ & 168 & $\mathrm{BEA}-\mathrm{IRC}$ \\
\hline Pu-238 & $2.875 E+09$ & 168 & BEA-BLKFT \\
\hline Pu-238 & $2.875 \mathrm{E}+09$ & 168 & BEA-SMC \\
\hline $\mathrm{Pu}-238$ & $2.875 E+09$ & 168 & BEA-GATE \\
\hline Pu-238 & $2.875 E+09$ & 168 & BEA-REST \\
\hline Pu-238 & $2.875 E+09$ & 168 & $\mathrm{BEA}-\mathrm{IF}$ \\
\hline $\mathrm{Pu}-238$ & $2.875 E+09$ & 168 & $\mathrm{BEA}-\mathrm{NRF}$ \\
\hline $\mathrm{Pu}-238$ & $2.875 E+09$ & 168 & $\mathrm{BEA}-\mathrm{RTC}$ \\
\hline Pu-238 & $2.875 \mathrm{E}+09$ & 168 & $\mathrm{BEA}-\mathrm{EBR}$ \\
\hline Pu-238 & $2.875 E+09$ & 168 & $\mathrm{BEA}-\mathrm{MFC}$ \\
\hline Pu-238 & $2.875 \mathrm{E}+09$ & 168 & BEA-SUGAR \\
\hline Pu-238 & $2.875 \mathrm{E}+09$ & 168 & BEA-INTEC \\
\hline Pu-238 & $2.875 \mathrm{E}+09$ & 168 & $\mathrm{BEA}-\mathrm{CFA}$ \\
\hline $\mathrm{Pu}-238$ & $2.875 \mathrm{E}+09$ & 168 & BEA-EFS \\
\hline $\mathrm{Pu}-238$ & $2.875 \mathrm{E}+09$ & 168 & BEA-CRATER \\
\hline Pu-238 & $2.875 \mathrm{E}+09$ & 168 & ESER-VAN \\
\hline $\mathrm{Pu}-238$ & $2.875 E+09$ & 168 & ESER-CRA \\
\hline Pu-238 & $2.875 E+09$ & 168 & ESER-ARC \\
\hline Pu-238 & $2.875 E+09$ & 168 & ESER-SUG \\
\hline $\mathrm{Pu}-238$ & $2.875 E+09$ & 168 & ESER-IDA \\
\hline $\mathrm{Pu}-238$ & $2.875 E+09$ & 168 & ESER-DUB \\
\hline $\mathrm{Pu}-238$ & $2.875 E+09$ & 168 & ESER-MON \\
\hline $\mathrm{Pu}-238$ & $2.875 \mathrm{E}+09$ & 168 & ESER-EFS \\
\hline Pu-238 & $2.875 E+09$ & 168 & ESER-ATO \\
\hline $\mathrm{Pu}-238$ & $2.875 \mathrm{E}+09$ & 168 & ESER-MOU \\
\hline $\mathrm{Pu}-238$ & $2.875 E+09$ & 168 & ESER-BLU \\
\hline Pu-238 & $2.875 E+09$ & 168 & ESER-TER \\
\hline $\mathrm{Pu}-238$ & $2.875 E+09$ & 168 & ESER-HOW \\
\hline $\mathrm{Pu}-238$ & $2.875 \mathrm{E}+09$ & 168 & RWMCS \\
\hline $\mathrm{Pu}-238$ & $2.875 E+09$ & 168 & $\mathrm{MFCN}$ \\
\hline Pu-238 & $2.875 \mathrm{E}+09$ & 168 & MFCGS \\
\hline $\mathrm{Pu}-238$ & $2.875 \mathrm{E}+09$ & 168 & Onsite_station \\
\hline $\mathrm{Pu}-238$ & $2.875 \mathrm{E}+09$ & 168 & Offsitē_Station \\
\hline $\mathrm{Pu}-239$ & $2.614 \mathrm{E}+09$ & 168 & BEA-TRA \\
\hline $\mathrm{Pu}-239$ & $2.614 \mathrm{E}+09$ & 168 & $\mathrm{BEA}-\mathrm{CPP}$ \\
\hline $\mathrm{Pu}-239$ & $2.614 \mathrm{E}+09$ & 168 & BEA-RWMC \\
\hline $\mathrm{Pu}-239$ & $2.614 \mathrm{E}+09$ & 168 & BEA-VAN \\
\hline $\mathrm{Pu}-239$ & $2.614 \mathrm{E}+09$ & 168 & $\mathrm{BEA}-\mathrm{IRC}$ \\
\hline $\mathrm{Pu}-239$ & $2.614 \mathrm{E}+09$ & 168 & BEA-BLKFT \\
\hline $\mathrm{Pu}-239$ & $2.614 \mathrm{E}+09$ & 168 & $\mathrm{BEA}-\mathrm{SMC}$ \\
\hline $\mathrm{Pu}-239$ & $2.614 \mathrm{E}+09$ & 168 & BEA-GATE \\
\hline Pu-239 & $2.614 \mathrm{E}+09$ & 168 & BEA-REST \\
\hline
\end{tabular}




\begin{tabular}{|c|c|c|c|}
\hline Pu-239 & $2.614 \mathrm{E}+09$ & 168 & $\mathrm{BEA}-\mathrm{IF}$ \\
\hline Pu-239 & $2.614 \mathrm{E}+09$ & 168 & $\mathrm{BEA}-\mathrm{NRF}$ \\
\hline Pu-239 & $2.614 \mathrm{E}+09$ & 168 & $\mathrm{BEA}-\mathrm{RTC}$ \\
\hline Pu-239 & $2.614 \mathrm{E}+09$ & 168 & $\mathrm{BEA}-\mathrm{EBR}$ \\
\hline Pu-239 & $2.614 \mathrm{E}+09$ & 168 & BEA-MFC \\
\hline Pu-239 & $2.614 \mathrm{E}+09$ & 168 & BEA-SUGAR \\
\hline Pu-239 & $2.614 \mathrm{E}+09$ & 168 & BEA-INTEC \\
\hline Pu-239 & $2.614 \mathrm{E}+09$ & 168 & $\mathrm{BEA}-\mathrm{CFA}$ \\
\hline Pu-239 & $2.614 \mathrm{E}+09$ & 168 & BEA-EFS \\
\hline Pu-239 & $2.614 \mathrm{E}+09$ & 168 & BEA-CRATER \\
\hline Pu-239 & $2.614 \mathrm{E}+09$ & 168 & ESER-VAN \\
\hline Pu-239 & $2.614 \mathrm{E}+09$ & 168 & ESER-CRA \\
\hline Pu-239 & $2.614 \mathrm{E}+09$ & 168 & ESER-ARC \\
\hline Pu-239 & $2.614 \mathrm{E}+09$ & 168 & ESER-SUG \\
\hline Pu-239 & $2.614 \mathrm{E}+09$ & 168 & ESER-IDA \\
\hline Pu-239 & $2.614 \mathrm{E}+09$ & 168 & ESER-DUB \\
\hline Pu-239 & $2.614 \mathrm{E}+09$ & 168 & ESER-MON \\
\hline Pu-239 & $2.614 \mathrm{E}+09$ & 168 & ESER-EFS \\
\hline Pu-239 & $2.614 \mathrm{E}+09$ & 168 & ESER-ATO \\
\hline Pu-239 & $2.614 \mathrm{E}+09$ & 168 & ESER-MOU \\
\hline Pu-239 & $2.614 \mathrm{E}+09$ & 168 & ESER-BLU \\
\hline Pu-239 & $2.614 \mathrm{E}+09$ & 168 & ESER-TER \\
\hline Pu-239 & $2.614 \mathrm{E}+09$ & 168 & ESER-HOW \\
\hline Pu-239 & $2.614 \mathrm{E}+09$ & 168 & RWMCS \\
\hline Pu-239 & $2.614 \mathrm{E}+09$ & 168 & $\mathrm{MFCN}$ \\
\hline Pu-239 & $2.614 \mathrm{E}+09$ & 168 & MFCGS \\
\hline Pu-239 & $2.614 \mathrm{E}+09$ & 168 & Onsite_Station \\
\hline Pu-239 & $2.614 \mathrm{E}+09$ & 168 & Offsitē_Station \\
\hline $\mathrm{Sr}-90$ & $1.078 \mathrm{E}+11$ & 168 & BEA-TRA \\
\hline Sr -90 & $1.078 \mathrm{E}+11$ & 168 & $\mathrm{BEA}-\mathrm{CPP}$ \\
\hline Sr -90 & $1.078 \mathrm{E}+11$ & 168 & BEA-RWMC \\
\hline Sr -90 & $1.078 \mathrm{E}+11$ & 168 & BEA-VAN \\
\hline $\mathrm{Sr}-90$ & $1.078 \mathrm{E}+11$ & 168 & $\mathrm{BEA}-\mathrm{IRC}$ \\
\hline $\mathrm{Sr}-90$ & $1.078 \mathrm{E}+11$ & 168 & BEA-BLKFT \\
\hline $\mathrm{Sr}-90$ & $1.078 \mathrm{E}+11$ & 168 & BEA-SMC \\
\hline Sr -90 & $1.078 \mathrm{E}+11$ & 168 & BEA-GATE \\
\hline $\mathrm{Sr}-90$ & $1.078 \mathrm{E}+11$ & 168 & BEA-REST \\
\hline $\mathrm{Sr}-90$ & $1.078 \mathrm{E}+11$ & 168 & $\mathrm{BEA}-\mathrm{IF}$ \\
\hline $\mathrm{Sr}-90$ & $1.078 \mathrm{E}+11$ & 168 & $\mathrm{BEA}-\mathrm{NRF}$ \\
\hline Sr -90 & $1.078 \mathrm{E}+11$ & 168 & BEA-RTC \\
\hline Sr -90 & $1.078 \mathrm{E}+11$ & 168 & $\mathrm{BEA}-\mathrm{EBR}$ \\
\hline $\mathrm{Sr}-90$ & $1.078 \mathrm{E}+11$ & 168 & $\mathrm{BEA}-\mathrm{MFC}$ \\
\hline Sr -90 & $1.078 \mathrm{E}+11$ & 168 & BEA-SUGAR \\
\hline Sr -90 & $1.078 \mathrm{E}+11$ & 168 & BEA-INTEC \\
\hline Sr -90 & $1.078 \mathrm{E}+11$ & 168 & $\mathrm{BEA}-\mathrm{CFA}$ \\
\hline Sr -90 & $1.078 \mathrm{E}+11$ & 168 & BEA-EFS \\
\hline $\mathrm{Sr}-90$ & $1.078 \mathrm{E}+11$ & 168 & BEA-CRATER \\
\hline Sr -90 & $1.078 \mathrm{E}+11$ & 168 & ESER-VAN \\
\hline $\mathrm{Sr}-90$ & $1.078 \mathrm{E}+11$ & 168 & ESER-CRA \\
\hline Sr -90 & $1.078 \mathrm{E}+11$ & 168 & ESER-ARC \\
\hline $\mathrm{Sr}-90$ & $1.078 \mathrm{E}+11$ & 168 & ESER-SUG \\
\hline $\mathrm{Sr}-90$ & $1.078 \mathrm{E}+11$ & 168 & ESER-IDA \\
\hline Sr -90 & $1.078 \mathrm{E}+11$ & 168 & ESER-DUB \\
\hline Sr -90 & $1.078 \mathrm{E}+11$ & 168 & ESER-MON \\
\hline $\mathrm{Sr}-90$ & $1.078 \mathrm{E}+11$ & 168 & ESER-EFS \\
\hline $\mathrm{Sr}-90$ & $1.078 \mathrm{E}+11$ & 168 & ESER-ATO \\
\hline $\mathrm{Sr}-90$ & $1.078 \mathrm{E}+11$ & 168 & ESER-MOU \\
\hline Sr -90 & $1.078 \mathrm{E}+11$ & 168 & ESER-BLU \\
\hline Sr -90 & $1.078 \mathrm{E}+11$ & 168 & ESER-TER \\
\hline Sr -90 & $1.078 \mathrm{E}+11$ & 168 & ESER-HOW \\
\hline $\mathrm{Sr}-90$ & $1.078 \mathrm{E}+11$ & 168 & RWMCS \\
\hline Sr -90 & $1.078 \mathrm{E}+11$ & 168 & $\mathrm{MFCN}$ \\
\hline Sr -90 & $1.078 \mathrm{E}+11$ & 168 & MFCGS \\
\hline $\mathrm{Sr}-90$ & $1.078 \mathrm{E}+11$ & 168 & Onsite_station \\
\hline Sr -90 & $1.078 \mathrm{E}+11$ & 168 & Offsitè_Station \\
\hline I-131 & $7.187 \mathrm{E}+11$ & 168 & BEA-TRA \\
\hline I-131 & $7.187 \mathrm{E}+11$ & 168 & $\mathrm{BEA}-\mathrm{CPP}$ \\
\hline I-131 & $7.187 \mathrm{E}+11$ & 168 & $\mathrm{BEA}-\mathrm{RWMC}$ \\
\hline$I-131$ & $7.187 \mathrm{E}+11$ & 168 & BEA-VAN \\
\hline I-131 & $7.187 \mathrm{E}+11$ & 168 & BEA-IRC \\
\hline$I-131$ & $7.187 \mathrm{E}+11$ & 168 & BEA-BLKFT \\
\hline I-131 & $7.187 \mathrm{E}+11$ & 168 & BEA-SMC \\
\hline$I-131$ & $7.187 \mathrm{E}+11$ & 168 & BEA-GATE \\
\hline$I-131$ & $7.187 \mathrm{E}+11$ & 168 & BEA-REST \\
\hline I-131 & $7.187 \mathrm{E}+11$ & 168 & $\mathrm{BEA}-\mathrm{IF}$ \\
\hline I-131 & $7.187 \mathrm{E}+11$ & 168 & BEA-NRF \\
\hline I-131 & $7.187 \mathrm{E}+11$ & 168 & BEA-RTC \\
\hline I-131 & $7.187 \mathrm{E}+11$ & 168 & $\mathrm{BEA}-\mathrm{EBR}$ \\
\hline I-131 & $7.187 \mathrm{E}+11$ & 168 & BEA-MFC \\
\hline I-131 & $7.187 \mathrm{E}+11$ & 168 & BEA-SUGAR \\
\hline I-131 & $7.187 \mathrm{E}+11$ & 168 & BEA-INTEC \\
\hline$I-131$ & $7.187 \mathrm{E}+11$ & 168 & BEA-CFA \\
\hline I-131 & $7.187 \mathrm{E}+11$ & 168 & BEA-EFS \\
\hline I-131 & $7.187 \mathrm{E}+11$ & 168 & BEA-CRATER \\
\hline I-131 & $7.187 \mathrm{E}+11$ & 168 & ESER-VAN \\
\hline I-131 & $7.187 \mathrm{E}+11$ & 168 & ESER-CRA \\
\hline$I-131$ & $7.187 \mathrm{E}+11$ & 168 & ESER-ARC \\
\hline I-131 & $7.187 \mathrm{E}+11$ & 168 & ESER-SUG \\
\hline I-131 & $7.187 \mathrm{E}+11$ & 168 & ESER-IDA \\
\hline I-131 & $7.187 \mathrm{E}+11$ & 168 & ESER-DUB \\
\hline I-131 & $7.187 \mathrm{E}+11$ & 168 & ESER-MON \\
\hline I-131 & $7.187 \mathrm{E}+11$ & 168 & ESER-EFS \\
\hline I-131 & $7.187 \mathrm{E}+11$ & 168 & ESER-ATO \\
\hline I-131 & $7.187 \mathrm{E}+11$ & 168 & ESER-MOU \\
\hline$I-131$ & $7.187 \mathrm{E}+11$ & 168 & ESER-BLU \\
\hline
\end{tabular}




$\begin{array}{lllll}\text { I-131 } & 7.187 \mathrm{E}+11 & 168 & \text { ESER-TER } & 9.817 \mathrm{E}-01 \\ \mathrm{I}-131 & 7.187 \mathrm{E}+11 & 168 & \text { ESER-HOW } & 7.247 \mathrm{E}-01 \\ \mathrm{I}-131 & 7.187 \mathrm{E}+11 & 168 & \text { RWMCS } & 8.628 \mathrm{E}-01 \\ \text { I-131 } & 7.187 \mathrm{E}+11 & 168 & \text { MFCN } & 1.000 \mathrm{E}+00 \\ \text { I-131 } & 7.187 \mathrm{E}+11 & 168 & \text { MFCGS } & 9.790 \mathrm{E}-01 \\ \text { I-131 } & 7.187 \mathrm{E}+11 & 168 & \text { Onsite_Station } & 1.000 \mathrm{E}+00 \\ \text { I-131 } & 7.187 \mathrm{E}+11 & 168 & \text { Offsite_Station } & 0.000 \mathrm{E}+00\end{array}$

RESIDENT SCENARIO, EXISTING NETWORK, OPTIMIZED FOR MFC-774

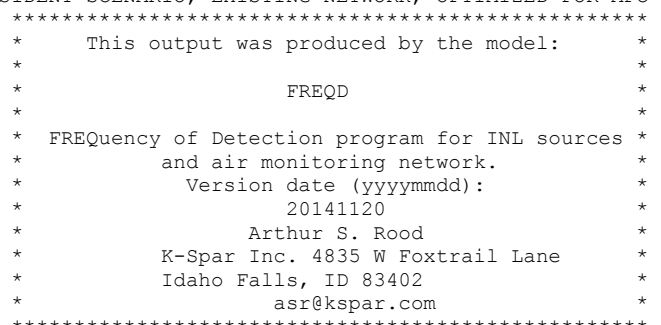

Date: 05/16/2015 Time: 21:25:49.189

Input File: freqd.par

START OF PARAMETER DEFINITION FILE

FreqD.f95 - Evaluation of existing network for 168-hr release yielding 1 mrem/yr

Data File:../././TICSALL/MFC-774_combine.txt

$\begin{array}{llll}\text { BEA-TRA } & 3.398 \quad 168\end{array}$

BEA-CPP $3.398-168$

$\begin{array}{ccc}\text { BEA-CPP } & 3.398 & 168 \\ \text { BEA-RWMC } & 3.398 & 168\end{array}$

BEA-VAN $3.398 \quad 168$

BEA-IRC $3.398 \quad 168$

BEA-BLKFT $3.398 \quad 168$

BEA-SMC $\quad 3.398 \quad 168$

BEA-GATE $\quad 3.398 \quad 168$

BEA-ARA $\quad 3.398 \quad 168$

$\begin{array}{lll}B E A-R E S T & 3.398 \quad 168\end{array}$

$\begin{array}{lll}B E A-I F & 3.398 & 168\end{array}$

$\begin{array}{lll}\text { BEA-NRF } & 3.398 & 168\end{array}$

$\begin{array}{lll}\text { BEA-RTC } & 3.398 & 168\end{array}$

BEA-EBR $\quad 3.398 \quad 168$

BEA-MFC $\quad 3.398 \quad 168$

BEA-SUGAR $3.398 \quad 168$

$\begin{array}{lll}\mathrm{BEA}-\mathrm{PBF} & 3.398 & 168\end{array}$

$\begin{array}{lll}\text { BEA-INTEC } & 3.398 & 168 \\ \text { BEA-CFA } & 3.398 & 168\end{array}$

BEA-EFS $3.398 \quad 168$

BEA-CRATER $\quad 3.398 \quad 168$

$\begin{array}{lll}\text { BEA-CRATER } & 3.398 & 168 \\ \text { ESER-VAN } & 3.398 & 168\end{array}$

$\begin{array}{lll}\text { ESER-VAN } & 3.398 & 168 \\ \text { ESER-CRA } & 3.398 & 168\end{array}$

ESER-ARC $\quad 3.398 \quad 168$

ESER-SUG $\quad 3.398 \quad 168$

$\begin{array}{lll}\text { ESER-IDA } & 3.398 & 168\end{array}$

$\begin{array}{lll}\text { ESER-DUB } & 3.398 & 168\end{array}$

$\begin{array}{lll}\text { ESER-MON } & 3.398 & 168\end{array}$

$\begin{array}{lll}\text { ESER-FAA } & 3.398 \quad 168\end{array}$

$\begin{array}{lll}\text { ESER-MAI } & 3.398 & 168\end{array}$

$\begin{array}{lll}\text { ESER-EFS } & 3.398 \quad 168\end{array}$

ESER-ATO $3.398 \quad 168$

$\begin{array}{lll}\text { ESER-MOU } & 3.398 \quad 168\end{array}$

$\begin{array}{lll}\text { ESER-BLU } & 3.398 & 168\end{array}$

ESER-TER $\quad 3.398 \quad 168$

ESER-HOW $\quad 3.398 \quad 168$

$\begin{array}{lll}\text { MEIO1 } & 3.398 \quad 168\end{array}$

$\begin{array}{lll}M E I 02 & 3.398 & 168\end{array}$

MEIO3 $3.398 \quad 168$

$\begin{array}{lll}\text { MEI04 } & 3.398 \quad 168\end{array}$

$\begin{array}{lll}\text { MEI05 } & 3.398 \quad 168\end{array}$

MEI06 $\quad 3.398 \quad 168$

$\begin{array}{lll}M E I 07 & 3.398 \quad 168\end{array}$

$3.398 \quad 168$

$\begin{array}{lll}M E 108 & 3.398 & 168\end{array}$

$\begin{array}{lll}3.398 & 168\end{array}$

$\begin{array}{lll} & 3.398 & 168\end{array}$

$\begin{array}{lll}\text { MEI11 } & 3.398 & 168 \\ \text { MEI12 } & 3.398 & 168\end{array}$

$\begin{array}{lll} & 3.398 & 168\end{array}$

$\begin{array}{lll}M E I 13 & 3.398 & 168\end{array}$

MEI14 $3.398 \quad 168$

$\begin{array}{lll}\text { MEI15 } & 3.398 \quad 168\end{array}$

$\begin{array}{lll}\text { MEI16 } & 3.398 \quad 168\end{array}$

MEI17 $\quad 3.398 \quad 168$

$\begin{array}{lll}\text { MEI18 } & 3.398 \quad 168\end{array}$

MEI19 $3.398 \quad 168$

$3.398-168$
MEI

$\begin{array}{lll}\text { MEI21 } & 3.398 & 168\end{array}$

$\begin{array}{lll}\text { MEI } 22 & 3.398 & 168\end{array}$

MEI23 $3.398 \quad 168$

MEI24 $3.398 \quad 168$

$\begin{array}{lll}\text { MEI25 } & 3.398 & 168\end{array}$

$3.398 \quad 168$

$\begin{array}{lll}\text { MEI27 } & 3.398 \quad 168\end{array}$

RWMCS $\quad 3.398 \quad 168$

sampname, flowr, rtime, onsite, incsamp sampname, flowr, rtime, onsite, incsamp sampname, flowr, rtime, onsite, incsamp sampname, flowr, rtime, onsite, incsamp sampname, flowr, rtime, onsite, incsamp sampname, flowr, rtime, onsite, incsamp sampname, flowr, rtime, onsite, incsamp sampname, flowr, rtime, onsite, incsamp sampname, flowr, rtime, onsite, incsamp samphame, flowr, rtime, onsite, incsamp sampname, flowr, rtine, onsite, incsamp samphame, flowr, rtime, onsite, lncsamp sampname, flowr, rtime, onsite, incsamp sampname, flowr, rtime, onsite, incsamp sampname, flowr, rtime, onsite, incsamp sampname, flowr, rtime, onsite, incsamp sampname, flowr, rtime, onsite, incsamp sampname, flowr, rtime, onsite, incsamp sampname, flowr, rtime, onsite, incsamp sampname, flowr, rtime, onsite, incsamp sampname, flowr, rtime, onsite, incsamp sampname, flowr, rtime, onsite, incsamp sampname, flowr, rtime, onsite, lncsamp sampnane, flowr, rtine, onsite, incsamp sampname, flowr, rtime, onsite, incsamp sampname, flowr, rtime, onsite, incsamp sampname, flowr, rtime, onsite, incsamp sampname, flowr, rtime, onsite, incsamp sampname, flowr, rtime, onsite, incsamp sampname, flowr, rtime, onsite, incsamp sampname, flowr, rtime, onsite, incsamp sampname, flowr, rtime, onsite, incsamp sampname, flowr, rtime, onsite, incsamp sampname, flowr, rtime, onsite, incsamp sampname, flowr, rtime, onsite, lncsamp sampnane, flowr, rtine, onsite, lincsamp sampname, flowr, rtime, onsite, incsamp sampname, flowr, rtime, onsite, incsamp sampname, flowr, rtime, onsite, incsamp sampname, flowr, rtime, onsite, incsamp sampname, flowr, rtime, onsite, incsamp sampname, flowr, rtime, onsite, incsamp sampname, flowr, rtime, onsite, incsamp sampname, flowr, rtime, onsite, incsamp sampname, flowr, rtime, onsite, incsamp sampname, flowr, rtime, onsite, incsamp sampname, flowr, rtime, onsite, incsamp sampname, flowr, rtime, onsite, lncsamp sampnane, flowr, rtime, onsite, incsamp sampname, llows, rtime, onsite, incsamp sampname, flowr, rtime, onsite, incsamp sampname, flowr, rtime, onsite, incsamp sampname, flowr, rtime, onsite, incsamp sampname, flowr, rtime, onsite, incsamp sampname, flowr, rtime, onsite, incsamp sampname, flowr, rtime, onsite, incsamp sampname, flowr, rtime, onsite, incsamp sampname, flowr, rtime, onsite, incsamp sampname, flowr, rtime, onsite, incsamp sampname, flowr, rtime, onsite, lncsamp sampnane, flowr, rtime, onsite, incsamp sampname, flowr, rtime, onsite, incsamp sampname, flowr, rtime, onsite, incsamp sampname, flowr, rtime, onsite, incsamp sampname, flowr, rtime, onsite, incsamp sampname, flowr, rtime, onsite, incsamp sampname, flowr, rtime, onsite, incsamp sampname, flowr, rtime, onsite, incsamp sampname, flowr, rtime, onsite, incsamp 


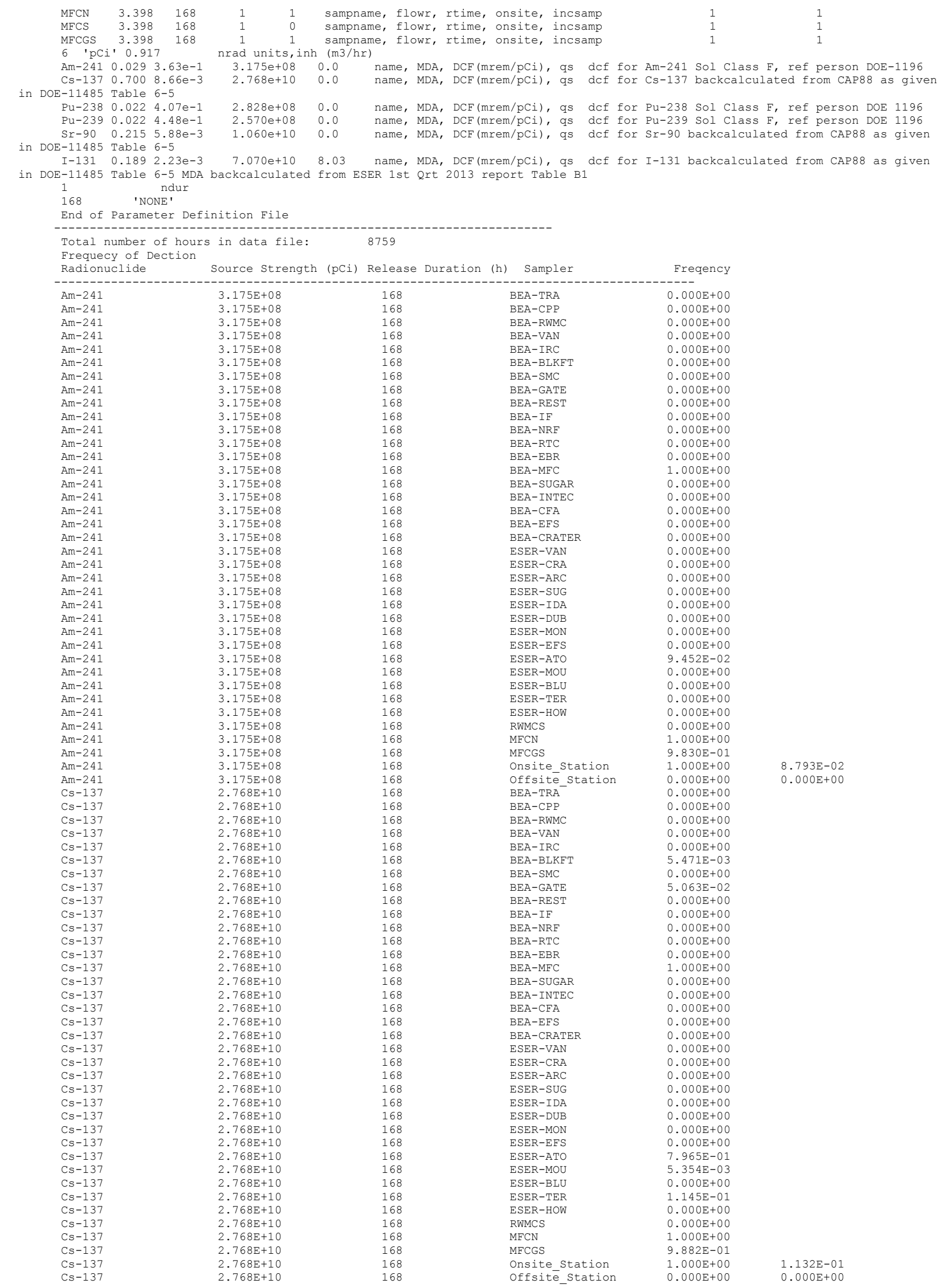




\begin{tabular}{|c|c|c|c|}
\hline $\mathrm{Pu}-238$ & $2.828 \mathrm{E}+08$ & 168 & BEA-TRA \\
\hline $\mathrm{Pu}-238$ & $2.828 \mathrm{E}+08$ & 168 & $\mathrm{BEA}-\mathrm{CPP}$ \\
\hline Pu-238 & $2.828 \mathrm{E}+08$ & 168 & BEA-RWMC \\
\hline $\mathrm{Pu}-238$ & $2.828 \mathrm{E}+08$ & 168 & BEA-VAN \\
\hline $\mathrm{Pu}-238$ & $2.828 \mathrm{E}+08$ & 168 & $\mathrm{BEA}-\mathrm{IRC}$ \\
\hline $\mathrm{Pu}-238$ & $2.828 \mathrm{E}+08$ & 168 & BEA-BLKFT \\
\hline Pu-238 & $2.828 \mathrm{E}+08$ & 168 & BEA-SMC \\
\hline $\mathrm{Pu}-238$ & $2.828 \mathrm{E}+08$ & 168 & BEA-GATE \\
\hline $\mathrm{Pu}-238$ & $2.828 \mathrm{E}+08$ & 168 & BEA-REST \\
\hline $\mathrm{Pu}-238$ & $2.828 \mathrm{E}+08$ & 168 & $\mathrm{BEA}-\mathrm{IF}$ \\
\hline $\mathrm{Pu}-238$ & $2.828 \mathrm{E}+08$ & 168 & $\mathrm{BEA}-\mathrm{NRF}$ \\
\hline $\mathrm{Pu}-238$ & $2.828 \mathrm{E}+08$ & 168 & $\mathrm{BEA}-\mathrm{RTC}$ \\
\hline $\mathrm{Pu}-238$ & $2.828 \mathrm{E}+08$ & 168 & $\mathrm{BEA}-\mathrm{EBR}$ \\
\hline $\mathrm{Pu}-238$ & $2.828 \mathrm{E}+08$ & 168 & $\mathrm{BEA}-\mathrm{MFC}$ \\
\hline $\mathrm{Pu}-238$ & $2.828 \mathrm{E}+08$ & 168 & BEA-SUGAR \\
\hline $\mathrm{Pu}-238$ & $2.828 \mathrm{E}+08$ & 168 & BEA-INTEC \\
\hline $\mathrm{Pu}-238$ & $2.828 \mathrm{E}+08$ & 168 & $\mathrm{BEA}-\mathrm{CFA}$ \\
\hline $\mathrm{Pu}-238$ & $2.828 \mathrm{E}+08$ & 168 & BEA-EFS \\
\hline $\mathrm{Pu}-238$ & $2.828 \mathrm{E}+08$ & 168 & BEA-CRATER \\
\hline $\mathrm{Pu}-238$ & $2.828 \mathrm{E}+08$ & 168 & ESER-VAN \\
\hline $\mathrm{Pu}-238$ & $2.828 \mathrm{E}+08$ & 168 & ESER-CRA \\
\hline $\mathrm{Pu}-238$ & $2.828 \mathrm{E}+08$ & 168 & ESER-ARC \\
\hline $\mathrm{Pu}-238$ & $2.828 \mathrm{E}+08$ & 168 & ESER-SUG \\
\hline $\mathrm{Pu}-238$ & $2.828 \mathrm{E}+08$ & 168 & ESER-IDA \\
\hline $\mathrm{Pu}-238$ & $2.828 \mathrm{E}+08$ & 168 & ESER-DUB \\
\hline $\mathrm{Pu}-238$ & $2.828 \mathrm{E}+08$ & 168 & ESER-MON \\
\hline $\mathrm{Pu}-238$ & $2.828 \mathrm{E}+08$ & 168 & ESER-EFS \\
\hline $\mathrm{Pu}-238$ & $2.828 \mathrm{E}+08$ & 168 & ESER-ATO \\
\hline $\mathrm{Pu}-238$ & $2.828 \mathrm{E}+08$ & 168 & ESER-MOU \\
\hline $\mathrm{Pu}-238$ & $2.828 \mathrm{E}+08$ & 168 & ESER-BLU \\
\hline $\mathrm{Pu}-238$ & $2.828 \mathrm{E}+08$ & 168 & ESER-TER \\
\hline $\mathrm{Pu}-238$ & $2.828 \mathrm{E}+08$ & 168 & ESER-HOW \\
\hline $\mathrm{Pu}-238$ & $2.828 \mathrm{E}+08$ & 168 & RWMCS \\
\hline Pu-238 & $2.828 \mathrm{E}+08$ & 168 & $\mathrm{MFCN}$ \\
\hline $\mathrm{Pu}-238$ & $2.828 \mathrm{E}+08$ & 168 & MFCGS \\
\hline $\mathrm{Pu}-238$ & $2.828 \mathrm{E}+08$ & 168 & Onsite_Station \\
\hline $\mathrm{Pu}-238$ & $2.828 \mathrm{E}+08$ & 168 & Offsitē_Station \\
\hline Pu-239 & $2.570 \mathrm{E}+08$ & 168 & $\mathrm{BEA}-\mathrm{TRA}{ }^{-}$ \\
\hline $\mathrm{Pu}-239$ & $2.570 \mathrm{E}+08$ & 168 & $\mathrm{BEA}-\mathrm{CPP}$ \\
\hline Pu-239 & $2.570 \mathrm{E}+08$ & 168 & BEA-RWMC \\
\hline $\mathrm{Pu}-239$ & $2.570 \mathrm{E}+08$ & 168 & BEA-VAN \\
\hline $\mathrm{Pu}-239$ & $2.570 \mathrm{E}+08$ & 168 & $\mathrm{BEA}-\mathrm{IRC}$ \\
\hline Pu-239 & $2.570 \mathrm{E}+08$ & 168 & BEA-BLKFT \\
\hline $\mathrm{Pu}-239$ & $2.570 \mathrm{E}+08$ & 168 & $\mathrm{BEA}-\mathrm{SMC}$ \\
\hline $\mathrm{Pu}-239$ & $2.570 \mathrm{E}+08$ & 168 & BEA-GATE \\
\hline $\mathrm{Pu}-239$ & $2.570 \mathrm{E}+08$ & 168 & BEA-REST \\
\hline Pu-239 & $2.570 \mathrm{E}+08$ & 168 & $\mathrm{BEA}-\mathrm{IF}$ \\
\hline $\mathrm{Pu}-239$ & $2.570 \mathrm{E}+08$ & 168 & $\mathrm{BEA}-\mathrm{NRF}$ \\
\hline $\mathrm{Pu}-239$ & $2.570 \mathrm{E}+08$ & 168 & BEA-RTC \\
\hline $\mathrm{Pu}-239$ & $2.570 \mathrm{E}+08$ & 168 & $\mathrm{BEA}-\mathrm{EBR}$ \\
\hline $\mathrm{Pu}-239$ & $2.570 \mathrm{E}+08$ & 168 & $\mathrm{BEA}-\mathrm{MFC}$ \\
\hline Pu-239 & $2.570 \mathrm{E}+08$ & 168 & BEA-SUGAR \\
\hline $\mathrm{Pu}-239$ & $2.570 \mathrm{E}+08$ & 168 & BEA-INTEC \\
\hline $\mathrm{Pu}-239$ & $2.570 \mathrm{E}+08$ & 168 & $\mathrm{BEA}-\mathrm{CFA}$ \\
\hline $\mathrm{Pu}-239$ & $2.570 \mathrm{E}+08$ & 168 & BEA-EFS \\
\hline $\mathrm{Pu}-239$ & $2.570 \mathrm{E}+08$ & 168 & BEA-CRATER \\
\hline $\mathrm{Pu}-239$ & $2.570 \mathrm{E}+08$ & 168 & ESER-VAN \\
\hline $\mathrm{Pu}-239$ & $2.570 \mathrm{E}+08$ & 168 & ESER-CRA \\
\hline $\mathrm{Pu}-239$ & $2.570 \mathrm{E}+08$ & 168 & ESER-ARC \\
\hline Pu-239 & $2.570 \mathrm{E}+08$ & 168 & ESER-SUG \\
\hline $\mathrm{Pu}-239$ & $2.570 \mathrm{E}+08$ & 168 & ESER-IDA \\
\hline $\mathrm{Pu}-239$ & $2.570 \mathrm{E}+08$ & 168 & ESER-DUB \\
\hline $\mathrm{Pu}-239$ & $2.570 \mathrm{E}+08$ & 168 & ESER-MON \\
\hline $\mathrm{Pu}-239$ & $2.570 \mathrm{E}+08$ & 168 & ESER-EFS \\
\hline Pu-239 & $2.570 \mathrm{E}+08$ & 168 & ESER-ATO \\
\hline $\mathrm{Pu}-239$ & $2.570 \mathrm{E}+08$ & 168 & ESER-MOU \\
\hline $\mathrm{Pu}-239$ & $2.570 \mathrm{E}+08$ & 168 & ESER-BLU \\
\hline $\mathrm{Pu}-239$ & $2.570 \mathrm{E}+08$ & 168 & ESER-TER \\
\hline $\mathrm{Pu}-239$ & $2.570 \mathrm{E}+08$ & 168 & ESER-HOW \\
\hline $\mathrm{Pu}-239$ & $2.570 \mathrm{E}+08$ & 168 & RWMCS \\
\hline $\mathrm{Pu}-239$ & $2.570 \mathrm{E}+08$ & 168 & MFCN \\
\hline $\mathrm{Pu}-239$ & $2.570 \mathrm{E}+08$ & 168 & MFCGS \\
\hline $\mathrm{Pu}-239$ & $2.570 \mathrm{E}+08$ & 168 & Onsite_station \\
\hline Pu-239 & $2.570 \mathrm{E}+08$ & 168 & offsitē_station \\
\hline $\mathrm{Sr}-90$ & $1.060 \mathrm{E}+10$ & 168 & BEA-TRA \\
\hline $\mathrm{Sr}-90$ & $1.060 \mathrm{E}+10$ & 168 & $\mathrm{BEA}-\mathrm{CPP}$ \\
\hline $\mathrm{Sr}-90$ & $1.060 \mathrm{E}+10$ & 168 & BEA-RWMC \\
\hline $\mathrm{Sr}-90$ & $1.060 \mathrm{E}+10$ & 168 & BEA-VAN \\
\hline Sr -90 & $1.060 \mathrm{E}+10$ & 168 & BEA-IRC \\
\hline $\mathrm{Sr}-90$ & $1.060 \mathrm{E}+10$ & 168 & BEA-BLKFT \\
\hline Sr -90 & $1.060 \mathrm{E}+10$ & 168 & BEA-SMC \\
\hline $\mathrm{Sr}-90$ & $1.060 \mathrm{E}+10$ & 168 & BEA-GATE \\
\hline $\mathrm{Sr}-90$ & $1.060 \mathrm{E}+10$ & 168 & BEA-REST \\
\hline Sr -90 & $1.060 \mathrm{E}+10$ & 168 & $\mathrm{BEA}-\mathrm{IF}$ \\
\hline $\operatorname{Sr}-90$ & $1.060 \mathrm{E}+10$ & 168 & $\mathrm{BEA}-\mathrm{NRF}$ \\
\hline $\mathrm{Sr}-90$ & $1.060 \mathrm{E}+10$ & 168 & BEA-RTC \\
\hline $\mathrm{Sr}-90$ & $1.060 \mathrm{E}+10$ & 168 & $\mathrm{BEA}-\mathrm{EBR}$ \\
\hline $\mathrm{Sr}-90$ & $1.060 \mathrm{E}+10$ & 168 & $\mathrm{BEA}-\mathrm{MFC}$ \\
\hline $\mathrm{Sr}-90$ & $1.060 \mathrm{E}+10$ & 168 & BEA-SUGAR \\
\hline $\operatorname{Sr}-90$ & $1.060 \mathrm{E}+10$ & 168 & BEA-INTEC \\
\hline $\mathrm{Sr}-90$ & $1.060 \mathrm{E}+10$ & 168 & $\mathrm{BEA}-\mathrm{CFA}$ \\
\hline $\mathrm{Sr}-90$ & $1.060 \mathrm{E}+10$ & 168 & BEA-EFS \\
\hline $\mathrm{Sr}-90$ & $1.060 \mathrm{E}+10$ & 168 & BEA-CRATER \\
\hline $\operatorname{Sr}-90$ & $1.060 \mathrm{E}+10$ & 168 & ESER-VAN \\
\hline $\mathrm{Sr}-90$ & $1.060 \mathrm{E}+10$ & 168 & ESER-CRA \\
\hline
\end{tabular}




\begin{tabular}{|c|c|c|c|c|c|}
\hline Sr -90 & $1.060 \mathrm{E}+10$ & 168 & ESER-ARC & $0.000 \mathrm{E}+00$ & \\
\hline Sr -90 & $1.060 \mathrm{E}+10$ & 168 & ESER-SUG & $0.000 \mathrm{E}+00$ & \\
\hline Sr -90 & $1.060 \mathrm{E}+10$ & 168 & ESER-IDA & $0.000 \mathrm{E}+00$ & \\
\hline Sr -90 & $1.060 \mathrm{E}+10$ & 168 & ESER-DUB & $0.000 \mathrm{E}+00$ & \\
\hline Sr -90 & $1.060 \mathrm{E}+10$ & 168 & ESER-MON & $0.000 \mathrm{E}+00$ & \\
\hline Sr-90 & $1.060 \mathrm{E}+10$ & 168 & ESER-EFS & $1.665 \mathrm{E}-02$ & \\
\hline Sr -90 & $1.060 \mathrm{E}+10$ & 168 & ESER-ATO & $8.390 \mathrm{E}-01$ & \\
\hline Sr -90 & $1.060 \mathrm{E}+10$ & 168 & ESER-MOU & $1.688 \mathrm{E}-02$ & \\
\hline Sr -90 & $1.060 \mathrm{E}+10$ & 168 & ESER-BLU & $0.000 \mathrm{E}+00$ & \\
\hline Sr -90 & $1.060 \mathrm{E}+10$ & 168 & ESER-TER & $2.299 \mathrm{E}-01$ & \\
\hline Sr -90 & $1.060 \mathrm{E}+10$ & 168 & ESER-HOW & $0.000 \mathrm{E}+00$ & \\
\hline Sr -90 & $1.060 \mathrm{E}+10$ & 168 & RWMCS & $0.000 \mathrm{E}+00$ & \\
\hline Sr -90 & $1.060 \mathrm{E}+10$ & 168 & $\mathrm{MFCN}$ & $1.000 \mathrm{E}+00$ & \\
\hline Sr -90 & $1.060 \mathrm{E}+10$ & 168 & MFCGS & $9.882 \mathrm{E}-01$ & \\
\hline Sr -90 & $1.060 \mathrm{E}+10$ & 168 & Onsite Station & $1.000 \mathrm{E}+00$ & $1.203 \mathrm{E}-01$ \\
\hline Sr -90 & $1.060 \mathrm{E}+10$ & 168 & Offsitē_Station & $0.000 \mathrm{E}+00$ & $0.000 \mathrm{E}+00$ \\
\hline I-131 & $7.070 \mathrm{E}+10$ & 168 & $\mathrm{BEA}-\mathrm{TRA}^{-}$ & $4.470 \mathrm{E}-01$ & \\
\hline I-131 & $7.070 \mathrm{E}+10$ & 168 & $\mathrm{BEA}-\mathrm{CPP}$ & $6.183 \mathrm{E}-01$ & \\
\hline I-131 & $7.070 \mathrm{E}+10$ & 168 & BEA-RWMC & $3.862 \mathrm{E}-01$ & \\
\hline $\mathrm{I}-131$ & $7.070 \mathrm{E}+10$ & 168 & $\mathrm{BEA}-\mathrm{VAN}$ & $5.462 \mathrm{E}-01$ & \\
\hline I-131 & $7.070 \mathrm{E}+10$ & 168 & $\mathrm{BEA}-\mathrm{IRC}$ & $1.594 \mathrm{E}-01$ & \\
\hline I-131 & $7.070 \mathrm{E}+10$ & 168 & BEA-BLKFT & $2.834 \mathrm{E}-01$ & \\
\hline I-131 & $7.070 \mathrm{E}+10$ & 168 & BEA-SMC & $4.396 \mathrm{E}-01$ & \\
\hline I-131 & $7.070 \mathrm{E}+10$ & 168 & $\mathrm{BEA}-\mathrm{GATE}$ & $6.396 \mathrm{E}-01$ & \\
\hline I-131 & $7.070 \mathrm{E}+10$ & 168 & BEA-REST & $3.820 \mathrm{E}-01$ & \\
\hline I-131 & $7.070 \mathrm{E}+10$ & 168 & $\mathrm{BEA}-\mathrm{IF}$ & $1.819 \mathrm{E}-01$ & \\
\hline I-131 & $7.070 \mathrm{E}+10$ & 168 & $\mathrm{BEA}-\mathrm{NRF}$ & $5.006 \mathrm{E}-01$ & \\
\hline I-131 & $7.070 \mathrm{E}+10$ & 168 & $\mathrm{BEA}-\mathrm{RTC}$ & $4.452 \mathrm{E}-01$ & \\
\hline I-131 & $7.070 \mathrm{E}+10$ & 168 & $\mathrm{BEA}-\mathrm{EBR}$ & $5.246 \mathrm{E}-01$ & \\
\hline I-131 & $7.070 \mathrm{E}+10$ & 168 & $\mathrm{BEA}-\mathrm{MFC}$ & $1.000 \mathrm{E}+00$ & \\
\hline $\mathrm{I}-131$ & $7.070 \mathrm{E}+10$ & 168 & BEA-SUGAR & $5.320 \mathrm{E}-02$ & \\
\hline I-131 & $7.070 \mathrm{E}+10$ & 168 & BEA-INTEC & $6.315 \mathrm{E}-01$ & \\
\hline $\mathrm{I}-131$ & $7.070 \mathrm{E}+10$ & 168 & $\mathrm{BEA}-\mathrm{CFA}$ & $7.131 \mathrm{E}-01$ & \\
\hline I-131 & $7.070 \mathrm{E}+10$ & 168 & BEA-EFS & $6.514 \mathrm{E}-01$ & \\
\hline I-131 & $7.070 \mathrm{E}+10$ & 168 & BEA-CRATER & $0.000 \mathrm{E}+00$ & \\
\hline $\mathrm{I}-131$ & $7.070 \mathrm{E}+10$ & 168 & ESER-VAN & $5.462 \mathrm{E}-01$ & \\
\hline I-131 & $7.070 \mathrm{E}+10$ & 168 & ESER-CRA & $0.000 \mathrm{E}+00$ & \\
\hline$I-131$ & $7.070 \mathrm{E}+10$ & 168 & ESER-ARC & $0.000 \mathrm{E}+00$ & \\
\hline I-131 & $7.070 \mathrm{E}+10$ & 168 & ESER-SUG & $5.320 \mathrm{E}-02$ & \\
\hline I-131 & $7.070 \mathrm{E}+10$ & 168 & ESER-IDA & $1.819 \mathrm{E}-01$ & \\
\hline I-131 & $7.070 \mathrm{E}+10$ & 168 & ESER-DUB & $1.360 \mathrm{E}-01$ & \\
\hline I-131 & $7.070 \mathrm{E}+10$ & 168 & ESER-MON & $3.340 \mathrm{E}-01$ & \\
\hline$I-131$ & $7.070 \mathrm{E}+10$ & 168 & ESER-EFS & $6.515 \mathrm{E}-01$ & \\
\hline I-131 & $7.070 \mathrm{E}+10$ & 168 & ESER-ATO & $9.681 \mathrm{E}-01$ & \\
\hline I-131 & $7.070 \mathrm{E}+10$ & 168 & ESER-MOU & $2.833 \mathrm{E}-01$ & \\
\hline I-131 & $7.070 \mathrm{E}+10$ & 168 & ESER-BLU & $7.613 \mathrm{E}-02$ & \\
\hline$I-131$ & $7.070 \mathrm{E}+10$ & 168 & ESER-TER & $8.418 \mathrm{E}-01$ & \\
\hline$I-131$ & $7.070 \mathrm{E}+10$ & 168 & ESER-HOW & $1.107 \mathrm{E}-01$ & \\
\hline I-131 & $7.070 \mathrm{E}+10$ & 168 & RWMCS & $3.881 \mathrm{E}-01$ & \\
\hline$I-131$ & $7.070 \mathrm{E}+10$ & 168 & MFCN & $1.000 \mathrm{E}+00$ & \\
\hline I-131 & $7.070 \mathrm{E}+10$ & 168 & MFCGS & $1.000 \mathrm{E}+00$ & \\
\hline $\mathrm{I}-131$ & $7.070 \mathrm{E}+10$ & 168 & Onsite Station & $1.000 \mathrm{E}+00$ & $4.335 \mathrm{E}-01$ \\
\hline I-131 & $7.070 \mathrm{E}+10$ & 168 & Offsite Station & $0.000 \mathrm{E}+00$ & $0.000 \mathrm{E}+00$ \\
\hline
\end{tabular}

RESIDENT SCENARIO, EXISTING NETWORK, OPTIMIZED FOR NRF

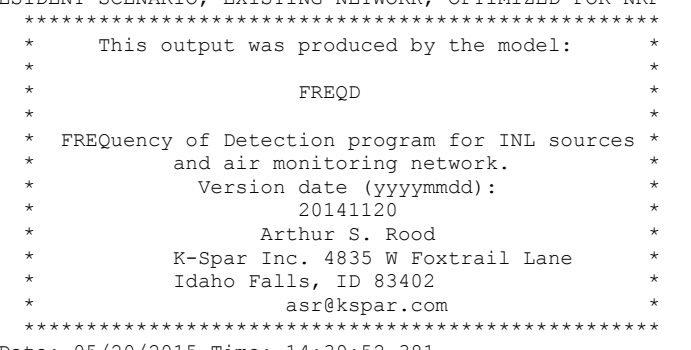

Date: 05/20/2015 Time: 14:39:52.381

Input File: freqd.par

START OF PARAMETER DEFINITION FILE

FreqD.f95 - Evaluation of existing network for 168-hr release yielding 1 mrem/yr

Data File:../.../TICSALL/NRF_combine.txt

67

\begin{tabular}{|c|c|c|c|c|c|c|c|c|c|}
\hline BEA-TRA & 3.398 & 168 & 1 & 1 & sampname, & flowr, & rtime, & onsite, & incsamp \\
\hline BEA-CPP & 3.398 & 168 & 1 & 1 & sampname, & flowr, & rtime, & onsite, & incsamp \\
\hline EA-RWMC & 3.398 & 168 & 1 & 1 & sampname, & flowr, & rtime, & onsite, & incsamp \\
\hline A-VAN & 3.398 & 168 & 1 & 1 & sampname, & flowr, & rtime, & onsite, & incsamp \\
\hline$A-I R C$ & 3.398 & 168 & 7 & 1 & sampname, & flowr, & rtime, & onsite, & incsamp \\
\hline$A-B L K F T$ & 3.398 & 168 & 1 & 1 & sampname, & flowr, & rtime, & onsite, & incsamp \\
\hline$A-S M C$ & 3.398 & 168 & 1 & 1 & sampname, & flowr, & rtime, & onsite, & incsamp \\
\hline A-GATE & 3.398 & 168 & 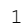 & 1 & sampname, & flowr, & rtime, & onsite, & incsamp \\
\hline$A-A R A$ & 3.398 & 168 & 1 & 0 & sampname, & flowr, & rtime, & onsite, & incsamp \\
\hline $\mathrm{EA}-\mathrm{REST}$ & 3.398 & 168 & 1 & 1 & sampname, & flowr, & rtime, & onsite, & incsamp \\
\hline $\mathrm{BEA}-\mathrm{IF}$ & 3.398 & 168 &  & 1 & sampname, & flowr, & rtime, & onsite, & incsamp \\
\hline $\mathrm{CA}-\mathrm{NRF}$ & 3.398 & 168 & 1 & 1 & sampname, & flowr, & rtime, & onsite, & incsamp \\
\hline$A-R T C$ & 3.398 & 168 & 1 & 1 & sampname, & flowr, & rtime, & onsite, & incsamp \\
\hline$B E A-E B R$ & 3.398 & 168 & 1 & 1 & sampname, & flowr, & rtime, & onsite, & incsamp \\
\hline $\mathrm{A}-\mathrm{MFC}$ & 3.398 & 168 & 1 & & sampname, & flowr, & rtime, & onsite, & incsamp \\
\hline A-SUGAR & 3.398 & 168 & 1 & 1 & sampname, & flowr, & rtime, & onsite, & incsamp \\
\hline -PBF & 3.39 & 168 & 1 & ( & sampname, & flowr, & rtime, & onsite, & incsamp \\
\hline & & & & & & & & & csamn \\
\hline
\end{tabular}




\begin{tabular}{|c|c|c|c|c|}
\hline $\mathrm{BEA}-\mathrm{CFA}$ & 3.398 & \multicolumn{2}{|c|}{168} & \\
\hline$B E A-E F S$ & 3.398 & & 68 & \\
\hline BEA-CRATER & \multicolumn{2}{|c|}{ R $\quad 3.398$} & 168 & \\
\hline ESER-VAN & \multicolumn{2}{|l|}{3.398} & 168 & \\
\hline ESER-CRA & \multicolumn{2}{|l|}{3.398} & 168 & \\
\hline ESER-ARC & \multicolumn{2}{|l|}{3.398} & 168 & \\
\hline ESER-SUG & \multicolumn{2}{|l|}{3.398} & 168 & \\
\hline ESER-IDA & \multicolumn{2}{|c|}{3.398} & 168 & \\
\hline ESER-DUB & \multicolumn{2}{|c|}{3.398} & 168 & \\
\hline ESER-MON & \multicolumn{2}{|l|}{3.398} & 168 & \\
\hline ESER-FAA & \multicolumn{2}{|l|}{3.398} & 168 & \\
\hline ESER-MAI & 3.398 & & 168 & \\
\hline ESER-EFS & 3.398 & & 168 & \\
\hline ESER-ATO & 3.398 & & 168 & \\
\hline ESER-MOU & 3.398 & & 168 & \\
\hline ESER-BLU & 3.398 & & 168 & \\
\hline ESER-TER & 3.398 & & 168 & \\
\hline ESER-HOW & 3.398 & & 168 & \\
\hline MEI01 & 3.398 & 168 & & 1 \\
\hline MEIO2 & 3.398 & 168 & & 1 \\
\hline MEI03 & 3.398 & 168 & & 1 \\
\hline MEIO 4 & 3.398 & 168 & & 1 \\
\hline MEI0 5 & 3.398 & 168 & & 1 \\
\hline MEI0 6 & 3.398 & 168 & & 1 \\
\hline MEI07 & 3.398 & 168 & & 1 \\
\hline MEI08 & 3.398 & 168 & & 1 \\
\hline MEIO9 & 3.398 & 168 & & 1 \\
\hline MEI10 & 3.398 & 168 & & 1 \\
\hline MEII1 & 3.398 & 168 & & 1 \\
\hline MEI12 & 3.398 & 168 & & 1 \\
\hline MEI13 & 3.398 & 168 & & 1 \\
\hline MEI14 & 3.398 & 168 & & 1 \\
\hline MEI15 & 3.398 & 168 & & 1 \\
\hline MEI16 & 3.398 & 168 & & 1 \\
\hline MEI17 & 3.398 & 168 & & 1 \\
\hline MEI18 & 3.398 & 168 & & 1 \\
\hline MEI19 & 3.398 & 168 & & 1 \\
\hline MEI20 & 3.398 & 168 & & 1 \\
\hline MEI21 & 3.398 & 168 & & 1 \\
\hline MEI22 & 3.398 & 168 & & 1 \\
\hline MEI 23 & 3.398 & 168 & & 1 \\
\hline MEI 24 & 3.398 & 168 & & 1 \\
\hline MEI 25 & 3.398 & 168 & & 1 \\
\hline MEI 26 & 3.398 & 168 & & 1 \\
\hline MEI27 & 3.398 & 168 & & 1 \\
\hline RWMCS & 3.398 & 168 & & 1 \\
\hline MFCN & 3.398 & 168 & & 1 \\
\hline MFCS & 3.398 & 168 & & 1 \\
\hline MFCGS & 3.398 & 168 & & 1 \\
\hline
\end{tabular}

1 sampname, flowr, rtime, onsite, incsamp
1 sampname, flowr, rtime, onsite, incsamp
1 sampname, flowr, rtime, onsite, incsamp
1 sampname, flowr, rtime, onsite, incsamp
1 sampname, flowr, rtime, onsite, incsamp
1 sampname, flowr, rtime, onsite, incsamp
1 sampname, flowr, rtime, onsite, incsamp
1 sampname, flowr, rtime, onsite, incsamp
1 sampname, flowr, rtime, onsite, incsamp
sampname, flowr, rtime, onsite, incsamp
s sampname, flowr, rtime, onsite, incsamp
1 sampname, flowr, rtime, onsite, incsamp
1 sampname, flowr, rtime, onsite, incsamp
1 sampname, flowr, rtime, onsite, incsamp
sampname, flowr, rtime, onsite, incsamp
1 sampname, flowr, rtime, onsite, incsamp
1 sampname, flowr, rtime, onsite, incsamp
sampname, flowr, rtime, onsite, incsamp
sampname, flowr, rtime, onsite, incsamp
sampname, flowr, rtime, onsite, incsamp
sampname, flowr, rtime, onsite, incsamp
sampname, flowr, rtime, onsite, incsamp
sampname, flowr, rtime, onsite, incsamp
sampname, flowr, rtime, onsite, incsamp
sampname, flowr, rtime, onsite, incsamp
sampname, flowr, rtime, onsite, incsamp
sampname, flowr, rtime, onsite, incsamp
sampname, flowr, rtime, onsite, incsamp
sampname, flowr, rtime, onsite, incsamp
sampname, flowr, rtime, onsite, incsamp
sampname, flowr, rtime, onsite, incsamp
sampname, flowr, rtime, onsite, incsamp
sampname, flowr, rtime, onsite, incsamp
sampname, flowr, rtime, onsite, incsamp
sampname, flowr, rtime, onsite, incsamp
sampname, flowr, rtime, onsite, incsamp
sampname, flowr, rtime, onsite, incsamp
sampname, flowr, rtime, onsite, incsamp
sampname, flowr, rtime, onsite, incsamp
sampname, flowr, rtime, onsite, incsamp
sampname, flowr, rtime, onsite, incsamp
sampname, flowr, rtime, onsite, incsamp
sampname, flowr, rtime, onsite, incsamp
sampname, flowr, rtime, onsite, incsamp
sampname, flowr, rtime, onsite, incsamp
sampname, flowr, rtime, onsite, incsamp
sampname, flowr, rtime, onsite, incsamp
sampname, flowr, rtime, onsite, incsamp
sampname, flowr, rtime, onsite, incsamp
6 'pCi' $0.917 \quad$ nrad units, inh $(\mathrm{m} 3 / \mathrm{hr})$

Am-241 $0.0293 .63 e-1 \quad 1.680 e+09 \quad 0.0$ name, MDA, DCF(mrem/pCi), qs dcf for Am-241 Sol Class F, ref person DoE-1196 Cs-137 $0.7008 .66 \mathrm{e}-3 \quad 1.465 \mathrm{e}+11 \quad 0.0$ name, MDA, DCF (mrem/pCi), qs dcf for Cs-137 backcalculated from CAP88 as given in DOE-11485 Table $6-5$

Pu-238 $0.0224 .07 e-1 \quad 1.496 e+09 \quad 0.0 \quad$ name, MDA, DCF(mrem/pCi), gs dcf for Pu-238 Sol Class $F$, ref person DOE 1196 Pu-239 $0.0224 .48 e^{-1} \quad 1.360 e+09 \quad 0.0$ name, MDA, DCF (mrem/pCi), qs dcf for Pu-239 Sol Class F, ref person DOE 1196 Sr-90 $0.2155 .88 \mathrm{e}-3 \quad 5.610 \mathrm{e}+10 \quad 0.0$ name, MDA, DCF(mrem/pCi), qs dcf for Sr-90 backcalculated from CAP88 as given in DOE-11485 Table 6-5

I-131 $0.1892 .23 e-3 \quad 3.740 e+11 \quad 8.03$ name, MDA, DCF(mrem/pCi), qs dcf for I-131 backcalculated from CAP88 as given in DOE-11485 Table 6-5 MDA backcalculated from ESER 1st Qrt 2013 report Table B1 168 'NONE'

End of Parameter Definition File






\begin{tabular}{|c|c|c|c|}
\hline Am-241 & $1.680 \mathrm{E}+09$ & 168 & ESER-MOU \\
\hline$A m-241$ & $1.680 \mathrm{E}+09$ & 168 & ESER-BLU \\
\hline Am-241 & $1.680 \mathrm{E}+09$ & 168 & ESER-TER \\
\hline$A m-241$ & $1.680 \mathrm{E}+09$ & 168 & ESER-HOW \\
\hline$A m-241$ & $1.680 \mathrm{E}+09$ & 168 & RWMCS \\
\hline$A m-241$ & $1.680 \mathrm{E}+09$ & 168 & MFCN \\
\hline $\mathrm{Am}-241$ & $1.680 \mathrm{E}+09$ & 168 & MFCGS \\
\hline $\mathrm{Am}-241$ & $1.680 \mathrm{E}+09$ & 168 & Onsite Station \\
\hline$A m-241$ & $1.680 \mathrm{E}+09$ & 168 & Offsitē_Station \\
\hline Cs -137 & $1.465 \mathrm{E}+11$ & 168 & BEA-TRA \\
\hline Cs -137 & $1.465 \mathrm{E}+11$ & 168 & $\mathrm{BEA}-\mathrm{CPP}$ \\
\hline Cs -137 & $1.465 \mathrm{E}+11$ & 168 & BEA-RWMC \\
\hline Cs -137 & $1.465 \mathrm{E}+11$ & 168 & BEA-VAN \\
\hline Cs -137 & $1.465 \mathrm{E}+11$ & 168 & $\mathrm{BEA}-\mathrm{IRC}$ \\
\hline Cs -137 & 1. $465 \mathrm{E}+11$ & 168 & BEA-BLKFT \\
\hline Cs -137 & $1.465 \mathrm{E}+11$ & 168 & BEA-SMC \\
\hline Cs -137 & $1.465 \mathrm{E}+11$ & 168 & BEA-GATE \\
\hline Cs -137 & $1.465 \mathrm{E}+11$ & 168 & BEA-REST \\
\hline Cs -137 & $1.465 \mathrm{E}+11$ & 168 & $\mathrm{BEA}-\mathrm{IF}$ \\
\hline Cs -137 & $1.465 \mathrm{E}+11$ & 168 & $\mathrm{BEA}-\mathrm{NRF}$ \\
\hline Cs -137 & $1.465 \mathrm{E}+11$ & 168 & $\mathrm{BEA}-\mathrm{RTC}$ \\
\hline Cs -137 & $1.465 \mathrm{E}+11$ & 168 & $\mathrm{BEA}-\mathrm{EBR}$ \\
\hline Cs -137 & $1.465 \mathrm{E}+11$ & 168 & $\mathrm{BEA}-\mathrm{MFC}$ \\
\hline Cs -137 & $1.465 \mathrm{E}+11$ & 168 & BEA-SUGAR \\
\hline Cs -137 & $1.465 \mathrm{E}+11$ & 168 & BEA-INTEC \\
\hline Cs -137 & $1.465 \mathrm{E}+11$ & 168 & $\mathrm{BEA}-\mathrm{CFA}$ \\
\hline $\mathrm{Cs}-137$ & $1.465 \mathrm{E}+11$ & 168 & BEA-EFS \\
\hline Cs -137 & $1.465 \mathrm{E}+11$ & 168 & BEA-CRATER \\
\hline Cs -137 & $1.465 \mathrm{E}+11$ & 168 & ESER-VAN \\
\hline Cs -137 & $1.465 \mathrm{E}+11$ & 168 & ESER-CRA \\
\hline Cs -137 & $1.465 \mathrm{E}+11$ & 168 & ESER-ARC \\
\hline Cs -137 & $1.465 \mathrm{E}+11$ & 168 & ESER-SUG \\
\hline Cs -137 & $1.465 \mathrm{E}+11$ & 168 & ESER-IDA \\
\hline $\mathrm{Cs}-137$ & $1.465 \mathrm{E}+11$ & 168 & ESER-DUB \\
\hline Cs -137 & $1.465 \mathrm{E}+11$ & 168 & ESER-MON \\
\hline Cs -137 & $1.465 \mathrm{E}+11$ & 168 & ESER-EFS \\
\hline Cs -137 & $1.465 \mathrm{E}+11$ & 168 & ESER-ATO \\
\hline $\mathrm{Cs}-137$ & $1.465 \mathrm{E}+11$ & 168 & ESER-MOU \\
\hline $\mathrm{Cs}-137$ & $1.465 \mathrm{E}+11$ & 168 & ESER-BLU \\
\hline $\mathrm{Cs}-137$ & $1.465 \mathrm{E}+11$ & 168 & ESER-TER \\
\hline Cs -137 & $1.465 \mathrm{E}+11$ & 168 & ESER-HOW \\
\hline Cs -137 & $1.465 \mathrm{E}+11$ & 168 & RWMCS \\
\hline $\mathrm{Cs}-137$ & $1.465 \mathrm{E}+11$ & 168 & $\mathrm{MFCN}$ \\
\hline Cs -137 & $1.465 \mathrm{E}+11$ & 168 & MFCGS \\
\hline Cs -137 & $1.465 \mathrm{E}+11$ & 168 & Onsite_station \\
\hline Cs -137 & $1.465 \mathrm{E}+11$ & 168 & Offsitē_Station \\
\hline $\mathrm{Pu}-238$ & $1.496 \mathrm{E}+09$ & 168 & BEA-TRA ${ }^{-}$ \\
\hline $\mathrm{Pu}-238$ & $1.496 \mathrm{E}+09$ & 168 & $\mathrm{BEA}-\mathrm{CPP}$ \\
\hline Pu-238 & $1.496 \mathrm{E}+09$ & 168 & BEA-RWMC \\
\hline Pu-238 & $1.496 \mathrm{E}+09$ & 168 & BEA-VAN \\
\hline Pu-238 & $1.496 \mathrm{E}+09$ & 168 & $\mathrm{BEA}-\mathrm{IRC}$ \\
\hline Pu-238 & $1.496 \mathrm{E}+09$ & 168 & BEA-BLKFT \\
\hline Pu-238 & $1.496 \mathrm{E}+09$ & 168 & $\mathrm{BEA}-\mathrm{SMC}$ \\
\hline Pu-238 & $1.496 \mathrm{E}+09$ & 168 & BEA-GATE \\
\hline Pu-238 & $1.496 \mathrm{E}+09$ & 168 & BEA-REST \\
\hline $\mathrm{Pu}-238$ & $1.496 \mathrm{E}+09$ & 168 & $\mathrm{BEA}-\mathrm{IF}$ \\
\hline $\mathrm{Pu}-238$ & $1.496 \mathrm{E}+09$ & 168 & $\mathrm{BEA}-\mathrm{NRF}$ \\
\hline Pu-238 & $1.496 \mathrm{E}+09$ & 168 & $\mathrm{BEA}-\mathrm{RTC}$ \\
\hline $\mathrm{Pu}-238$ & $1.496 \mathrm{E}+09$ & 168 & $\mathrm{BEA}-\mathrm{EBR}$ \\
\hline $\mathrm{Pu}-238$ & $1.496 \mathrm{E}+09$ & 168 & $\mathrm{BEA}-\mathrm{MFC}$ \\
\hline $\mathrm{Pu}-238$ & $1.496 \mathrm{E}+09$ & 168 & BEA-SUGAR \\
\hline Pu-238 & $1.496 \mathrm{E}+09$ & 168 & BEA-INTEC \\
\hline Pu-238 & $1.496 \mathrm{E}+09$ & 168 & $\mathrm{BEA}-\mathrm{CFA}$ \\
\hline $\mathrm{Pu}-238$ & $1.496 \mathrm{E}+09$ & 168 & $\mathrm{BEA}-\mathrm{EFS}$ \\
\hline Pu-238 & $1.496 \mathrm{E}+09$ & 168 & BEA-CRATER \\
\hline Pu-238 & $1.496 \mathrm{E}+09$ & 168 & ESER-VAN \\
\hline Pu-238 & $1.496 \mathrm{E}+09$ & 168 & ESER-CRA \\
\hline $\mathrm{Pu}-238$ & $1.496 \mathrm{E}+09$ & 168 & ESER-ARC \\
\hline Pu-238 & $1.496 \mathrm{E}+09$ & 168 & ESER-SUG \\
\hline $\mathrm{Pu}-238$ & $1.496 \mathrm{E}+09$ & 168 & ESER-IDA \\
\hline Pu-238 & $1.496 \mathrm{E}+09$ & 168 & ESER-DUB \\
\hline Pu-238 & $1.496 \mathrm{E}+09$ & 168 & ESER-MON \\
\hline $\mathrm{Pu}-238$ & $1.496 \mathrm{E}+09$ & 168 & ESER-EFS \\
\hline $\mathrm{Pu}-238$ & $1.496 \mathrm{E}+09$ & 168 & ESER-ATO \\
\hline $\mathrm{Pu}-238$ & $1.496 \mathrm{E}+09$ & 168 & ESER-MOU \\
\hline $\mathrm{Pu}-238$ & $1.496 \mathrm{E}+09$ & 168 & ESER-BLU \\
\hline Pu-238 & $1.496 \mathrm{E}+09$ & 168 & ESER-TER \\
\hline $\mathrm{Pu}-238$ & $1.496 \mathrm{E}+09$ & 168 & ESER-HOW \\
\hline $\mathrm{Pu}-238$ & $1.496 \mathrm{E}+09$ & 168 & RWMCS \\
\hline Pu-238 & $1.496 \mathrm{E}+09$ & 168 & $\mathrm{MFCN}$ \\
\hline $\mathrm{Pu}-238$ & $1.496 \mathrm{E}+09$ & 168 & MFCGS \\
\hline $\mathrm{Pu}-238$ & $1.496 \mathrm{E}+09$ & 168 & Onsite_Station \\
\hline $\mathrm{Pu}-238$ & $1.496 \mathrm{E}+09$ & 168 & Offsite Station \\
\hline $\mathrm{Pu}-239$ & $1.360 \mathrm{E}+09$ & 168 & $\mathrm{BEA}-\mathrm{TRA}$ \\
\hline $\mathrm{Pu}-239$ & $1.360 \mathrm{E}+09$ & 168 & $\mathrm{BEA}-\mathrm{CPP}$ \\
\hline $\mathrm{Pu}-239$ & $1.360 \mathrm{E}+09$ & 168 & BEA-RWMC \\
\hline $\mathrm{Pu}-239$ & $1.360 \mathrm{E}+09$ & 168 & BEA-VAN \\
\hline $\mathrm{Pu}-239$ & $1.360 \mathrm{E}+09$ & 168 & $\mathrm{BEA}-\mathrm{IRC}$ \\
\hline $\mathrm{Pu}-239$ & $1.360 \mathrm{E}+09$ & 168 & BEA-BLKFT \\
\hline $\mathrm{Pu}-239$ & $1.360 \mathrm{E}+09$ & 168 & BEA-SMC \\
\hline $\mathrm{Pu}-239$ & $1.360 \mathrm{E}+09$ & 168 & BEA-GATE \\
\hline $\mathrm{Pu}-239$ & $1.360 \mathrm{E}+09$ & 168 & BEA-REST \\
\hline $\mathrm{Pu}-239$ & $1.360 \mathrm{E}+09$ & 168 & $\mathrm{BEA}-\mathrm{IF}$ \\
\hline $\mathrm{Pu}-239$ & $1.360 \mathrm{E}+09$ & 168 & $\mathrm{BEA}-\mathrm{NRF}$ \\
\hline Pu-239 & $1.360 \mathrm{E}+09$ & 168 & $\mathrm{BEA}-\mathrm{RTC}$ \\
\hline
\end{tabular}




\begin{tabular}{|c|c|c|c|}
\hline Pu-239 & $1.360 \mathrm{E}+09$ & 168 & $\mathrm{BEA}-\mathrm{EBR}$ \\
\hline Pu-239 & $1.360 \mathrm{E}+09$ & 168 & $\mathrm{BEA}-\mathrm{MFC}$ \\
\hline $\mathrm{Pu}-239$ & $1.360 \mathrm{E}+09$ & 168 & BEA-SUGAR \\
\hline Pu-239 & $1.360 \mathrm{E}+09$ & 168 & BEA-INTEC \\
\hline Pu-239 & $1.360 \mathrm{E}+09$ & 168 & $\mathrm{BEA}-\mathrm{CFA}$ \\
\hline $\mathrm{Pu}-239$ & $1.360 \mathrm{E}+09$ & 168 & BEA-EFS \\
\hline $\mathrm{Pu}-239$ & $1.360 \mathrm{E}+09$ & 168 & BEA-CRATER \\
\hline Pu-239 & $1.360 \mathrm{E}+09$ & 168 & ESER-VAN \\
\hline Pu-239 & $1.360 \mathrm{E}+09$ & 168 & ESER-CRA \\
\hline Pu-239 & $1.360 \mathrm{E}+09$ & 168 & ESER-ARC \\
\hline Pu-239 & $1.360 \mathrm{E}+09$ & 168 & ESER-SUG \\
\hline Pu-239 & $1.360 \mathrm{E}+09$ & 168 & ESER-IDA \\
\hline Pu-239 & $1.360 \mathrm{E}+09$ & 168 & ESER-DUB \\
\hline Pu-239 & $1.360 \mathrm{E}+09$ & 168 & ESER-MON \\
\hline Pu-239 & $1.360 \mathrm{E}+09$ & 168 & ESER-EFS \\
\hline $\mathrm{Pu}-239$ & $1.360 \mathrm{E}+09$ & 168 & ESER-ATO \\
\hline Pu-239 & $1.360 \mathrm{E}+09$ & 168 & ESER-MOU \\
\hline Pu-239 & $1.360 \mathrm{E}+09$ & 168 & ESER-BLU \\
\hline Pu-239 & $1.360 \mathrm{E}+09$ & 168 & ESER-TER \\
\hline Pu-239 & $1.360 \mathrm{E}+09$ & 168 & ESER-HOW \\
\hline $\mathrm{Pu}-239$ & $1.360 \mathrm{E}+09$ & 168 & RWMCS \\
\hline Pu-239 & $1.360 \mathrm{E}+09$ & 168 & $\mathrm{MFCN}$ \\
\hline $\mathrm{Pu}-239$ & $1.360 \mathrm{E}+09$ & 168 & MFCGS \\
\hline Pu-239 & $1.360 \mathrm{E}+09$ & 168 & Onsite Station \\
\hline $\mathrm{Pu}-239$ & $1.360 \mathrm{E}+09$ & 168 & Offsite Station \\
\hline $\mathrm{Sr}-90$ & $5.610 \mathrm{E}+10$ & 168 & BEA-TRA \\
\hline $\mathrm{Sr}-90$ & $5.610 \mathrm{E}+10$ & 168 & $\mathrm{BEA}-\mathrm{CPP}$ \\
\hline $\mathrm{Sr}-90$ & $5.610 \mathrm{E}+10$ & 168 & BEA-RWMC \\
\hline $\mathrm{Sr}-90$ & $5.610 \mathrm{E}+10$ & 168 & BEA-VAN \\
\hline $\mathrm{Sr}-90$ & $5.610 \mathrm{E}+10$ & 168 & BEA-IRC \\
\hline $\mathrm{Sr}-90$ & $5.610 \mathrm{E}+10$ & 168 & BEA-BLKFT \\
\hline $\mathrm{Sr}-90$ & $5.610 \mathrm{E}+10$ & 168 & $\mathrm{BEA}-\mathrm{SMC}$ \\
\hline $\mathrm{Sr}-90$ & $5.610 \mathrm{E}+10$ & 168 & BEA-GATE \\
\hline $\mathrm{Sr}-90$ & $5.610 \mathrm{E}+10$ & 168 & BEA-REST \\
\hline $\mathrm{Sr}-90$ & $5.610 \mathrm{E}+10$ & 168 & $B E A-I F$ \\
\hline $\mathrm{Sr}-90$ & $5.610 \mathrm{E}+10$ & 168 & $\mathrm{BEA}-\mathrm{NRF}$ \\
\hline $\mathrm{Sr}-90$ & $5.610 \mathrm{E}+10$ & 168 & BEA-RTC \\
\hline $\mathrm{Sr}-90$ & $5.610 \mathrm{E}+10$ & 168 & BEA-EBR \\
\hline $\mathrm{Sr}-90$ & $5.610 \mathrm{E}+10$ & 168 & $\mathrm{BEA}-\mathrm{MFC}$ \\
\hline $\mathrm{Sr}-90$ & $5.610 \mathrm{E}+10$ & 168 & BEA-SUGAR \\
\hline $\mathrm{Sr}-90$ & $5.610 \mathrm{E}+10$ & 168 & BEA-INTEC \\
\hline $\mathrm{Sr}-90$ & $5.610 \mathrm{E}+10$ & 168 & $\mathrm{BEA}-\mathrm{CFA}$ \\
\hline $\mathrm{Sr}-90$ & $5.610 \mathrm{E}+10$ & 168 & BEA-EFS \\
\hline $\mathrm{Sr}-90$ & $5.610 \mathrm{E}+10$ & 168 & BEA-CRATER \\
\hline $\mathrm{Sr}-90$ & $5.610 \mathrm{E}+10$ & 168 & ESER-VAN \\
\hline $\mathrm{Sr}-90$ & $5.610 \mathrm{E}+10$ & 168 & ESER-CRA \\
\hline $\mathrm{Sr}-90$ & $5.610 \mathrm{E}+10$ & 168 & ESER-ARC \\
\hline $\mathrm{Sr}-90$ & $5.610 \mathrm{E}+10$ & 168 & ESER-SUG \\
\hline $\mathrm{Sr}-90$ & $5.610 \mathrm{E}+10$ & 168 & ESER-IDA \\
\hline $\mathrm{Sr}-90$ & $5.610 \mathrm{E}+10$ & 168 & ESER-DUB \\
\hline $\mathrm{Sr}-90$ & $5.610 \mathrm{E}+10$ & 168 & ESER-MON \\
\hline $\mathrm{Sr}-90$ & $5.610 \mathrm{E}+10$ & 168 & ESER-EFS \\
\hline $\mathrm{Sr}-90$ & $5.610 \mathrm{E}+10$ & 168 & ESER-ATO \\
\hline $\mathrm{Sr}-90$ & $5.610 \mathrm{E}+10$ & 168 & ESER-MOU \\
\hline $\mathrm{Sr}-90$ & $5.610 \mathrm{E}+10$ & 168 & ESER-BLU \\
\hline $\mathrm{Sr}-90$ & $5.610 \mathrm{E}+10$ & 168 & ESER-TER \\
\hline $\mathrm{Sr}-90$ & $5.610 \mathrm{E}+10$ & 168 & ESER-HOW \\
\hline $\mathrm{Sr}-90$ & $5.610 \mathrm{E}+10$ & 168 & RWMCS \\
\hline $\mathrm{Sr}-90$ & $5.610 \mathrm{E}+10$ & 168 & $\mathrm{MFCN}$ \\
\hline $\mathrm{Sr}-90$ & $5.610 \mathrm{E}+10$ & 168 & MFCGS \\
\hline $\mathrm{Sr}-90$ & $5.610 \mathrm{E}+10$ & 168 & Onsite Station \\
\hline $\mathrm{Sr}-90$ & $5.610 \mathrm{E}+10$ & 168 & offsitè Station \\
\hline$I-131$ & $3.740 \mathrm{E}+11$ & 168 & BEA-TRA \\
\hline I-131 & $3.740 \mathrm{E}+11$ & 168 & $\mathrm{BEA}-\mathrm{CPP}$ \\
\hline I-131 & $3.740 \mathrm{E}+11$ & 168 & BEA-RWMC \\
\hline$I-131$ & $3.740 \mathrm{E}+11$ & 168 & BEA-VAN \\
\hline I-131 & $3.740 \mathrm{E}+11$ & 168 & BEA-IRC \\
\hline$I-131$ & $3.740 \mathrm{E}+11$ & 168 & BEA-BLKFT \\
\hline$I-131$ & $3.740 \mathrm{E}+11$ & 168 & BEA-SMC \\
\hline$I-131$ & $3.740 \mathrm{E}+11$ & 168 & BEA-GATE \\
\hline$I-131$ & $3.740 \mathrm{E}+11$ & 168 & BEA-REST \\
\hline I-131 & $3.740 \mathrm{E}+11$ & 168 & $\mathrm{BEA}-\mathrm{IF}$ \\
\hline$I-131$ & $3.740 \mathrm{E}+11$ & 168 & $\mathrm{BEA}-\mathrm{NRF}$ \\
\hline$I-131$ & $3.740 \mathrm{E}+11$ & 168 & BEA-RTC \\
\hline$I-131$ & $3.740 \mathrm{E}+11$ & 168 & BEA-EBR \\
\hline$I-131$ & $3.740 \mathrm{E}+11$ & 168 & BEA-MFC \\
\hline I-131 & $3.740 \mathrm{E}+11$ & 168 & BEA-SUGAR \\
\hline$I-131$ & $3.740 \mathrm{E}+11$ & 168 & BEA-INTEC \\
\hline$I-131$ & $3.740 \mathrm{E}+11$ & 168 & $\mathrm{BEA}-\mathrm{CFA}$ \\
\hline I-131 & $3.740 \mathrm{E}+11$ & 168 & BEA-EFS \\
\hline I-131 & $3.740 \mathrm{E}+11$ & 168 & BEA-CRATER \\
\hline$I-131$ & $3.740 \mathrm{E}+11$ & 168 & ESER-VAN \\
\hline I-131 & $3.740 \mathrm{E}+11$ & 168 & ESER-CRA \\
\hline I-131 & $3.740 \mathrm{E}+11$ & 168 & ESER-ARC \\
\hline I-131 & $3.740 \mathrm{E}+11$ & 168 & ESER-SUG \\
\hline I-131 & $3.740 \mathrm{E}+11$ & 168 & ESER-IDA \\
\hline$I-131$ & $3.740 \mathrm{E}+11$ & 168 & ESER-DUB \\
\hline$I-131$ & $3.740 \mathrm{E}+11$ & 168 & ESER-MON \\
\hline I-131 & $3.740 \mathrm{E}+11$ & 168 & ESER-EFS \\
\hline$I-131$ & $3.740 \mathrm{E}+11$ & 168 & ESER-ATO \\
\hline$I-131$ & $3.740 \mathrm{E}+11$ & 168 & ESER-MOU \\
\hline$I-131$ & $3.740 \mathrm{E}+11$ & 168 & ESER-BLU \\
\hline$I-131$ & $3.740 \mathrm{E}+11$ & 168 & ESER-TER \\
\hline$I-131$ & $3.740 \mathrm{E}+11$ & 168 & ESER-HOW \\
\hline$I-131$ & $3.740 \mathrm{E}+11$ & 168 & RWMCS \\
\hline
\end{tabular}




$\begin{array}{llllr}I-131 & 3.740 \mathrm{E}+11 & 168 & \text { MFCN } & 9.810 \mathrm{E}-01 \\ \mathrm{I}-131 & 3.740 \mathrm{E}+11 & 168 & \text { MFCGS } & 9.797 \mathrm{E}-01 \\ \mathrm{I}-131 & 3.740 \mathrm{E}+11 & 168 & \text { Onsite_Station } & 1.000 \mathrm{E}+00 \\ \mathrm{I}-131 & 3.740 \mathrm{E}+11 & 168 & \text { Offsite_Station } & 0.000 \mathrm{E}+00\end{array}$

RESIDENT SCENARIO, EXISTING NETWORK, OPTIMIZED FOR RWMC

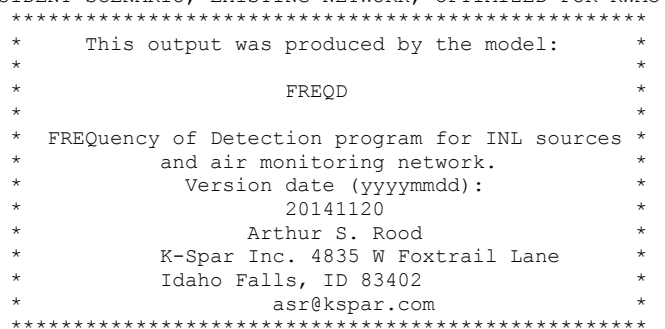

Date: 05/16/2015 Time: 21:26:44.457

Input File: freqd.par

START OF PARAMETER DEFINITION FILE

FreqD.f95 - Evaluation of existing network for 168-hr release yielding $1 \mathrm{mrem} / \mathrm{yr}$ Data File:../././TICSALL/RWMC_combine.txt

67

\begin{tabular}{|c|c|c|c|}
\hline$A-T R A$ & 3.398 & 168 & \\
\hline $\mathrm{BEA}-\mathrm{CPP}$ & 3.398 & 168 & \\
\hline BEA-RWMC & 3.398 & 168 & \\
\hline BEA-VAN & 3.398 & 168 & \\
\hline BEA-IRC & 3.398 & 168 & \\
\hline BEA-BLKFT & 3.398 & $8 \quad 168$ & \\
\hline $\mathrm{BEA}-\mathrm{SMC}$ & 3.398 & 168 & \\
\hline BEA-GATE & 3.398 & 168 & \\
\hline BEA-ARA & 3.398 & 168 & \\
\hline BEA-REST & 3.398 & 168 & \\
\hline $\mathrm{BEA}-\mathrm{IF}$ & 3.398 & 168 & \\
\hline $\mathrm{BEA}-\mathrm{NRF}$ & 3.398 & 168 & \\
\hline $\mathrm{BEA}-\mathrm{RTC}$ & 3.398 & 168 & \\
\hline $\mathrm{BEA}-\mathrm{EBR}$ & 3.398 & 168 & \\
\hline $\mathrm{BEA}-\mathrm{MFC}$ & 3.398 & 168 & \\
\hline BEA-SUGAR & $\begin{array}{l}2.398 \\
2\end{array}$ & 168 & \\
\hline $\mathrm{BEA}-\mathrm{PBF}$ & 3.398 & 168 & \\
\hline BEA-INTEC & 3.398 & 168 & \\
\hline $\mathrm{BEA}-\mathrm{CFA}$ & 3.398 & 168 & \\
\hline $\mathrm{BEA}-\mathrm{EFS}$ & 3.398 & 168 & \\
\hline BEA-CRATER & R $\quad 3.39$ & 168 & \\
\hline ESER-VAN & 3.398 & 168 & \\
\hline ESER-CRA & 3.398 & 168 & \\
\hline ESER-ARC & 3.398 & 168 & \\
\hline ESER-SUG & 3.398 & 168 & \\
\hline ESER-IDA & 3.398 & 168 & \\
\hline ESER-DUB & 3.398 & 168 & \\
\hline ESER-MON & 3.398 & 168 & \\
\hline ESER-FAA & 3.398 & 168 & \\
\hline ESER-MAI & 3.398 & 168 & \\
\hline ESER-EFS & 3.398 & 168 & \\
\hline ESER-ATO & 3.398 & 168 & \\
\hline ESER-MOU & 3.398 & 168 & \\
\hline ESER-BLU & 3.398 & 168 & \\
\hline ESER-TER & 3.398 & 168 & \\
\hline ESER-HOW & 3.398 & 168 & \\
\hline MEI01 & 398 & 168 & 1 \\
\hline MEI02 & 3.398 & 168 & 1 \\
\hline MEI03 & 3.398 & 168 & 1 \\
\hline MEIO 4 & 3.398 & 168 & 1 \\
\hline MEI05 & 3.398 & 168 & 1 \\
\hline MEIO 6 & 3.398 & 168 & 1 \\
\hline MEI07 & 3.398 & 168 & 1 \\
\hline MEI08 & 3.398 & 168 & 1 \\
\hline MEIO9 & 3.398 & 168 & 1 \\
\hline MEI10 & 3.398 & 168 & 1 \\
\hline MEI11 & 3.398 & 168 & 1 \\
\hline MEI12 & 3.398 & 168 & 1 \\
\hline $\operatorname{MEI} 13$ & 3.398 & 168 & 1 \\
\hline MEI14 & .398 & 168 & 1 \\
\hline MEI15 & 3.398 & 168 & 1 \\
\hline MEI16 & 3.398 & 168 & 1 \\
\hline MEI17 & 3.398 & 168 & 1 \\
\hline MEI18 & 3.398 & 168 & 1 \\
\hline MEI19 & 3.398 & 168 & 1 \\
\hline MEI 20 & 3.398 & 168 & 1 \\
\hline MEI21 & 3.398 & 168 & 1 \\
\hline MEI22 & 3.398 & 168 & 1 \\
\hline MEI23 & 3.398 & 168 & 1 \\
\hline $\operatorname{MEI} 24$ & 3.398 & 168 & 1 \\
\hline MEI25 & 3.398 & 168 & 1 \\
\hline $\operatorname{MEI} 26$ & 3.398 & 168 & 1 \\
\hline $\operatorname{MEI} 27$ & 3.398 & 168 & 1 \\
\hline RWMCS & 3.398 & 168 & 1 \\
\hline $\mathrm{MFCN}$ & 3.398 & 168 & 1 \\
\hline - & 3.398 & 168 & 1 \\
\hline & & & \\
\hline
\end{tabular}

sampname, flowr, rtime, onsite, incsamp sampname, flowr, rtime, onsite, incsamp sampname, flowr, rtime, onsite, incsamp sampname, flowr, rtime, onsite, incsamp sampname, flowr, rtime, onsite, incsamp sampname, flowr, rtime, onsite, incsamp sampname, flowr, rtime, onsite, incsamp sampname, flowr, rtime, onsite, incsamp sampname, flowr, rtime, onsite, incsamp sampname, flowr, rtime, onsite, incsamp sampname, flowr, rtime, onsite, incsamp sampname, flowr, rtime, onsite, incsamp samprame, flowr, rtime, onsite, incsamp samphane, flowr, rtime, onsite, lncsamp sampname, flowr, rtime, onsite, lncsamp sampname, flowr, rtime, onsite, incsamp sampname, flowr, rtime, onsite, incsamp sampname, flowr, rtime, onsite, incsamp sampname, flowr, rtime, onsite, incsamp sampname, flowr, rtime, onsite, incsamp sampname, flowr, rtime, onsite, incsamp sampname, flowr, rtime, onsite, incsamp sampname, flowr, rtime, onsite, incsamp sampname, flowr, rtime, onsite, incsamp samphame, flowr, rtime, onsite, lncsamp sampran, flowr, rtime, onsite, incsamp samphame, flowr, rtime, onsite, lncsamp sampname, flowr, rtime, onsite, incsamp sampname, flowr, rtime, onsite, incsamp sampname, flowr, rtime, onsite, incsamp sampname, flowr, rtime, onsite, incsamp sampname, flowr, rtime, onsite, incsamp sampname, flowr, rtime, onsite, incsamp sampname, flowr, rtime, onsite, incsamp sampname, flowr, rtime, onsite, incsamp sampname, flowr, rtime, onsite, incsamp sampname, flowr, rtime, onsite, incsamp samphane, flowr, rtine, onsite, incsanp sampnam, flowr, rtime, onsite, incsamp samphame, flowr, rtime, onsite, incsamp sampname, flowr, rtime, onsite, incsamp sampname, flowr, rtime, onsite, incsamp sampname, flowr, rtime, onsite, incsamp sampname, flowr, rtime, onsite, incsamp sampname, flowr, rtime, onsite, incsamp sampname, flowr, rtime, onsite, incsamp sampname, flowr, rtime, onsite, incsamp sampname, flowr, rtime, onsite, incsamp sampname, flowr, rtime, onsite, incsamp sampname, flowr, rtime, onsite, incsamp sampnam, flowr, rtime, onsite, incsamp sampname, flowr, rtime, onsite, incsamp sampname, flowr, rtime, onsite, incsamp sampname, flowr, rtime, onsite, incsamp sampname, flowr, rtime, onsite, incsamp sampname, flowr, rtime, onsite, incsamp sampname, flowr, rtime, onsite, incsamp sampname, flowr, rtime, onsite, incsamp sampname, flowr, rtime, onsite, incsamp sampnamer, flowr, rtimer onsiter, incsamp sampname, flowr, rtime, onsite, incsamp sampname, flowr, rtime, onsite, incsamp sanpame, flowr, rtime, onsite, incsamp sampname, flowr, rtime, onsite, incsamp sampname, flowr, rtime, onsite, incsamp sampname, flowr, rtime, onsite, incsamp sampname, flowr, rtime, onsite, incsamp sampname, flowr, rtime, onsite, incsamp sampname, flowr, rtime, onsite, incsamp sampname, flowr, rtime, onsite, incsamp sampname, flowr, rtime, onsite, incsamp 


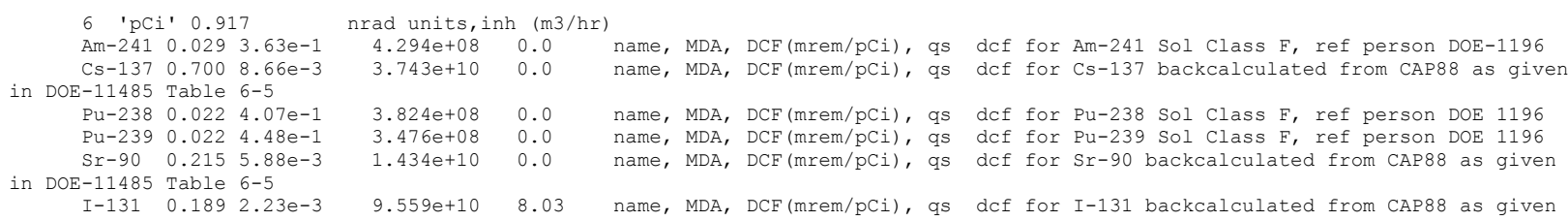

\begin{tabular}{|c|c|c|}
\hline 168 & BEA-TRA & $7.900 \mathrm{E}-01$ \\
\hline 168 & $\mathrm{BEA}-\mathrm{CPP}$ & $8.653 \mathrm{E}-01$ \\
\hline 168 & BEA-RWMC & $1.000 \mathrm{E}+00$ \\
\hline 168 & BEA-VAN & $9.923 \mathrm{E}-01$ \\
\hline 168 & BEA-IRC & $0.000 \mathrm{E}+00$ \\
\hline 168 & BEA-BLKFT & $0.000 \mathrm{E}+00$ \\
\hline 168 & $\mathrm{BEA}-\mathrm{SMC}$ & $0.000 \mathrm{E}+00$ \\
\hline 168 & BEA-GATE & $0.000 \mathrm{E}+00$ \\
\hline 168 & BEA-REST & $9.966 \mathrm{E}-01$ \\
\hline 168 & $\mathrm{BEA}-\mathrm{IF}$ & $0.000 \mathrm{E}+00$ \\
\hline 168 & BEA-NRF & $1.271 \mathrm{E}-01$ \\
\hline 168 & $\mathrm{BEA}-\mathrm{RTC}$ & $7.082 \mathrm{E}-01$ \\
\hline 168 & $\mathrm{BEA}-\mathrm{EBR}$ & $9.958 \mathrm{E}-01$ \\
\hline 168 & $\mathrm{BEA}-\mathrm{MFC}$ & $0.000 \mathrm{E}+00$ \\
\hline 168 & BEA-SUGAR & $0.000 \mathrm{E}+00$ \\
\hline 168 & BEA-INTEC & $8.075 \mathrm{E}-01$ \\
\hline 168 & $\mathrm{BEA}-\mathrm{CFA}$ & $8.913 \mathrm{E}-01$ \\
\hline 168 & BEA-EFS & $5.029 \mathrm{E}-01$ \\
\hline 168 & BEA-CRATER & $0.000 \mathrm{E}+00$ \\
\hline 168 & ESER-VAN & $9.923 \mathrm{E}-01$ \\
\hline 168 & ESER-CRA & $0.000 \mathrm{E}+00$ \\
\hline 168 & ESER-ARC & $0.000 \mathrm{E}+00$ \\
\hline 168 & ESER-SUG & $0.000 \mathrm{E}+00$ \\
\hline 168 & ESER-IDA & $0.000 \mathrm{E}+00$ \\
\hline 168 & ESER-DUB & $0.000 \mathrm{E}+00$ \\
\hline 168 & ESER-MON & $0.000 \mathrm{E}+00$ \\
\hline 168 & ESER-EFS & $5.018 \mathrm{E}-01$ \\
\hline 168 & ESER-ATO & $1.339 \mathrm{E}-01$ \\
\hline 168 & ESER-MOU & $0.000 \mathrm{E}+00$ \\
\hline 168 & ESER-BLU & $0.000 \mathrm{E}+00$ \\
\hline 168 & ESER-TER & $0.000 \mathrm{E}+00$ \\
\hline 168 & ESER-HOW & $0.000 \mathrm{E}+00$ \\
\hline 168 & RWMCS & $9.972 \mathrm{E}-01$ \\
\hline 168 & $\mathrm{MFCN}$ & $0.000 \mathrm{E}+00$ \\
\hline 168 & MFCGS & $0.000 \mathrm{E}+00$ \\
\hline 168 & Onsite Station & $1.000 \mathrm{E}+00$ \\
\hline 168 & Offsite Station & $0.000 \mathrm{E}+00$ \\
\hline 168 & BEA-TRA- & $9.980 \mathrm{E}-01$ \\
\hline 168 & $\mathrm{BEA}-\mathrm{CPP}$ & $9.991 \mathrm{E}-01$ \\
\hline 168 & BEA-RWMC & $1.000 \mathrm{E}+00$ \\
\hline 168 & $\mathrm{BEA}-\mathrm{VAN}$ & $1.000 \mathrm{E}+00$ \\
\hline 168 & $\mathrm{BEA}-\mathrm{IRC}$ & $0.000 \mathrm{E}+00$ \\
\hline 168 & BEA-BLKFT & $0.000 \mathrm{E}+00$ \\
\hline 168 & BEA-SMC & $2.561 \mathrm{E}-03$ \\
\hline 168 & BEA-GATE & $1.654 \mathrm{E}-01$ \\
\hline 168 & BEA-REST & $1.000 \mathrm{E}+00$ \\
\hline 168 & $\mathrm{BEA}-\mathrm{IF}$ & $0.000 \mathrm{E}+00$ \\
\hline 168 & $\mathrm{BEA}-\mathrm{NRF}$ & $8.363 \mathrm{E}-01$ \\
\hline 168 & BEA-RTC & $9.931 \mathrm{E}-01$ \\
\hline 168 & $\mathrm{BEA}-\mathrm{EBR}$ & $1.000 \mathrm{E}+00$ \\
\hline 168 & $\mathrm{BEA}-\mathrm{MFC}$ & $1.614 \mathrm{E}-01$ \\
\hline 168 & BEA-SUGAR & $0.000 \mathrm{E}+00$ \\
\hline 168 & BEA-INTEC & $9.971 \mathrm{E}-01$ \\
\hline 168 & $\mathrm{BEA}-\mathrm{CFA}$ & $9.950 \mathrm{E}-01$ \\
\hline 168 & BEA-EFS & $9.708 \mathrm{E}-01$ \\
\hline 168 & BEA-CRATER & $0.000 \mathrm{E}+00$ \\
\hline 168 & ESER-VAN & $1.000 \mathrm{E}+00$ \\
\hline 168 & ESER-CRA & $0.000 \mathrm{E}+00$ \\
\hline 168 & ESER-ARC & $1.816 \mathrm{E}-02$ \\
\hline 168 & ESER-SUG & $0.000 \mathrm{E}+00$ \\
\hline 168 & ESER-IDA & $0.000 \mathrm{E}+00$ \\
\hline 168 & ESER-DUB & $0.000 \mathrm{E}+00$ \\
\hline 168 & ESER-MON & $0.000 \mathrm{E}+00$ \\
\hline 168 & ESER-EFS & $9.708 \mathrm{E}-01$ \\
\hline 168 & ESER-ATO & $5.361 \mathrm{E}-01$ \\
\hline 168 & ESER-MOU & $0.000 \mathrm{E}+00$ \\
\hline 168 & ESER-BLU & $0.000 \mathrm{E}+00$ \\
\hline 168 & ESER-TER & $0.000 \mathrm{E}+00$ \\
\hline 168 & ESER-HOW & $0.000 \mathrm{E}+00$ \\
\hline 168 & RWMCS & $9.973 \mathrm{E}-01$ \\
\hline 168 & $\mathrm{MFCN}$ & $1.598 \mathrm{E}-01$ \\
\hline 168 & MFCGS & $1.641 \mathrm{E}-01$ \\
\hline 168 & Onsite Station & $1.000 \mathrm{E}+00$ \\
\hline 168 & Offsite Station & $0.000 \mathrm{E}+00$ \\
\hline 168 & $\mathrm{BEA}-\mathrm{TRA}$ & $8.746 \mathrm{E}-01$ \\
\hline 168 & $\mathrm{BEA}-\mathrm{CPP}$ & $9.279 \mathrm{E}-01$ \\
\hline 168 & BEA-RWMC & $1.000 \mathrm{E}+00$ \\
\hline
\end{tabular}

$3.229 \mathrm{E}-01$

$0.000 \mathrm{E}+00$

$4.276 \mathrm{E}-01$

$0.000 \mathrm{E}+00$ 


\begin{tabular}{|c|c|c|c|}
\hline Pu-238 & $3.824 \mathrm{E}+08$ & 168 & BEA-VAN \\
\hline Pu-238 & $3.824 \mathrm{E}+08$ & 168 & $B E A-I R C$ \\
\hline Pu-238 & $3.824 \mathrm{E}+08$ & 168 & BEA-BLKFT \\
\hline Pu-238 & $3.824 \mathrm{E}+08$ & 168 & BEA-SMC \\
\hline Pu-238 & $3.824 \mathrm{E}+08$ & 168 & BEA-GATE \\
\hline Pu-238 & $3.824 \mathrm{E}+08$ & 168 & BEA-REST \\
\hline Pu-238 & $3.824 \mathrm{E}+08$ & 168 & $B E A-I F$ \\
\hline Pu-238 & $3.824 \mathrm{E}+08$ & 168 & BEA-NRF \\
\hline Pu-238 & $3.824 \mathrm{E}+08$ & 168 & BEA-RTC \\
\hline Pu-238 & $3.824 \mathrm{E}+08$ & 168 & $\mathrm{BEA}-\mathrm{EBR}$ \\
\hline Pu-238 & $3.824 \mathrm{E}+08$ & 168 & BEA-MFC \\
\hline Pu-238 & $3.824 \mathrm{E}+08$ & 168 & BEA-SUGAR \\
\hline Pu-238 & $3.824 \mathrm{E}+08$ & 168 & BEA-INTEC \\
\hline Pu-238 & $3.824 \mathrm{E}+08$ & 168 & $\mathrm{BEA}-\mathrm{CFA}$ \\
\hline Pu-238 & $3.824 \mathrm{E}+08$ & 168 & BEA-EFS \\
\hline Pu-238 & $3.824 \mathrm{E}+08$ & 168 & BEA-CRATER \\
\hline Pu-238 & $3.824 \mathrm{E}+08$ & 168 & ESER-VAN \\
\hline Pu-238 & $3.824 \mathrm{E}+08$ & 168 & ESER-CRA \\
\hline Pu-238 & $3.824 \mathrm{E}+08$ & 168 & ESER-ARC \\
\hline Pu-238 & $3.824 \mathrm{E}+08$ & 168 & ESER-SUG \\
\hline Pu-238 & $3.824 \mathrm{E}+08$ & 168 & ESER-IDA \\
\hline Pu-238 & $3.824 \mathrm{E}+08$ & 168 & ESER-DUB \\
\hline Pu-238 & $3.824 \mathrm{E}+08$ & 168 & ESER-MON \\
\hline Pu-238 & $3.824 \mathrm{E}+08$ & 168 & ESER-EFS \\
\hline Pu-238 & $3.824 \mathrm{E}+08$ & 168 & ESER-ATO \\
\hline $\mathrm{Pu}-238$ & $3.824 \mathrm{E}+08$ & 168 & ESER-MOU \\
\hline Pu-238 & $3.824 \mathrm{E}+08$ & 168 & ESER-BLU \\
\hline Pu-238 & $3.824 \mathrm{E}+08$ & 168 & ESER-TER \\
\hline Pu-238 & $3.824 \mathrm{E}+08$ & 168 & ESER-HOW \\
\hline Pu-238 & $3.824 \mathrm{E}+08$ & 168 & RWMCS \\
\hline Pu-238 & $3.824 \mathrm{E}+08$ & 168 & $\mathrm{MFCN}$ \\
\hline Pu-238 & $3.824 \mathrm{E}+08$ & 168 & MFCGS \\
\hline Pu-238 & $3.824 \mathrm{E}+08$ & 168 & Onsite_Station \\
\hline Pu-238 & $3.824 \mathrm{E}+08$ & 168 & Offsité Station \\
\hline Pu-239 & $3.476 \mathrm{E}+08$ & 168 & BEA-TRA \\
\hline Pu-239 & $3.476 \mathrm{E}+08$ & 168 & $\mathrm{BEA}-\mathrm{CPP}$ \\
\hline Pu-239 & $3.476 \mathrm{E}+08$ & 168 & BEA-RWMC \\
\hline Pu-239 & $3.476 \mathrm{E}+08$ & 168 & BEA-VAN \\
\hline Pu-239 & $3.476 \mathrm{E}+08$ & 168 & BEA-IRC \\
\hline Pu-239 & $3.476 \mathrm{E}+08$ & 168 & BEA-BLKFT \\
\hline Pu-239 & $3.476 \mathrm{E}+08$ & 168 & BEA-SMC \\
\hline Pu-239 & $3.476 \mathrm{E}+08$ & 168 & BEA-GATE \\
\hline Pu-239 & $3.476 \mathrm{E}+08$ & 168 & BEA-REST \\
\hline $\mathrm{Pu}-239$ & $3.476 \mathrm{E}+08$ & 168 & $\mathrm{BEA}-\mathrm{IF}$ \\
\hline Pu-239 & $3.476 \mathrm{E}+08$ & 168 & $\mathrm{BEA}-\mathrm{NRF}$ \\
\hline Pu-239 & $3.476 \mathrm{E}+08$ & 168 & BEA-RTC \\
\hline $\mathrm{Pu}-239$ & $3.476 \mathrm{E}+08$ & 168 & $\mathrm{BEA}-\mathrm{EBR}$ \\
\hline Pu-239 & $3.476 \mathrm{E}+08$ & 168 & BEA-MFC \\
\hline Pu-239 & $3.476 \mathrm{E}+08$ & 168 & BEA-SUGAR \\
\hline Pu-239 & $3.476 \mathrm{E}+08$ & 168 & BEA-INTEC \\
\hline Pu-239 & $3.476 \mathrm{E}+08$ & 168 & $\mathrm{BEA}-\mathrm{CFA}$ \\
\hline Pu-239 & $3.476 \mathrm{E}+08$ & 168 & BEA-EFS \\
\hline Pu-239 & $3.476 \mathrm{E}+08$ & 168 & BEA-CRATER \\
\hline Pu-239 & $3.476 \mathrm{E}+08$ & 168 & ESER-VAN \\
\hline Pu-239 & $3.476 \mathrm{E}+08$ & 168 & ESER-CRA \\
\hline Pu-239 & $3.476 \mathrm{E}+08$ & 168 & ESER-ARC \\
\hline $\mathrm{Pu}-239$ & $3.476 \mathrm{E}+08$ & 168 & ESER-SUG \\
\hline Pu-239 & $3.476 \mathrm{E}+08$ & 168 & ESER-IDA \\
\hline Pu-239 & $3.476 \mathrm{E}+08$ & 168 & ESER-DUB \\
\hline Pu-239 & $3.476 \mathrm{E}+08$ & 168 & ESER-MON \\
\hline Pu-239 & $3.476 \mathrm{E}+08$ & 168 & ESER-EFS \\
\hline $\mathrm{Pu}-239$ & $3.476 \mathrm{E}+08$ & 168 & ESER-ATO \\
\hline Pu-239 & $3.476 \mathrm{E}+08$ & 168 & ESER-MOU \\
\hline Pu-239 & $3.476 \mathrm{E}+08$ & 168 & ESER-BLU \\
\hline Pu-239 & $3.476 \mathrm{E}+08$ & 168 & ESER-TER \\
\hline Pu-239 & $3.476 \mathrm{E}+08$ & 168 & ESER-HOW \\
\hline Pu-239 & $3.476 \mathrm{E}+08$ & 168 & RWMCS \\
\hline Pu-239 & $3.476 \mathrm{E}+08$ & 168 & $\mathrm{MFCN}$ \\
\hline Pu-239 & $3.476 \mathrm{E}+08$ & 168 & MFCGS \\
\hline Pu-239 & $3.476 \mathrm{E}+08$ & 168 & Onsite Station \\
\hline Pu-239 & $3.476 \mathrm{E}+08$ & 168 & Offsité Station \\
\hline $\mathrm{Sr}-90$ & $1.434 \mathrm{E}+10$ & 168 & BEA-TRA \\
\hline $\mathrm{Sr}-90$ & $1.434 \mathrm{E}+10$ & 168 & $\mathrm{BEA}-\mathrm{CPP}$ \\
\hline $\mathrm{Sr}-90$ & $1.434 \mathrm{E}+10$ & 168 & BEA-RWMC \\
\hline $\mathrm{Sr}-90$ & $1.434 \mathrm{E}+10$ & 168 & BEA-VAN \\
\hline Sr -90 & $1.434 \mathrm{E}+10$ & 168 & BEA-IRC \\
\hline Sr -90 & $1.434 \mathrm{E}+10$ & 168 & BEA-BLKFT \\
\hline Sr -90 & $1.434 \mathrm{E}+10$ & 168 & BEA-SMC \\
\hline $\mathrm{Sr}-90$ & $1.434 \mathrm{E}+10$ & 168 & BEA-GATE \\
\hline $\mathrm{Sr}-90$ & $1.434 \mathrm{E}+10$ & 168 & BEA-REST \\
\hline $\mathrm{Sr}-90$ & $1.434 \mathrm{E}+10$ & 168 & $\mathrm{BEA}-\mathrm{IF}$ \\
\hline Sr-90 & $1.434 \mathrm{E}+10$ & 168 & $\mathrm{BEA}-\mathrm{NRF}$ \\
\hline $\mathrm{Sr}-90$ & $1.434 \mathrm{E}+10$ & 168 & BEA-RTC \\
\hline $\operatorname{Sr}-90$ & $1.434 \mathrm{E}+10$ & 168 & BEA-EBR \\
\hline $\mathrm{Sr}-90$ & $1.434 \mathrm{E}+10$ & 168 & BEA-MFC \\
\hline $\mathrm{Sr}-90$ & $1.434 \mathrm{E}+10$ & 168 & BEA-SUGAR \\
\hline $\mathrm{Sr}-90$ & $1.434 \mathrm{E}+10$ & 168 & BEA-INTEC \\
\hline $\mathrm{Sr}-90$ & $1.434 \mathrm{E}+10$ & 168 & $\mathrm{BEA}-\mathrm{CFA}$ \\
\hline Sr -90 & $1.434 \mathrm{E}+10$ & 168 & BEA-EFS \\
\hline $\mathrm{Sr}-90$ & $1.434 \mathrm{E}+10$ & 168 & BEA-CRATER \\
\hline $\mathrm{Sr}-90$ & $1.434 \mathrm{E}+10$ & 168 & ESER-VAN \\
\hline $\mathrm{Sr}-90$ & $1.434 \mathrm{E}+10$ & 168 & ESER-CRA \\
\hline $\mathrm{Sr}-90$ & $1.434 \mathrm{E}+10$ & 168 & ESER-ARC \\
\hline $\mathrm{Sr}-90$ & $1.434 \mathrm{E}+10$ & 168 & ESER-SUG \\
\hline $\mathrm{Sr}-90$ & $1.434 \mathrm{E}+10$ & 168 & ESER-IDA \\
\hline
\end{tabular}

C-31 


\begin{tabular}{|c|c|c|c|c|c|}
\hline Sr -90 & $1.434 \mathrm{E}+10$ & 168 & ESER-DUB & $0.000 \mathrm{E}+00$ & \\
\hline $\mathrm{Sr}-90$ & $1.434 \mathrm{E}+10$ & 168 & ESER-MON & $0.000 \mathrm{E}+00$ & \\
\hline Sr -90 & $1.434 \mathrm{E}+10$ & 168 & ESER-EFS & $9.802 \mathrm{E}-01$ & \\
\hline $\mathrm{Sr}-90$ & $1.434 \mathrm{E}+10$ & 168 & ESER-ATO & $5.934 \mathrm{E}-01$ & \\
\hline $\mathrm{Sr}-90$ & $1.434 \mathrm{E}+10$ & 168 & ESER-MOU & $0.000 \mathrm{E}+00$ & \\
\hline $\mathrm{Sr}-90$ & $1.434 \mathrm{E}+10$ & 168 & ESER-BLU & $0.000 \mathrm{E}+00$ & \\
\hline $\mathrm{Sr}-90$ & $1.434 \mathrm{E}+10$ & 168 & ESER-TER & $5.587 \mathrm{E}-03$ & \\
\hline $\mathrm{Sr}-90$ & $1.434 \mathrm{E}+10$ & 168 & ESER-HOW & $6.402 \mathrm{E}-03$ & \\
\hline $\mathrm{Sr}-90$ & $1.434 \mathrm{E}+10$ & 168 & RWMCS & $1.000 \mathrm{E}+00$ & \\
\hline $\mathrm{Sr}-90$ & $1.434 \mathrm{E}+10$ & 168 & $\mathrm{MFCN}$ & $2.330 \mathrm{E}-01$ & \\
\hline $\mathrm{Sr}-90$ & $1.434 \mathrm{E}+10$ & 168 & MFCGS & $2.387 \mathrm{E}-01$ & \\
\hline $\mathrm{Sr}-90$ & $1.434 \mathrm{E}+10$ & 168 & Onsite_Station & $1.000 \mathrm{E}+00$ & $4.431 \mathrm{E}-01$ \\
\hline $\mathrm{Sr}-90$ & $1.434 \mathrm{E}+10$ & 168 & Offsité_Station & $0.000 \mathrm{E}+00$ & $0.000 \mathrm{E}+00$ \\
\hline I-131 & $9.559 \mathrm{E}+10$ & 168 & BEA-TRA & $1.000 \mathrm{E}+00$ & \\
\hline I-131 & $9.559 \mathrm{E}+10$ & 168 & $\mathrm{BEA}-\mathrm{CPP}$ & $1.000 \mathrm{E}+00$ & \\
\hline$I-131$ & $9.559 \mathrm{E}+10$ & 168 & BEA-RWMC & $1.000 \mathrm{E}+00$ & \\
\hline I-131 & $9.559 \mathrm{E}+10$ & 168 & BEA-VAN & $1.000 \mathrm{E}+00$ & \\
\hline I-131 & $9.559 \mathrm{E}+10$ & 168 & $B E A-I R C$ & $4.086 \mathrm{E}-02$ & \\
\hline I-131 & $9.559 \mathrm{E}+10$ & 168 & BEA-BLKFT & $1.212 \mathrm{E}-01$ & \\
\hline$I-131$ & $9.559 \mathrm{E}+10$ & 168 & BEA-SMC & $7.859 \mathrm{E}-01$ & \\
\hline I-131 & $9.559 \mathrm{E}+10$ & 168 & BEA-GATE & $9.033 \mathrm{E}-01$ & \\
\hline$I-131$ & $9.559 \mathrm{E}+10$ & 168 & $\mathrm{BEA}-\mathrm{REST}$ & $1.000 \mathrm{E}+00$ & \\
\hline I-131 & $9.559 \mathrm{E}+10$ & 168 & $B E A-I F$ & $4.551 \mathrm{E}-02$ & \\
\hline I-131 & $9.559 \mathrm{E}+10$ & 168 & $\mathrm{BEA}-\mathrm{NRF}$ & $1.000 \mathrm{E}+00$ & \\
\hline$I-131$ & $9.559 \mathrm{E}+10$ & 168 & BEA-RTC & $1.000 \mathrm{E}+00$ & \\
\hline I-131 & $9.559 \mathrm{E}+10$ & 168 & BEA-EBR & $1.000 \mathrm{E}+00$ & \\
\hline$I-131$ & $9.559 \mathrm{E}+10$ & 168 & $\mathrm{BEA}-\mathrm{MFC}$ & $8.803 \mathrm{E}-01$ & \\
\hline$I-131$ & $9.559 \mathrm{E}+10$ & 168 & BEA-SUGAR & $3.411 \mathrm{E}-02$ & \\
\hline I-131 & $9.559 \mathrm{E}+10$ & 168 & BEA-INTEC & $1.000 \mathrm{E}+00$ & \\
\hline I-131 & $9.559 \mathrm{E}+10$ & 168 & $\mathrm{BEA}-\mathrm{CFA}$ & $1.000 \mathrm{E}+00$ & \\
\hline I-131 & $9.559 \mathrm{E}+10$ & 168 & BEA-EFS & $1.000 \mathrm{E}+00$ & \\
\hline I-131 & $9.559 \mathrm{E}+10$ & 168 & BEA-CRATER & $5.180 \mathrm{E}-02$ & \\
\hline I-131 & $9.559 \mathrm{E}+10$ & 168 & ESER-VAN & $1.000 \mathrm{E}+00$ & \\
\hline I-131 & $9.559 \mathrm{E}+10$ & 168 & ESER-CRA & $5.180 \mathrm{E}-02$ & \\
\hline I-131 & $9.559 \mathrm{E}+10$ & 168 & ESER-ARC & $3.636 \mathrm{E}-01$ & \\
\hline$I-131$ & $9.559 \mathrm{E}+10$ & 168 & ESER-SUG & $3.411 \mathrm{E}-02$ & \\
\hline I-131 & $9.559 \mathrm{E}+10$ & 168 & ESER-IDA & $4.551 \mathrm{E}-02$ & \\
\hline I-131 & $9.559 \mathrm{E}+10$ & 168 & ESER-DUB & $1.578 \mathrm{E}-01$ & \\
\hline$I-131$ & $9.559 \mathrm{E}+10$ & 168 & ESER-MON & $4.254 \mathrm{E}-01$ & \\
\hline$I-131$ & $9.559 \mathrm{E}+10$ & 168 & ESER-EFS & $1.000 \mathrm{E}+00$ & \\
\hline$I-131$ & $9.559 \mathrm{E}+10$ & 168 & ESER-ATO & $9.129 \mathrm{E}-01$ & \\
\hline I-131 & $9.559 \mathrm{E}+10$ & 168 & ESER-MOU & $1.213 \mathrm{E}-01$ & \\
\hline I-131 & $9.559 \mathrm{E}+10$ & 168 & ESER-BLU & $1.776 \mathrm{E}-01$ & \\
\hline I-131 & $9.559 \mathrm{E}+10$ & 168 & ESER-TER & $6.619 \mathrm{E}-01$ & \\
\hline$I-131$ & $9.559 \mathrm{E}+10$ & 168 & ESER-HOW & $6.380 \mathrm{E}-01$ & \\
\hline I-131 & $9.559 \mathrm{E}+10$ & 168 & RWMCS & $1.000 \mathrm{E}+00$ & \\
\hline$I-131$ & $9.559 \mathrm{E}+10$ & 168 & $\mathrm{MFCN}$ & $8.767 \mathrm{E}-01$ & \\
\hline$I-131$ & $9.559 \mathrm{E}+10$ & 168 & MFCGS & $8.736 \mathrm{E}-01$ & \\
\hline I-131 & $9.559 \mathrm{E}+10$ & 168 & Onsite Station & $1.000 \mathrm{E}+00$ & $6.344 \mathrm{E}-01$ \\
\hline I-131 & $9.559 \mathrm{E}+10$ & 168 & Offsité_station & $0.000 \mathrm{E}+00$ & $0.000 \mathrm{E}+00$ \\
\hline
\end{tabular}

RESIDENT SCENARIO, EXISTING NETWORK, OPTIMIZED FOR TAN-679



Date: 05/16/2015 Time: 21:27:15.711

Input File: freqd.par

START OF PARAMETER DEFINITION FILE

FreqD.f95 - Evaluation of existing network for 168-hr release yielding 1 mrem/yr Data File:../../.TICSALL/TAN-679_combine.txt

\begin{tabular}{lcc} 
BEA-TRA & 3.398 & 168 \\
BEA-CPP & 3.398 & 168 \\
BEA-RWMC & 3.398 & 168 \\
BEA-VAN & 3.398 & 168 \\
BEA-IRC & 3.398 & 168 \\
BEA-BLKFT & 3.398 & 168 \\
BEA-SMC & 3.398 & 168 \\
BEA-GATE & 3.398 & 168 \\
BEA-ARA & 3.398 & 168 \\
BEA-REST & 3.398 & 168 \\
BEA-IF & 3.398 & 168 \\
BEA-NRF & 3.398 & 168 \\
BEA-RTC & 3.398 & 168 \\
BEA-EBR & 3.398 & 168 \\
BEA-MFC & 3.398 & 168 \\
BEA-SUGAR & 3.398 & 168 \\
BEA-PBF & 3.398 & 168 \\
BEA-INTEC & 3.398 & 168 \\
BEA-CFA & 3.398 & 168 \\
BEA-EFS & 3.398 & 168 \\
BEA-CRATER & 3.398 \\
& \multicolumn{3}{c}{168}
\end{tabular}

BEA-CRATER $\quad 3.398 \quad 168 \quad 1$

\begin{abstract}
sampname, flowr, rtime, onsite, incsamp sampname, flowr, rtime, onsite, incsamp sampname, flowr, rtime, onsite, incsamp sampname, flowr, rtime, onsite, incsamp sampname, flowr, rtime, onsite, incsamp sampname, flowr, rtime, onsite, incsamp sampname, flowr, rtime, onsite, incsamp sampname, flowr, rtime, onsite, incsamp sampname, flowr, rtime, onsite, incsamp sampname, flowr, rtime, onsite, incsamp sampname, flowr, rtime, onsite, incsamp samphame, flowr, rtime, onsite, incsamp sampname, flowr, rtime, onsite, incsamp sampname, flowr, rtime, onsite, incsamp sampname, flowr, rtime, onsite, incsamp
sampname, flowr, rtime, onsite, incsamp sampname, flowr, rtime, onsite, incsamp sampname, flowr, rtime, onsite, incsamp sampname, flowr, rtime, onsite, incsamp sampname, flowr, rtime, onsite, incsamp sampname, flowr, rtime, onsite, incsamp sampname, flowr, rtime, onsite, incsamp
\end{abstract}




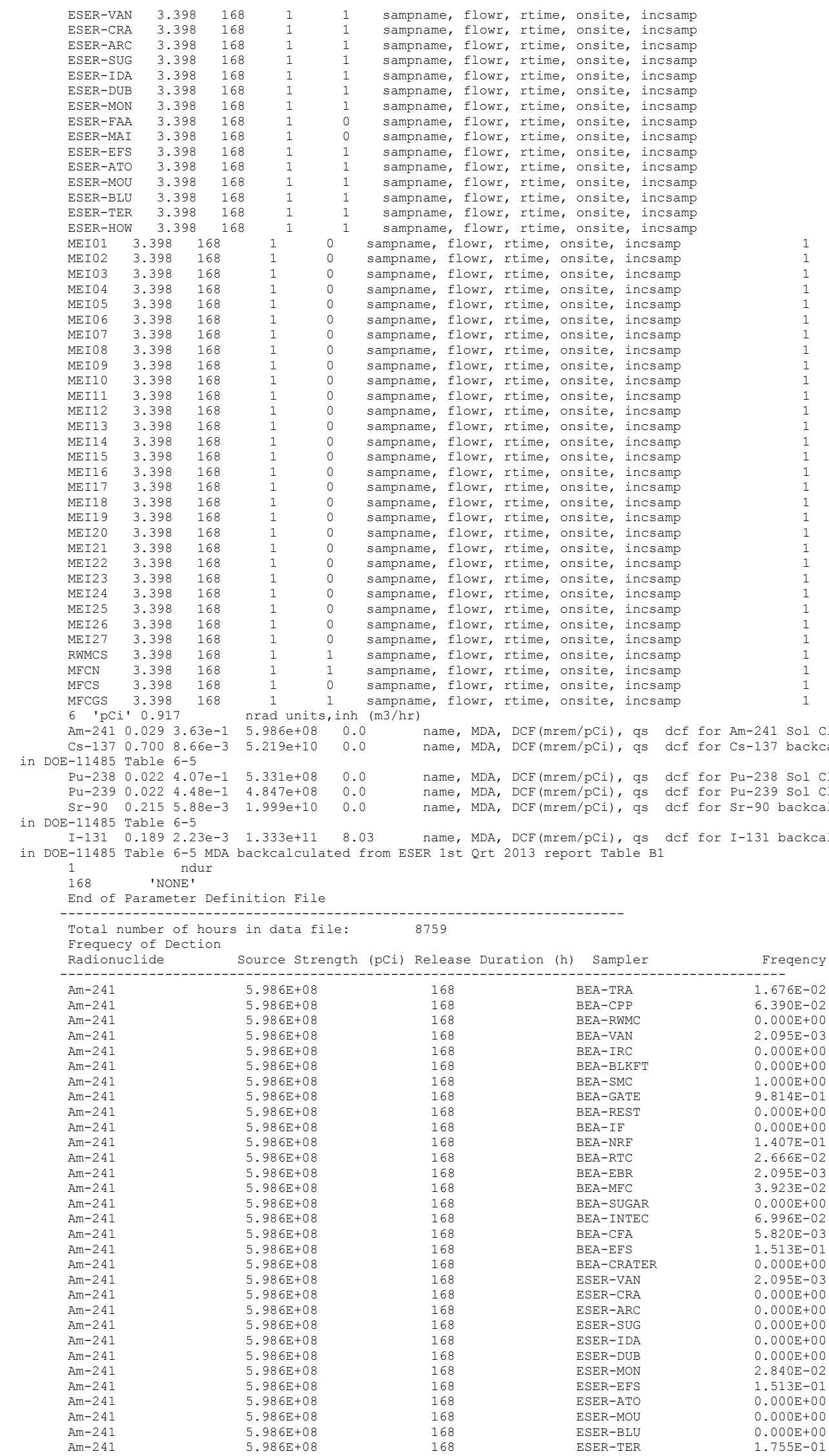




\begin{tabular}{|c|c|c|c|}
\hline Am-241 & $5.986 \mathrm{E}+08$ & 168 & ESER-HOW \\
\hline$A m-241$ & $5.986 \mathrm{E}+08$ & 168 & RWMCS \\
\hline Am-241 & $5.986 \mathrm{E}+08$ & 168 & $\mathrm{MFCN}$ \\
\hline$A m-241$ & $5.986 \mathrm{E}+08$ & 168 & MFCGS \\
\hline$A m-241$ & $5.986 \mathrm{E}+08$ & 168 & Onsite_Station \\
\hline$A m-241$ & $5.986 \mathrm{E}+08$ & 168 & Offsité_Station \\
\hline Cs -137 & $5.219 \mathrm{E}+10$ & 168 & BEA-TRA \\
\hline Cs -137 & $5.219 \mathrm{E}+10$ & 168 & $\mathrm{BEA}-\mathrm{CPP}$ \\
\hline Cs -137 & $5.219 \mathrm{E}+10$ & 168 & BEA-RWMC \\
\hline Cs -137 & $5.219 \mathrm{E}+10$ & 168 & BEA-VAN \\
\hline Cs -137 & $5.219 \mathrm{E}+10$ & 168 & $B E A-I R C$ \\
\hline Cs -137 & $5.219 \mathrm{E}+10$ & 168 & BEA-BLKFT \\
\hline Cs -137 & $5.219 \mathrm{E}+10$ & 168 & BEA-SMC \\
\hline Cs -137 & $5.219 \mathrm{E}+10$ & 168 & BEA-GATE \\
\hline Cs -137 & $5.219 \mathrm{E}+10$ & 168 & BEA-REST \\
\hline Cs -137 & $5.219 \mathrm{E}+10$ & 168 & $\mathrm{BEA}-\mathrm{IF}$ \\
\hline Cs -137 & $5.219 \mathrm{E}+10$ & 168 & $\mathrm{BEA}-\mathrm{NRF}$ \\
\hline Cs -137 & $5.219 \mathrm{E}+10$ & 168 & $\mathrm{BEA}-\mathrm{RTC}$ \\
\hline Cs -137 & $5.219 \mathrm{E}+10$ & 168 & $\mathrm{BEA}-\mathrm{EBR}$ \\
\hline Cs -137 & $5.219 \mathrm{E}+10$ & 168 & $\mathrm{BEA}-\mathrm{MFC}$ \\
\hline Cs -137 & $5.219 \mathrm{E}+10$ & 168 & BEA-SUGAR \\
\hline Cs -137 & $5.219 \mathrm{E}+10$ & 168 & BEA-INTEC \\
\hline Cs -137 & $5.219 \mathrm{E}+10$ & 168 & $\mathrm{BEA}-\mathrm{CFA}$ \\
\hline Cs -137 & $5.219 \mathrm{E}+10$ & 168 & $B E A-E F S$ \\
\hline Cs -137 & $5.219 \mathrm{E}+10$ & 168 & BEA-CRATER \\
\hline Cs -137 & $5.219 \mathrm{E}+10$ & 168 & ESER-VAN \\
\hline $\mathrm{Cs}-137$ & $5.219 \mathrm{E}+10$ & 168 & ESER-CRA \\
\hline Cs -137 & $5.219 \mathrm{E}+10$ & 168 & ESER-ARC \\
\hline Cs -137 & $5.219 \mathrm{E}+10$ & 168 & ESER-SUG \\
\hline Cs -137 & $5.219 \mathrm{E}+10$ & 168 & ESER-IDA \\
\hline Cs -137 & $5.219 \mathrm{E}+10$ & 168 & ESER-DUB \\
\hline Cs -137 & $5.219 \mathrm{E}+10$ & 168 & ESER-MON \\
\hline Cs -137 & $5.219 \mathrm{E}+10$ & 168 & ESER-EFS \\
\hline $\mathrm{Cs}-137$ & $5.219 \mathrm{E}+10$ & 168 & ESER-ATO \\
\hline Cs -137 & $5.219 \mathrm{E}+10$ & 168 & ESER-MOU \\
\hline Cs -137 & $5.219 \mathrm{E}+10$ & 168 & ESER-BLU \\
\hline Cs -137 & $5.219 \mathrm{E}+10$ & 168 & ESER-TER \\
\hline $\mathrm{Cs}-137$ & $5.219 \mathrm{E}+10$ & 168 & ESER-HOW \\
\hline $\mathrm{Cs}-137$ & $5.219 \mathrm{E}+10$ & 168 & RWMCS \\
\hline $\mathrm{Cs}-137$ & $5.219 \mathrm{E}+10$ & 168 & $\mathrm{MFCN}$ \\
\hline Cs -137 & $5.219 \mathrm{E}+10$ & 168 & MFCGS \\
\hline Cs -137 & $5.219 \mathrm{E}+10$ & 168 & Onsite_Station \\
\hline $\mathrm{Cs}-137$ & $5.219 \mathrm{E}+10$ & 168 & Offsite Station \\
\hline $\mathrm{Pu}-238$ & $5.331 \mathrm{E}+08$ & 168 & $\mathrm{BEA}-\mathrm{TRA}$ \\
\hline Pu-238 & $5.331 \mathrm{E}+08$ & 168 & $\mathrm{BEA}-\mathrm{CPP}$ \\
\hline Pu-238 & $5.331 \mathrm{E}+08$ & 168 & BEA-RWMC \\
\hline $\mathrm{Pu}-238$ & $5.331 \mathrm{E}+08$ & 168 & BEA-VAN \\
\hline Pu-238 & $5.331 \mathrm{E}+08$ & 168 & BEA-IRC \\
\hline Pu-238 & $5.331 \mathrm{E}+08$ & 168 & BEA-BLKFT \\
\hline Pu-238 & $5.331 \mathrm{E}+08$ & 168 & BEA-SMC \\
\hline Pu-238 & $5.331 \mathrm{E}+08$ & 168 & BEA-GATE \\
\hline $\mathrm{Pu}-238$ & $5.331 \mathrm{E}+08$ & 168 & BEA-REST \\
\hline Pu-238 & $5.331 \mathrm{E}+08$ & 168 & $\mathrm{BEA}-\mathrm{IF}$ \\
\hline $\mathrm{Pu}-238$ & $5.331 \mathrm{E}+08$ & 168 & $\mathrm{BEA}-\mathrm{NRF}$ \\
\hline Pu-238 & $5.331 \mathrm{E}+08$ & 168 & BEA-RTC \\
\hline $\mathrm{Pu}-238$ & $5.331 \mathrm{E}+08$ & 168 & $\mathrm{BEA}-\mathrm{EBR}$ \\
\hline $\mathrm{Pu}-238$ & $5.331 \mathrm{E}+08$ & 168 & BEA-MFC \\
\hline Pu-238 & $5.331 \mathrm{E}+08$ & 168 & BEA-SUGAR \\
\hline Pu-238 & $5.331 \mathrm{E}+08$ & 168 & BEA-INTEC \\
\hline $\mathrm{Pu}-238$ & $5.331 \mathrm{E}+08$ & 168 & $\mathrm{BEA}-\mathrm{CFA}$ \\
\hline $\mathrm{Pu}-238$ & $5.331 \mathrm{E}+08$ & 168 & $\mathrm{BEA}-\mathrm{EFS}$ \\
\hline Pu-238 & $5.331 \mathrm{E}+08$ & 168 & BEA-CRATER \\
\hline Pu-238 & $5.331 \mathrm{E}+08$ & 168 & ESER-VAN \\
\hline Pu-238 & $5.331 \mathrm{E}+08$ & 168 & ESER-CRA \\
\hline Pu-238 & $5.331 \mathrm{E}+08$ & 168 & ESER-ARC \\
\hline Pu-238 & $5.331 \mathrm{E}+08$ & 168 & ESER-SUG \\
\hline $\mathrm{Pu}-238$ & $5.331 \mathrm{E}+08$ & 168 & ESER-IDA \\
\hline $\mathrm{Pu}-238$ & $5.331 \mathrm{E}+08$ & 168 & ESER-DUB \\
\hline Pu-238 & $5.331 \mathrm{E}+08$ & 168 & ESER-MON \\
\hline Pu-238 & $5.331 \mathrm{E}+08$ & 168 & ESER-EFS \\
\hline Pu-238 & $5.331 \mathrm{E}+08$ & 168 & ESER-ATO \\
\hline $\mathrm{Pu}-238$ & $5.331 \mathrm{E}+08$ & 168 & ESER-MOU \\
\hline $\mathrm{Pu}-238$ & $5.331 \mathrm{E}+08$ & 168 & ESER-BLU \\
\hline $\mathrm{Pu}-238$ & $5.331 \mathrm{E}+08$ & 168 & ESER-TER \\
\hline $\mathrm{Pu}-238$ & $5.331 \mathrm{E}+08$ & 168 & ESER-HOW \\
\hline $\mathrm{Pu}-238$ & $5.331 \mathrm{E}+08$ & 168 & RWMCS \\
\hline Pu-238 & $5.331 \mathrm{E}+08$ & 168 & $\mathrm{MFCN}$ \\
\hline $\mathrm{Pu}-238$ & $5.331 \mathrm{E}+08$ & 168 & MFCGS \\
\hline $\mathrm{Pu}-238$ & $5.331 \mathrm{E}+08$ & 168 & Onsite Station \\
\hline Pu-238 & $5.331 \mathrm{E}+08$ & 168 & offsité_Station \\
\hline $\mathrm{Pu}-239$ & $4.847 \mathrm{E}+08$ & 168 & $\mathrm{BEA}-\mathrm{TRA}$ \\
\hline $\mathrm{Pu}-239$ & $4.847 \mathrm{E}+08$ & 168 & $\mathrm{BEA}-\mathrm{CPP}$ \\
\hline $\mathrm{Pu}-239$ & $4.847 \mathrm{E}+08$ & 168 & BEA-RWMC \\
\hline Pu-239 & $4.847 \mathrm{E}+08$ & 168 & BEA-VAN \\
\hline $\mathrm{Pu}-239$ & $4.847 \mathrm{E}+08$ & 168 & $B E A-I R C$ \\
\hline $\mathrm{Pu}-239$ & $4.847 \mathrm{E}+08$ & 168 & BEA-BLKFT \\
\hline $\mathrm{Pu}-239$ & $4.847 \mathrm{E}+08$ & 168 & BEA-SMC \\
\hline $\mathrm{Pu}-239$ & $4.847 \mathrm{E}+08$ & 168 & BEA-GATE \\
\hline $\mathrm{Pu}-239$ & $4.847 \mathrm{E}+08$ & 168 & BEA-REST \\
\hline $\mathrm{Pu}-239$ & $4.847 \mathrm{E}+08$ & 168 & $\mathrm{BEA}-\mathrm{IF}$ \\
\hline $\mathrm{Pu}-239$ & $4.847 \mathrm{E}+08$ & 168 & BEA-NRF \\
\hline $\mathrm{Pu}-239$ & $4.847 \mathrm{E}+08$ & 168 & BEA-RTC \\
\hline $\mathrm{Pu}-239$ & $4.847 \mathrm{E}+08$ & 168 & BEA-EBR \\
\hline $\mathrm{Pu}-239$ & $4.847 \mathrm{E}+08$ & 168 & $\mathrm{BEA}-\mathrm{MFC}$ \\
\hline Pu-239 & $4.847 \mathrm{E}+08$ & 168 & BEA-SUGAR \\
\hline
\end{tabular}




\begin{tabular}{|c|c|c|c|}
\hline Pu-239 & $4.847 \mathrm{E}+08$ & 168 & BEA-INTEC \\
\hline $\mathrm{Pu}-239$ & $4.847 \mathrm{E}+08$ & 168 & $\mathrm{BEA}-\mathrm{CFA}$ \\
\hline Pu-239 & $4.847 \mathrm{E}+08$ & 168 & BEA-EFS \\
\hline Pu-239 & $4.847 \mathrm{E}+08$ & 168 & BEA-CRATER \\
\hline Pu-239 & $4.847 \mathrm{E}+08$ & 168 & ESER-VAN \\
\hline Pu-239 & $4.847 \mathrm{E}+08$ & 168 & ESER-CRA \\
\hline Pu-239 & $4.847 \mathrm{E}+08$ & 168 & ESER-ARC \\
\hline Pu-239 & $4.847 \mathrm{E}+08$ & 168 & ESER-SUG \\
\hline Pu-239 & $4.847 \mathrm{E}+08$ & 168 & ESER-IDA \\
\hline Pu-239 & $4.847 \mathrm{E}+08$ & 168 & ESER-DUB \\
\hline Pu-239 & $4.847 \mathrm{E}+08$ & 168 & ESER-MON \\
\hline Pu-239 & $4.847 \mathrm{E}+08$ & 168 & ESER-EFS \\
\hline Pu-239 & $4.847 \mathrm{E}+08$ & 168 & ESER-ATO \\
\hline Pu-239 & $4.847 \mathrm{E}+08$ & 168 & ESER-MOU \\
\hline Pu-239 & $4.847 \mathrm{E}+08$ & 168 & ESER-BLU \\
\hline Pu-239 & $4.847 \mathrm{E}+08$ & 168 & ESER-TER \\
\hline Pu-239 & $4.847 \mathrm{E}+08$ & 168 & ESER-HOW \\
\hline Pu-239 & $4.847 \mathrm{E}+08$ & 168 & RWMCS \\
\hline Pu-239 & $4.847 \mathrm{E}+08$ & 168 & $\mathrm{MFCN}$ \\
\hline Pu-239 & $4.847 \mathrm{E}+08$ & 168 & MFCGS \\
\hline Pu-239 & $4.847 \mathrm{E}+08$ & 168 & Onsite Station \\
\hline Pu-239 & $4.847 \mathrm{E}+08$ & 168 & Offsitè_Station \\
\hline Sr -90 & $1.999 \mathrm{E}+10$ & 168 & BEA-TRA \\
\hline Sr -90 & $1.999 \mathrm{E}+10$ & 168 & $\mathrm{BEA}-\mathrm{CPP}$ \\
\hline $\mathrm{Sr}-90$ & $1.999 \mathrm{E}+10$ & 168 & BEA-RWMC \\
\hline $\mathrm{Sr}-90$ & $1.999 \mathrm{E}+10$ & 168 & BEA-VAN \\
\hline $\mathrm{Sr}-90$ & $1.999 \mathrm{E}+10$ & 168 & BEA-IRC \\
\hline $\mathrm{Sr}-90$ & $1.999 \mathrm{E}+10$ & 168 & BEA-BLKFT \\
\hline $\mathrm{Sr}-90$ & $1.999 \mathrm{E}+10$ & 168 & BEA-SMC \\
\hline $\mathrm{Sr}-90$ & $1.999 \mathrm{E}+10$ & 168 & BEA-GATE \\
\hline $\mathrm{Sr}-90$ & $1.999 \mathrm{E}+10$ & 168 & BEA-REST \\
\hline $\mathrm{Sr}-90$ & $1.999 \mathrm{E}+10$ & 168 & $\mathrm{BEA}-\mathrm{IF}$ \\
\hline $\mathrm{Sr}-90$ & $1.999 \mathrm{E}+10$ & 168 & $\mathrm{BEA}-\mathrm{NRF}$ \\
\hline $\mathrm{Sr}-90$ & $1.999 \mathrm{E}+10$ & 168 & BEA-RTC \\
\hline $\mathrm{Sr}-90$ & $1.999 \mathrm{E}+10$ & 168 & $B E A-E B R$ \\
\hline Sr -90 & $1.999 \mathrm{E}+10$ & 168 & BEA-MFC \\
\hline $\mathrm{Sr}-90$ & $1.999 \mathrm{E}+10$ & 168 & BEA-SUGAR \\
\hline $\mathrm{Sr}-90$ & $1.999 \mathrm{E}+10$ & 168 & BEA-INTEC \\
\hline $\mathrm{Sr}-90$ & $1.999 \mathrm{E}+10$ & 168 & $\mathrm{BEA}-\mathrm{CFA}$ \\
\hline $\mathrm{Sr}-90$ & $1.999 \mathrm{E}+10$ & 168 & BEA-EFS \\
\hline $\mathrm{Sr}-90$ & $1.999 \mathrm{E}+10$ & 168 & BEA-CRATER \\
\hline Sr-90 & $1.999 \mathrm{E}+10$ & 168 & ESER-VAN \\
\hline $\mathrm{Sr}-90$ & $1.999 \mathrm{E}+10$ & 168 & ESER-CRA \\
\hline $\mathrm{Sr}-90$ & $1.999 \mathrm{E}+10$ & 168 & ESER-ARC \\
\hline $\mathrm{Sr}-90$ & $1.999 \mathrm{E}+10$ & 168 & ESER-SUG \\
\hline $\mathrm{Sr}-90$ & $1.999 \mathrm{E}+10$ & 168 & ESER-IDA \\
\hline $\mathrm{Sr}-90$ & $1.999 \mathrm{E}+10$ & 168 & ESER-DUB \\
\hline $\mathrm{Sr}-90$ & $1.999 \mathrm{E}+10$ & 168 & ESER-MON \\
\hline $\mathrm{Sr}-90$ & $1.999 \mathrm{E}+10$ & 168 & ESER-EFS \\
\hline Sr -90 & $1.999 \mathrm{E}+10$ & 168 & ESER-ATO \\
\hline $\mathrm{Sr}-90$ & $1.999 \mathrm{E}+10$ & 168 & ESER-MOU \\
\hline $\mathrm{Sr}-90$ & $1.999 \mathrm{E}+10$ & 168 & ESER-BLU \\
\hline $\mathrm{Sr}-90$ & $1.999 \mathrm{E}+10$ & 168 & ESER-TER \\
\hline $\mathrm{Sr}-90$ & $1.999 \mathrm{E}+10$ & 168 & ESER-HOW \\
\hline $\mathrm{Sr}-90$ & $1.999 \mathrm{E}+10$ & 168 & RWMCS \\
\hline $\mathrm{Sr}-90$ & $1.999 \mathrm{E}+10$ & 168 & $\mathrm{MFCN}$ \\
\hline $\mathrm{Sr}-90$ & $1.999 \mathrm{E}+10$ & 168 & MFCGS \\
\hline $\mathrm{Sr}-90$ & $1.999 \mathrm{E}+10$ & 168 & Onsite_station \\
\hline Sr -90 & $1.999 \mathrm{E}+10$ & 168 & Offsitē_station \\
\hline I-131 & $1.333 \mathrm{E}+11$ & 168 & BEA-TRA \\
\hline$I-131$ & $1.333 \mathrm{E}+11$ & 168 & $\mathrm{BEA}-\mathrm{CPP}$ \\
\hline I-131 & $1.333 \mathrm{E}+11$ & 168 & BEA-RWMC \\
\hline$I-131$ & $1.333 \mathrm{E}+11$ & 168 & BEA-VAN \\
\hline I-131 & $1.333 \mathrm{E}+11$ & 168 & $B E A-I R C$ \\
\hline I-131 & $1.333 \mathrm{E}+11$ & 168 & BEA-BLKFT \\
\hline$I-131$ & $1.333 \mathrm{E}+11$ & 168 & $\mathrm{BEA}-\mathrm{SMC}$ \\
\hline I-131 & $1.333 \mathrm{E}+11$ & 168 & BEA-GATE \\
\hline$I-131$ & $1.333 \mathrm{E}+11$ & 168 & BEA-REST \\
\hline I-131 & $1.333 \mathrm{E}+11$ & 168 & $B E A-I F$ \\
\hline I-131 & $1.333 \mathrm{E}+11$ & 168 & $\mathrm{BEA}-\mathrm{NRF}$ \\
\hline I-131 & $1.333 \mathrm{E}+11$ & 168 & BEA-RTC \\
\hline I-131 & $1.333 \mathrm{E}+11$ & 168 & $\mathrm{BEA}-\mathrm{EBR}$ \\
\hline I-131 & $1.333 \mathrm{E}+11$ & 168 & $\mathrm{BEA}-\mathrm{MFC}$ \\
\hline$I-131$ & $1.333 \mathrm{E}+11$ & 168 & BEA-SUGAR \\
\hline I-131 & $1.333 \mathrm{E}+11$ & 168 & BEA-INTEC \\
\hline$I-131$ & $1.333 \mathrm{E}+11$ & 168 & $\mathrm{BEA}-\mathrm{CFA}$ \\
\hline$I-131$ & $1.333 \mathrm{E}+11$ & 168 & BEA-EFS \\
\hline I-131 & $1.333 \mathrm{E}+11$ & 168 & BEA-CRATER \\
\hline I-131 & $1.333 \mathrm{E}+11$ & 168 & ESER-VAN \\
\hline$I-131$ & $1.333 \mathrm{E}+11$ & 168 & ESER-CRA \\
\hline$I-131$ & $1.333 \mathrm{E}+11$ & 168 & ESER-ARC \\
\hline I-131 & $1.333 \mathrm{E}+11$ & 168 & ESER-SUG \\
\hline I-131 & $1.333 \mathrm{E}+11$ & 168 & ESER-IDA \\
\hline I-131 & $1.333 \mathrm{E}+11$ & 168 & ESER-DUB \\
\hline I-131 & $1.333 \mathrm{E}+11$ & 168 & ESER-MON \\
\hline I-131 & $1.333 \mathrm{E}+11$ & 168 & ESER-EFS \\
\hline I-131 & $1.333 \mathrm{E}+11$ & 168 & ESER-ATO \\
\hline I-131 & $1.333 \mathrm{E}+11$ & 168 & ESER-MOU \\
\hline I-131 & $1.333 \mathrm{E}+11$ & 168 & ESER-BLU \\
\hline I-131 & $1.333 \mathrm{E}+11$ & 168 & ESER-TER \\
\hline I-131 & $1.333 \mathrm{E}+11$ & 168 & ESER-HOW \\
\hline$I-131$ & $1.333 \mathrm{E}+11$ & 168 & RWMCS \\
\hline$I-131$ & $1.333 \mathrm{E}+11$ & 168 & $\mathrm{MFCN}$ \\
\hline I-131 & $1.333 \mathrm{E}+11$ & 168 & MFCGS \\
\hline I-131 & $1.333 \mathrm{E}+11$ & 168 & Onsite_Station \\
\hline
\end{tabular}






Date: 05/16/2015 Time: 21:27:40.296

Input File: freqd.par

START OF PARAMETER DEFINITION FILE

FreqD.f95 - Evaluation of existing network for 168-hr release yielding 1 mrem/yr Data File:../././TICSALL/TRA-770_combine.txt

67

$\begin{array}{llllll}\text { BEA-TRA } & 3.398 & 168 & 1 & 1 & \text { sampname, flowr, rtime, onsite, incsamp }\end{array}$ $\begin{array}{lll}B E A-C P P & 3.398 & 168\end{array}$

BEA-RWMC $3.398 \quad 168$

$\begin{array}{lll}3.398 & 168\end{array}$

BEA-IRC $\quad 3.398 \quad 168$

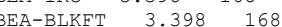

$\begin{array}{lll}\text { BEA-SMC } & 3.398 & 168\end{array}$

$\begin{array}{lll}\text { BEA-GATE } & 3.398 \quad 168\end{array}$

BEA-ARA $3.398 \quad 168$

$\begin{array}{lll}\text { BEA-REST } & 3.398 & 168 \\ \text { BEA-IF } & 3.398 & 168\end{array}$

$\begin{array}{lll}B E A-N R F & 3.398 \quad 168\end{array}$

BEA-RTC $\quad 3.398 \quad 168$

$\begin{array}{lll}B E A-E B R & 3.398 \quad 168\end{array}$

BEA-MFC $\quad 3.398 \quad 168$

BEA-SUGAR $3.398 \quad 168$

$\begin{array}{lll}\mathrm{BEA}-\mathrm{PBF} & 3.398 & 168\end{array}$

BEA-INTEC $3.398 \quad 168$

$\begin{array}{lll}\text { BEA-CFA } & 3.398 \quad 168\end{array}$

BEA-EFS $\quad 3.398 \quad 168$

$\begin{array}{lll}\text { BEA-CRATER } & 3.398 & 168\end{array}$

$\begin{array}{lll}\text { ESER-VAN } & 3.398 & 168 \\ \text { ESER-CRA } & 3.398 & 168\end{array}$

$\begin{array}{lll}\text { ESER-CRA } & 3.398 & 168\end{array}$

$\begin{array}{lll}\text { ESER-ARC } & 3.398 & 168\end{array}$

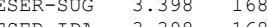

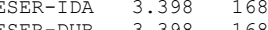

$\begin{array}{lll}\text { ESER-DUB } & 3.398 & 168 \\ \text { ESER-MON } & 3.398 & 168\end{array}$

$\begin{array}{lll} & 3.398 & 168 \\ & & \end{array}$

$\begin{array}{lll}\text { ESER-FAA } & 3.398 & 168 \\ \text { ESER-MAI } & 3.398 & 168\end{array}$

$\begin{array}{lll}\text { ESER-EFS } & 3.398 & 168\end{array}$

ESER-ATO $3.398 \quad 168$

$\begin{array}{lll}\text { ESER-MOU } & 3.398 & 168\end{array}$

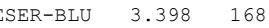

$\begin{array}{lll}\text { ESER-TER } & 3.398 & 168\end{array}$

ESER-HOW $3.398 \quad 168$

$\begin{array}{lll}\text { MEIO2 } & 3.398 & 168\end{array}$

$\begin{array}{lll}\text { MEI03 } & 3.398 & 168\end{array}$

$\begin{array}{lll}\text { MEIO3 } & 3.398 & 168 \\ \text { MEIO4 } & 3.398 & 168\end{array}$

$\begin{array}{lll}\text { MEI05 } & 3.398 \quad 168\end{array}$

MEIO $\quad 3.398 \quad 168$

$\begin{array}{lll}\mathrm{M} & 3.398 & 168\end{array}$

MEI08 $3.398 \quad 168$

$\begin{array}{lll}0 & 3.398 & 168\end{array}$

$\begin{array}{lll}M E I 10 & 3.398 & 168\end{array}$

MEI11 $3.398 \quad 168$

MEI12 $3.398 \quad 168$

$\begin{array}{lll}M E I 13 & 3.398 & 168\end{array}$

$\begin{array}{lll}\text { MEI14 } & 3.398 \quad 168\end{array}$

$\begin{array}{lll}M E I 15 & 3.398 & 168\end{array}$

$\begin{array}{lll}\text { MEI16 } & 3.398 & 168\end{array}$

MEI17 $3.398 \quad 168$

$\begin{array}{lll}\text { MEI18 } & 3.398 \quad 168\end{array}$

$\begin{array}{lll}M E I 19 & 3.398 & 168\end{array}$

$\begin{array}{lll}\text { MEI20 } & 3.398 & 168\end{array}$

$3.398 \quad 168$

$\begin{array}{lll}\text { MEI22 } & 3.398 \quad 168\end{array}$

MEI23 $3.398 \quad 168$

MEI 24 $\quad 3.398 \quad 168$

$\begin{array}{lll}3.398 & 168\end{array}$

$\begin{array}{lll} & 3.398 & 168\end{array}$

$\begin{array}{lll}\text { MEI26 } & 3.398 & 168\end{array}$

$\begin{array}{lll}\text { MEI27 } & 3.398 & 168 \\ \text { RWMCS } & 3.398 & 168\end{array}$

$\begin{array}{lll}\mathrm{MFCN} & 3.398 & 168\end{array}$

$\begin{array}{lll}M F C S & 3.398 \quad 168\end{array}$

MFCGS $3.398 \quad 168$

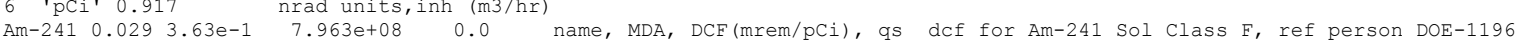
sampname, flowr, rtime, onsite, incsamp sampname, flowr, rtime, onsite, incsamp sampname, flowr, rtime, onsite, incsamp sampname, flowr, rtime, onsite, incsamp sampname, flowr, rtime, onsite, incsamp sampname, flowr, rtime, onsite, incsamp sampname, flowr, rtime, onsite, incsamp sampname, flowr, rtime, onsite, incsamp sampname, flowr, rtime, onsite, incsamp sampname, flowr, rtime, onsite, incsamp sampname, flowr, rtime, onsite, incsamp sampname, flowr, rtime, onsite, incsamp sampname, flowr, rtime, onsite, incsamp sampname, flowr, rtime, onsite, incsamp sampname, flowr, rtime, onsite, lncsamp sampname, flowr, rtime, onsite, incsanp sampnane, flowr, rtime, onsite, lncsamp sampname, flowr, rtime, onsite, lncsamp sampname, flowr, rtime, onsite, incsamp sampname, flowr, rtime, onsite, incsamp sampname, flowr, rtime, onsite, incsamp sampname, flowr, rtime, onsite, incsamp sampname, flowr, rtime, onsite, incsamp sampname, flowr, rtime, onsite, incsamp sampname, flowr, rtime, onsite, incsamp sampname, flowr, rtime, onsite, incsamp sampname, flowr, rtime, onsite, incsamp samphane, flowr, rtine, onsite, lncsamp sampname, flowr, rtime, onsite, incsamp samphame, flowr, rtime, onsite, incsamp sampname, flowr, rtime, onsite, incsamp sampname, flowr, rtime, onsite, incsamp sampname, flowr, rtime, onsite, incsamp sampname, flowr, rtime, onsite, incsamp sampname, flowr, rtime, onsite, incsamp sampname, flowr, rtime, onsite, incsamp sampname, flowr, rtime, onsite, incsamp sampname, flowr, rtime, onsite, incsamp sampname, flowr, rtime, onsite, incsamp sampnan, flowr, rtime, onsite, incsamp sampnane, flowr, rtine, onsite, incsanp sampname, flowr, rtime, onsite, lncsamp sampname, flowr, rtime, onsite, incsamp sampname, flowr, rtime, onsite, incsamp sampname, flowr, rtime, onsite, incsamp sampname, flowr, rtime, onsite, incsamp sampname, flowr, rtime, onsite, incsamp sampname, flowr, rtime, onsite, incsamp sampname, flowr, rtime, onsite, incsamp sampname, flowr, rtime, onsite, incsamp sampname, flowr, rtime, onsite, incsamp sampnam, flowr, rtime, onsite, incsamp sampname, flowr, rtime, onsite, lncsamp sampnane, flowr, rtine, onsite, incsamp sampname, flowr, rtime, onsite, incsamp sampname, flowr, rtime, onsite, lncsamp sampname, flowr, rtime, onsite, incsamp sampname, flowr, rtime, onsite, incsamp sampname, flowr, rtime, onsite, incsamp sampname, flowr, rtime, onsite, incsamp sampname, flowr, rtime, onsite, incsamp sampname, flowr, rtime, onsite, incsamp sampname, flowr, rtime, onsite, incsamp sampname, flowr, rtime, onsite, incsamp sampnam, flowr, rtime, onsite, incsanp sampnane, flowr, rtine, onsite, incsamp sampname, flowr, rtime, onsite, incsamp sampname, flowr, rtime, onsite, incsamp sampname, flowr, rtime, onsite, incsamp sampname, flowr, rtime, onsite, incsamp sampname, flowr, rtime, onsite, incsamp 
Cs-137 $0.7008 .66 \mathrm{e}-3 \quad 6.943 \mathrm{e}+10 \quad 0.0$ name, MDA, DCF(mrem/pCi), qs dcf for Cs-137 backcalculated from CAP88 as given in DOE-11485 Table $6-5$ Pu-238 $0.0224 .07 e-1 \quad 7.092 e+08 \quad 0.0 \quad$ name, MDA, DCF(mrem/pCi), qs def for Pu-238 Sol Class F, ref person DOE 1196 Pu-239 $0.0224 .48 \mathrm{e}-1 \quad 6.447 \mathrm{e}+08 \quad 0.0$ name, MDA, DCF (mrem/pCi), qs dcf for Pu-239 Sol Class F, ref person DOE 1196 Sr-90 $0.2155 .88 \mathrm{e}-3 \quad 2.660 \mathrm{e}+10 \quad 0.0 \quad$ name, MDA, DCF(mrem/pCi), qs dcf for Sr-90 backcalculated from CAP88 as given in DOE-11485 Table 6-5

I-131 $0.1892 .23 e-3 \quad 1.773 e+11 \quad 8.03$ name, MDA, DCF(mrem/pCi), qs dcf for I-131 backcalculated from CAP88 as given in DOE-11485 Table 6-5 MDA backcalculated from ESER 1st ort 2013 report Table B1

1 ndur

End of Parameter Definition File

Total number of hours in data file: 8759 Frequecy of Dection

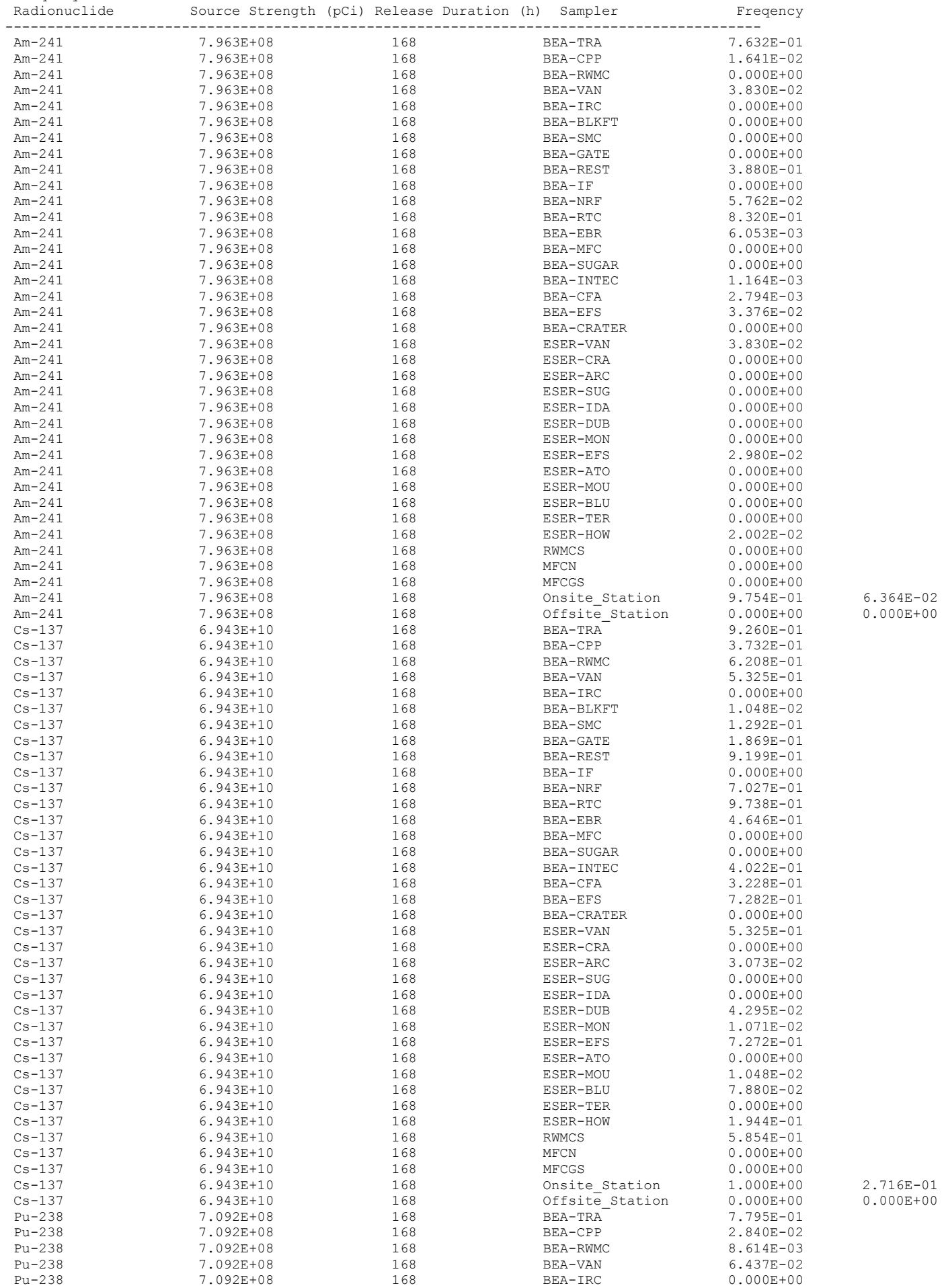




\begin{tabular}{|c|c|c|c|}
\hline Pu-238 & $7.092 \mathrm{E}+08$ & 168 & BEA-BLKFT \\
\hline Pu-238 & $7.092 \mathrm{E}+08$ & 168 & BEA-SMC \\
\hline Pu-238 & $7.092 \mathrm{E}+08$ & 168 & BEA-GATE \\
\hline Pu-238 & $7.092 \mathrm{E}+08$ & 168 & BEA-REST \\
\hline Pu-238 & $7.092 \mathrm{E}+08$ & 168 & $\mathrm{BEA}-\mathrm{IF}$ \\
\hline Pu-238 & $7.092 \mathrm{E}+08$ & 168 & $\mathrm{BEA}-\mathrm{NRF}$ \\
\hline Pu-238 & $7.092 \mathrm{E}+08$ & 168 & BEA-RTC \\
\hline Pu-238 & $7.092 \mathrm{E}+08$ & 168 & $B E A-E B R$ \\
\hline Pu-238 & $7.092 \mathrm{E}+08$ & 168 & BEA-MFC \\
\hline Pu-238 & $7.092 \mathrm{E}+08$ & 168 & BEA-SUGAR \\
\hline Pu-238 & $7.092 \mathrm{E}+08$ & 168 & BEA-INTEC \\
\hline Pu-238 & $7.092 \mathrm{E}+08$ & 168 & $\mathrm{BEA}-\mathrm{CFA}$ \\
\hline Pu-238 & $7.092 \mathrm{E}+08$ & 168 & BEA-EFS \\
\hline Pu-238 & $7.092 \mathrm{E}+08$ & 168 & BEA-CRATER \\
\hline Pu-238 & $7.092 \mathrm{E}+08$ & 168 & ESER-VAN \\
\hline Pu-238 & $7.092 \mathrm{E}+08$ & 168 & ESER-CRA \\
\hline Pu-238 & $7.092 \mathrm{E}+08$ & 168 & ESER-ARC \\
\hline Pu-238 & $7.092 \mathrm{E}+08$ & 168 & ESER-SUG \\
\hline Pu-238 & $7.092 \mathrm{E}+08$ & 168 & ESER-IDA \\
\hline Pu-238 & $7.092 \mathrm{E}+08$ & 168 & ESER-DUB \\
\hline Pu-238 & $7.092 \mathrm{E}+08$ & 168 & ESER-MON \\
\hline Pu-238 & $7.092 \mathrm{E}+08$ & 168 & ESER-EFS \\
\hline Pu-238 & $7.092 \mathrm{E}+08$ & 168 & ESER-ATO \\
\hline Pu-238 & $7.092 \mathrm{E}+08$ & 168 & ESER-MOU \\
\hline Pu-238 & $7.092 \mathrm{E}+08$ & 168 & ESER-BLU \\
\hline Pu-238 & $7.092 \mathrm{E}+08$ & 168 & ESER-TER \\
\hline Pu-238 & $7.092 \mathrm{E}+08$ & 168 & ESER-HOW \\
\hline Pu-238 & $7.092 \mathrm{E}+08$ & 168 & RWMCS \\
\hline Pu-238 & $7.092 \mathrm{E}+08$ & 168 & $\mathrm{MFCN}$ \\
\hline Pu-238 & $7.092 \mathrm{E}+08$ & 168 & MFCGS \\
\hline Pu-238 & $7.092 \mathrm{E}+08$ & 168 & Onsite_station \\
\hline Pu-238 & $7.092 \mathrm{E}+08$ & 168 & Offsitē_Station \\
\hline Pu-239 & $6.447 \mathrm{E}+08$ & 168 & $\mathrm{BEA}-\mathrm{TRA}{ }^{-}$ \\
\hline Pu-239 & $6.447 \mathrm{E}+08$ & 168 & $\mathrm{BEA}-\mathrm{CPP}$ \\
\hline Pu-239 & $6.447 \mathrm{E}+08$ & 168 & BEA-RWMC \\
\hline Pu-239 & $6.447 \mathrm{E}+08$ & 168 & BEA-VAN \\
\hline Pu-239 & $6.447 \mathrm{E}+08$ & 168 & BEA-IRC \\
\hline Pu-239 & $6.447 \mathrm{E}+08$ & 168 & BEA-BLKFT \\
\hline Pu-239 & $6.447 \mathrm{E}+08$ & 168 & BEA-SMC \\
\hline Pu-239 & $6.447 \mathrm{E}+08$ & 168 & BEA-GATE \\
\hline Pu-239 & $6.447 \mathrm{E}+08$ & 168 & BEA-REST \\
\hline Pu-239 & $6.447 \mathrm{E}+08$ & 168 & $\mathrm{BEA}-\mathrm{IF}$ \\
\hline Pu-239 & $6.447 \mathrm{E}+08$ & 168 & $\mathrm{BEA}-\mathrm{NRF}$ \\
\hline Pu-239 & $6.447 \mathrm{E}+08$ & 168 & $\mathrm{BEA}-\mathrm{RTC}$ \\
\hline Pu-239 & $6.447 \mathrm{E}+08$ & 168 & $\mathrm{BEA}-\mathrm{EBR}$ \\
\hline Pu-239 & $6.447 \mathrm{E}+08$ & 168 & BEA-MFC \\
\hline Pu-239 & $6.447 \mathrm{E}+08$ & 168 & BEA-SUGAR \\
\hline Pu-239 & $6.447 \mathrm{E}+08$ & 168 & BEA-INTEC \\
\hline Pu-239 & $6.447 \mathrm{E}+08$ & 168 & $\mathrm{BEA}-\mathrm{CFA}$ \\
\hline Pu-239 & $6.447 \mathrm{E}+08$ & 168 & BEA-EFS \\
\hline Pu-239 & $6.447 \mathrm{E}+08$ & 168 & BEA-CRATER \\
\hline Pu-239 & $6.447 \mathrm{E}+08$ & 168 & ESER-VAN \\
\hline Pu-239 & $6.447 \mathrm{E}+08$ & 168 & ESER-CRA \\
\hline Pu-239 & $6.447 \mathrm{E}+08$ & 168 & ESER-ARC \\
\hline Pu-239 & $6.447 \mathrm{E}+08$ & 168 & ESER-SUG \\
\hline Pu-239 & $6.447 \mathrm{E}+08$ & 168 & ESER-IDA \\
\hline Pu-239 & $6.447 \mathrm{E}+08$ & 168 & ESER-DUB \\
\hline Pu-239 & $6.447 \mathrm{E}+08$ & 168 & ESER-MON \\
\hline Pu-239 & $6.447 \mathrm{E}+08$ & 168 & ESER-EFS \\
\hline Pu-239 & $6.447 \mathrm{E}+08$ & 168 & ESER-ATO \\
\hline Pu-239 & $6.447 \mathrm{E}+08$ & 168 & ESER-MOU \\
\hline Pu-239 & $6.447 \mathrm{E}+08$ & 168 & ESER-BLU \\
\hline Pu-239 & $6.447 \mathrm{E}+08$ & 168 & ESER-TER \\
\hline Pu-239 & $6.447 \mathrm{E}+08$ & 168 & ESER-HOW \\
\hline Pu-239 & $6.447 \mathrm{E}+08$ & 168 & RWMCS \\
\hline Pu-239 & $6.447 \mathrm{E}+08$ & 168 & $\mathrm{MFCN}$ \\
\hline Pu-239 & $6.447 \mathrm{E}+08$ & 168 & MFCGS \\
\hline Pu-239 & $6.447 \mathrm{E}+08$ & 168 & Onsite_station \\
\hline Pu-239 & $6.447 \mathrm{E}+08$ & 168 & Offsitē_Station \\
\hline $\mathrm{Sr}-90$ & $2.660 \mathrm{E}+10$ & 168 & BEA-TRA \\
\hline $\mathrm{Sr}-90$ & $2.660 \mathrm{E}+10$ & 168 & $\mathrm{BEA}-\mathrm{CPP}$ \\
\hline Sr -90 & $2.660 \mathrm{E}+10$ & 168 & BEA-RWMC \\
\hline $\mathrm{Sr}-90$ & $2.660 \mathrm{E}+10$ & 168 & BEA-VAN \\
\hline $\mathrm{Sr}-90$ & $2.660 \mathrm{E}+10$ & 168 & $\mathrm{BEA}-\mathrm{IRC}$ \\
\hline $\mathrm{Sr}-90$ & $2.660 \mathrm{E}+10$ & 168 & BEA-BLKFT \\
\hline Sr -90 & $2.660 \mathrm{E}+10$ & 168 & BEA-SMC \\
\hline Sr-90 & $2.660 \mathrm{E}+10$ & 168 & BEA-GATE \\
\hline Sr -90 & $2.660 \mathrm{E}+10$ & 168 & $\mathrm{BEA}-\mathrm{REST}$ \\
\hline Sr -90 & $2.660 \mathrm{E}+10$ & 168 & $\mathrm{BEA}-\mathrm{IF}$ \\
\hline Sr -90 & $2.660 \mathrm{E}+10$ & 168 & BEA-NRF \\
\hline Sr -90 & $2.660 \mathrm{E}+10$ & 168 & BEA-RTC \\
\hline $\mathrm{Sr}-90$ & $2.660 \mathrm{E}+10$ & 168 & $\mathrm{BEA}-\mathrm{EBR}$ \\
\hline $\mathrm{Sr}-90$ & $2.660 \mathrm{E}+10$ & 168 & $\mathrm{BEA}-\mathrm{MFC}$ \\
\hline $\mathrm{Sr}-90$ & $2.660 \mathrm{E}+10$ & 168 & BEA-SUGAR \\
\hline Sr -90 & $2.660 \mathrm{E}+10$ & 168 & BEA-INTEC \\
\hline Sr -90 & $2.660 \mathrm{E}+10$ & 168 & $\mathrm{BEA}-\mathrm{CFA}$ \\
\hline $\mathrm{Sr}-90$ & $2.660 \mathrm{E}+10$ & 168 & BEA-EFS \\
\hline $\mathrm{Sr}-90$ & $2.660 \mathrm{E}+10$ & 168 & BEA-CRATER \\
\hline Sr -90 & $2.660 \mathrm{E}+10$ & 168 & ESER-VAN \\
\hline Sr -90 & $2.660 \mathrm{E}+10$ & 168 & ESER-CRA \\
\hline $\mathrm{Sr}-90$ & $2.660 \mathrm{E}+10$ & 168 & ESER-ARC \\
\hline $\mathrm{Sr}-90$ & $2.660 \mathrm{E}+10$ & 168 & ESER-SUG \\
\hline Sr -90 & $2.660 \mathrm{E}+10$ & 168 & ESER-IDA \\
\hline $\mathrm{Sr}-90$ & $2.660 \mathrm{E}+10$ & 168 & ESER-DUB \\
\hline $\mathrm{Sr}-90$ & $2.660 \mathrm{E}+10$ & 168 & ESER-MON \\
\hline
\end{tabular}




\begin{tabular}{|c|c|c|c|c|c|}
\hline $\mathrm{Sr}-90$ & $2.660 \mathrm{E}+10$ & 168 & ESER-EFS & $8.152 \mathrm{E}-01$ & \\
\hline $\mathrm{Sr}-90$ & $2.660 \mathrm{E}+10$ & 168 & ESER-ATO & $1.839 \mathrm{E}-02$ & \\
\hline $\mathrm{Sr}-90$ & $2.660 \mathrm{E}+10$ & 168 & ESER-MOU & $1.397 \mathrm{E}-02$ & \\
\hline $\operatorname{Sr}-90$ & $2.660 \mathrm{E}+10$ & 168 & ESER-BLU & $1.057 \mathrm{E}-01$ & \\
\hline $\mathrm{Sr}-90$ & $2.660 \mathrm{E}+10$ & 168 & ESER-TER & $3.655 \mathrm{E}-02$ & \\
\hline $\mathrm{Sr}-90$ & $2.660 \mathrm{E}+10$ & 168 & ESER-HOW & $2.838 \mathrm{E}-01$ & \\
\hline $\mathrm{Sr}-90$ & $2.660 \mathrm{E}+10$ & 168 & RWMCS & $7.166 \mathrm{E}-01$ & \\
\hline $\mathrm{Sr}-90$ & $2.660 \mathrm{E}+10$ & 168 & $\mathrm{MFCN}$ & $0.000 \mathrm{E}+00$ & \\
\hline $\mathrm{Sr}-90$ & $2.660 \mathrm{E}+10$ & 168 & MFCGS & $0.000 \mathrm{E}+00$ & \\
\hline $\mathrm{Sr}-90$ & $2.660 \mathrm{E}+10$ & 168 & Onsite Station & $1.000 \mathrm{E}+00$ & $3.166 \mathrm{E}-01$ \\
\hline $\mathrm{Sr}-90$ & $2.660 \mathrm{E}+10$ & 168 & Offsité_station & $0.000 \mathrm{E}+00$ & $0.000 \mathrm{E}+00$ \\
\hline I-131 & $1.773 \mathrm{E}+11$ & 168 & BEA-TRA & $9.859 \mathrm{E}-01$ & \\
\hline$I-131$ & $1.773 \mathrm{E}+11$ & 168 & $\mathrm{BEA}-\mathrm{CPP}$ & $9.725 \mathrm{E}-01$ & \\
\hline I-131 & $1.773 \mathrm{E}+11$ & 168 & BEA-RWMC & $9.547 \mathrm{E}-01$ & \\
\hline$I-131$ & $1.773 \mathrm{E}+11$ & 168 & BEA-VAN & $9.597 \mathrm{E}-01$ & \\
\hline$I-131$ & $1.773 \mathrm{E}+11$ & 168 & $B E A-I R C$ & $1.665 \mathrm{E}-01$ & \\
\hline I-131 & $1.773 \mathrm{E}+11$ & 168 & BEA-BLKFT & $2.236 \mathrm{E}-01$ & \\
\hline I-131 & $1.773 \mathrm{E}+11$ & 168 & BEA-SMC & $8.256 \mathrm{E}-01$ & \\
\hline I-131 & $1.773 \mathrm{E}+11$ & 168 & BEA-GATE & $9.225 \mathrm{E}-01$ & \\
\hline $\mathrm{I}-131$ & $1.773 \mathrm{E}+11$ & 168 & BEA-REST & $9.753 \mathrm{E}-01$ & \\
\hline I-131 & $1.773 \mathrm{E}+11$ & 168 & $\mathrm{BEA}-\mathrm{IF}$ & $1.654 \mathrm{E}-01$ & \\
\hline$I-131$ & $1.773 \mathrm{E}+11$ & 168 & $\mathrm{BEA}-\mathrm{NRF}$ & $9.992 \mathrm{E}-01$ & \\
\hline I-131 & $1.773 \mathrm{E}+11$ & 168 & $\mathrm{BEA}-\mathrm{RTC}$ & $9.973 \mathrm{E}-01$ & \\
\hline I-131 & $1.773 \mathrm{E}+11$ & 168 & $\mathrm{BEA}-\mathrm{EBR}$ & $9.562 \mathrm{E}-01$ & \\
\hline I-131 & $1.773 \mathrm{E}+11$ & 168 & BEA-MFC & $5.164 \mathrm{E}-01$ & \\
\hline I-131 & $1.773 \mathrm{E}+11$ & 168 & BEA-SUGAR & $2.115 \mathrm{E}-01$ & \\
\hline I-131 & $1.773 \mathrm{E}+11$ & 168 & BEA-INTEC & $9.788 \mathrm{E}-01$ & \\
\hline$I-131$ & $1.773 \mathrm{E}+11$ & 168 & $\mathrm{BEA}-\mathrm{CFA}$ & $9.250 \mathrm{E}-01$ & \\
\hline I-131 & $1.773 \mathrm{E}+11$ & 168 & BEA-EFS & $9.915 \mathrm{E}-01$ & \\
\hline I-131 & $1.773 \mathrm{E}+11$ & 168 & BEA-CRATER & $2.794 \mathrm{E}-01$ & \\
\hline I-131 & $1.773 \mathrm{E}+11$ & 168 & ESER-VAN & $9.597 \mathrm{E}-01$ & \\
\hline I-131 & $1.773 \mathrm{E}+11$ & 168 & ESER-CRA & $2.794 \mathrm{E}-01$ & \\
\hline I-131 & $1.773 \mathrm{E}+11$ & 168 & ESER-ARC & $4.859 \mathrm{E}-01$ & \\
\hline$I-131$ & $1.773 \mathrm{E}+11$ & 168 & ESER-SUG & $2.115 \mathrm{E}-01$ & \\
\hline I-131 & $1.773 \mathrm{E}+11$ & 168 & ESER-IDA & $1.654 \mathrm{E}-01$ & \\
\hline$I-131$ & $1.773 \mathrm{E}+11$ & 168 & ESER-DUB & $5.269 \mathrm{E}-01$ & \\
\hline I-131 & $1.773 \mathrm{E}+11$ & 168 & ESER-MON & $7.014 \mathrm{E}-01$ & \\
\hline I-131 & $1.773 \mathrm{E}+11$ & 168 & ESER-EFS & $9.915 \mathrm{E}-01$ & \\
\hline$I-131$ & $1.773 \mathrm{E}+11$ & 168 & ESER-ATO & $6.536 \mathrm{E}-01$ & \\
\hline I-131 & $1.773 \mathrm{E}+11$ & 168 & ESER-MOU & $2.237 \mathrm{E}-01$ & \\
\hline$I-131$ & $1.773 \mathrm{E}+11$ & 168 & ESER-BLU & $4.651 \mathrm{E}-01$ & \\
\hline I-131 & $1.773 \mathrm{E}+11$ & 168 & ESER-TER & $8.216 \mathrm{E}-01$ & \\
\hline I-131 & $1.773 \mathrm{E}+11$ & 168 & ESER-HOW & $7.774 \mathrm{E}-01$ & \\
\hline I-131 & $1.773 \mathrm{E}+11$ & 168 & RWMCS & $9.537 \mathrm{E}-01$ & \\
\hline I-131 & $1.773 \mathrm{E}+11$ & 168 & $\mathrm{MFCN}$ & $5.514 \mathrm{E}-01$ & \\
\hline$I-131$ & $1.773 \mathrm{E}+11$ & 168 & MFCGS & $5.254 \mathrm{E}-01$ & \\
\hline$I-131$ & $1.773 \mathrm{E}+11$ & 168 & Onsite Station & $1.000 \mathrm{E}+00$ & $6.657 \mathrm{E}-01$ \\
\hline$I-131$ & $1.773 \mathrm{E}+11$ & 168 & Offsite Station & $0.000 \mathrm{E}+00$ & $0.000 \mathrm{E}+00$ \\
\hline
\end{tabular}

